\title{
UNA LEGUA CUADRADA: EXPLORING THE HISTORY OF SWANTON PACIFIC RANCH AND ENVIRONS
}

\author{
A Thesis \\ presented to \\ the Faculty of California Polytechnic State University, \\ San Luis Obispo
}

\author{
In Partial Fulfillment \\ of the Requirements for the Degree \\ Master of Arts in History \\ by \\ Jeanine Marie Scaramozzino \\ December 2015
}




\section{(C) 2015}

Jeanine Marie Scaramozzino

ALL RIGHTS RESERVED 
TITLE:

AUTHOR:

DATE SUBMITTED:

COMMITTEE CHAIR:

COMMITTEE MEMBER:

COMMITTEE MEMBER:

COMMITTEE MEMBER:
Una Legua Cuadrada: Exploring the History of Swanton Pacific Ranch and Environs

Jeanine Marie Scaramozzino

December 2015

Joel Orth, Ph.D.

Associate Professor of History

Paul Hiltpold, Ph.D.

Professor of History

Matthew Hopper, Ph.D.

Associate Professor of History

Kathleen Murphy, Ph.D.

Associate Professor of History

and Graduate Student Coordinator 


\begin{abstract}
Una Legua Cuadrada: Exploring the History of Swanton Pacific Ranch and Environs Jeanine Marie Scaramozzino
\end{abstract}

Swanton Pacific Ranch is an educational and research facility owned by the Cal Poly Corporation and managed by the Cal Poly State University (Cal Poly) College of Agriculture, Food and Environmental Sciences. Located about 180 miles north of campus and just 14 miles north of Santa Cruz, California on Highway 1, the property was first leased to and then donated to Cal Poly by the late Albert E. Smith in 1993. The rancho's original inhabitants included Native Americans, Spaniards, Mexicans, as well as various European immigrants and their descendants; currently, the staff, faculty, and students of Cal Poly occupy the land. Each of these groups used the land's rich environment for a variety of purposes from subsistence to financial and intellectual pursuits. Over time, researchers and local historians have discussed specific aspects of the Swanton Pacific Ranch and its environs, particularly concerning its occupants, land use (e.g. businesses, farming, research), and land features (e.g. geology, botany). The following work offers a more cohesive, descriptive narrative of the land and its people organized chronologically from prehistory to the present.

Keywords: Swanton Pacific Ranch, Rancho Agua Puerca y las Trancas, Cal Poly 


\section{ACKNOWLEDGMENTS}

There are so many people I would like to thank for supporting me during the more than four-year process of completing this thesis and my degree, but I cannot list them all. Here I will acknowledge a few individuals who deserve special mention. I would especially like to acknowledge the direction, suggestions, encouragement, and patience of my advisor, Dr. Joel Orth. His graduate course in environmental history was the inspiration for this research. I also would like to thank all my professors for their knowledge-sharing, particularly my committee members, Dr. Paul Hiltpold and Dr. Matthew Hopper, for their comments on this manuscript. As well, I would like to thank Dr. Kathleen Murphy, History Department Graduate Student Coordinator.

Russell White introduced me to Swanton Pacific Ranch (SPR) in December 2013. His knowledge of the property and his personal contacts provided me the opportunity to start research on the Ranch. His continued support of this project cannot be overemphasized. Along with Russ, this project would have never gone forward without Brian Dietterick, Natural Resources Management and Environmental Science Professor and Ranch Director; his continuous assistance and exceptional backing kept me going. I am indebted, as well, to the Swanton Pacific Ranch students, staff, and faculty, especially Cortney Newby, Steve Auten, Gordon Claassen, Nick Macias, and lan Kapostins. The support of Anna Gold, Dean of Library Services, and my colleagues Brett Bodemer, Dana Ospina, Catherine Trujillo, Patrick Kammermeyer, Conny Liegl, and Cameron Anvari was equally invaluable.

In addition to friends and colleagues, I am grateful to the many Swanton Pacific Railroad Society (SPRS) members and affiliates who have supported this work from my first visit to the Ranch, including Chris Taylor; Randy Jones; Marianne Carnegie; Ed Carnegie, SPRS Director; and Lou Haughney, SPRS Historian. Current and past Swanton residents and researchers Bud and Noreen McCrary, Lud and Barbara McCrary, Ben and Jan Wilson, and Roberta Smith also have participated in this project by informing my work. Jim West has provided extensive information by responding with alacrity to emails and requests to speak with me. Former Swanton resident Marie Pini Stoner shared her family's story by sitting down with me for an oral history interview and allowing me to share her photographs with others. Her son, Kim Stoner, was instrumental in connecting me with his mother and providing property land lease information from the first land titles to the present in addition to other important information.

I would like to thank the staff, faculty, and volunteers at the University of California Santa Cruz and the Santa Cruz Museum of Art and History who provided me with resources and context on a variety of historical topics. I would like, also, to acknowledge the time and effort Steven Auten took to read every word of this document to provide comments and clarification, and Dawn Janke's work copyediting of this manuscript. 
I especially want to thank all the people who provided me content that is not contained within this thesis. I had to stop gathering information so I could finish my degree, but your information is incredibly valuable and will be shared in subsequent manuscripts.

Only with the support of my loved ones has this thesis been completed: my parents, James and Marie Scaramozzino; sisters, Nicole Brophy and Colette Morin; my in-laws, Gary and Deborah Blank; and my close friends. Finally, most critical has been my husband Jason Blank's love, patience, unwavering commitment, and support through the long road to the completion of this degree. 
Note to Readers: Reasonable effort was made to accurately and fairly describe and attribute the content within this thesis. However, as all historical research sources can provide conflicting information, the passing down of stories can result in different versions of the facts, and what is considered common knowledge becomes murky. If you can provide clarification on an issue, or have any concerns or comments about the contents of this research, please contact the author at jscaramo@calpoly.edu. 


\section{TABLE OF CONTENTS}

Page

LIST OF TABLES $\quad \mathrm{X}$

LIST OF FIGURES

INTRODUCTION: PEOPLE AND THE LAND 1

CHAPTER 1: PRE-DISCOVERED CALIFORNIA, THE SPANISH, AND

MEXICAN LAND GRANTS $\quad 7$

Ohlone $\quad 7$

Economics and Trade Routes: Prehistoric Exchange Systems in

California 13

Land Management 19

Coastal Ohlone Dietary Resources and Missionization 22

Mexican Land Grants $\quad 27$

CHAPTER 2: SWANTON (1800-1950) 32

Introduction 32

Deconstructing Al Smith's 1990 Interview - Rancho Era to Swanton Era (1800-1940s) 34

Is it Scott's Creek or Scott Creek or Scotts Creek? 42

Viewing Land Use Through Imagery $\quad 54$

CHAPTER 3: ALBERT B. SMITH (1950-1993) 65

Education $\quad 68$

$\begin{array}{ll}\text { Orchard Supply Hardware } & 71\end{array}$

Swanton Pacific Ranch $\quad 73$

Swanton Pacific Railroad $\quad 75$

$\begin{array}{ll}\text { Cal Poly State University } & 78\end{array}$

CHAPTER 4: THE ARTISTIC AND INTELLECTUAL BIOGRAPHY OF SWANTON (1950-PRESENT) 81

Artistic Biography $\quad 82$

Robert Sudlow (1940s-1990s) 82

Big Creek Pottery (1960s-1980s) 82

William Everson (1970s-1990s) $\quad 85$

Intellectual Biography $\quad 86$

University of California, Berkeley 86

Cal Poly Scholarship and Learn by Doing $\quad 87$

James West $\quad 90$ 
$\begin{array}{ll}\text { AFTERWARD } & 96\end{array}$

$\begin{array}{ll}\text { BIBLIOGRAPHY } & 97\end{array}$

APPENDICES

Appendix A: The Seaside School in Photographs 108

Appendix B: Pini Ranch and Family 116

Appendix C: Orchard Supply Hardware's Inception $\quad 125$

Appendix D: Swanton Pacific Railroad Timeline 128

Appendix E: School of Agriculture Work Day 1991 Agenda 133

Appendix F: Student Use of Swanton Pacific Ranch - 1997-98 College Year Summary

Appendix G: Swanton Pacific Ranch Internship Information Packet $1998 \quad 137$

Appendix H: The Cal Barn: 100 Years of Universities in the Coastal Region of Northern Santa Cruz County

Appendix I: Cal Poly and Swanton Research Projects and Reports Index 144

Appendix J: Swanton 3 Miles 


\section{LIST OF TABLES}

Table

Page

1: Coastal Ohlone Dietary Resources 22

2: Scott's/Scotts/Scott Creek

3: Swanton Pacific Ranch Historical Aerial Imagery 57

4: Swanton Research List 145 


\section{LIST OF FIGURES}

Figure

Page

1: Major Tribes of Central and Northern California

2: Native Tribes, Groups, Language Families and Dialects of California in 1770

3: Indian Trails of Aboriginal California

4: Trade Relations in Aboriginal California

5: Hand Drawn Map of Diseño del Rancho Agua Puerca y las Trancas: Santa Cruz County, California

6: Traverse Line Run from Redmond Post A.P.5 to Large White Post A.P.6. U.S. Coast Survey

7: Ocean Shore Railroad

8: Scott Creek Beach

9: General Land Office Records (GLO) Rancho Agua y Las Trancas Plat Map, 45 1868

10: Map Santa Cruz County, 1880-81

11: Rancho Agua Puerca y las Trancas Eastern Boundary, Sheet 31, Map Santa Cruz County 1880-81

12: Official Map of Santa Cruz County, 1889, Tile Index

13: Official Map of Santa Cruz County, 1889, Tile 9

14: United States Geological Service (USGS), 1902, Santa Cruz Quadrangle

15: Official Map of the County of Santa Cruz, 1906

16: Official Map of the County of Santa Cruz, 1906, Sheet 4 Magnified

17: United States Geological Service (USGS), The National Map, May 17, 2012, USBG 10S EG 6912006 
18: 1928 Swanton Aerial Imagery

19: 1928 and 1941 Aerial Swanton Imagery

20: 1943 Swanton Aerial Imagery

21: 1953 Swanton Aerial Imagery

22: 1956 Swanton Aerial Imagery

62

23: 1975 and 2014 Swanton Aerial Imagery

63

24: Al Smith Portrait, 1938

67

25: Al Smith's Cal Poly Student Identification Card

69

26: Al Smith, Orchard Supply Hardware Portrait, circa 1970

72

27: Al Smith on a Southern Pacific Caboose

73

28: Al Smith, Strawberry Shack, Swanton Pacific Ranch, circa 1980

74

29: Al Smith's Parents at The Panama-California Exposition

77

30: Seaside School, circa 1920

109

31: Seaside School, 1939

32: Seaside School Second Grade Class Photo, 1937

33: Seaside School Class Photo, n.d.

34: Seaside School, n.d.

35: Seaside School, n.d.

36: Seaside School, n.d.

37: Seaside School, August 31, 2014, Marie Pini Stoner

38: Pini Box Camera

39: The Artichoke Pioneers, 1924 
40: Pini Ranch, 1929

41: Trumpet Plant, Siberia, Swanton Pacific Ranch

42: Pini Family Easter, 1952

43: Pini Ranch Lease

124

44: OSH Co-op Certificate

126

45: The Swanton Pacific Locomotive Tender

128

46: Postcard 1962 


\section{INTRODUCTION: PEOPLE AND THE LAND}

Una Legua Cuadrada refers to the traditional Spanish unit of area equal to one square (legua) league, roughly 4,340.28 acres. ${ }^{1}$ Agua Puerca y las Trancas was a one square league rancho that changed in ownership over time, but eventually 3,200 acres of the original rancho became Swanton Pacific Ranch, an area about 14 miles north of Santa Cruz, California. ${ }^{2}$ This work explores the history of Swanton Pacific Ranch and environs by researching the inhabitants of the land over time: Native Americans, Spaniards, Mexicans, early Europeans and their ancestors, and the subsequent ownership of much of the original rancho by Albert B. Smith, who bequeathed the land to Cal Poly. To date, there have been no published academic studies investigating the history of Swanton Pacific Ranch in a detailed and holistic manner.

The people and the environment of Swanton Pacific Ranch have found their place in the recorded history of California's farming, mining (limestone), railroading, logging, and ranching industries as well as in the history of Santa Cruz City, Santa Cruz County, and adjacent towns (e.g. Davenport). ${ }^{3}$ The part Swanton plays is ancillary to the history of the founding of the city and county. ${ }^{4}$ Swanton is the place that Fred Swanton, businessman and mayor of Santa Cruz for six years, first dammed a river and built an

\footnotetext{
${ }^{1}$ Jacob Neibert Bowman, "Weights and Measures of Provincial California," California Historical Society Quarterly 30, no.4 (1951): 326.

${ }^{2}$ Rancho Agua Puerca y las Trancas was actually 4,421.52-acres, 81.24 acres larger than a Spanish league per James W. Shanklin, Report of the Surveyor-General of the State of California from August 1st, 1879, to August 1st, 1880 (Sacramento, CA: State of California, Office of Surveyor-General, 1880), 51.

${ }^{3}$ Please refer to the extensive bibliography at the end of thesis, which provides numerous resources that focus on each of these specific topics; related pre-statehood documents can be found at University of California Santa Cruz's Special Collections.

${ }^{4}$ The Santa Cruz Museum of Art and History has published a number of sources about Santa Cruz over the years. They have created an index of these publications, the McPherson Publications Fund Index, based on region and topic. Available online at http://www.santacruzmah.org/wpcontent/uploads/2013/07/McPherson-Fund-Publications-Index1.pdf.
} 
electric power plant to light the city. References to Swanton are primarily in conjunction with resources such as water, lumber, and minerals that supported the local economy, as well as with California infrastructure and research. ${ }^{5}$

This thesis focuses specifically on Swanton Pacific Ranch and environs. The basis of this mosaic-like narrative comes from the collection and review of, among other sources, archival materials, oral histories, undergraduate and graduate projects and theses, dissertations, government documents and projects, legal documents, newspaper articles, industry records, photographs, maps, diaries, ephemera, books (from the 1800s+), and websites. In addition, local residents, historians, and Swanton Pacific Railroad Society members contributed a wealth of knowledge with their own rich paperbased, electronic, and object archives.

History is not static, and this is true of Swanton with its unique evolving story of physical and intellectual production. Swanton is an example of the dynamic and changing relationships between environment and culture, the land shaping people's range of choices, and how this process also reshapes the environment. ${ }^{6}$ Analyzing how people create and recreate their livelihood through the evolving nature of society and ecological processes is critical. ${ }^{7}$ This provides the context in which human history unfolds. ${ }^{8}$

\footnotetext{
${ }^{5}$ The following are examples of prior works that typify these trends: Edward Sanford Harrison, History of Santa Cruz County California (San Francisco, CA: Pacific Press Publishing Company, 1982); Edward Martin, History of Santa Cruz County, California, with Biographical Sketches (Los Angeles, CA: Historic Record Company, 1911, 2014); and Margaret Koch, Santa Cruz County: Parade of the Past. Santa Cruz (CA: Western Tanager Press, 1973, 1991).

${ }^{6}$ William Cronon, Changes in the Land: Indians, Colonists, and the Ecology of New England (New York, NY: Hill and Wang, 1983), 13.

${ }^{7}$ Ibid.

${ }^{8}$ John R. McNeill, "Observations on the Nature and Culture of Environmental History," History and Theory 42, no. 4 (2003): 42.
} 
The inhabitants' relationship to Swanton is a balance between the land's offerings, the influence of the environment on human access to resources, and the effects of humans on the environment. ${ }^{9}$ This is the story of the people who lived, used, and prospered through their complex interactions with the landscape as described through many lenses. The relationships among the people and the land are observable through production, access and use of food, profits of industry and results of intellectual pursuits, and the connections between people.

The Swanton Valley land has a rich physical ecology. People chose to settle this land because it provided certain resources. Inhabitants used the abundance of flora and fauna for housing, subsistence, economic benefits, intellectual activities, and inspiration for artistic expression. Over time, the value of the resources utilized by the inhabitants for their personal use, trade, and cultivation of intellectual interests increased, and the local economy drove that value. Like the story of California, the story of Swanton can be told in terms of its land and the men and women claiming the land in a procession starting with prehistory and culminating in the present moment. ${ }^{10}$

The chronicle of Swanton forms a complex web of interactions that go well beyond people's connections with the physical environment to include the social, intellectual, and industrial environments in which people relate. None of these elements operates independently. Providing a historical view over a significant period of time and focusing on the connections between some of these elements offers additional lenses through

\footnotetext{
9 J. Donald Hughes, "Global Dimensions of Environmental History," Pacific Historical Review 70, no. 1 (2001): 93.

${ }^{10}$ William W. Robinson, Land in California: The Story of Mission Lands, Ranchos, Squatters, Mining Claims, Railroad Grants, Land Scrip, Homesteads (Berkeley, CA: University of California Press, 1948), 1.
} 
which to open up the history of Swanton to a variety of disciplines and approaches. For example, this narrative does not specifically discuss the hydrology of Scott Creek, also called Scotts or Scott's Creek, but someone interested in studying this factor may want to consider how the last few hundred years of people's land practices; grazing, lumbering and industrial uses; and fires continuously reshaped the creek. ${ }^{11}$ This study serves as a reminder to readers that over time a wide range of activities have been at work on the Swanton landscape. The research presented also provides for deeper scholarship and interpretation of these relationships.

While Swanton did play a significant role in Santa Cruz and Central Coast history (i.e. a source of hydroelectric power and timber), a cohesive and detailed history of Swanton does not exist. Historical documentation describes Swanton in various ways that provide some details but there is often missing content between one fact and another. Current residents have many of those details, but they are part of an oral tradition and are not being recorded. There are numerous written records, but unfortunately many repeat the exact same text with no attribution and do not contain details to fill in gaps. The primary source used in most documentation of Swanton Pacific Ranch's "complete" history is an Al Smith interview conducted in July $1990 .{ }^{12}$ In addition, the connections

\footnotetext{
${ }^{11}$ Scott Creek is regularly referred to as Scotts Creek. Smith and the federal and state government use Scott. To be consistent, I will use Scott Creek in this document. If I am quoting someone I will maintain the naming convention they use.

${ }^{12}$ The Albert B. Smith interview by unknown, History of Swanton, July 1990, includes the following sections: Indian Days, Mexican Land Grant, The Beginnings of Swanton, Agriculture, The Swanton Pacific Years, and a Concluding Statement. Available online at http://spranch.calpoly.edu/mission.ldml, the content of this interview will be quoted in the appropriate sections throughout this document. Who conducted the interview and what precipitated it is not completely clear. In the records of the Swanton Pacific Railroad Society, a couple of slightly different "original" typed versions of the interview exist. This leads to speculation that the interview was conducted by a member(s) of the Swanton Pacific Railroad Society. In addition to the integration of the interview's content into this document, the interview provided the basis for
} 
between the inhabitants and between the inhabitants and the variety of environments with which they interact, are not explicitly constructed. It is important to capture, record, and share the 'mortar' (i.e. details) between the 'blocks' of facts. Taking detailed pieces of information from disparate sources, or puzzle pieces, and putting them together creates a more historically complete puzzle. There are still pieces missing. The historical information presented in this narrative provides a chronology of residents and their relationship with the Swanton Valley and the adjacent environs that can be used by other persons to contextualize and situate their own expertise and knowledge. ${ }^{13}$

The major outcome of this Master's thesis research is the discovery of resources that, when viewed as a collection, serve as the foundation for an archive/library of Swanton materials. Another purpose of this study is to provide an extensive bibliography of the Ranch and its environs for use by others for future work in this area. To that end, this manuscript includes examples and ideas for further study.

This thesis begins as a narrative history of the landscape and peoples that have inhabited the Swanton Ranch area and concludes with a discussion and list of resources

the chapter divisions as well as other components. The interview can be seen as a historiography of Swanton Pacific Ranch. Smith's history focuses specifically on his land, not on the surrounding properties or owners, though he does briefly mention the Ocean Shore Railroad and San Vicente Lumber. He discusses the nature of the land in relation to its uses (ex. agriculture). This interview is quoted or paraphrased in almost all Cal Poly documentation and scholarly works when sharing a general historical overview of the Ranch. It is very likely that his interview will continue to be the work most people refer to as it provides a "quick summary" (it is only about two pages) for the Ranch. In the Concluding Statement, Smith stated the following: "I know I have wandered from a straight history of the Swanton Pacific Ranch. It got its name because, somehow, many of my tools were stamped S.P. The brand I selected was the lazy SP. It is by the Pacific, and it is in Swanton. Swanton is an uncrowded, beautiful place. My goal in putting this acreage together is to preserve it as such and to share it now and in the future with people who will appreciate it and profit from the experience. Thanks for listening!".

${ }^{13}$ Please refer to Robinson, 1948, which provides an extensive and detailed history of California Native Americans, including: pre-history, effects of Spanish missions and their secularization, Mexican ranching and cattle grazing rights, the results of the Mexican-American War on the legality of land grants, and land grants to railroads. 
for additional research. Chapter one discusses in detail the Ohlone peoples with an emphasis on how they used the land and their connections to wider trade patterns premissionization. The chapter then discusses the collapse of the Ohlone people during the missionization period and highlights some of the changes that missionization brought in terms of land ownership, subsistence patterns, and land use.

The subsequent chapters provide broad sketches of the years following missionization to the present; for more in-depth discussions of the content, however, there is a rich bibliography that lists numerous resources. These chapters are roughly based on the occupants and land uses over particular time periods. Chapter two recounts the early settlers and beginnings of Swanton from 1800-1950 using specific examples of land use and historiography. The complexity of the change in ownership during this time and the intense economic activities that supported local and national economics is evident, and the chapter provides additional context with which to see how Swanton is more than just a supporting actor in Santa Cruz history. Chapter three provides an overview of Albert E. Smith's life in relation to his acquisition of the property and railroad. Most importantly, the chapter recounts how Smith founded Cal Poly's "living laboratory." The final chapter explores the extensive intellectual and creative activities inspired by Swanton lands. The scholarly and artistic elements of the property are well known by its current inhabitants, many of whom are the descendants of original settlers. There is recognition of these artistic and research elements, though piecemeal, throughout the nation and around the world. This thesis brings together, in one place, information not previously collected into a single document. 
CHAPTER 1: PRE-DISCOVERED CALIFORNIA, THE SPANISH, AND MEXICAN LAND GRANTS

\section{Ohlone}

Archaeologists determined that Native Americans settled the area now known as Santa Cruz, California sometime between 1200 to 5000 years ago. ${ }^{14}$ Ethnologists and anthropologists have consistently characterized indigenous Californian cultures simplistically, ignoring complexities and variation. However, anthropologists have now begun a reassessment of groups such as the Ohlone, who inhabited what is now Santa Cruz, and believe their linguistic complexity and cultural continuity make them unique among the indigenous peoples of the North American continent. ${ }^{15}$ Coastal Ohlone built and lived in settlements in the area and were not seasonally migratory, in part because the resources they needed for subsistence were abundant throughout the seasons in the same location. ${ }^{16}$

The Native Americans that lived from Monterey to San Francisco were first referred to as Costanoan (which is missionization Spanish for "coastal peoples") and later as the Ohlone (possibly in reference to the Olijan Rancho near San Francisco). Please see Figure 1: Major Tribes of Central and Northern California for the historic map depicting locations of major Native American groups in California. Later researchers

\footnotetext{
${ }^{14}$ Sheridan F. Warrick ed. The Natural History of the UC Santa Cruz Campus. Vol. 11, Environmental Field Program, University of California Santa Cruz. (Santa Cruz, CA: University of California Santa Cruz, 1982), 3.; Indigenous Peoples began settling California 13,000-15,000 years ago.

${ }^{15}$ Warrick, 1982, 2.

${ }^{16}$ Refer to William Cronan, Changes in the Land: Indians, Colonists, and the Ecology of New England (New York, NY: Hill and Wang, 1993) and Timothy Silver, A New Face on the Countryside: Indians, Colonists, and Slaves in South Atlantic Forests, 1500-1800 (New York, NY: Cambridge University Press, 1990) for detailed histories regarding Indigenous Peoples and land management.
} 
continued to use Ohlone to refer to the peoples of the area but recognized that this group consisted of numerous nation groups. Scholars have approximated that up to 50 nation groups and language groups made up what is referred to as the Ohlone. Please refer to Figure 2: Native Tribes, Groups, Language Families and Dialects of California in 1770 for additional information on the individual tribes. The descendants of the Indigenous Peoples that inhabited the area now referred to as Swanton identify as Amah Mutsun. ${ }^{17}$ In general, however, academics continue to use Ohlone to describe Indigenous Peoples that lived in the Swanton area. ${ }^{18}$

\footnotetext{
${ }^{17}$ An expert was contacted, out of respect to the Amah Mutsun, to determine the appropriate terminology to use in this document: "The Amah Mutsun Tribal Band can be described as a tribe, Native American, or Indigenous Peoples. Tribal distinctions are now recognized between the Amah Mutsun Tribal Band and the Ohlone/Costanoan Esselen Nation. When referring to the land base of Swanton it is more specifically the ancestral land of the Amah Mutsun." Jenell Rae Navarro, Cal Poly Ethnic Studies Professor, email to author, March 30, 2015. Although the Amah Mutsun are not recognized by the federal government, and all of their ancestral land is privately held or owned by the state or county, they are still a thriving tribe, consisting of about 600 people. The tribal chairperson for the Amah Mutsun is Valentin Lopez. Please refer to the following for additional context: Valentin Lopez, "Healing from Historical Trauma: The Journey of the Amah Mutsun," News from Native California 28, no. 2 (2015): 65-69 and Kara Guzman, "Santa Cruz County Land Trust Restores Native American Stewardship," Santa Cruz Sentinel (Santa Cruz, CA), Nov. 28, 2014.

${ }^{18}$ While the author recognizes that Swanton is the ancestral land of the Amah Mutsun, due to the proliferation of the use of Ohlone in academia, the author chose to use Ohlone within this text. When available, the author specifically pulled out data and text from resources only related to the Native Americans that lived near the area now known as Swanton.
} 


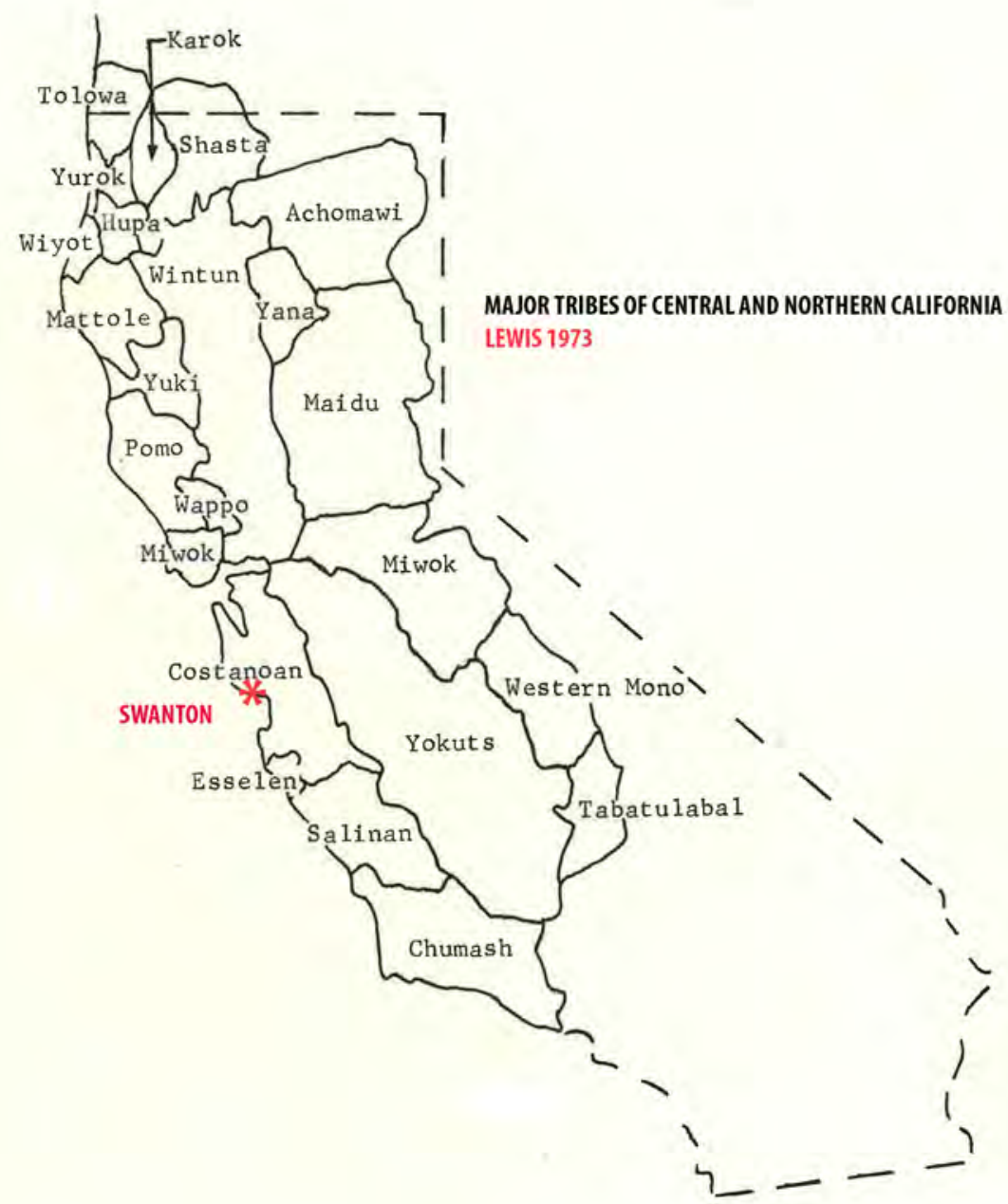

Figure 1: Major Tribes of Central and Northern California. Henry T. Lewis, Patterns of Indian Burning in California: Ecology and Ethnohistory, ed. Lowell John Bean (Ramona, CA: Ballena Press, 1973), 15, provides a map with the previously accepted area populated by the Costanoan (i.e. Ohlone). The red asterisk identifies the location of Swanton. 


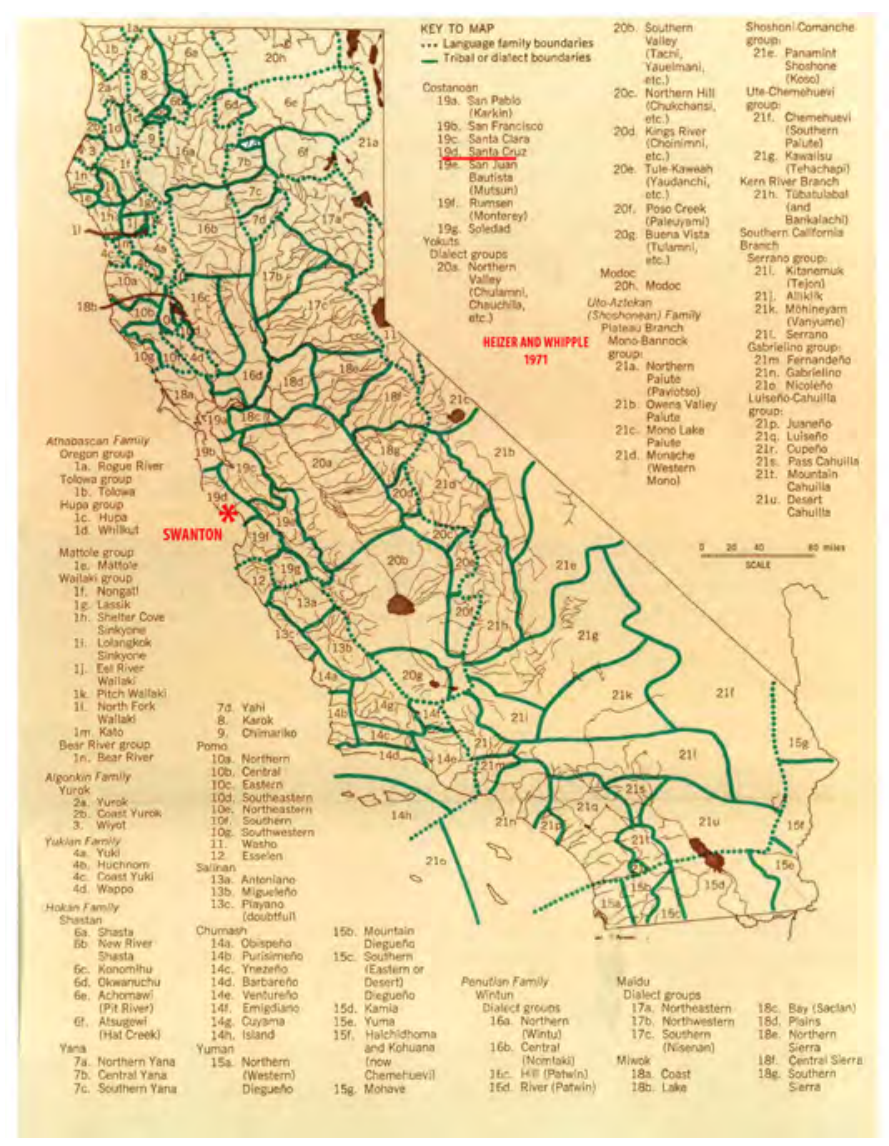

Figure 2: Native Tribes, Groups, Language Families and Dialects of California in 1770. This map is located as a foldout map before the first page in Robert Fleming Heizer and Mary Anne Whipple, eds., The California Indians: A Source Book. Second ed. (Berkeley, CA: University of California Press, 1971). This map outlines the previously accepted area populated by the Costanoan (i.e. Ohlone) and also names and geographically delineates seven distinctive tribes within the group. The red asterisk indicates the location of Swanton and is identified as "19e. Santa Cruz."

The political organization of the Ohlone took the form of a "village community" implying an area of land instead of a settlement. ${ }^{19}$ About 100-250 Ohlone lived in Swanton Valley. The community moved within a small spatial area to exploit different natural resources throughout the year, including Waddell and Scott Creek. The Northwest Information Center (NWIC) of the California Historical Resources Information System is one of nine information centers affiliated with the State of California Office of Historic

\footnotetext{
${ }^{19}$ A. L. Kroeber, "Elements of Culture in Native California," in The California Indians: A Source Book, eds. Robert Fleming Heizer and Mary Anne Whipple (Berkeley, CA: University of California Press, 1971), 25.
} 
Preservation (OHP) in Sacramento. This organization and its experts provide information about and record the locations of archeological sites throughout California. ${ }^{20}$ Their documents discuss the location of Ohlone communities along the interior bayshore and oak woodland valleys, or along the grassland terraces and hills of the open coast. ${ }^{21}$ Experts of California prehistoric archeological sites have stated that, based on cultural materials previously found, Native American villages were usually located near fresh water and food sources such as mussel beds along the coast, ridgelines, and open grasslands surrounding forests but not located deep within forests. The assumption would be that the contents of middens (e.g. small collections of kitchen waste or shell heaps) in Swanton Valley would follow this trend. ${ }^{22}$ There is evidence of shell piles and grinding stones that show Ohlone activity took place in the canyon or valley to the north, Waddell Creek, which runs east and west and has a greater beach area, including areas next to Scott Creek. ${ }^{23}$

\footnotetext{
${ }^{20}$ At this time the author has been unable to acquire a copy of: Katherine Coe, "Rare and Endangered Plants and Animals, Archeological Resources and Property Owners Adjacent to the Swanton Pacific Ranch and Forestry" (senior project, Cal Poly, 1990). However, Cal Poly State University, Swanton Pacific Management Plan. (San Luis Obispo, CA: Cal Poly State University, 2011, 27), available online at http://spranch.calpoly.edu/files/2011SPRManagement\%20Plan_v4_111025.pdf, states: "According to an archeological records search done by Katherine Coe as a senior project in 1990, less than $5 \%$ of Swanton Pacific Ranch has been studied for cultural resources." It is assumed that this document contains a rich list of references that could provide a foundation upon which to expand research in this area.

${ }^{21}$ Rob Q. Cuthrell, Chuck Striplen, Mark G. Hylkema, Kent G. Lightfoot, Terry L. Jones, and Jennifer E. Perry, "A Land of Fire: Anthropogenic Burning on the Central Coast of California," in Contemporary Issues in California Archaeology, eds. Terry L. Jones and Jennifer E. Perry (Walnut Creek, CA: Left Coast Press, 2012), 153.

${ }^{22}$ Ibid.,156.

${ }^{23}$ As noted previously, the transcription of the July 1990 interview with Smith is regularly quoted in newsletters, newspaper articles, and student and research documents. In the section Indian Days he states, "Most of the Indian activity of the Central California Ohlone Tribe took place in the canyon or valley to the north, Waddell Creek, which runs east and west and has a greater beach area. Some evidence such as shell piles and grinding stones, show that the Scott Creek area was visited also." The source of his statements is unclear. In response to Smith's comments, the Swanton Pacific Ranch Operations Manager, Steven Auten remarked: "The California Archaeological Addendum filed as part of the Swanton Pacific Ranch Non-industrial Timber Management Plan was extensive. I would agree that there didn't seem to be
} 
As details of California Native American land stewardship practices have come to the attention of natural resource management agencies, collaborations between archaeologists, ecologists, geomorphologists, and botanists have formed. U.S. Forest Service scientists are acknowledging and employing traditional Native American ecological knowledge to more effectively address contemporary environmental problems (e.g. California drought and wildfires). ${ }^{24}$ The University of California Berkeley, the University of California Santa Cruz, the San Francisco Estuary Institute, and the Amah Mutsun Tribal Band (AMTB) have formed an organization whose mission includes consultation with government agencies. ${ }^{25}$

too extensive an occupation in the forested area that we could identify. I would always hear the common sense perspective from others that there were bears in the forest, or that you can't see your enemies coming from very far away in the forest. One questionable site exists up in Little Creek in the sandstone that may show evidence of mortars, but they're not very deep (suggesting a more limited use of years). Maybe this was just part of a hunting camp that they visited in the forest when the acorns were dropping and the deer were in the rut. Good time to catch a timber buck... Many sites occur close to the watercourse in Scotts Creek and many of those are in the forest. It was likely a wide flood plain that you could travel on under the forest canopy and probably had lots of good hunter-gatherer opportunities along its lower stretch. Most certainly from Bettincourt Gulch down (located on Big Creek Lumber Company land a mile or so up from Seaside School House). In addition, more research needs to be completed on the rangeland; it is rich. There have been several sites identified (not recorded) on the rangeland and a few of them, in my opinion and others', were probably significant in size. Hard to put a number on it, but many families to say the least. We maintain specific protections over them because we know where they are, but they're waiting for the right Cal Poly graduate student who wants to record them...I'm not sure why Al would have said the majority of the Native American activity was to the north, didn't ever meet him. Based on food, water, and shelter. I can think of a better place to be. I think the folks who started to show up in the 1800's thought the same thing." Personal communication, to author from Steve Auten, October 24, 2015.

${ }^{24}$ Kent G. Lightfoot and Otis Parrish, California Indians and Their Environment: An Introduction (California Natural History Guide) (Berkeley, CA: University of California Press, 2009), 97; Lightfoot and Parrish, 120, "Increasingly, archaeologists also recognize the mutual benefits of active collaboration with modern descendant communities. Ethnohistoric and ethnographic accounts of indigenous burning practices are important, but the critical cultural knowledge and experience that exist in modern tribal communities can also add valuable new perspectives to collaborative investigations."

${ }^{25}$ R. Flores, "Amah Mutsun Relearning Program: Cultivating Native Wisdom" https://www.google.com/search?client=safari\&rls=en\&q=obsidian\&ie=UTF-8\&oe=UTF-8isdom - for the future generations," University of California Santa Cruz Arboretum, 2014, http://arboretum.ucsc.edu/education/relearning-program/index.html. 
Economics and Trade Routes: Prehistoric Exchange Systems in California

Native Americans that lived at Swanton connected with other Indigenous Peoples within the area we now call California. Davis (1961) studied their trade routes across the state. ${ }^{26}$ There is no definitive set of archaeological or ethnological criteria from which to demarcate California, but based on current borders little archaeological study has been conducted within the San Joaquin Valley, South Coast Ranges, northern Sacramento Valley, northern Sierra Nevada/Cascade ranges, and northwestern California, while other areas have been intensively studied, like the San Francisco Bay and the Southern Coast. $^{27}$

Sample (1950) and Davis (1961) provide the most extensive information about the inter- and intra-tribal economic trade routes of the Indigenous Peoples of California. ${ }^{28}$ During different periods of time, localized trade and exchange over long distances varied greatly based on the development of societies and the development of multilayered exchange systems. ${ }^{29}$ Goods were usually exchanged between groups with a common border or by geographical middlemen, and thus local differences in availability and preferences dictated trade. ${ }^{30}$

\footnotetext{
${ }^{26}$ James Thomas Davis, Trade Routes and Economic Exchange Among the Indians of California (Berkeley, CA: University of California Archaeological Survey, 1961).

${ }^{27}$ Thomas L. Jackson and Jonathon E. Ericson, "Prehistoric Exchange Systems in California," in Prehistoric Exchange Systems in North America, eds. Timothy G. Baugh and Jonathon E. Ericson (New York, NY: Plenum Press, 1994), 385.

${ }^{28}$ L. L. Sample, Trade and Trails in Aboriginal California (Berkeley, CA: University of California Archaeological Survey, 1950); Davis, 1961.

29 Jackson and Ericson, 387, 410.

${ }^{30}$ Davis, 1961, 9, 11.
} 
Davis (1961) presents a substantial literature review of the archeological work regarding the preference for and trade of materials in California and the Southwest. ${ }^{31}$ It is likely that the products of Indigenous Peoples living on the coast were of less value than those provided by the interior Native Americans. ${ }^{32}$ The east-west trade was probably more important than the north-south trade due to the ecological and environmental differences between the coast, coast range, interior valley, and Sierras. ${ }^{33}$ Resource enhancement or restriction was due to exchange systems and economic relations; these were extremely dynamic and partially based on population movements, cultural groups, rapid population growth, intensification of the hunter-gatherer economies, environmental change, and the development of sociopolitical hierarchies. ${ }^{34}$

Trade usually came in the form of the exchange of goods of similar value or the purchase of commodities based on the length of clam shell disc beads. ${ }^{35}$ However, there were also less common methods of acquiring goods including: free reciprocal use of resources; long-term leasing of land; payment to use land for one-time hunting, fishing, or gathering; and informal exchange of gifts with implied reciprocity at a later time. ${ }^{36}$

The Central California Exchange System, specifically the California-Great Basin Exchange System, was the most widespread. Based on artifact distributions, the intensive conveyance of Pacific coast shell beads, ornaments, and obsidian occurred during an early period of prehistoric time, with the least volume happening just prior to

\footnotetext{
${ }^{31}$ Davis, 1961.

${ }^{32}$ Sample, 1950, 4.

${ }^{3}$ Ibid., 5.

${ }^{34}$ Jackson and Ericson, 1994, 387, 409.

${ }^{35}$ Davis, $1961,8$.

${ }^{36} \mathrm{Ibid}$.
} 
contact with Europeans. This exchange is a multivariate phenomenon. ${ }^{37}$ Based on distribution of materials, various transmission routes of obsidian and shell appear to have employed different conveyance systems and sociocultural unity. ${ }^{38}$ With the changing patterns of exchange of these materials, a mosaic emerges based on time period, site function, and artifact class instead of ethnographic records. ${ }^{39}$ There was extensive trading of a distinctive variety of central California coast chert and obsidian from the Pacific coast to Sierra Nevada. ${ }^{40}$

The Ohlone traded mussels, salt, abalone shells, and dried abalone with the Plains Miwok, Sierra Miwork and the Yokuts. ${ }^{41}$ The Ohlone territory also had chert, which, like obsidian, flaked easily into thin slices of rock with sharp edges to make tools such as knives or arrow points. This made it an excellent item for the Ohlone people to use in trade for things they required. ${ }^{42}$ The cinnabar used to make red body paint that the Ohlone mined on their land was of value to nearby Indigenous Peoples. ${ }^{43}$ Unfortunately, the only known import of the Ohlone was piñon Coastal nuts from the Yokuts. ${ }^{44}$

\footnotetext{
${ }^{37}$ Hughes, 2001, 377.

${ }^{38}$ Ibid.

${ }^{39}$ Ibid.

40 Jackson and Ericson, 1994, 393, 397. "I know of three pieces of obsidian found on the property and they have been identified as coming from Lake County by Cal Fire State Archaeologists." Personal communication, to author from Steve Auten, October 24, 2015.

${ }^{41}$ Sample, 1950, 20; Davis, 1961, 19.

${ }^{42}$ Mary Null Boulé, Ohlone Tribe: California Native American Tribes (Vashon, WA: Merryant Publishers, 1992), 33.

${ }^{43}$ Ibid., 33-34.

44 Davis, 1961,19; Richard Levy, "Costanoan," in Handbook of North American Indians 8, ed. Robert Fleming Heizer (Washington, DC: Smithsonian Institution, 1978): 488; Donald Culross Peattie, A Natural History of Western Trees (Boston, MA: Houghton Mifflin, 1953), 65-66 states that piñon nuts are a very particular type of pine tree nuts. These nuts are from Mexican Pinyon Pine (Pinus cembroides) (a.k.a Three-leaved or Stoneseed Pinyon Pine). It is important to note that this is the only known import. Identifying other Ohlone imports is a rich area for additional anthropological and archeological work.
} 
Though raw material trade was important, trade in manufactured goods was key, because the value of the item lay in the expertise and labor involved in its creation. ${ }^{45}$ The Miwok valued olivella shells from a small predatory sea snail in Ohlone territory. The Ohlone did not so much trade olivella shells with the Miwok as allow them to make journeys to their lands to collect the shells. ${ }^{46}$ Generally, instead, the Ohlone more likely traded food items, especially salt, to other groups ${ }^{47}$ The presence of European traders and associated goods may have stimulated trade, but circumstances point to this being a late development. ${ }^{48}$ Many of these original trade routes were later translated to modern routes of trade (Figure 3: Indian Trails of Aboriginal California). ${ }^{49}$ Trading relationships near the Santa Cruz hills and the Monterey Bay area correlate with populations of Indigenous Peoples living in the areas (Figure 4: Trade Relations in Aboriginal California).

\footnotetext{
${ }^{45}$ Sample,1950, 5.

${ }^{46}$ Sample,1950, 17; Davis 1961, 19.

${ }^{47}$ Davis, 1961, 19.

${ }^{48}$ Sample, 1950, 1.

${ }^{49}$ Davis, 1961, 70.
} 


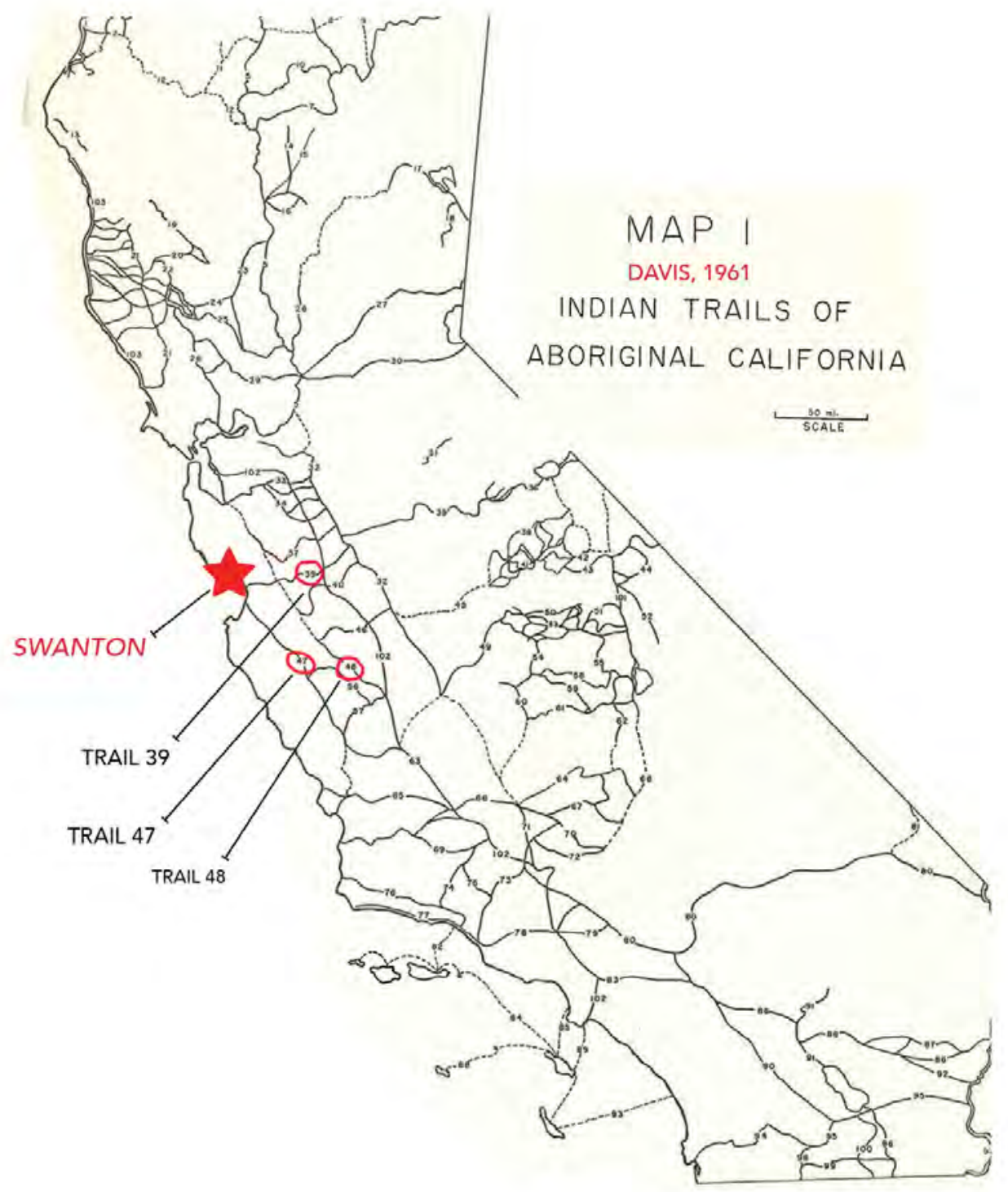

Figure 3: Indian Trails of Aboriginal California. The closest east-west trade route, number 39, originating mid-Monterey Bay, forty-five miles south of Davenport and Swanton Valley, was not accessible for geographic reasons (i.e. mountains). Instead, it is assumed that the closest south routes, number 47 and 48 , were used by the Ohlone. The correlation of these trails with modern thoroughfares can roughly be inferred. Trail number 39 correlates with State Highway 152 from Gilroy east to Fairmead. Trail 47, along with trails 21 and 77, correlate with U.S. Highway 101 from the Oregon border south to Loleta; from Longvale south to Windsor; from San Jose south to Gilroy; from Salinas south to Paso Robles; from Gaviota south to Ventura. Trail 48 correlates with State Highway 25 from Hollister south to junction with State Highway 198, thence east to Coalinga (Davis, 1961, 47). Modified from the original. 


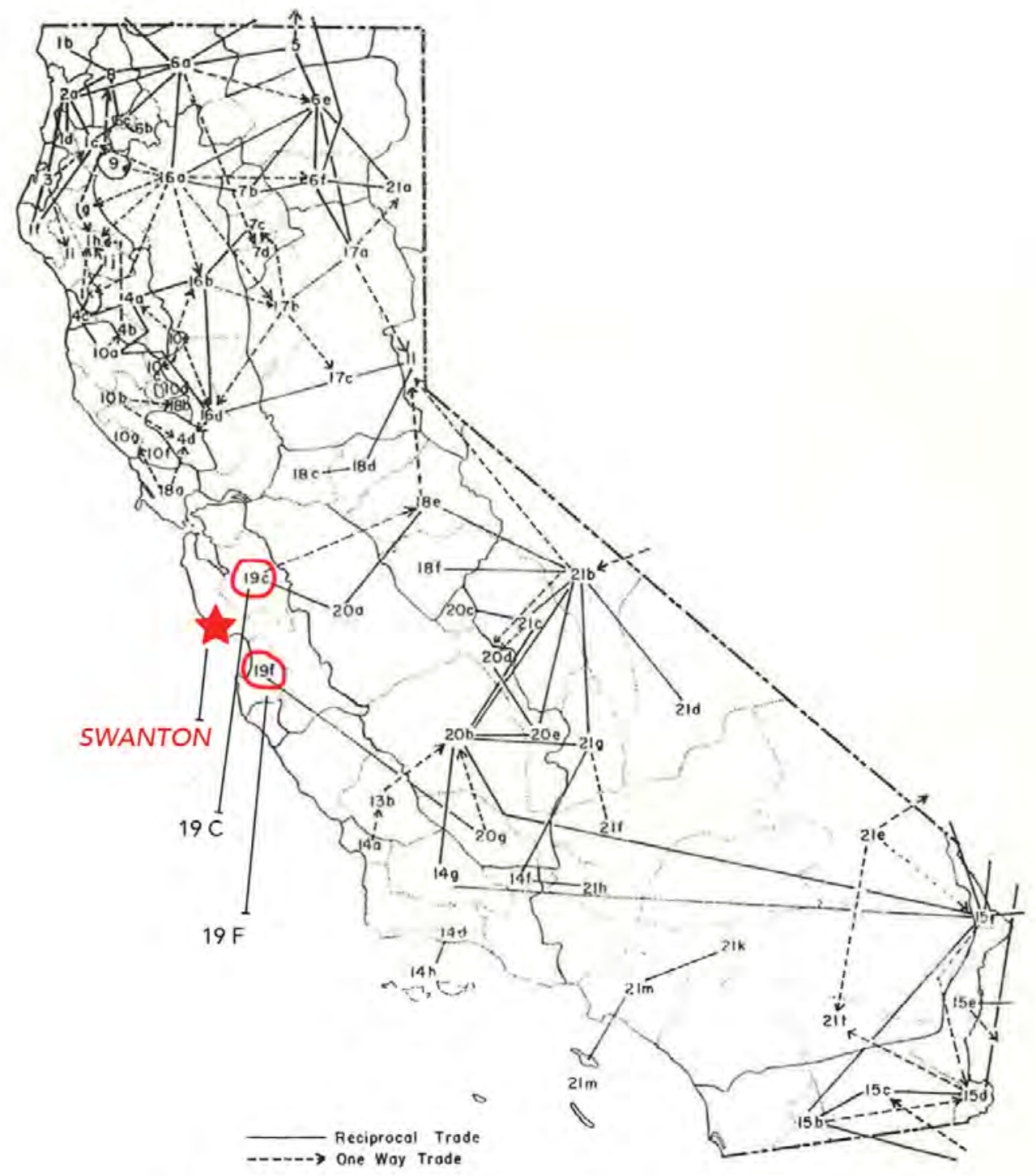

MAP 2. Trade Relations in Aboriginal California DAVIS, 1961

Figure 4: Trade Relations in Aboriginal California. Trading relationships near the Santa Cruz hills and the Monterey Bay area correlate with populations of Indigenous Peoples living in the areas labeled 19c (i.e. Santa Clara) and 19f (i.e. Monterey) (Davis, 1961, 71). Modified from the original. 


\section{Land Management}

Many Native American groups engaged in large-scale environmental manipulation mainly through anthropogenic burning. ${ }^{50}$ Fire was a pre-Columbian land management tool. ${ }^{51}$ Friar Juan Crespí of the 1769 Portolà expedition observed burned meadowlands as the group traveled along the coast from Santa Cruz to San Francisco and specifically noted that the Indigenous Peoples burned the meadows "for a better yield of the grass seeds that they eat. ${ }^{\prime 52}$ Later, at the newly established Royal Presidio of Monterey, Governor Fages prohibited landscape burning, writing that Indigenous Peoples "are wont to cause these fires because they have the bad habit, once harvesting their seeds, and not having any other animal to look after except their stomachs, set fire to the brush so that new weeds may grow to produce more seeds, also to catch rabbits that get overcome and confused by the smoke."53

The Indigenous Peoples of the Santa Cruz Mountain range had adventitious subsistence strategies that allowed for co-harvesting, long-term storage, and food exchange systems based on their access to the region's ecological diversity: "marine, sandy beach, rocky shore, tidal and freshwater marsh, grassland prairie, oak grassland

\footnotetext{
${ }^{50}$ McNeill, 2003, 16.

${ }^{51}$ Jon E. Keeley, "Native American Impacts on Fire Regimes of the California Coastal Ranges," Journal of Biogeography 29, no. 3 (2002): 303-320.

52 Juan Crespl, A Description of Distant Roads Original Journals of the First Expedition into California, 1769-1770, trans. Alan K. Brown (San Diego, CA: San Diego State University, 2001), 565-97, quoted in Cuthrell, et al., 2012, 151. The author obtained a copy of the original translation and cannot locate the quote.

${ }^{53}$ Pedro Fages, A Historical, Political, and Natural Description of California by Pedro Fages, Soldier of Spain, Dutifully Made for the Viceroy in the Year 1775, trans. Herbert Ingram Priestley (Berkley, CA: University of California Press, 1937), quoted in Cuthrell, et al., 2012, 151. The author obtained a copy of the original translation and cannot locate the quote.
} 
savanna, riparian, chaparral, mixed hardwood, and evergreen forest habitats. ${ }^{.54}$ Forests provided resources seasonally and coastal areas provided reliable resources year round allowing for long-term habitation..$^{55}$ Grasslands provided a reliable source of storable plants and the animals attracted to them from mid-summer to early fall, reducing the need for summer residential mobility, even in times of lean resources. ${ }^{56}$

A multitude of niche vegetative environments, each with distinct responses to fire, comprise Central California. ${ }^{57}$ California's fire-adapted vegetative communities are high in biodiversity and have distinct adaptations to local microclimates. They are situated in a Mediterranean climate that enhances vegetation quantity during wet, mild winters and dry summers, and that transforms the lush growth into potential fuel sources. ${ }^{58}$

Native grassland and chaparral burning practices mimicked natural fires in a controlled manner in late summer and early fall. ${ }^{59}$

The Indigenous Peoples chose the Swanton/Scott Creek Watershed area for specific and abundant flora and fauna resources on land and fresh and salt water to eat, trade, and use for medicine. It is interesting to note that the Swanton/Scott Creek Watershed has at least $10-12 \%$ of California's flora within its geomorphological boundaries. $^{60}$

\footnotetext{
${ }^{54}$ Cuthrell, et al., 2012, 154; The most comprehensive bibliography regarding California and anthropogenic burning is by Cuthrell, et al., 2012, 170-172.

${ }^{55}$ Ibid., 164.

${ }^{56}$ Ibid.

${ }^{57}$ Ibid., 158.

58 Ibid., 155; Ann Lucy Wiener Stodder, Mechanisms and Trends in the Decline of the Ohlone Indian Population of Central California: Nutrition and Health in Pre-contact California and Mission Period Environments (Salinas, CA: Coyote Press, 1986), 11.

${ }^{59}$ Stodder, 1986, 11.

60 James A. West, "Traversing Swanton Road," University of California Santa Cruz Arboretum, 2015, 1, http://arboretum.ucsc.edu/pdfs/TraversingSwanton.pdf.
} 
Inhabitants who burned shrublands did so to increase easily harvestable plant and animal resources: burning in autumn resulted in grasses followed by legumes and other forbs through winter, spring, and early summer. ${ }^{61}$ The Native Americans' burning reduced the number of sprouting trees and shrubs; stimulated increased growth and abundance of annual seed-bearing plants, forbs, and bulbs; limited the amount of dead plants, brush, and growth of large trees; and created grassy meadows for grazing of deer, elk, and antelope, which were all important food items for the Ohlone. ${ }^{62}$

Researchers have used optimality models to outline potential economic consequences of different fire regimes. ${ }^{63}$ Specifically, researchers have studied changes in geological dynamics with fire management implementation, fire management, and resource control interactions, and also have studied how fire-managed resources affected the culture (e.g. food processing, gender labor divisions) ${ }^{64}$ The Ohlones' complex controlled burning and management of grasslands and chaparral evolved into a sophisticated and successful cultural and biological adaptation. ${ }^{65}$

\footnotetext{
${ }^{61}$ John Bean and Harry W. Lawton, "Some Explanations for the Rise of Cultural Complexity in Native California with Comments on Proto-Agricultural and Agriculture," in Patterns of Indian Burning in California: Ecology and Ethnohistory, eds. Henry T. Lewis and Lowell Hohn Bean (Ramona, CA: Ballena Press, 1973), $\mathrm{xxx}$.

${ }^{62}$ Stodder, 1986, 11; Boulé, 1992, 38.

63 Joel Orth, email message to author, June 5, 2015. Orth comments that though much is written about "fire ecology" it is important to remember "forest ecology." Nancy Langston, Forest Dreams, Forest Nightmares: The Paradox of Old Growth in the Inland West (Seattle, WA: University of Washington Press, 1995) provides a case study in Oregon's blue mountains that explains how most Western forests were the product of Native American burning; forests were harvested by Europeans and the second growth grew back without frequent burning, which resulted in the risk of "megafires."

${ }^{64}$ Cuthrell, et al., 2012, 159-160.

${ }^{65}$ Stodder, 1986, 7.
} 
Coastal Ohlone Dietary Resources and Missionization

The archaeological record provides information concerning both the dietary habits of the Ohlone and the demographic orientation to the distribution of economic resources as well as how these sources combined to present subsistence and economy. In addition, the record offers details about crucial physiological and ecological elements that intruded upon and irreversibly altered the process of missionization. ${ }^{66}$ Before Europeans came to the California Central coast, the Coastal Ohlone had rich dietary resources.

These resources provided the group a year round and balanced diet of aquatic and terrestrial foods. Please refer to Table 1: Coastal Ohlone Dietary Resources for information on the name, genus, preparation, and collection of foods.

Table 1: Coastal Ohlone Dietary Resources. Coastal/Aquatic Resources, terrestrial flora, and terrestrial faunal food resources included but are not limited to those in the table. ${ }^{67}$

\begin{tabular}{|l|l|l|l|}
\hline Coastal Ohlone Dietary Resources \\
\hline Coastal/Aquatic Resources & Preparation/Use/Notes & Time of Year \\
\hline Common Name & Genus species & Dried primarily for salt & Mar to mid-Apr \\
\hline Seaweed/Kelp & Porphyra spp. & $\begin{array}{l}\text { Traded (dried shellfish, } \\
\text { smoked and dried fish) }\end{array}$ & Mar to mid-Apr \\
\hline Salmon & & & Jul to mid-Apr \\
\hline Shellfish & & & Jul to mid-Sep \\
\hline Smelt & & Clubbed on the beach & Jul to mid-Sep \\
pups & & & Jul to Nov \\
\hline Surf fish & & & Dec to Feb \\
\hline Waterfowl & & & \\
\hline
\end{tabular}

\footnotetext{
${ }^{66}$ Ibid., 7.

${ }^{67}$ The following documents were used to create Table 1: Stodder, 1986; Lightfoot and Parish, 2009; West, 2015; and United States Department of Agriculture (USDA) Plants Database - Plant Fact Sheets: Pacific Madrone, California Laurel, and California Hazelnut.
} 


\begin{tabular}{|c|c|c|c|}
\hline \multicolumn{4}{|c|}{ Terrestrial Floral Resources } \\
\hline Common Name & Genus species & Preparation/Use/Notes & Time of Year \\
\hline Miner's Lettuce & $\begin{array}{l}\text { Claytonia perfoliata } \\
\text { subsp. perfoliata }\end{array}$ & & Mar to Jun \\
\hline Bracken Fern & $\begin{array}{l}\text { Pteridium aquilinum } \\
\text { var. pubescens }\end{array}$ & & Mar to Jun \\
\hline Pinole clover & $\begin{array}{l}\text { Trifolium bifidum var. } \\
\text { decipiens }\end{array}$ & $\begin{array}{l}\text { Pinole seed boiled with } \\
\text { water to make mush }\end{array}$ & $\begin{array}{l}\text { Mar to Jun; Mid- } \\
\text { Sep to Nov }\end{array}$ \\
\hline Wild onion bulbs & Allium spp. & & N/A \\
\hline $\begin{array}{l}\text { Corms and bulb } \\
\text { tuber }\end{array}$ & $\begin{array}{l}\text { Brodiaea spp., } \\
\text { Dichelostemma spp., } \\
\text { and Triteleia spp. }\end{array}$ & & mid-Apr to Jun \\
\hline $\begin{array}{l}\text { Tule roots } \\
\text { and pollen }\end{array}$ & $\begin{array}{l}\text { Schoenoplectus } \\
\text { californicus }\end{array}$ & Made into balls and baked & mid-Apr to Jun \\
\hline Peppergrasses & Lepidium spp. & $\begin{array}{l}\text { Pinole seed boiled with } \\
\text { water to make mush }\end{array}$ & mid-Apr to Nov \\
\hline Legumes & $\mathrm{N} / \mathrm{A}$ & $\begin{array}{l}\text { Possibly Lupinus } \\
\text { succulentus (arroyo lupine) } \\
\text { observed circa two decades } \\
\text { ago on Swanton land }\end{array}$ & Jul to mid-Sep \\
\hline $\begin{array}{l}\text { Elderberries and } \\
\text { Huckleberries }\end{array}$ & $\begin{array}{l}\text { Sambucus spp. and } \\
\text { Vaccinium spp. }\end{array}$ & $\begin{array}{l}\text { Berries eaten fresh, } \\
\text { cooked, dried, and made } \\
\text { into cider }\end{array}$ & Jul to Feb \\
\hline $\begin{array}{l}\text { California } \\
\text { Buckeye }\end{array}$ & Aesculus californica & $\begin{array}{l}\text { Nuts were stored and eaten } \\
\text { year round }\end{array}$ & mid-Sep to Nov \\
\hline $\begin{array}{l}\text { California Bay } \\
\text { Laurel }\end{array}$ & $\begin{array}{l}\text { Umbellularia } \\
\text { californica }\end{array}$ & $\begin{array}{l}\text { Kernel of fruit eaten raw, } \\
\text { roasted, and ground into a } \\
\text { powder to made cakes }\end{array}$ & mid-Sep to Nov \\
\hline $\begin{array}{l}\text { California } \\
\text { Hazelnut }\end{array}$ & $\begin{array}{l}\text { Corylus cornuta } \\
\text { subsp. californica }\end{array}$ & $\begin{array}{l}\text { Nuts eaten raw, roasted, } \\
\text { pounded into cakes, and } \\
\text { boiled to extract the oil } \\
\text { (used as flavoring) }\end{array}$ & mid-Sep to Nov \\
\hline Madrone & Arbutus menziesii & $\begin{array}{l}\text { Berries eaten fresh, } \\
\text { cooked, and dried }\end{array}$ & Dec to Feb \\
\hline $\begin{array}{l}\text { Black Oak, Tan } \\
\text { Oak and Coast } \\
\text { Live Oak }\end{array}$ & $\begin{array}{l}\text { Quercus kelloggii, } \\
\text { Nothoithocarpus } \\
\text { densiflorus } \\
\text { (previously known as } \\
\text { Lithocarpus } \\
\text { densiflorus) and } \\
\text { Quercus agrifolia }\end{array}$ & Acorns & Dec to Feb \\
\hline Mushrooms & & & Dec to Feb \\
\hline \multicolumn{4}{|c|}{ Terrestrial Faunal Resources } \\
\hline Common Name & Genus species & Preparation/Use/Notes & Time of Year \\
\hline $\begin{array}{l}\text { Large and small } \\
\text { game animals }\end{array}$ & & $\begin{array}{l}\text { Availability of species } \\
\text { differed by season }\end{array}$ & Year round \\
\hline Fowl and eggs & & $\begin{array}{l}\text { Availability of species } \\
\text { differed by season }\end{array}$ & Year round \\
\hline
\end{tabular}

${ }^{68}$ Russ White, verbal communication with author, 2014(?), stated that he remembered hearing something about using seeds to stun fish in fresh water. This information needs to be verified for accuracy. 


\begin{tabular}{|l|l|l|l|}
\hline & & & \\
\hline Grasshoppers & & $\begin{array}{l}\text { Gathered en masse by the } \\
\text { use of small brush fires }\end{array}$ & mid-Apr to Jun \\
\hline Cormorant chicks & & & Jul to mid-Sep \\
\hline
\end{tabular}

Between 1770 and 1835, missionization gradually depleted the Ohlone population as well as the hunting and gathering on the landscape that would become Swanton Valley ${ }^{69}$ The disruption of their culture's stable and successful ecological adaptions significantly contributed to its devastation. The collapse of the population was also attributed to the introduction of disease, baptism and forced conversion, and declining birth rates. ${ }^{70}$ The quality and content of the Ohlones' diet, health, longevity, and productivity of men, women, and children decreased because the mission economy changed their daily routines, labor distribution, planting of crops, etc. ${ }^{71}$ The market based mission economy also destroyed the Ohlones' relatively efficient subsistence system based on seasonal gathering and fire management, making the population barely able to maintain viability. By 1770 , there were only about 600 Ohlone from Davenport to Aptos. ${ }^{72}$

Missionization also undermined the Ohlone by replacing their hunting-gatheringfire regime with Spanish style agriculture. The colonizing authorities in the late eighteenth century curtailed burning practices among California Indians, and instead the Spanish grazed animals on the land around the missions. ${ }^{73}$ Before the Spanish forcibly introduced

\footnotetext{
${ }^{69}$ Levy, 1978, 486.

70 lbid.

${ }^{71}$ Stodder, 1986, 23.

${ }^{72}$ Robert Cartier, "An Overview of Ohlone Culture," Santa Cruz County History -- Spanish Period and Earlier, 1991, http://www.santacruzpl.org/history/articles/248/. Though nothing can undo the harm that came to the Indigenous Peoples of the Central Coast, recent conversations with the church resulted in a homily, Mass of Healing and Reconciliation, December 22, 2012, by the Most Reverend Richard J. Garcia, Bishop of the Diocese of Monterey, at Old Mission San Juan Bautista.

${ }^{73}$ S.L. Stephens and N.G. Sugihara, "Fire Management and Policy Since European Settlement," in Fire in
} 
farming to Indigenous Peoples, there was no reason for the Ohlone to farm, as they already had access to abundant local resources and those resulting from controlled burning.$^{74}$ The Ohlone had an efficient system in place that balanced human needs and ecological sustainability. Their system weathered California's climatic variations and sustained substantial population levels over the long term.

Imperial Spain's colonization of California began in 1697. Mexico gained independence from Imperial Spain on September 27, 1821. Mexico officially assumed control of the area at that time. The last governor sent to California from Mexico City was Manuel Micheltorena, who came in 1842 and served until 1845. In 1848, California was acquired by the United States under the terms of the Treaty of Guadalupe Hidalgo.

The Santa Cruz Mission began on September 25, 1792 with donations from local missions during Spanish rule. ${ }^{75}$ The first stone was laid on February 23, 1793 and dedicated in March 1794. Subsequently, the Mexican government secularized the Mission in 1834. In 1857, the Mission was completely destroyed by an earthquake. During the period of the Mission's decline, the Indigenous Peoples dispersed. The secularization of the Mission resulted in Mexican settlers, colonization, and attempts to acquire Mission lands. ${ }^{76}$

California's Ecosystems, eds. N.G. Sugihara, J.W. van Wagtendonk, K.E. Shaffer, J.A. Fites-Kaufmann and A.E. Thode A.E. (Berkeley, CA: University of California Press, 2006), 432; Lightfoot and Parrish, 2009, 94-96; Cuthrell, et al., 2012, 155.

${ }^{74}$ Lewis, 1973, 3.

${ }^{75}$ Harrison, 1892, 20-21: The Santa Cruz Mission was given the following resources by local missions, "Santa Clara Mission thirty cows, five yoke oxen, fourteen bulls, twenty steers and nine horses; Carmel Mission seven mules; San Francisco Mission five yoke oxen; sixty sheep, ten rams, and two bushels of barley."

${ }^{76}$ Ibid., 26. 
The locations of missions were determined by their proximity to presidios or Native American villages, with no thought to the quality of the farmland..$^{77}$ The mission economy and related European agricultural production, often in poor soil, required tremendous amounts of Native American labor, though the variety of widely available wild foods was spurned by the Europeans even during times of famine ${ }^{78}$ The Spanish distained the Native American subsistence mode of hunting and gathering, even though in reality that mode was highly efficient and successful. ${ }^{79}$ The ranchero dons of Santa Cruz County used the mountains and plains to graze cattle by the thousands. ${ }^{80}$ The mission agriculture and pasture lands swiftly and irreversibly altered the ecological patterns of the land, with native grasses disappearing along with a large number of game. $^{81}$

The significant ecological changes in Santa Cruz due to farming and grazing reduced the native plants. Nevertheless, Swanton's more than 150 years of agriculture and industrial activities had not resulted in a significant invasion of European non-native taxa. ${ }^{82}$ A 30-year study of the ecology of the Scott Creek Watershed and environs has documented more than 200 native species and approximately $10-12 \%$ of all California's flora both native and introduced. ${ }^{83}$

\footnotetext{
77 Stodder, 1986, 29.

${ }^{78}$ Harrison, 1892, 20-21; Stodder, 1986, 28.

${ }^{79}$ Stodder, 1986, 25.

${ }^{80}$ Harrison, 1892, 60.

${ }^{81}$ Stodder, 1986, 33.

${ }^{82}$ West, 2015, 108.

${ }^{83}$ Ibid., 1.
} 
Mexican Land Grants

The recorded history of the Swanton Pacific Ranch as a place begins with Spanish occupancy in 1839 and reflects Spanish Imperial measures and nomenclature. In 1839, Hilario Buelna received the property rights to Agua Puerca y las Trancas, translated as hog water and the bars, originally known as Rancho el Jarro (see Figure 5: Hand Drawn

\section{Map of Diseño del Rancho Agua Puerca y las Trancas: Santa Cruz County,}

California). The Rancho, located along the coast in present day Santa Cruz County, California, is named after the two creeks that are its boundaries, Agua Puerca Creek (a.k.a Arroyo Agua Puerca) and Las Trancas Creek (a.k.a Arroyo las Trancas) ${ }^{84}$ Hilario Buelna's claim and subsequent claims by Thomas W. Russell and José de la Cruz Rodriguez were not recognized by the United States Government. ${ }^{85}$

On November 2, 1843, the Rancho Agua Puerca y las Trancas land grant was made to brothers-in-law Ramón Rodríguez and Francisco Alviso by Mexican Governor Manuel Micheltorena. After both the Mexican-American War of 1846-48 and California's establishment as a state in 1850 , land grant ownership required validation. ${ }^{86}$

\footnotetext{
${ }^{84}$ Donald Thomas Clark, Santa Cruz County Place Names: A Geographical Dictionary (Scott Valley, CA: Kestrel Press, 2008), 257, discusses in significant detail the confusion that has surrounded the name of the rancho over the years, possible mistranslations, and historian's theories and documentation. In the section Mexican Land Grant, Smith (July 1990) himself even asked about the word choice: "The grant was named Rancho Agua Puerca y Las Trancas. With all the beautiful Spanish language to chose from, it literally means Hog Water and the Bars. Agua Puerca probably refers to the stagnant water in the stream which comes out at Davenport Landing, the original southerly boundary; and Las Trancas refers to placing poles for a gate or barrier in a narrow canyon just south of Waddell Creek."

${ }^{85}$ Clark, 2008, 261.

${ }^{86}$ Warrick, 1982, 11: "During the Spanish and Mexican periods...land titles had never been systematized as they [later would be by the United States]...descriptions of land and maps were sketchy, some resembling children's drawings....in the Mexican land title system, creek beds with varying boundaries, or tree stumps, marked the end of one property and the beginning of another. Consequently the 500 ranchos that existed in California... over 800 claims were filed covering overlapping portions of the ranchos. An act of Congress in 1851 established a commission to assess the claims and reorganize the Mexican land title system. From January 1852 until 1856 the commission held hearings in San Francisco."
} 


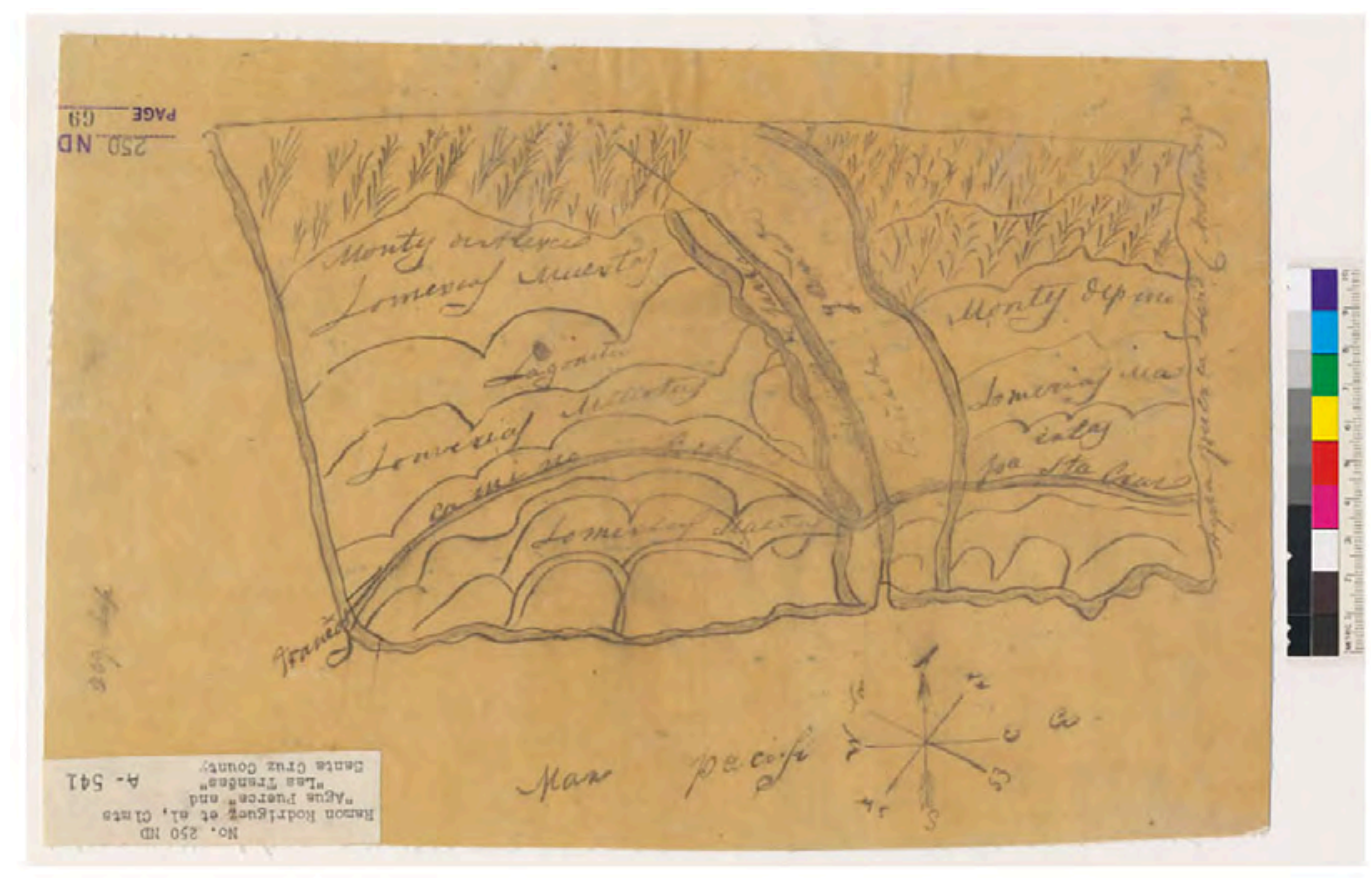

Figure 5: Hand Drawn Map of Diseño del Rancho Agua Puerca y las Trancas: Santa Cruz County, California. Agua Puerca y las Trancas is 4421.52 acres and grant number 206. Courtesy of UC Berkeley, Bancroft Library. http://content.cdlib.org/ark:/13030/hb1z09n6kx/?layout=metadata

In 1856, Ramón Rodríguez and Francisco Alviso had to prove their claim, which was ultimately successful, as evident in Claiming the Rancho Aqua Puerca y Las

Trancas, Appellants, vs. The United States:

Claiming the Rancho Aqua Puerca y Las Trancas, Appellants, vs. The United States. Objections by the Board met by the additional testimony taken in this Court. Claim for one league of land in Santa Cruz County, rejected by the Board, and appealed by the claimants. D. S. Gregory, for Appellants. William Blanding, United States Attorney, for Appellees.

The claim in this case was rejected by the Board on the grounds: 1st. That there was no proof of occupation and cultivation. 2d. No juridical measurement or possession. 3d. No proof of the bound areas or of the quantity of land included in the claim. These objections have been met by additional testimony taken in this Court. José de la Cruz Rodríguez deposes that he was born within a few miles of the Rancho; that its boundaries are well known; that they are, on the north the Sierra, ${ }^{87}$ on the east the Cañada of Agua Puerco, on the south the ocean, and on the west the Cañada de las Trancas. He also swears that in March, 1844, which was about five months after the grant, it was occupied by Rodríguez

\footnotetext{
${ }^{87}$ Smith, 1990, "An interesting sideline is that in the translation of the description to English, the transcriber recognized the word Sierra and left that as the northeasterly boundary instead of using 'mountain ridge.' Some smart lawyer could have laid claim to a strip through Modesto."
} 
and Alviso, the grantees; that they built houses and corrals, and lived upon it for two years after that time, and that it has remained in their possession ever since. Cornelio Perez testifies to the same effect. And Hiram L. Scott not only testifies to the general recognized boundaries of the tract called "Agua Puerca y las Trancas," but states that the land contained within them is about a league.

No question appears to have been made before the Board as to the authenticity of the grant, and the case has been submitted to this Court without argument on the part of the United States. The boundaries of the tract as sworn to by the witnesses are the same as those mentioned in the grant; and the quantity of land contained within appears to correspond with sufficient exactness to that mentioned in the condition, viz: "one league, a little more or less, as explained by the sketch." I think, therefore, that the claim should be confirmed according to the boundaries mentioned in the grant and as shown on the map. ${ }^{88}$

Rodríguez and Alviso's private land claim is listed in the Sacramento Daily Union as September $28,1866 .^{89}$ Rodríguez and Alviso's land patent, grant number 206, from the United States Government, confirmed under President Andrew Johnson, was issued on March $1,1867 .{ }^{90}$ The formalization of ownership and land boundaries established in this court document provided the basis for the division and sale of the property going forward. The same year their patent was confirmed, Rodríguez and Alviso, after going through the process of proving their claim, including testimony that their homes were located on the rancho, sold the property to James Archibald. See Figure 6: Traverse Line Run from Redmond Post A.P.5 to Large White Post A.P.6. U.S. Coast Survey (top image) for an 1868 map of the rancho, a snapshot of what Archibald purchased. Many a current Cal Poly student would agree with the description of the area noted as

\footnotetext{
${ }^{88}$ Ogden Hoffman, Reports of Land Cases Determined in the United States District Court for the Northern District of California: June Term, 1853 to June Term, 1858, Inclusive (San Francisco, CA: N. Hubert, 1862) 175-176.

${ }^{89}$ Staff Writer, "United States Surveyor General's Office San Francisco," Sacramento Daily Union (Sacramento, CA), Jan. 1, 1868.

${ }_{90}$ The patent date and grant number are usually given without citation. The patent date and grant number has been confirmed in three primary sources: Staff Writer, 1868, 6; Hoffman, 1862, 175-176; and H.I. Willey, "Report of the Surveyor-General of the State of California, from August 1, 1884, to August 1, 1886," ed. Office of Surveyor-General State of California (Sacramento, CA: State Office, 1886), 11.
} 
"numerous deep and impassable canons [canyons]." ${ }^{\text {"1 }}$ Figure 6: Traverse Line Run from Redmond Post A.P.5 to Large White Post A.P.6. U.S. Coast Survey (bottom image), a close up of an 1868 map, provides a close up of features on the rancho identifying different land types, building structures, and waterways.

${ }^{91}$ Russ White, verbal communication with author, August 10, 2015. 


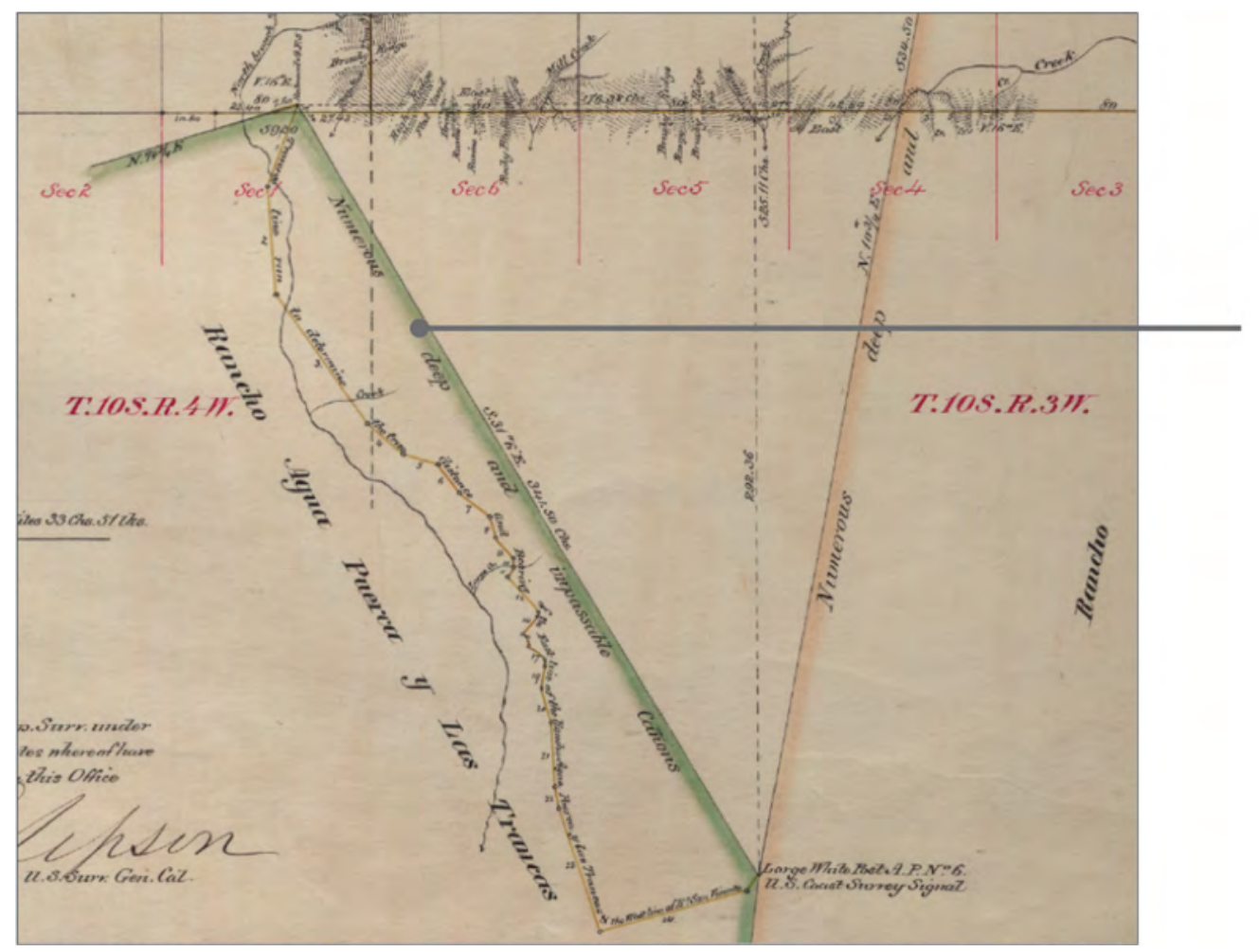

Numerous deep and impassable Canons

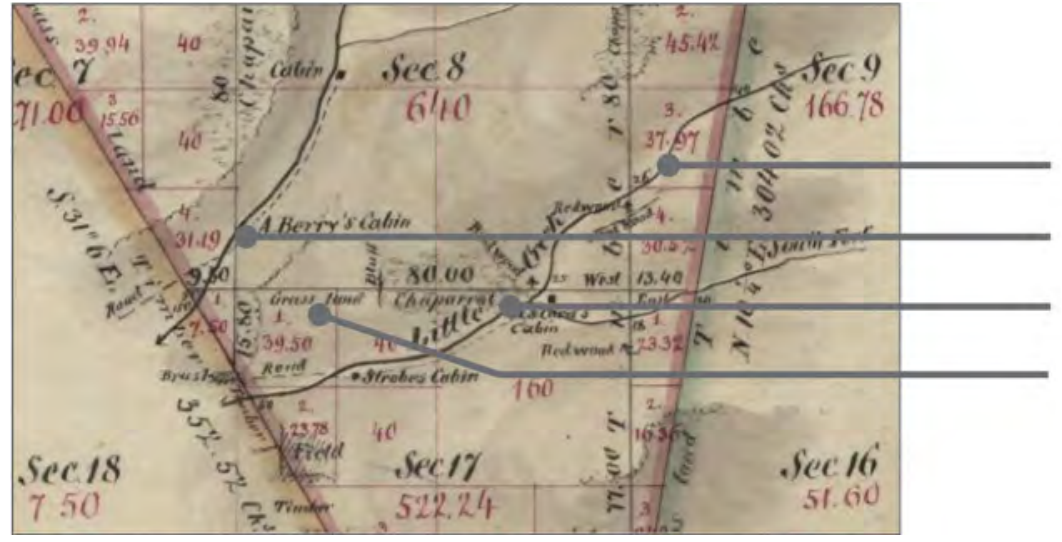

Little Creek

Berry's Cabin

Chaparral

Grassland

Figure 6: Traverse Line Run from Redmond Post A.P.5 to Large White Post A.P.6. U.S. Coast

Survey. 1868 General Land Office Records (GLO) Rancho Agua Puerca y Las Trancas Plat Map. The top image provides a basic survey of the land grant boundaries. While this map is sparse in features, it conveys surveyor notations of what line was used to determine the distance of the Rancho and the boundary of its neighbor Rancho San Vicente. The bottom image provides a more detailed version of the area. United States Department of Interior, Bureau of Land Management, General Land Office Records, DM ID 380771, Lauren Upson (Surveyor General), 1868,

http://www.glorecords.blm.gov/details/survey/default.aspx?dm_id=380772\&sid=h3jklvyg.mci\&surveyDetails Tablndex=1\#surveyDetails TabIndex=1. 
CHAPTER 2: SWANTON (1800-1950)

Introduction

This thesis is focused on Swanton Pacific Ranch and adjacent areas; the original boundaries of the Rancho are not identical to those of modern Swanton Pacific (see Figure 10: Map Santa Cruz County, 1880-81).$^{92}$ The historical documentation of Swanton covering 1800-1950 varies in specificity and accessibility (many documents are held in personal and family archives). Santa Cruz has a tradition of local histories which have covered aspects of the Swanton Valley, Davenport, and adjacent areas. ${ }^{93}$ Swanton is usually referenced as a footnote in a larger historical discussion, the backdrop for a short newspaper article, or part of a biographical sketch. There is a generally agreedupon historical timeline within the current literature, but there is a focus on large landowners (settlers and industry). ${ }^{94}$

Swanton Pacific Ranch does not exist in a vacuum and many industries and land uses overlap with the greater Swanton area: the boundaries that encompass the now

\footnotetext{
${ }^{92}$ Ownership of the Rancho and the surrounding ranchos changed boundaries significantly over time, creating a complicated land use/owner history. It takes the collection of the information and then the ability to parse it out to be used effectively. This should be addressed in the future. The following deed, easement, and lease information, as collected by Kim Stoner, documentation shared with the author, August 2014, provides a glimpse of the intricacies: (1) June 26, 1905, Joseph Bloom to Shore Line Investment Company the water rights to Little Creek and Scott Creek for \$10; (2) June 27, 1905, Shore Line Investment Company a strip of land 60 feet wide through the property formerly of Joseph Bloom to Ocean Shore Railway Company \$5; (3) August 7, 1907, Shore Line Investment Company indenture to Ocean Shore Railway Company [unclear number of] acres and railroad use only bounded by A. Gianone and Coast Land and Dairy Company $\$ 20$.

${ }^{93}$ An example is that of Alverda Orlando, local historian, who has an in-depth knowledge of Santa Cruz, specifically the Davenport area, and is a prolific author.

${ }_{94}$ The following text is an amalgamation of numerous sources, the majority of sentences of which are paraphrased. All effort was made to identify the source and indicate exact quotations. Unfortunately, the wording is often identical or extremely similar in sources, usually without any attribution, so that it is unclear where information was collected, whose words were written first, who reiterated them, and what is considered "common knowledge." These sources include but are not limited to: Smith, 1990; Koch, 1991; Old Cal Poly Agriculture Website, September 1997, found in the Swanton Pacific Railroad Society Librarian's, Lou Haughney, papers, Box 2. Clark, 2008; Cal Poly, 2011, 19-24.
} 
Swanton Pacific Ranch. Significant papers and books have been written on industries, as well as on famous residents. These histories include those about Davenport, the Ocean Shore Railroad, the lime industry, the lumber industry (San Vicente Lumber and Big Creek Lumber), dairies (Coast Dairies), the Seaside School District (see Appendix A), and Big Creek Electric Power and Light Company. There are newspaper articles and short articles and sections of books providing the historical context of Swanton. The Santa Cruz Public Library and the Santa Cruz Museum of Art and History have rich historical collections including clipping files, short topical essays, and large photographic collections from local families. ${ }^{95}$ Current and former residents have been interviewed by numerous historians and are often cited as the source of historical information not otherwise recorded. They also provide verification of historical facts. ${ }^{96}$ Immense unexplored scholarship lies within this time period because of the various sources of information that exist that have not been explored or analyzed as well as the variety of accounts of places and people.

Covering this time period is a book unto itself and this thesis provides resources that could support such an endeavor. This time period is difficult to distill into a few pages. This chapter will not endeavor to try. Instead, it will focus on examples of historical narratives during this time period, how they can be deconstructed and studied using alternative narratives, and tools to provide additional context. Three examples will be reviewed: first, Al Smith's 1990 interview providing a historical narrative of the area

\footnotetext{
${ }^{95}$ The California Digital Newspaper Collection, available online http://cdnc.ucr.edu/cgi-bin/cdnc, can provide further descriptions and information on events and the general atmosphere of the Swanton Valley; the Santa Cruz Museum of Art and History Archives Collection Guides provide information on for photographs, newspaper clippings, and more http://www.santacruzmah.org/learn/collection-guides/.

${ }^{96}$ See Koch 1973, 1991 and Clark 1986, 2008.
} 
discussing the transition from the Rancho era to the Swanton era, which has dominated much of the recorded historical discussion of the area; second, the historical maps that refer to Scott Creek and the different variants providing an example of how maps can act as another tool in tracking history; third, aerial imagery that offers an example for studying history using the example of land use.

Deconstructing Al Smith's 1990 Interview - Rancho Era to Swanton Era (1800-1940s)

It is unclear the purpose of Smith's interview and who conducted the interview. There are no citations given to support this account of Swanton history. How Smith came to learn of these events/people and why he (or the interviewer) chose to focus on them is unclear. The interview does provide a short, comprehensive narrative specific to Swanton Pacific Ranch on which to fuel a larger discussion. There is no implication that any of the narrative is incorrect. However, there are many sources of information from this era and it is not yet clear how they fit together.

Quotes from Smith's (1990) interview are presented as well as additional historical narratives and tools that may include factual disagreements and interpretive differences. The one component of Smith's narrative that is problematic is that his conception of history and how things happen is a sort of "great man theory" where the focus is on one important shaper, in this case Fred Swanton. ${ }^{97}$ It is possible that someone like Smith who was also a "great man" and shaper of events might create a history that was blind to the many other people and forces transforming the land.

\footnotetext{
${ }^{97}$ Great man theory as described by Dictionary.com is "an approach to history associated with the nineteenth-century Scottish historian Thomas Carlyle, who declared, 'The history of the world is but the biography of great men.' Carlyle argued that heroes shape history through the vision of their intellect, the beauty of their art, the prowess of their leadership, and, most important, their divine inspiration."
} 
The "big man" version of Swanton history starts with Santa Cruz and San Francisco. Santa Cruz had a strong market economy supported by logging, lime processing, dairy production, agriculture, commercial fishing and whaling, and tourism (due to Santa Cruz's mild climate and beautiful scenery). This market supported Santa Cruz, its surrounding areas, and nearby San Francisco. In 1866 the town of Santa Cruz was incorporated and subsequently in 1876 it was incorporated as a city. ${ }^{98}$

The increasing market integration of the landscape more clearly defined Swanton as a physical place but also as a legal, albeit an abstract one. That is, Swanton's natural resources began to be turned into a wider variety of goods for the city. New market connections (local markets in Santa Cruz and the City, plus connections to global markets) allowed an ever-increasing number of Swanton's natural resources to be profitably exploited. The square league Rancho extended down the coast in the east from Arroyo Agua Puerca (old Davenport Landing) to the western Cañada de las Trancas; Scott Creek flowed through most of the Rancho from the northeast corner to the southwest corner into the Monterey Bay. ${ }^{99}$ In 1867 , the land patent was sold to a farmer, Scottish-born James Archibald.

Smith's (1990) History of Swanton - Mexican Land Grant, a description of that time period, is as follows:

...The land passed through several ownerships and ended up in the hands of James Archibald, who farmed it. He arranged for a Swiss dairyman, Ambrogio Gianone, to run the dairy. ${ }^{100}$ Mr. Gianone built the cheese house [i.e. a rock house cheese factory] (in 1867)

\footnotetext{
${ }^{98}$ Harrison, 1892, 65.

${ }^{99}$ Mildred Brooke Hoover, Historic Spots in California (Stanford, CA: Stanford University Press, 1948), 355.

${ }^{100}$ The cheese that was produced initially by Gianone was called Santa Cruz Jack Cheese, the precursor of Monterey Jack Cheese. Monterey Jack is listed in the Cal Poly, 2011, 22, but Hoover, 1948, 355 and Koch, 1991, 68, state that it was actually Swiss Cheese. Hoover, 1948, 355: Archibald hired a dairyman from Switzerland via Marin County, Ambrogio Gianone, to run the dairy in 1869.
} 
and had some shipwrecked ship's carpenters build the barn (in the late 1880's) at the south end of the valley, which stands today. (Approximately one-third of the westerly end of the barn blew off in a severe storm.) Later Mr. Gianone bought the north third of the Rancho, where Swanton Road crosses back over the ridge. It is known locally as Gianone Hill, and there are two families with fourth generation children living there today.

Mr. Archibald complicated matters by dying in Scotland in 1875. By the time the dust settled from a two-year lawsuit, Mrs. Archibald sold out to Joseph Bloom, who lined up water rights and farmed the valley. ${ }^{101}$ Homestead land was also available and settlers moved right up to the Mexican Land Grant line, which replaced the Sierra designation...Many of these families are still here. One homesteader was the Staub Family, great grandparents of Bud and Lud McCrary of Big Creek Lumber.

The string of Swanton owners transformed the natural world around them into capital. Archibald and Gianone turned grass into milk and cheese, ${ }^{102}$ owners leased their land or water for money, Fred Swanton used water to create electricity, and the Railroad capitalized on logging companies' need to transport lumber out of the Valley.

Early homesteaders, ranchers, and agricultural producers included W.H. Purdy, Alfred and Lucy Miller, J. Shaw, Harold Gianone, A.T. Brownfield, H.H. and Charles West, and the Staub Family. ${ }^{103}$ At the same time, John D. Davenport settled at El Jarro Point, later known as Davenport Landing, at the mouth of the Arroyo del Agua Puerca, about half a mile from today's town, which was a center for whaling, lumber, and lime shipping. ${ }^{104}$

Smith's (1990), History of Swanton - Beginnings of Swanton description of that time period is as follows:

Fred Swanton, who built the Boardwalk and was an early mayor of Santa Cruz, was an early enthusiast of hydroelectric power. He built a powerhouse on Big Creek, dams on Mill Creek and Big Creek, and several miles of flume. The plant produced electricity from 1899 to 1948 . In that year a forest fire burned the flume, and it was abandoned. It was the first

\footnotetext{
${ }^{101}$ Kim Stoner, documentation to author, August 2014: November 26, 1904: Ambrogio Gianone deeded the water rights to "Little Creek" and "Scott Creek" to Joseph Bloom for \$155.

${ }_{102}$ Cal Poly, 2011, 22: Archibald had 120 cows in his dairy in 1878.

${ }^{103}$ Koch, 1991, 68.

104 Ibid., 61.
} 
plant of the Central Coast Counties Gas and Electric Company, which is now part of PG\&E. With all this activity plus the logging, the area needed a post office. The natives liked Laurel Grove, the name of the inn and the livery stable, and petitioned the Postal Service, but Fred Swanton knew the U.S. Senator. The Swanton Post Office was closed in the late '30's.

The history of Laurel Grove's (a.k.a. Swanton), Ingalls Station's (a.k.a. Swanton), and the local post office's focus and inception are explained in slightly different ways in three regularly-cited sources with little to no citation themselves. ${ }^{105}$ In Smith's description, he focuses on the prominent and influential person who brought hydroelectric power to Santa Cruz through the use of the Ranch's water resources. Fred Swanton is responsible for Laurel Grove becoming Swanton. In other sources Laurel Grove is the focus of detailed facts, its tourist economy, and its importance as a post office, with Fred Swanton ancillary or non-existent. It is unclear if Swanton is considered less critical but became important in the historical narrative over time because of his political and economic influence, so other interpretations of the area are not as dominant today.

Clark's (2008), Santa Cruz County Place Names, entries include the following:

Laurel Grove: The hamlet now known as Swanton was once known as Laurel Grove; here was located the Laurel Inn. ${ }^{106}$

Swanton Post Office: In April, 1897, Pasquale Sonognini, a driver of the Santa CruzPescadero stage, applied for a post office to be known as Trancas...near the junction of Scott and Big creeks and on the Santa Cruz and Pescadero Stage Road (now Swanton Road). When the Post Office Department approved the office for opening May 28, 1897, it bestowed upon it the name of Swanton. The post office was closed on December 31, $1930 .^{107}$

\footnotetext{
${ }^{105}$ Smith, 1990; Koch, 1991; and Clark, 2008.

${ }^{106}$ Clark, 2008, 172.

${ }^{107}$ Clark, 2008, 341. This source states that the post office was proposed to be named Trancas, not Laurel Grove. The author speculates that Smith's (1990) note that Swanton knew a senator and his wishes overruled an Italian immigrant's name application is not surprising, considering the time period and Swanton's place in society.
} 
Clark's (2008) entry regarding Swanton focuses on Fred Swanton: ${ }^{108}$

Swanton: ...formerly Laurel Grove...Swanton, in 1906 became the northern terminus of the southern section of the Ocean Shore Railroad. Named for Fred Willer Swanton who built a powerhouse on nearby Big Creek. Swanton was undoubtedly the most active entrepreneur, promoter, and civic leader in the city of Santa Cruz around the turn of the century. Among his many efforts [related to Swanton] he: organized Big Creek Power Company, 1896; attempted to develop Swanton Beach Park, 1908; failed and deeded the land to the State for a state park; helped organize the 1915 Panama-Pacific Exposition in San Francisco; ${ }^{109}$ and was mayor of Santa Cruz, $1927-1933 .{ }^{110}$

And Ingalls Station is just referred to as part of the local transportation route:

Ingalls Station: This stagecoach station was located on Scott Creek...later became known as Swanton... ${ }^{111}$

Koch (1991) takes a different approach. ${ }^{112}$ She addresses the larger

Rancho Agua Puerca y las Trancas, not just Swanton, in terms of its location just

north of Davenport. She provides a list of owners and settlers (Archibald, Gianone, and the homesteaders mentioned previously); goes into great detail about the

Seaside School's locations over time, its school mistresses and graduates, and the issues created by the animals surrounding the school and the trail leading to it (ex. mountain lions); and describes the boarding of Swanton (Seaside School District) teachers in Laurel Grove Inn and its owners (the Mattei family). Koch also provides information about Fred Swanton forming Big Creek Electric Light and Power Company in 1896 and Swanton as the location of San Vicente Lumber Company's employee camps. In addition, Koch focuses on the settlers who were

\footnotetext{
${ }^{108}$ Harrison, 1892, 318-319, provides extensive biographical information on both Fred W. Swanton and his father Albion Paris Swanton.

${ }^{109}$ Swanton's connection to the PPIE is discussed in Chapter 3 in relation to Swanton Pacific Railroad.

${ }^{110}$ Clark, 2008, 340.

${ }^{111}$ Clark, 2008, 155; An example of a station account: Staff Writer, "Attempted Murder of Stagecoach Driver," Daily Alta California (San Francisco, CA), Aug. 23, 1872.

${ }^{112}$ Might this be because of her family's history and her place in Santa Cruz society or how her gender might shape the narrative?
} 
involved in these endeavors and their descendants in deference, while referring to Swanton as a place in an offhanded manner. ${ }^{113}$

Harrison (1892), Smith (1990), and Koch (1991) cover relatively similar time periods but cover different components of Swanton. The examples offered in the three sources make evident the variations on what are the "facts" and clearly indicate how the history of this area needs to be investigated further by exploring additional sources like newspapers, diaries, and oral histories from the descendants of the areas' settlers. Other sources have been located and more can be investigated about Big Creek Electric Light and Power Company, ${ }^{114}$ Ingalls Station, ${ }^{115}$ Laurel Grove, the environment (ex. 1904 forest fire), and its residents (especially the Mattei family). ${ }^{116}$

Local historians disagree about the degree to which Swanton was the driving force in the region's development. This could be identified as the central issue of the historiography on the Rancho to Swanton Eras. Using these and similar sources, a more robust narrative can emerge. The actual significance of Swanton to the region's development and the role of other actors remains an area of disagreement in the region's historiography and offers potential for future study.

Smith's (1990), History of Swanton - Beginnings of Swanton, description of that time period continues, focusing on the Ocean Shore Railroad:

\footnotetext{
${ }^{113}$ Koch, 1991, 68-72.

${ }^{114}$ Staff Writer, "Big Creek Electric Power Plant and Dam Big Creek Company Negotiates to Supply Electric Power to San Jose," Sacramento Daily Union (Sacramento, CA), Aug. 24, 1896; Staff Writer, "Floods and Landslide at Big Creek Electric Light and Power Co.," San Francisco Call (San Francisco, CA), Feb. 25, 1902; Staff Writer, "1904 Fire Big Flume Burned and Several Dams Threatened by Flames," San Francisco Call (San Francisco, CA), Sep. 7, 1904.

${ }^{115}$ Staff Writer, "Attempted Murder of Stagecoach Driver," Daily Alta California (San Francisco, CA), Aug. 23, 1872.

${ }^{116}$ Lisa Robinson, "The Mattei Family Photograph Album Collection," A Split History: Redwood Logging and Conservation in the Santa Cruz Mountains 7, (2004): 161.
} 
The Ocean Shore Railroad was organized to run along the coast between San Francisco and Santa Cruz. ${ }^{117}$ Construction was started from both ends, with the north ending at Tunitas Creek, about halfway between Half Moon Bay and Pescadero. The south line was built as far as Swanton. ${ }^{118}$ When the S.P. (Southern Pacific) built a parallel line to Davenport, the cement plant business dried up...A daily passenger train ran between Santa Cruz and San Francisco... [though 127 miles of track were never laid connecting the two cities... as a result S.P. passengers were transported over the 127 miles] by a Stanley Steamer bus. ${ }^{119}$

The Ocean Shore was also into real estate development, and in 1907 a town called Folger was laid out and approved by the County in the area around the big barn. ${ }^{120}$ Apparently the coffee business was on hard times too, because none of the $32425 \times 100$ foot lots sold. So, we still grow Brussels sprouts on the corner of Railroad Avenue and Fir Street. In 1922 employees of the Ocean Shore Railroad struck for higher pay, and that was the end of the railroad. ${ }^{121}$ For several years the University of California (Berkeley), College of Engineering, ran summer school here. Students would come by train and lay out roads and survey land for a summer semester. There are many stories told about cold water, poison oak and snakes, although there are only a few graduates left. (The building by the Red House was built by the engineering students.) ${ }^{122}$

While other resources do not dispute this content per say, there are primary sources, specifically maps that do not correspond with what was actually on the ground. Figure 7: Ocean Shore Railroad, for example, shows a 1909 advertisement for the proposed railroad expansion while a privately contracted surveyor's 1906 Map of the County of Santa Cruz incorrectly shows the Ocean Shore Railroad already continuing up the coast past Swanton. Using maps to learn more about the Ocean Shore Railroad is an example of how cartographic materials can provide context to history and the discrepancies that happen over time.

\footnotetext{
${ }^{117}$ Allen Collins, "The Spreckels Era in Rio Del Mar, 1872-1922," Santa Cruz County History - Places, 1995, http://www.santacruzpl.org/history/articles/407/.

${ }^{118}$ Collins, 1995: By 1906, it was operating over the 14 miles between Santa Cruz and Swanton and by 1908, it was operating between San Francisco and Tunitas Glen. Koch, 1991, 68: A Stanley Steamer served as bus between Swanton and Tunitas.

${ }^{119}$ Staff Writer, "Railroad Related: Closing Gap in Ocean Shore Road," San Francisco Call (San Francisco, CA), Jul. 19, 1908 provides an optimistic account of how the Ocean Shore Railroad would be extended from Scott Creek to El Granada in San Mateo County; Additional resources available at http://www.santacruztrains.com.

${ }^{120}$ Cal Poly, 2011, 21: It was named for J.A. Folger, the "coffee king" of San Francisco and the first president of the Ocean Shore Railroad.

${ }_{121}$ Collins, 1995: The 26 miles in between were never completed.

122 See Appendix H: The Cal Barn: 100 Years of Universities in the Coastal Region of Northern Santa Cruz County.
} 

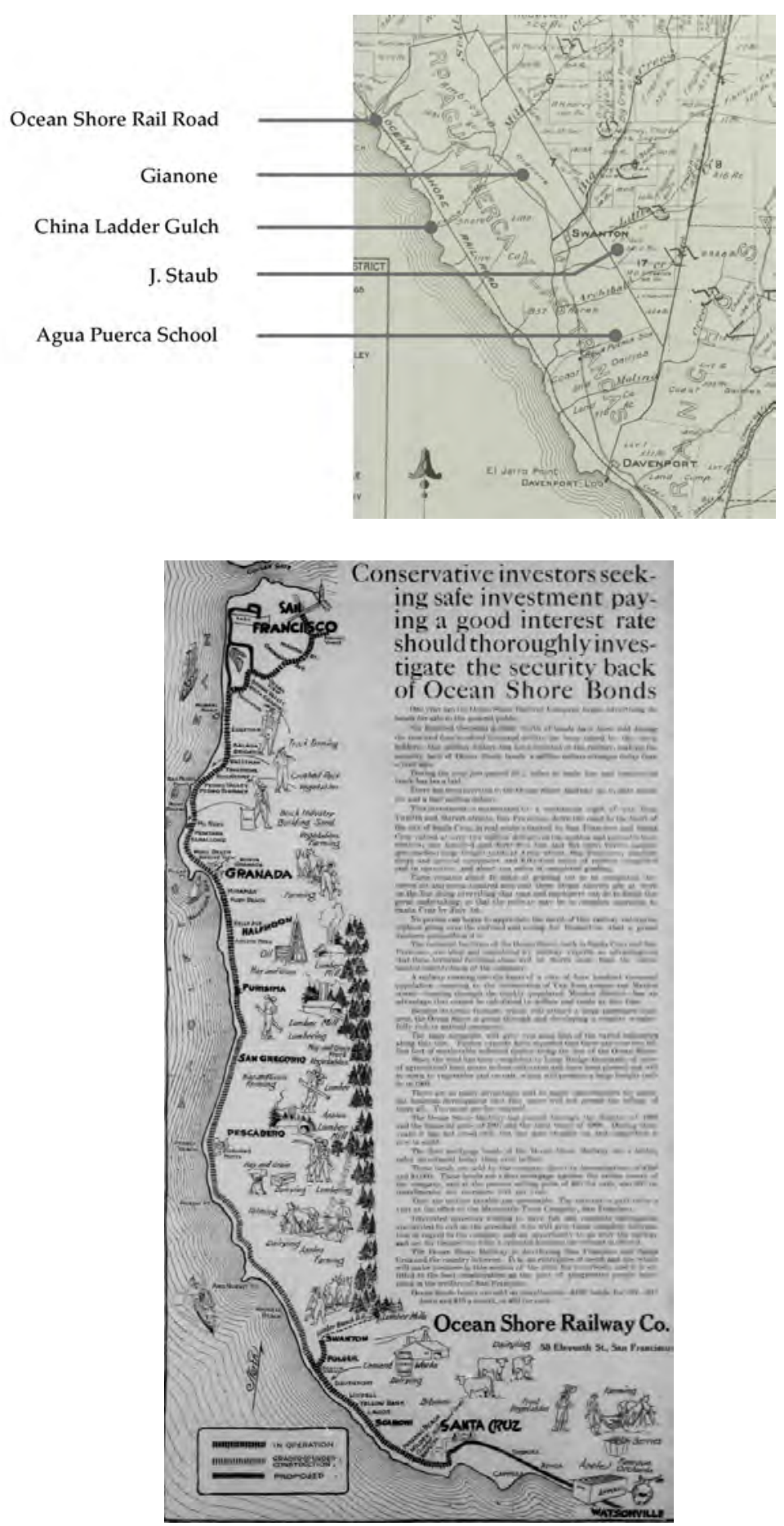

Figure 7: Ocean Shore Railroad. Top image: Official Map of the County of Santa Cruz, 1906, Sheet 4 Close Up. Courtesy Special Collections, University Library, University of California Santa Cruz. Official map of Santa Cruz County, 1906,.http://library.ucsc.edu/maps/punnett-brothers-digitized-maps-of-santa-cruzcounty. Modified from original. Bottom image: Ocean Shore Advertisement 1909. Advertisement map of proposed railroad linking Santa Cruz/Swanton to San Francisco. Staff Writer, "Advertisement," San Francisco Call (San Francisco, CA), Jan. 4, 1909, http://cdnc.ucr.edu/cgibin/cdnc?a=d\&d=SFC19090104.2.47.2\&srpos=13\&e=04-01-1909----190-en--20--1--txt-txINOcean+Shore+Railway-ADVERTISEMENT---1909--\#. 


\section{Is it Scott's Creek or Scott Creek or Scotts Creek?}

Over time there has been debate about the correct name of Scott's/Scott/Scotts Creek and maps are a tool that can also be used to observe the change of the name. ${ }^{123}$ Present terminology is either Scott or Scotts Creek: (1) both variations are used by Cal Poly students, staff, and faculty; (2) there are organizations like the Scotts Creek Watershed Council; (3) major research works like West (2015) use Scott Creek; (4) USGS uses Scott Creek on its maps; and (5) current local and state signage on roads and beaches use Scott Creek (ex. Figure 8: Scott Creek Beach).

The following maps show examples of the changes in the name of Scott Creek. Though this may not appear to be important per se, it has become part of a local debate, particularly as to which form of the name is used in official government and Cal Poly documents, the naming of organizations (i.e. the Scotts Creek Watershed Council), research works, and the like. The different versions of the name and the ensuing debate over the correct version also provide a glaring example of both why this area's history needs to be documented and how maps can provide a "case" or possibly a way to document/observe the reason(s) why things may have become muddled. As mentioned

\footnotetext{
${ }^{123}$ The name of a creek may not seem like something that can be highly contentious. Local and federal government maps and signage record the creek as Scott Creek. Early land deeds, leases, and easements use Scott. Government and private surveyors have recorded different forms of the name. Familial records of Swanton residents and current long-term residents disagree about the name of the Creek: Scott or Scotts. Eventually this debate and discussions influenced the naming of the Scotts Creek Watershed Council.
} 
above, this is not the first time inconsistencies within the historical record are reflected and learned from maps. ${ }^{124}$

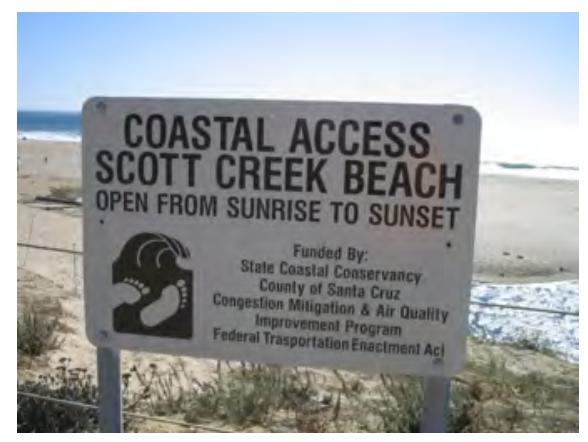

Figure 8: Scott Creek Beach. ${ }^{125}$

What is the name of the creek? The author is not here to choose sides but to uncover and share the information located. Using only maps as a guide, Table 2:

Scott's/Scotts/Scott Creek outlines the names used from 1868 to present. After the United States took possession of California, the 1868 General Land Office's basic general land survey of Swanton identified the creek as Scott's (Figure 9: General Land Office Records (GLO) Rancho Agua Puerca y Las Trancas Plat Map, 1868). In 188081, Thomas W. Wright, M.V. Bennett, and L.B. Healy created the oldest survey of land ownership of Santa Cruz County, in which they also indicated the name of the creek as Scott's Creek (Figure 10: Map Santa Cruz County, 1880-81 and Figure 11: Rancho Agua Puerca y las Trancas Eastern Boundary, Sheet 31, Map Santa Cruz County 1880-81). These 1880-81 maps show Scott's Creek, Staub's House, and Brown's House. The author must ask if the map makers may have used the possesive in their description

\footnotetext{
${ }^{124}$ The content on these maps provides additional historical context beyond a discussion of Scott Creek. These maps serve as a rich tool in an examination of Swanton.

${ }^{125}$ This was located on Yelp with no attribution, 2015.
} 
of the features. There is the possiblility that an owner named "Scott" may have had the water rights to the creek, hence the use of the possesive. ${ }^{126}$

Table 2: Scott's/Scotts/Scott Creek. This table lists out the years, maps, etc. and the name of the Creek respectively.

\begin{tabular}{|c|c|c|c|c|c|c|}
\hline Year & Map & $\begin{array}{l}\text { Scott's/ } \\
\text { Scott/ } \\
\text { Scotts } \\
\text { Creek }\end{array}$ & Surveyor(s) & $\begin{array}{l}\text { Contractor } \\
\text { Type }\end{array}$ & $\begin{array}{l}\text { Tile(s)/ } \\
\text { Sheet(s) }\end{array}$ & URL \\
\hline 1868 & $\begin{array}{l}\text { General } \\
\text { Land Office } \\
\text { Records } \\
\text { (GLO) } \\
\text { Rancho } \\
\text { Agua } \\
\text { Puerca y } \\
\text { Las Trancas } \\
\text { Plat Map }\end{array}$ & Scott's & $\begin{array}{l}\text { General } \\
\text { Land Office } \\
\text { Records } \\
\text { (GLO) }\end{array}$ & $\begin{array}{l}\text { Govern- } \\
\text { ment }\end{array}$ & & $\begin{array}{l}\text { http://www.gloreco } \\
\text { rds.blm.gov/details } \\
\text { /survey/default.asp } \\
\text { x?dm_id=380772\& } \\
\text { sid=h3jklvyg.mci\& } \\
\text { surveyDetailsTabl } \\
\text { ndex=1\#surveyDet } \\
\text { ailsTabIndex=1 }\end{array}$ \\
\hline $1880-81$ & $\begin{array}{l}\text { Map Santa } \\
\text { Cruz County }\end{array}$ & Scott's & $\begin{array}{l}\text { Thomas W. } \\
\text { Wright, M.V. } \\
\text { Bennett, and } \\
\text { L.B. Healy }\end{array}$ & Private & $\begin{array}{l}31,33, \\
34\end{array}$ & $\begin{array}{l}\text { http://library.ucsc.e } \\
\text { du/maps/map-of- } \\
\text { santa-cruz-county- } \\
1880-81\end{array}$ \\
\hline 1889 & $\begin{array}{l}\text { Official Map } \\
\text { of Santa } \\
\text { Cruz County }\end{array}$ & Scotts & $\begin{array}{l}\text { Andrew } \\
\text { Jackson } \\
\text { Hatch }\end{array}$ & Private & $\begin{array}{l}9,10 \\
17,18\end{array}$ & $\begin{array}{l}\text { http://library.ucsc.e } \\
\text { du/maps/official- } \\
\text { map-of-santa-cruz- } \\
\text { county-full-map- } \\
\text { with-index-of-tiles }\end{array}$ \\
\hline 1902 & $\begin{array}{l}\text { Santa Cruz } \\
\text { Quadrangle }\end{array}$ & Scott & $\begin{array}{l}\text { United } \\
\text { States } \\
\text { Geological } \\
\text { Service } \\
\text { (USGS) }\end{array}$ & $\begin{array}{l}\text { Govern- } \\
\text { ment }\end{array}$ & & $\begin{array}{l}\text { http://ims.er.usgs.g } \\
\text { ov/gda_services/d } \\
\text { ownload?item_id= } \\
5683183\end{array}$ \\
\hline 1906 & $\begin{array}{l}\text { Official Map } \\
\text { of the } \\
\text { County of } \\
\text { Santa Cruz }\end{array}$ & Scotts & $\begin{array}{l}\text { Punnett } \\
\text { Brothers }\end{array}$ & Private & 1,4 & $\begin{array}{l}\text { http://library.ucsc.e } \\
\text { du/maps/punnett- } \\
\text { brothers-digitized- } \\
\text { maps-of-santa- } \\
\text { cruz-county }\end{array}$ \\
\hline 2012 & $\begin{array}{l}\text { USGS US } \\
\text { Topographic } \\
\text { Map }\end{array}$ & Scott & $\begin{array}{l}\text { United } \\
\text { States } \\
\text { Geological } \\
\text { Service } \\
\text { (USGS) }\end{array}$ & $\begin{array}{l}\text { Govern- } \\
\text { ment }\end{array}$ & & $\begin{array}{l}\text { http://www.usgs.go } \\
\text { v/pubprod/maps.ht } \\
\mathrm{ml}\end{array}$ \\
\hline
\end{tabular}

${ }^{126}$ Could "Scott" have referred to Hiram Scott, the namesake of the City of Scotts Valley, Santa Cruz County? A review of the deeds and leases at that time may show something to the effect. 


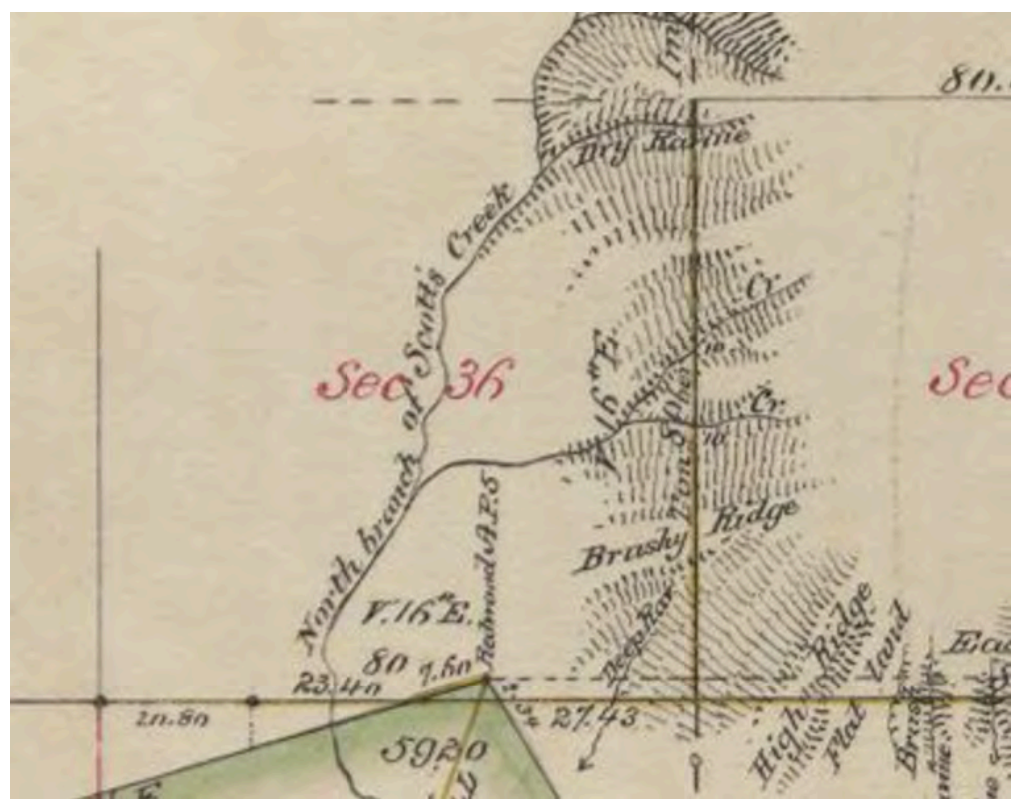

Figure 9: General Land Office Records (GLO) Rancho Agua Puerca y Las Trancas Plat Map, 1868. A close up of this map identifies Scott's Creek, United States Department of Interior, Bureau of Land Management, General Land Office Records, DM ID 380771, Lauren Upson (Surveyor General), 1868, http://www.glorecords.blm.gov/details/survey/default.aspx?dm_id=380772\&sid=h3jklvyg.mci\&surveyDetails Tablndex=1\#surveyDetailsTablndex=1. 

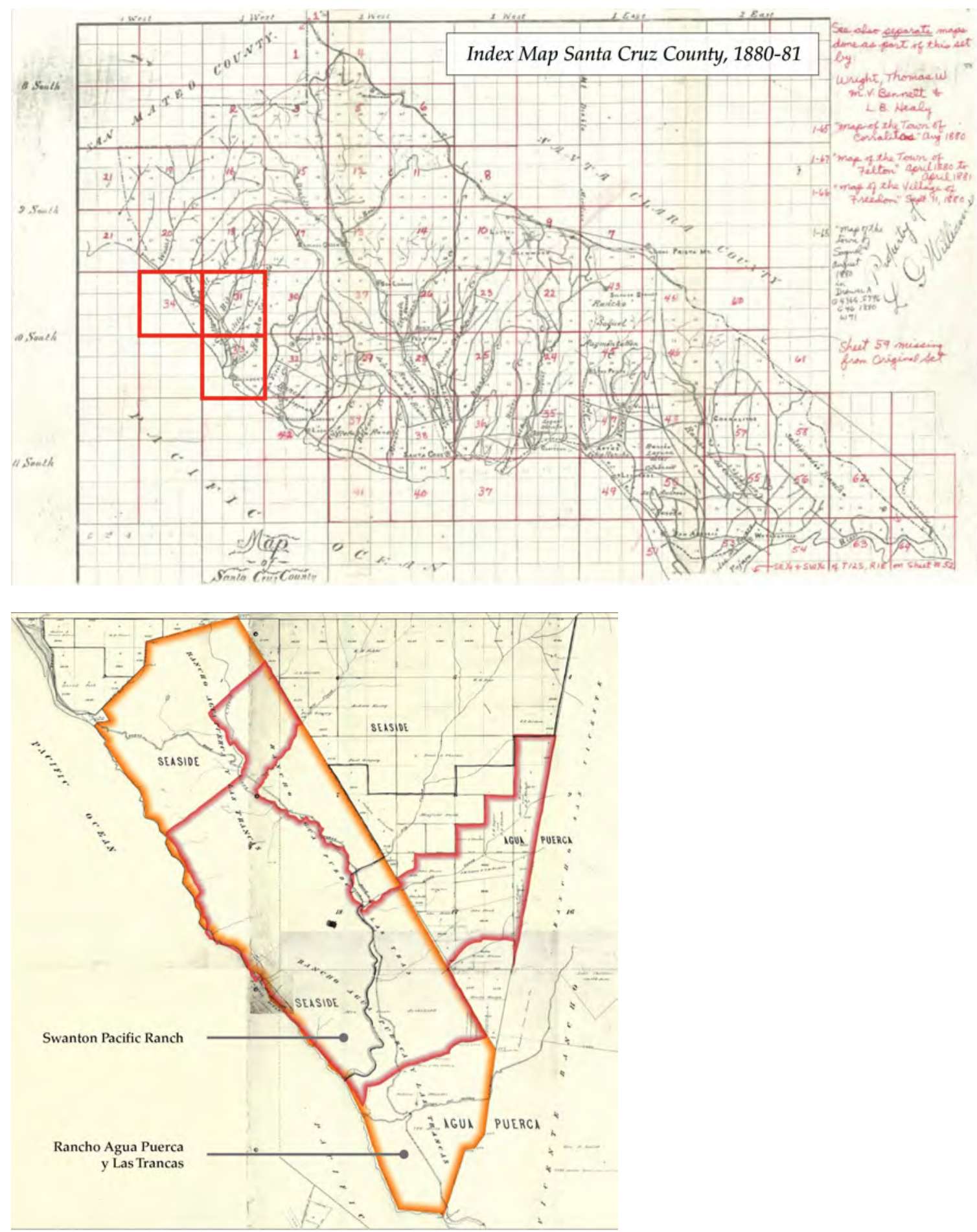

Figure 10: Map Santa Cruz County, 1880-81. The top image provides a slightly different view of the Thomas W. Wright, M.V. Bennett, and L.B. Healy survey with the Rancho's corresponding sheets (31, 33, and 34) outlined in red. The bottom image is a compilation of Sheets 31, 33, and 34, Map Santa Cruz County, 1880-81. Rancho Agua Puerca y las Trancas is outlined in orange on this map, and Swanton Pacific Ranch is outlined in red. Physical features include Mill Creek, Laurel, Coast Road and Scott's Creek. Special Collections, University Library, University of California Santa Cruz. Map of Santa Cruz County, 1880-81. http://library.ucsc.edu/maps/map-of-santa-cruz-county-1880-81. Modified from the original. 


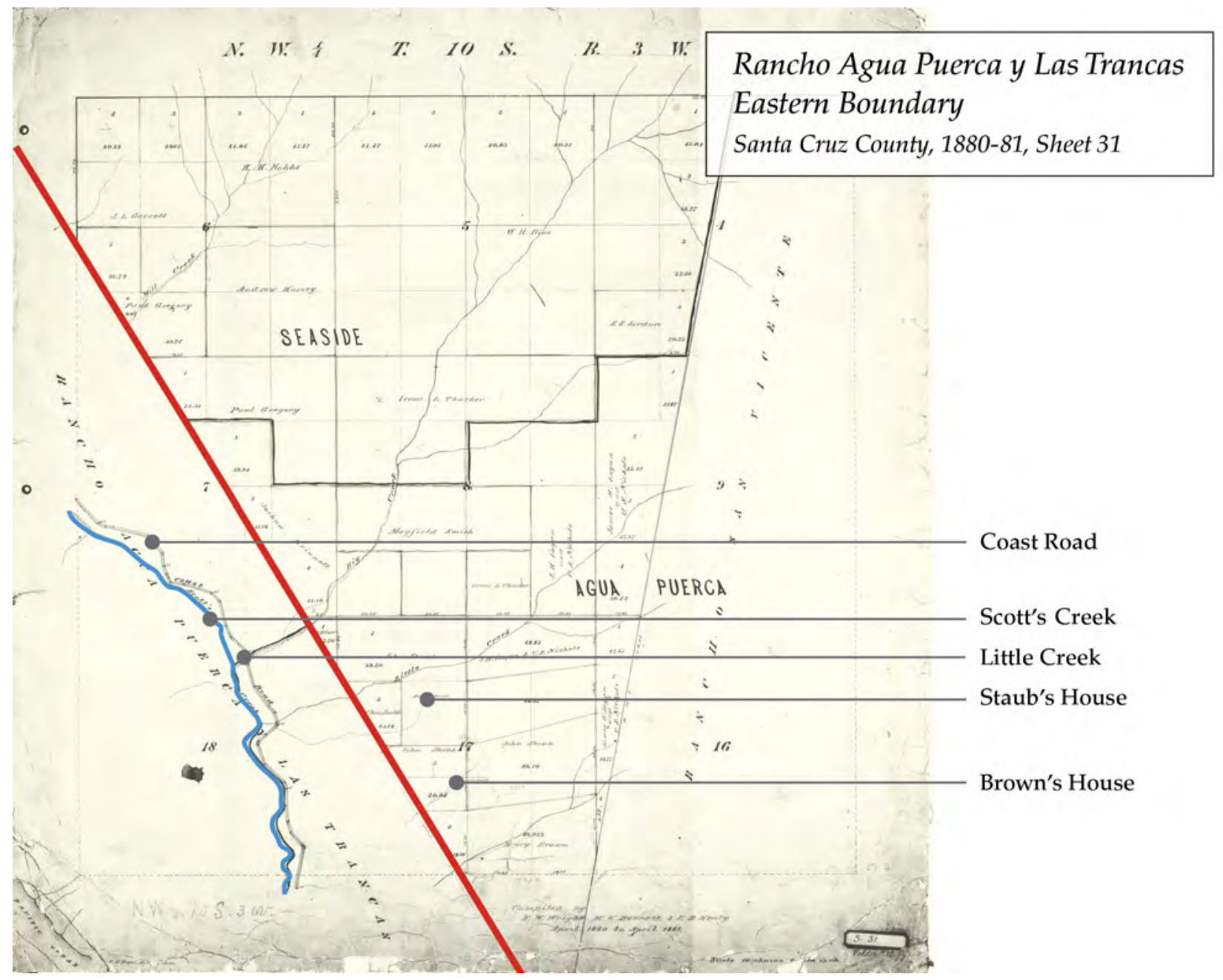

Figure 11: Rancho Agua Puerca y las Trancas Eastern Boundary, Sheet 31, Map Santa Cruz County 1880-81. Physical features include Mill Creek, Little Creek, Scott's Creek, Coast Road, Seaside School, Staub's house, Brown's house. Examples of owners listed on the map include: W. H. Bias, Henry Brown, W.B. Carr, J. L. Garrett, Paul Gregory, Joshua Grinnezz, Andrew Harvey, H. H. Hobbs, S. S. Jordan, James H. Logan and U.S. Nichols, Chase Smith, Mayfield Smith, John Staub, and Isaac L. Thurber. Courtesy Special Collections, University Library, University of California Santa Cruz. Map of Santa Cruz County, 1880-81.

http://library.ucsc.edu/maps/map-of-santa-cruz-county-1880-81. Modified from the original.

In 1889, Andrew Jackson Hatch was contracted to create the Official Map of Santa Cruz County (the Tile Index is seen in Figure 12: Official Map of Santa Cruz County, 1889, Tile Index). The property boundaries and ownership for Santa Cruz County are 
evident in the map, as are roads, Rancho boundaries, railroads, school districts, and more, including Scotts Creek (Figure 13: Official Map of Santa Cruz County, 1889, Tile

9).

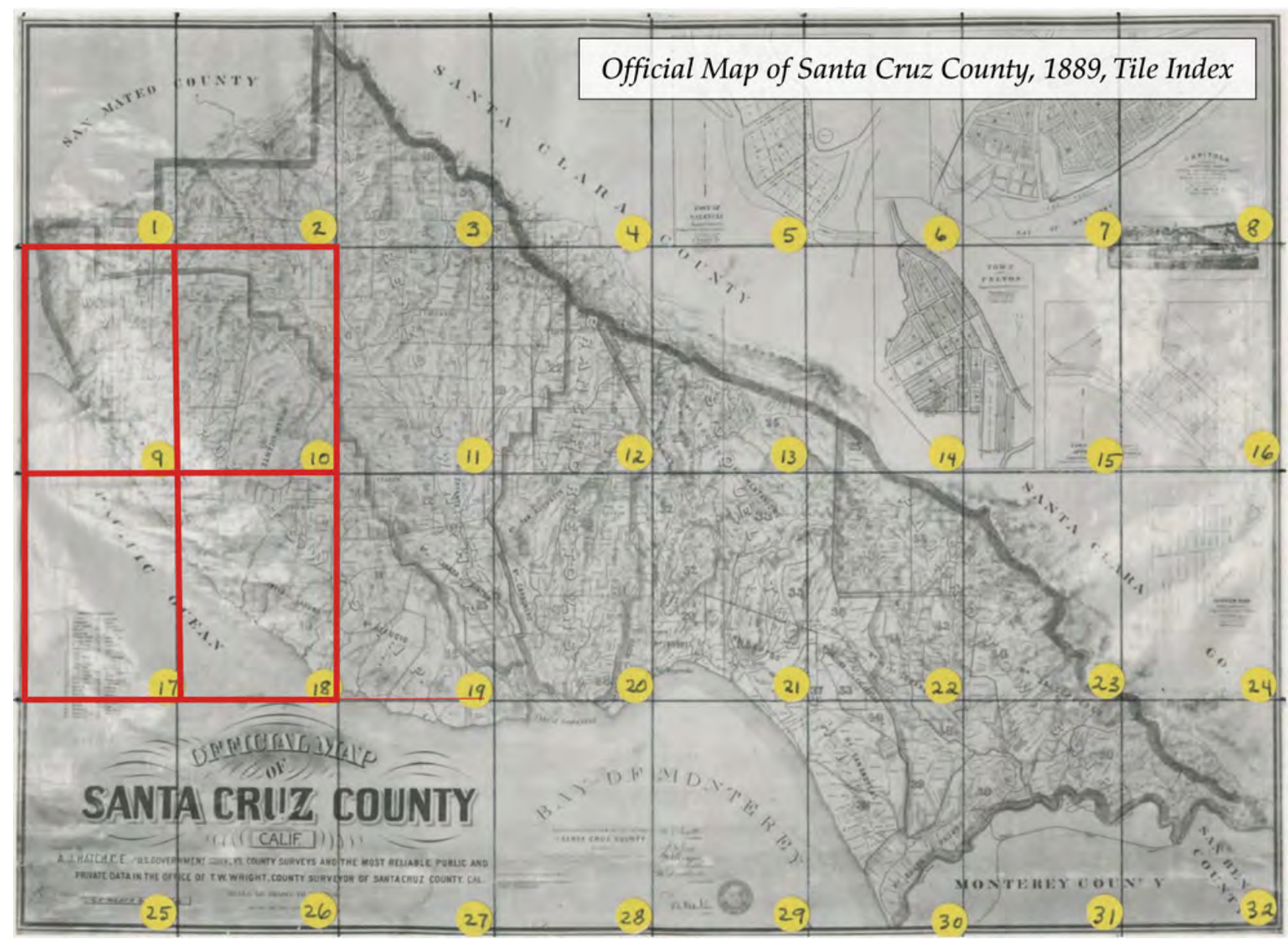

Figure 12: Official Map of Santa Cruz County, 1889, Tile Index. Andrew Jackson Hatch is responsible for creating the Official Map of Santa Cruz County. It shows property boundaries and ownership for Santa Cruz County. It also shows roads as they were in 1889 as well as Rancho boundaries. Railroads are shown, school districts are identified, and more. The red indicates the four sheets of this set of tiles that cover the Swanton area. Courtesy of Special Collections, University Library, University of California Santa Cruz. Official map of Santa Cruz County, 1889.

http://library.ucsc.edu/maps/official-map-of-santa-cruz-county-full-map-with-index-of-tiles. Modified from the original. 


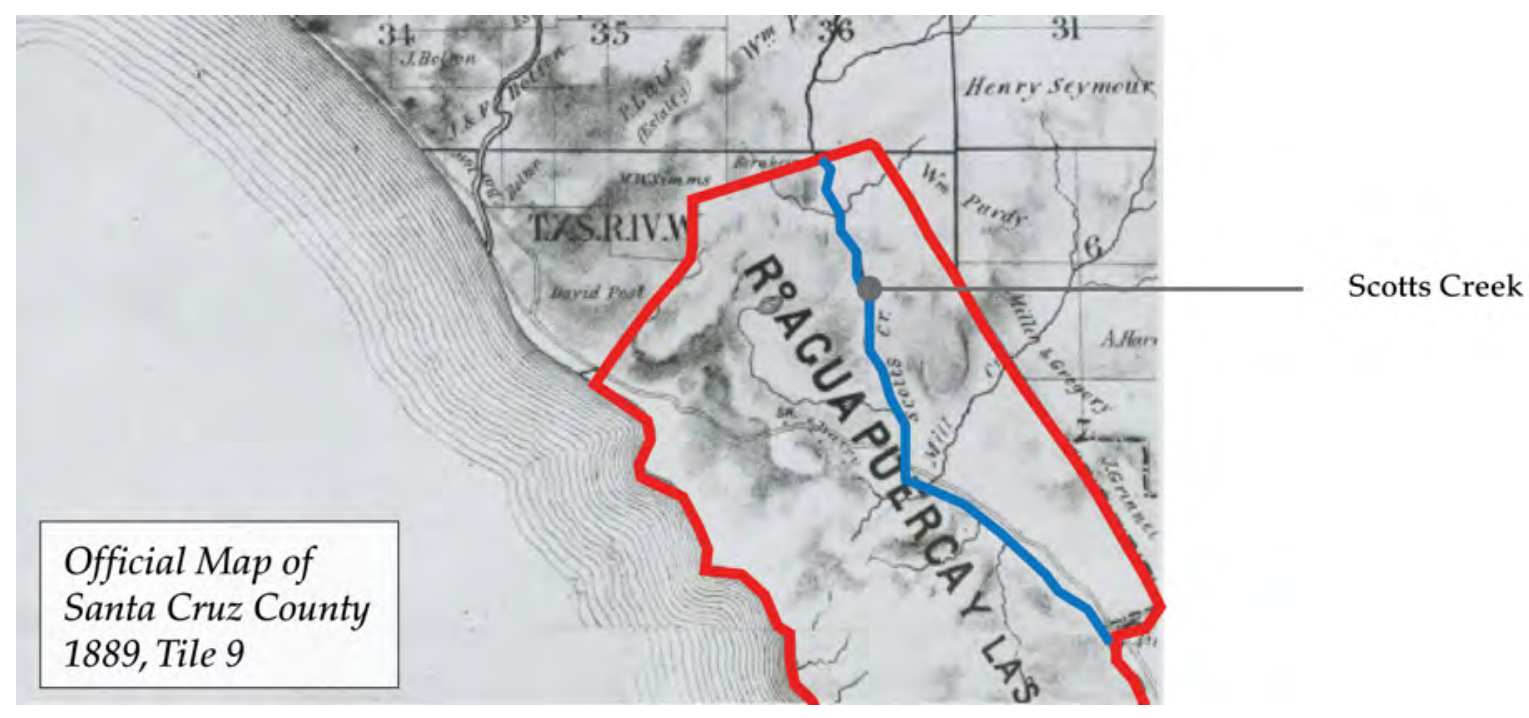

Figure 13: Official Map of Santa Cruz County, 1889, Tile 9. This close up of Tile 9 presents physical features including Scotts Creek and Mill Creek. Courtesy of Special Collections, University Library, University of California Santa Cruz. Official map of Santa Cruz County, 1889.

http://library.ucsc.edu/maps/official-map-of-santa-cruz-county-full-map-with-index-of-tiles. Modified from the original.

Figure 14, the United States Geological Service (USGS), 1902, Santa Cruz

Quadrangle, also features the creek and names it Scott Creek. Then in 1906, a private contract company, the Punnett Brothers, was hired to map the County of Santa Cruz (Figure 15: Official Map of the County of Santa Cruz, 1906), describing the feature as Scotts Creek (Figures 16: Official Map of the County of Santa Cruz, 1906, Sheet 4 Magnified). The Punnett Brothers follow the same naming protocol as the 1889 surveyor, another private contractor, instead of following the government's protocol. Fast forwarding to present day, the United States Geological Service continues to use Scott (see Figure 17: United States Geological Service (USGS), The National Map, May 17, 2012, USBG 10S EG 6912 0063). 


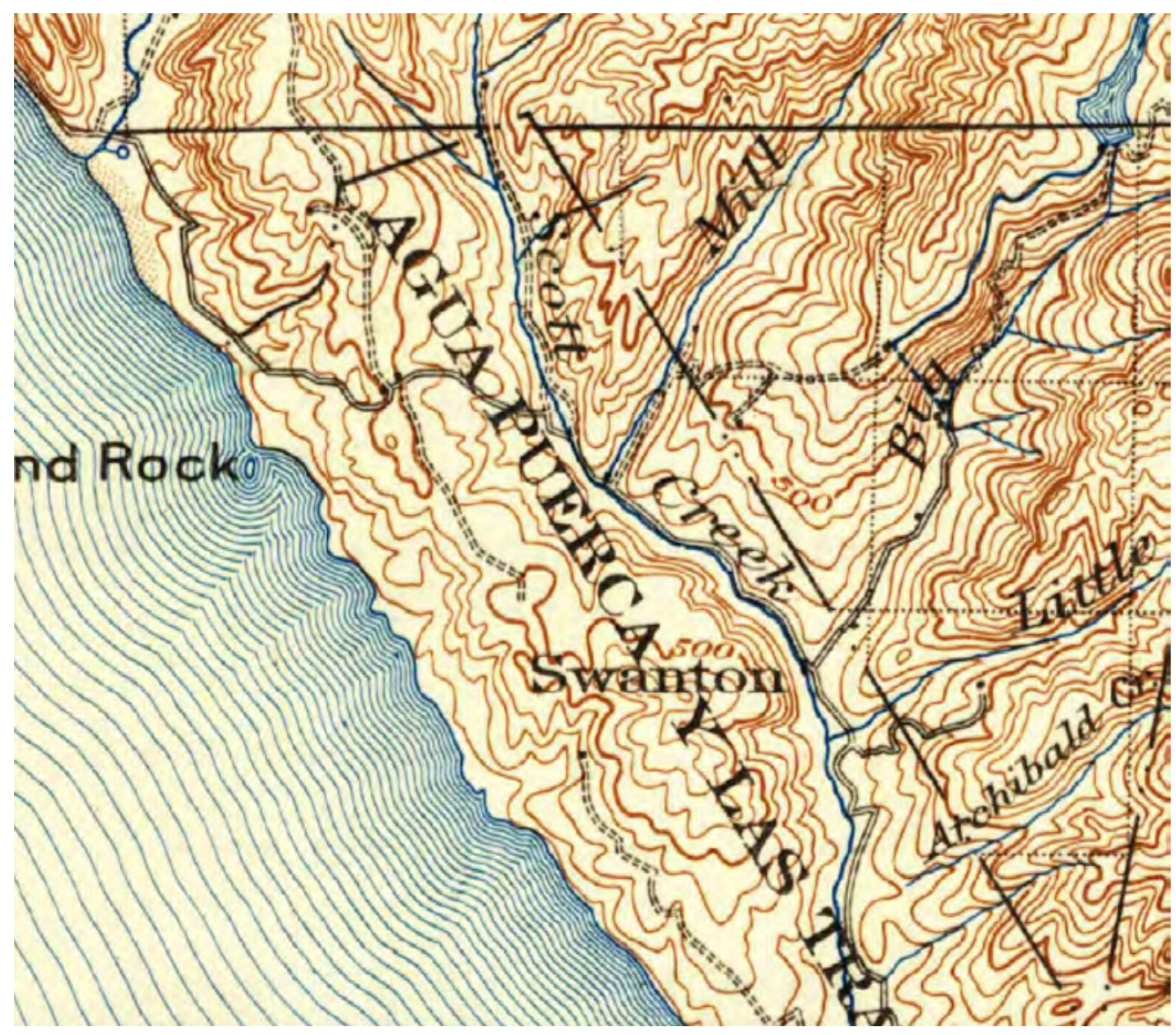

Figure 14: United States Geological Service (USGS), 1902, Santa Cruz Quadrangle. Close up of Santa Cruz quadrangle [map]. United States Department of the Interior. Scott Creek is identified as one of the features. 


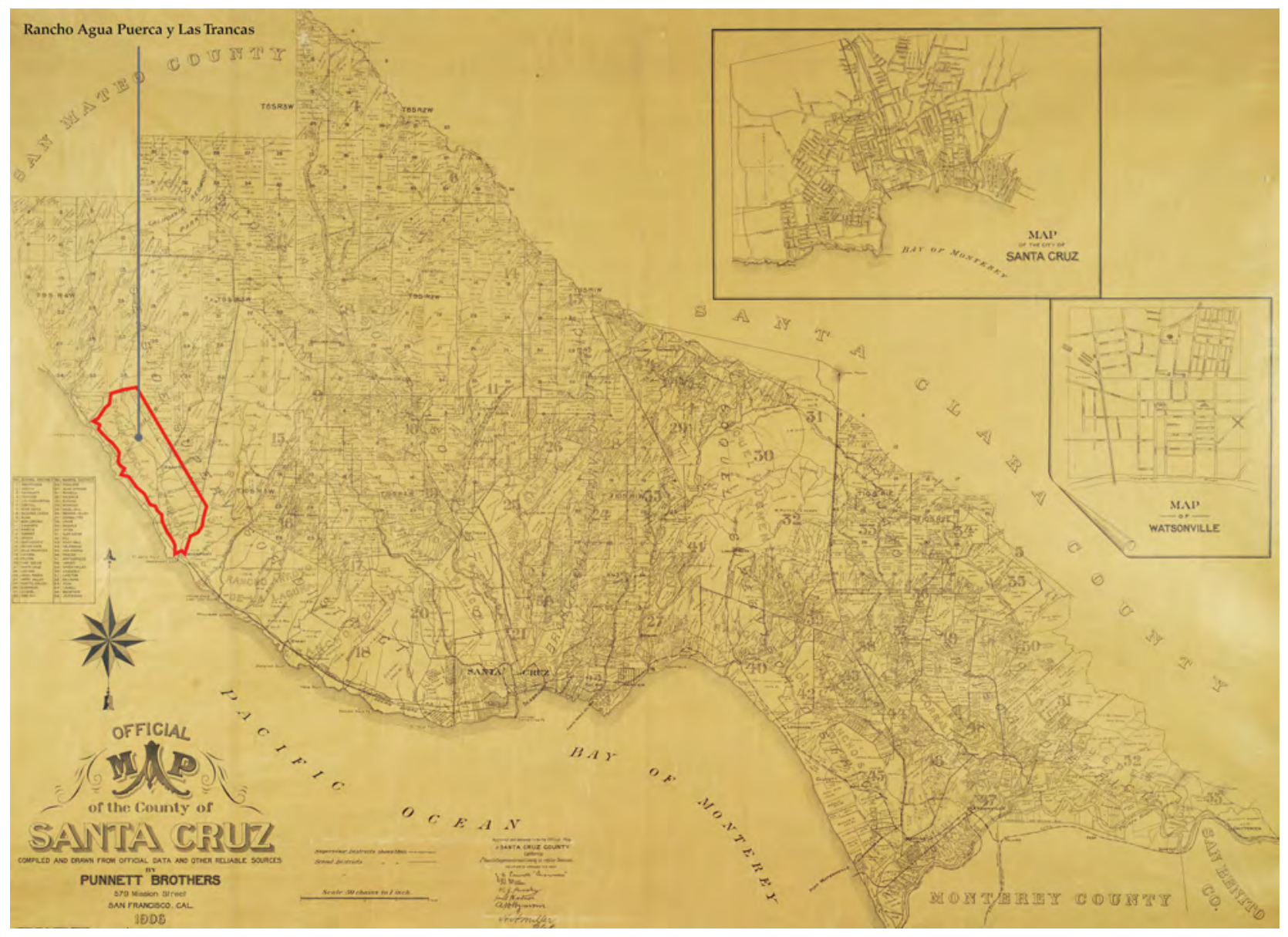

Figure 15: Official Map of the County of Santa Cruz, 1906. The Punnett Brothers created this Official Map of Santa Cruz County. It shows roads, railways, landownership with names, acreages, township and range, school and supervisors districts, and ranchos. The Rancho is outlined in red. Scale: ca. 1:39,600 Location: Davenport; Santa Cruz; Capitola; Aptos; Bonny Doon; Corralitos; Watsonville; Freedom; Santa Cruz (county) Courtesy of Special Collections, University Library, University of California Santa Cruz. Official Map of the County of Santa Cruz, 1906.

http://library.ucsc.edu/maps/punnett-brothers-digitized-maps-of-santa-cruz-county. Modified from the original. 


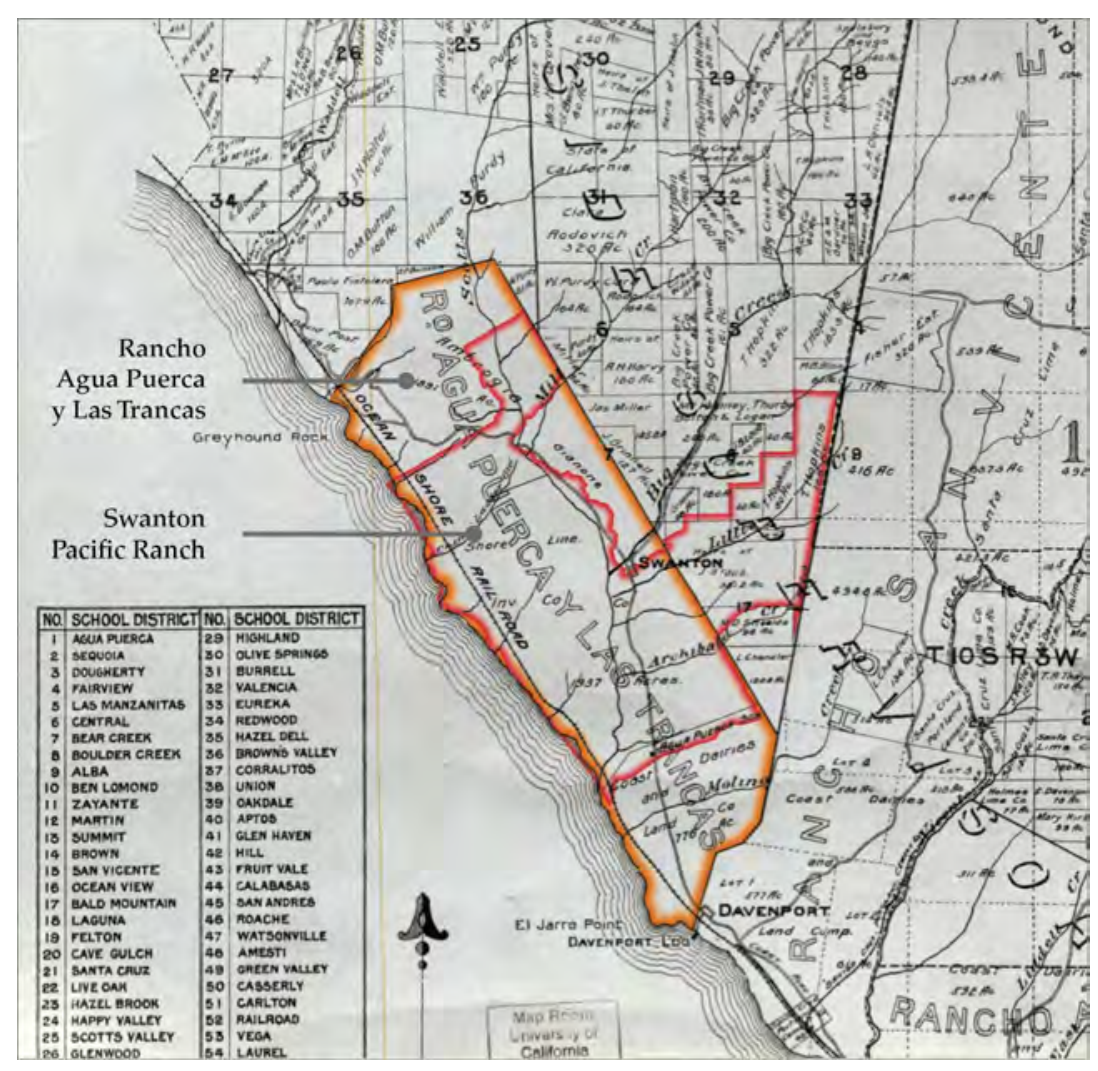

Figure 16: Official Map of the County of Santa Cruz, 1906, Sheet 4 Magnified. The creek is identified as Scotts. Courtesy Special Collections, University Library, University of California Santa Cruz. Official map of Santa Cruz County, 1906.

http://library.ucsc.edu/maps/punnett-brothers-digitized-maps-of-santa-cruz-county. Modified from the original. 


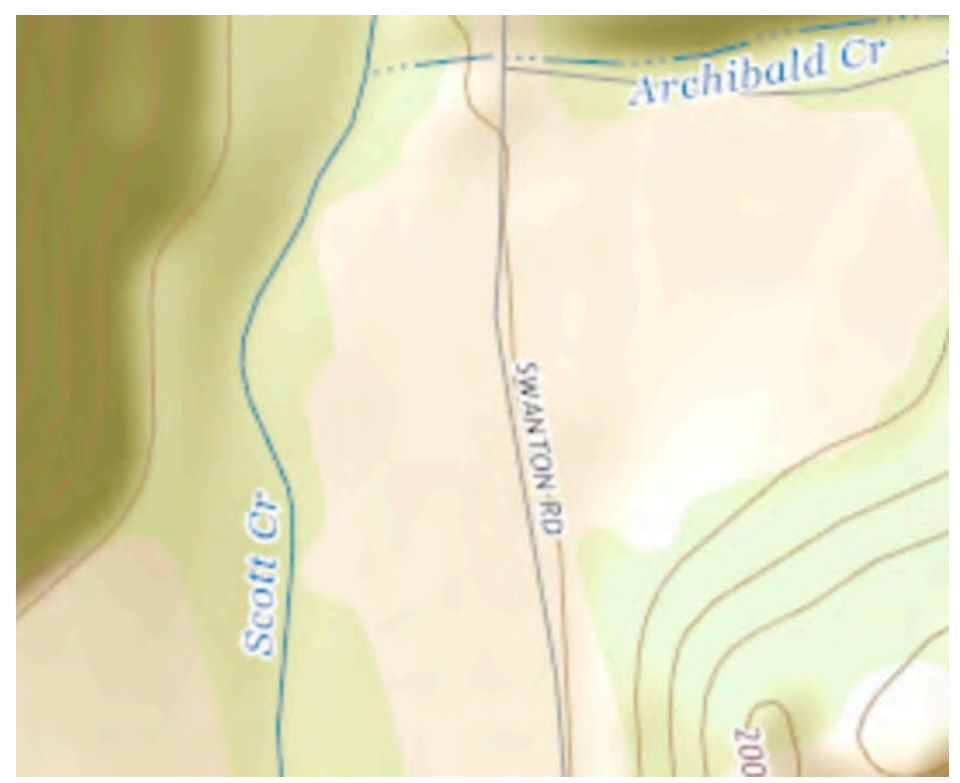

Figure 17: United States Geological Service (USGS), The National Map, May 17, 2012, USBG 10S EG 6912 0063. Close up of Santa Cruz quadrangle [map]. The image identifies the water feature as Scott. United States Department of the Interior.

Why Scott's Creek became Scotts Creek in privately contracted maps is not clear.

One scenario: It is possible that Wright, et al. $1880-81$ followed the 1868 government maps, Hatch in 1889 referred to these previous maps keeping the 's' but losing the possessive. Then subsequent government surveyors recognizing that the original use of Scott's indicated ownership/water rights, and in 1902 dropped the possessive (Scott's to Scott). Investigation of the history of cartography and differences between government surveyors' and private contractors' best practices might provide information that sheds light on the change of the name over time. ${ }^{127}$

${ }^{127}$ Whether a general pattern will emerge or if it will be specific to this case/creek remains to be seen. 
Viewing Land Use Through Imagery

Land use varied from the personal to commercial. The vegetation itself can be broken into four categories: forestland, rangeland, brush land, and cropland. ${ }^{128}$ The land use of Swanton can be studied in a number of ways. One way would be by creating a timeline of owners and of land use based on census and agricultural census; another would be by the setting of an interactive map or a table of owners with cost of land sold or leased. ${ }^{129}$ Another tool in studying the land use of Swanton is imagery (see Table 3:

\section{Swanton Pacific Ranch Historical Aerial Imagery).}

An early impact on Swanton land, between the 1900s and 1920s, was the clearcut logging of redwoods that supplied some of the lumber used to rebuild San Francisco after the 1906 earthquake. ${ }^{130}$ The San Vicente Lumber Company used shay engines to haul logs out of Little Creek and took over the Ocean Shore railroad line for logging purposes once the company went out of business in $1921 .{ }^{131}$

Smith's (1990), History of Swanton - Beginnings of Swanton, description of logging during that time period focused on the capital produced and is as follows:

\footnotetext{
${ }^{128}$ Cal Poly, "Nonindustrial Timber Management Plan (NTMP) Section III - Plan Addendum," Swanton Pacific Ranch, 2008, http://spranch.calpoly.edu/files/Swanton_NTMP/20080610_1-07NTMP020SCR_Sec3.pdf.

${ }^{129}$ Kim Stoner, the son of former resident Marie Pini Stoner, has collected all the deeds, leases, and easements of Swanton from government agencies over the years. His contribution to the history of the area is this collection. A possible step could be the creation of a map synthesizing the information he has collected. The deed and lease information includes names of owners, leasers/purchasers, easements, boundaries, costs incurred, etc. It would also be an interesting social study to see who owned the land and who worked it; who inhabited the land and who was a tenant; Marie Pini Stoner lived in Swanton specifically at her family's farm, "Siberia," from 1929 until 1940. Marie Pini Stoner, interview with author, Feb. 1, 2014.

${ }^{130}$ Recently, Brian Dietterick, Swanton Pacific Ranch Director, has asked that this comment be changed to reflect the fact that the wood was utilized in locations that included but were not limited to San Francisco. Personal communication, to author from Steve Auten, October 24, 2015.

${ }^{131}$ Cal Poly, "Swanton Pacific Ranch Management Plan," 2004, 22.
} 
The San Vicente Lumber Company logged from 1905 to 1923 in the hills behind Swanton and had the Ocean Shore Railroad haul the logs to their mill in Santa Cruz. Much of the redwood was used to rebuild San Francisco after the 1906 earthquake and fire. ${ }^{132}$

\title{
Big Creek Lumber Company's 1991 description of logging focuses on the practices
}

\author{
of the time period and their results:
}

\begin{abstract}
This clear-cut yielded an even-aged stand of redwood and Douglas-fir. There are a few residual trees that for some reason were not cut in the original logging. Logging also took place during the 1950's on Scott Creek Stand using a partial-cut method. The logging was done by small tractor and resulted in a network of skid roads in the stand. According to the historical background for the Swanton Pacific Ranch Forestry Management Plan the logging was a high-grade selection, with the poor quality trees left as residual trees. Burning followed the logging in parts of the stand to remove the unwanted limbs and resulted in severe damage to some of the residual trees.
\end{abstract}

In addition to logging, agriculture has long been a part of the Ranch's land use.

Some of the historical structures on the Ranch are from dairy operations. A good portion

of the current Swanton Pacific rangeland was once under cultivation with orchards,

Brussels sprouts, and artichokes as well as strawberries. Smith's (1990), History of

Swanton - Agriculture, description is as follows:

Starting in the 1920's it was discovered that artichokes and Brussels sprouts grew well in the coastal area. Scott Creek was dammed and huge single cylinder gasoline engines were used to pump the water onto the upper terraces. There are the remnants of some twenty reservoirs and numerous gravity flow structures left on what is now rangeland. Some of the leading citizens of Santa Cruz spent their childhood here on windswept little farms with such nicknames as "Siberia" or "Poverty Flats". Some berries were also grown at this time.

In 1938 the Poletti and Morelli Families became the owners. World War II caused most of the tenant farmers to leave, ${ }^{133}$ and the Ranch was divided into three phases. There was a

\footnotetext{
${ }^{132}$ Sources specific to San Vicente include: (1) San Vicente Mill, Friday, September 19, 2014, Santa Cruz Trains: Railroads of the Monterey Bay, http://www.santacruztrains.com/2014/09/san-vicente-mill.html; (2) "Lumber Co. Purchases Ocean Shore Section," Mariposa Gazette LXVI(23), Oct. 30, 1920: "Railway is sold to San Vicente Lumber Co. who will operate train to transport logs from Swanton to its mill near the Santa Cruz city Limits."

${ }^{133}$ Italians that were not US citizens were seen as a threat and required to move into town and to live on the non-ocean side of Mission Street (a.k.a. Highway 1). Marie Pini Stoner's family owned a house on the "wrong" side of Mission Street. Their house was in the same place as the present McDonalds. She and her siblings (all US citizens) would go over to maintain the family garden, while her parents (not yet citizens) would yell from the other side of Mission where they were living, to communicate instructions for maintaining the garden. Marie Pini Stoner, interview with author, Feb. 1, 2014. See Appendix B: Pini Ranch and Family for pictures of the family.
} 
Grade B dairy, a beef cattle operation, and row crops. Artichokes and Brussels sprouts being labor-intensive, a labor camp was established with mostly Filipino workers. John and Bob Musitelli took over the beef cattle at this time and, with a bulldozer and herbicide and fire, opened a lot of waste brush land. They had a cow-calf operation and used a jeep pickup with bale of hay very effectively as a saddle horse. The Grade B dairy left and the Musitelli's expanded their operation.

With the use of chicken manure and excellent water supply, the Ranch produced excellent crops of sprouts year after year.

Swanton Pacific Ranch consists of a diverse landscape, and during the late $20^{\text {th }}$ century, under Smith's ownership, and later Cal Poly's, there was a transition in land use. Swanton Pacific Ranch's diversity of resources is a great asset for educational purposes. Scott Creek, a year round stream that empties into the ocean, bisects the property. The elevation ranges from sea level at the estuary to around 1,200 feet on the ridge north of Little Creek. The land, cropland, forest, rangeland, and riparian, is managed in a holistic manner. Croplands are located primarily in the Scott Creek valley, with approximately 125 acres of irrigated land. Forest areas exist throughout the property and are made up of 80 year-old second-growth stands of redwood and Douglas-fir, resulting from logging from 1909 through 1921; some of the stands had additional logging continuing up through the 1970s. Forest areas are being managed commercially on an uneven-aged, sustained yield basis. The majority of the managed forest lies within the Little and Archibald Creek watersheds, both tributaries of Scott Creek. Today the managed rangeland accounts for 1200-1400 acres, primarily on bluffs on the ocean side of the Ranch. Riparian corridors exist along Scott Creek, Mill Creek, Little Creek, Archibald Creek, Queseria Creek, and some smaller unnamed drainages. These provide critical habitat to both Coho salmon and steelhead trout as do the wetlands at the mouth of Scott Creek. 
Utilizing maps and historic imagery to track ownership and conditions of the land can provide additional (but not necessarily continual) informational content over several decades. Table 3: Swanton Pacific Ranch Historical Aerial Imagery lists sources of digital historic imagery of Swanton Pacific Ranch. Figure 18: 1928 Swanton Aerial Imagery, Figure 19: 1928 and 1941 Swanton Aerial Imagery, Figure 20: 1943 Swanton Aerial Imagery, Figure 21: 1953 Swanton Aerial Imagery, Figure 22: 1956 Swanton Aerial Imagery, and Figure 23: 1975 and 2014 Swanton Aerial Imagery provide specific images that provide examples of land use from 1928 to 2014 . Reviews of these images can be used to investigate past conditions of the area. Examining this type of historical source can provide valuable data for making present land use policy.

Table 3: Swanton Pacific Ranch Historical Aerial Imagery. This is a list of sources of the historical aerial imagery available digitally, with coverage over Swanton Pacific Ranch ("partial coverage, primarily along the coast; $\dagger$ specifically in April of 1948, prior to the Pine Mountain Fire).

\begin{tabular}{|l|l|l|}
\hline Year & Source & URL \\
\hline $1928^{*}$ & $\begin{array}{l}\text { University of California Santa } \\
\text { Cruz (UCSC) Library }\end{array}$ & http://guides.library.ucsc.edu/maps/aerial \\
\hline $1941^{*}$ & UCSC Library & http://guides.library.ucsc.edu/maps/aerial \\
\hline 1943 & UCSC Library & http://guides.library.ucsc.edu/maps/aerial \\
\hline $1948 \dagger$ & UCSC Library & http://guides.library.ucsc.edu/maps/aerial \\
\hline 1953 & $\begin{array}{l}\text { United States Geological Survey } \\
\text { (USGS) Earth Explorer }\end{array}$ & http://earthexplorer.usgs.gov/ \\
\hline 1956 & UCSC Library & http://guides.library.ucsc.edu/maps/aerial \\
\hline 1968 & USGS Earth Explorer & http://earthexplorer.usgs.gov/ \\
\hline 1975 & UCSC Library & http://guides.library.ucsc.edu/maps/aerial \\
\hline 1984 & Imagery Laboratory (MIL) & http://www.library.ucsb.edu/mil \\
\hline
\end{tabular}




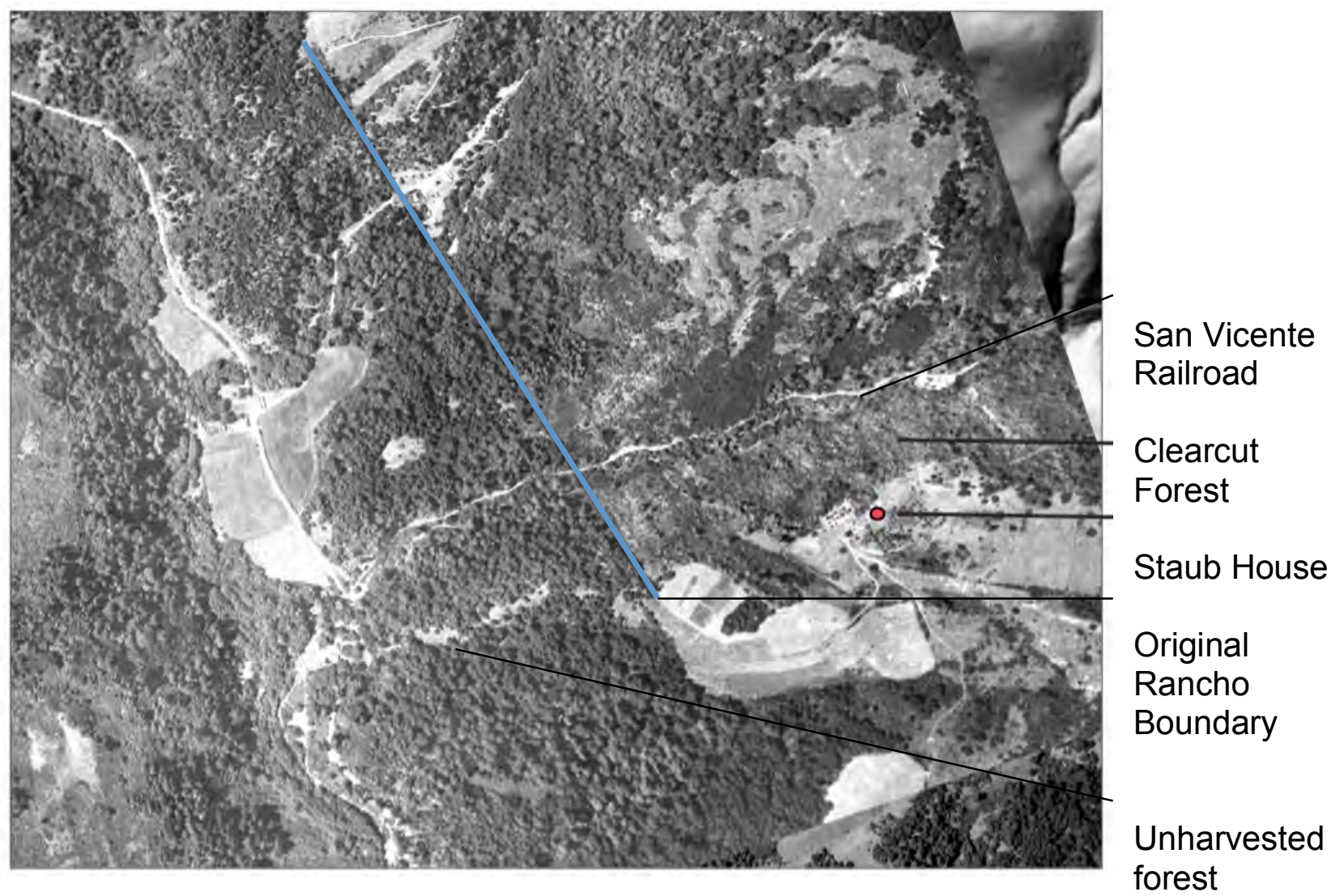

Figure 18: 1928 Swanton Aerial Imagery. The 1928 Imagery over Swanton Road and Little Creek. The effects of clearcutting and railroad transportation, the logging practice pre-WWII, are evident on the slopes of the Little Creek watershed close to the original Rancho line. It is interesting to note that at some point San Vincente Lumber Company bought property up to the Little Creek boundary. Courtesy of Special Collections, University Library, University of California Santa Cruz. Digitized Aerial Photos. http://guides.library.ucsc.edu/maps/aerial. Modified from the original. 


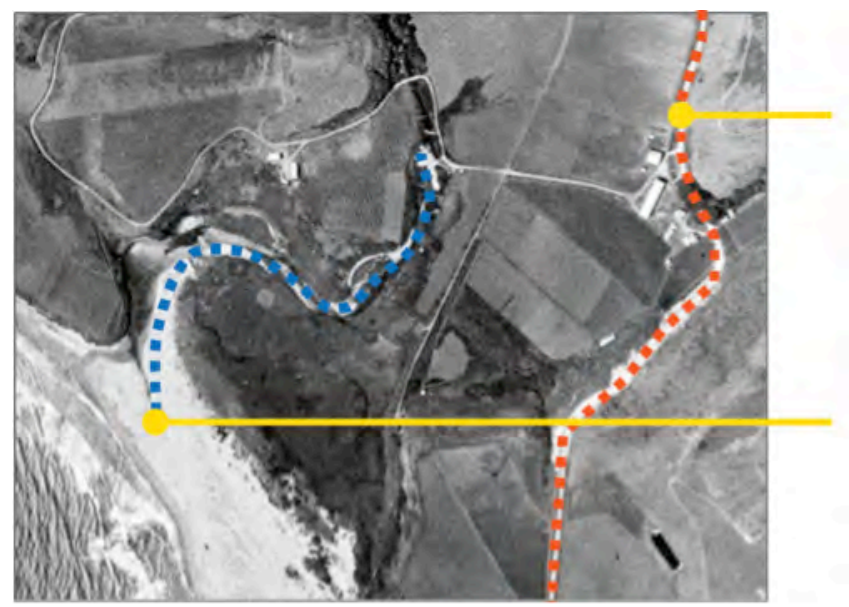

\section{Swanton Road / \\ HWY 1}

\section{Scott Creek}

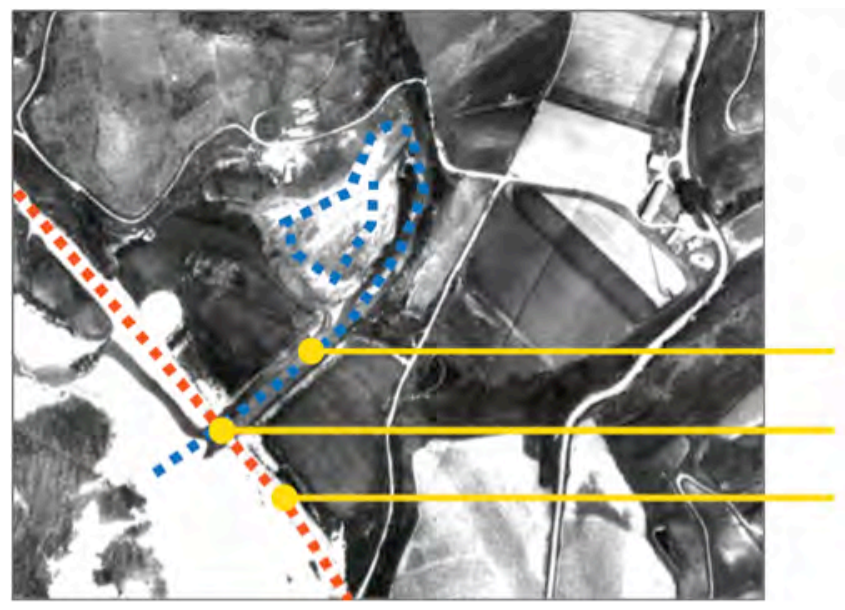

\section{Scott Creek}

\section{Bridge}

HWY 1

Figure 19: 1928 and 1941 Swanton Aerial Imagery. The 1928 Imagery (top) at the outlet of Scott Creek, prior to the construction of the Highway 1 bridge over Scott Creek. The blue dotted line delineates Scott Creek. The red dotted line delineates the "old" Highway 1. The 1941 imagery (bottom) is following the construction of the Scott Creek bridge and levees. The red line delineates the "new" Highway 1. The blue line delineates Scott Creek. Note the levee breach over crop fields (the circular blue dotted line of Scott Creek). Courtesy of Special Collections, University Library, University of California Santa Cruz. Digitized Aerial Photos. http://guides.library.ucsc.edu/maps/aerial. Modified from the original. 


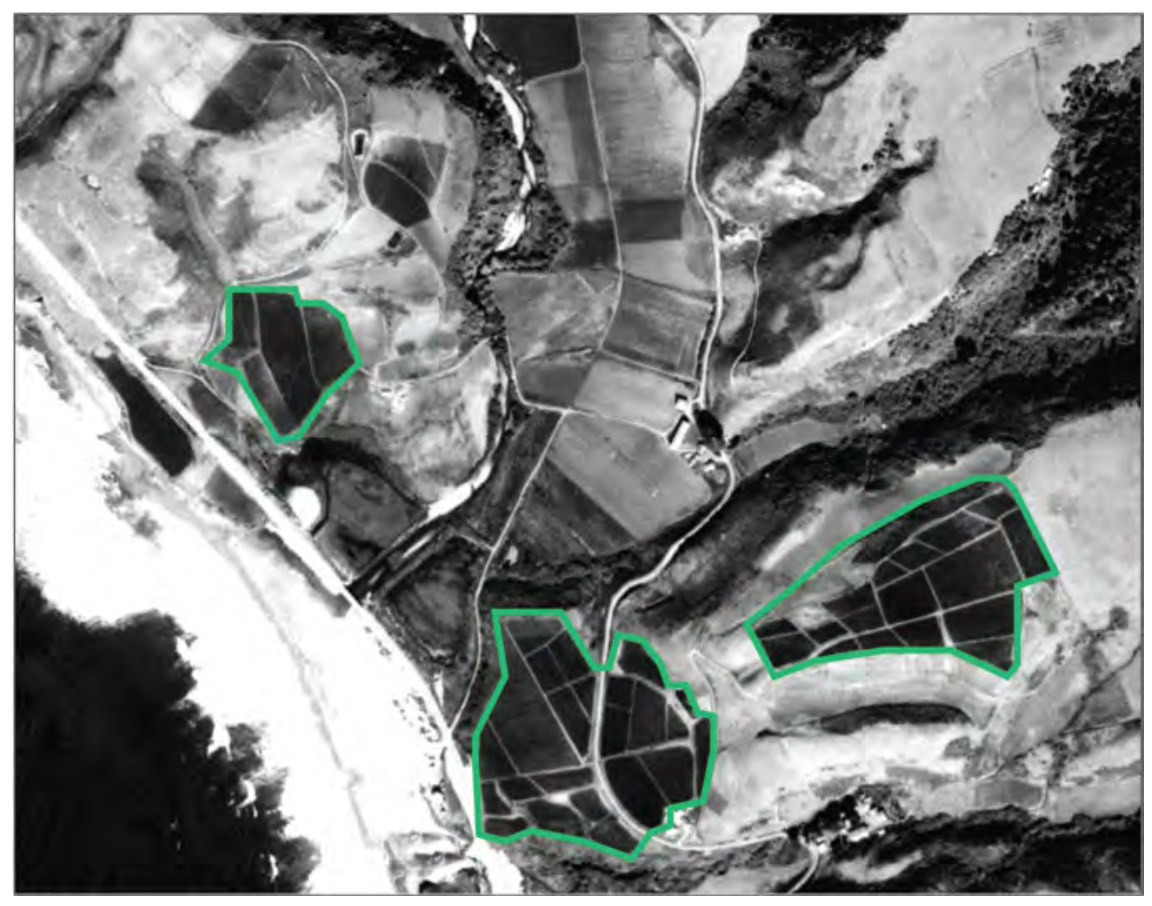

Figure 20: 1943 Swanton Aerial Imagery. This 1943 imagery shows artichoke fields planted along the marine terraces (green polygons). Cultivated between the 1940s-1950s, this land use eventually disappeared from the local landscape, and the land is again used for grazing. Courtesy of Special Collections, University Library, University of California Santa Cruz. Digitized Aerial Photos.

http://guides.library.ucsc.edu/maps/aerial. Modified from the original. 


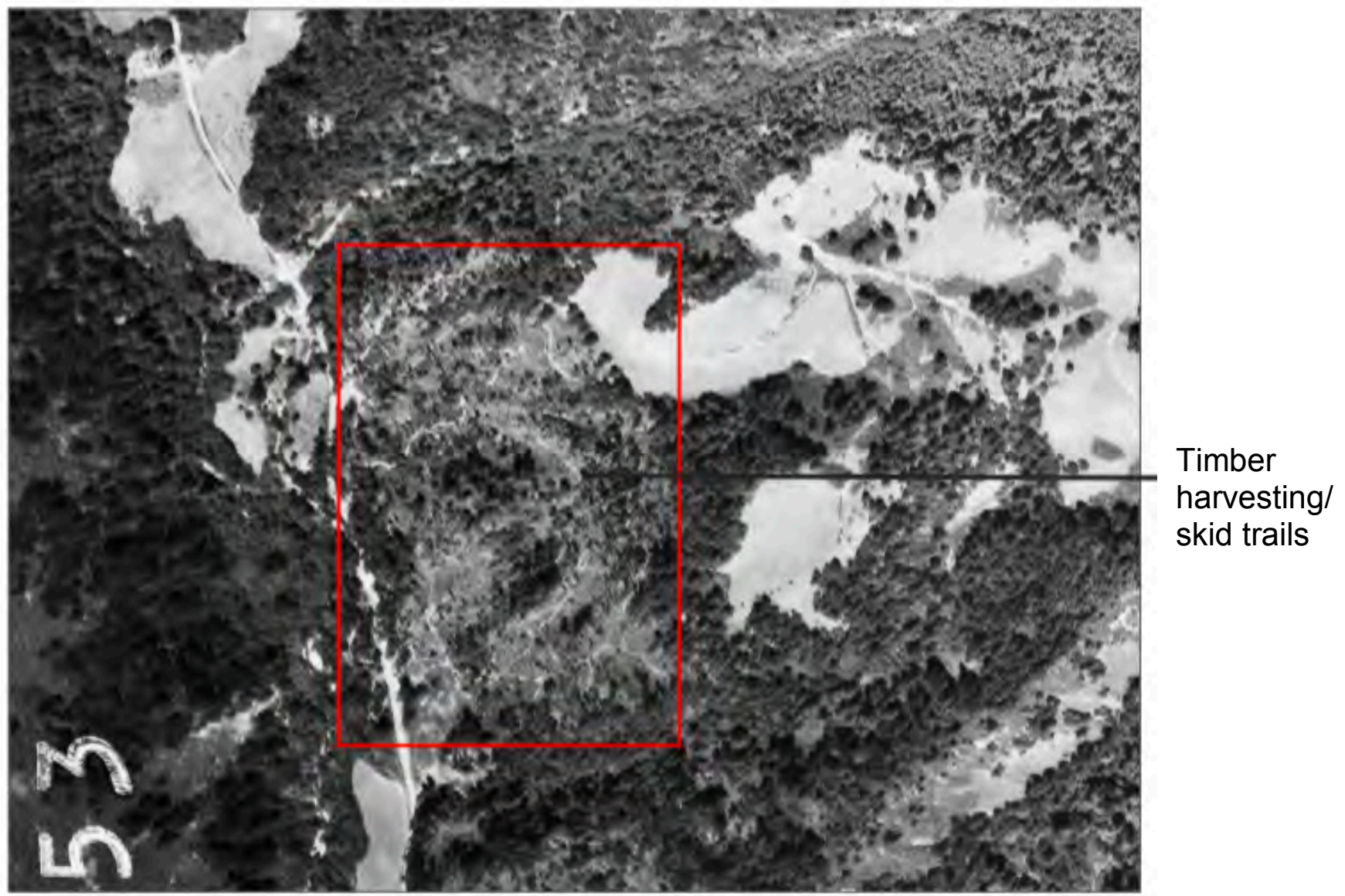

Figure 21: 1953 Swanton Aerial Imagery. The 1953 imagery over Swanton Road shows timber harvesting in the areas below the original Rancho line, not previously harvested. There is a clear network of roads and skid trails indicative of changes of logging practices to tractor logging post-WWII. The old growth harvested in the 50's and 60's was used to make split box products. ${ }^{134}$ Courtesy of Earth Explorer, United States Geological Survey. Satellite Images, Aerial Photographs, and Cartographic Products. http://earthexplorer.usgs.gov/. Modified from the original.

${ }^{134}$ Personal communication, to author from Steve Auten, October 24, 2015. 


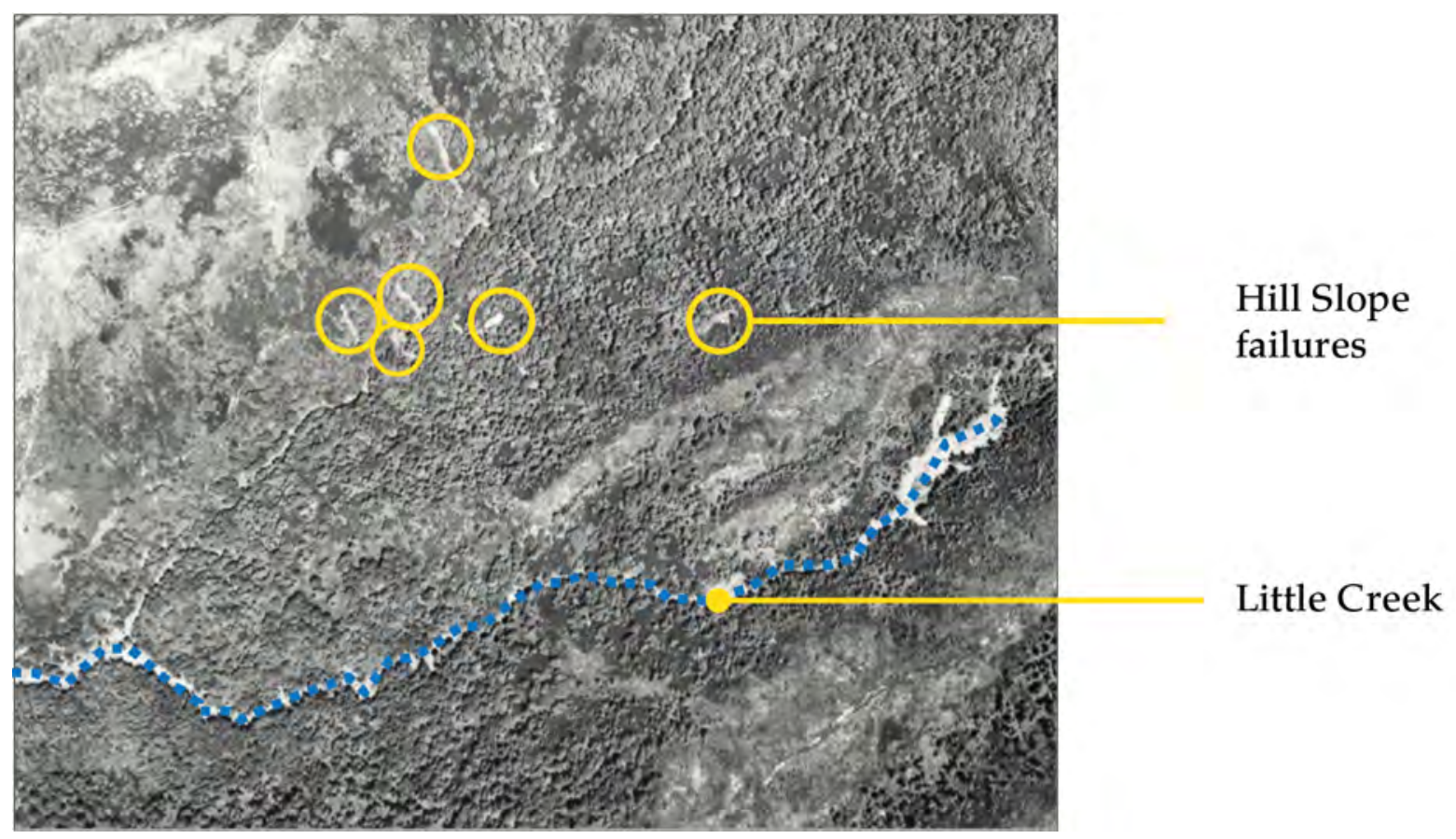

Figure 22: 1956 Swanton Aerial Imagery. The 1956 imagery over South Fork of Little Creek (blue dotted line) shows channel scour and landslides (indicated by the yellow circles) following the 1956 rain year. Courtesy of Special Collections, University Library, University of California Santa Cruz. Digitized Aerial Photos. http://guides.library.ucsc.edu/maps/aerial. Modified from the original. 

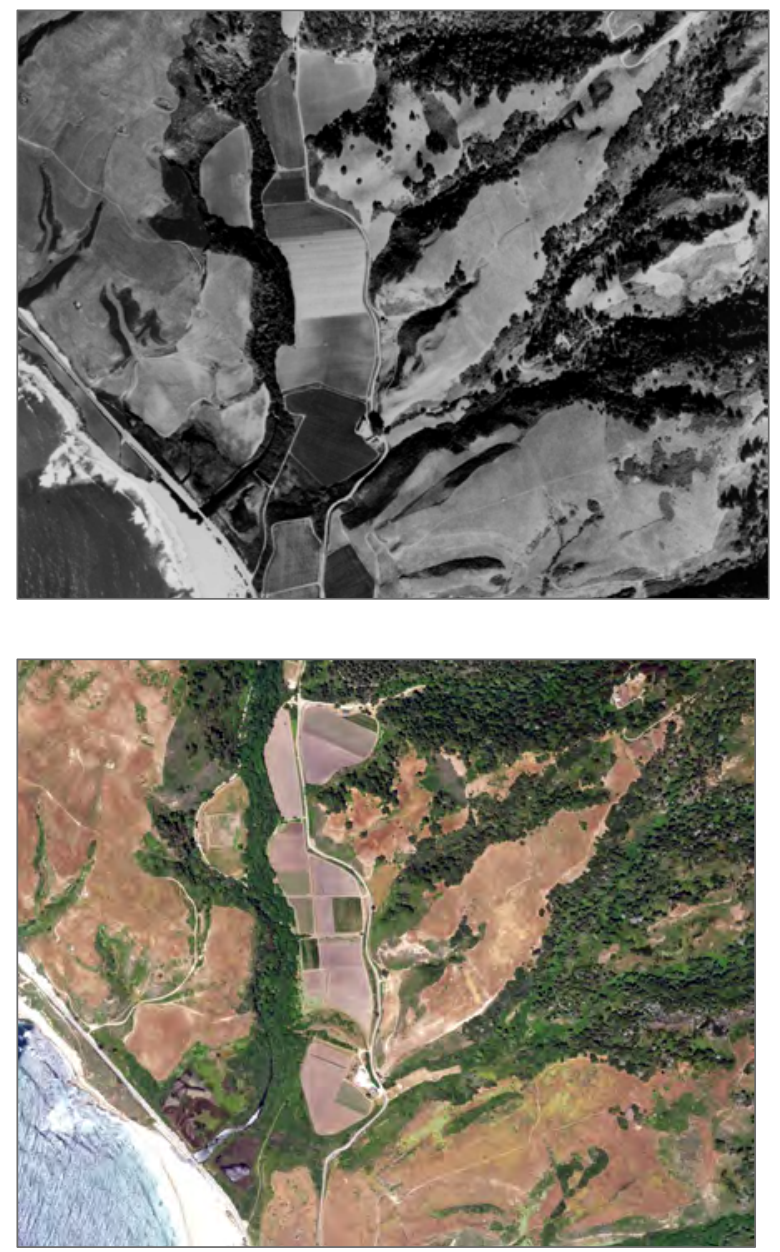

Figure 23: 1975 and 2014 Swanton Aerial Imagery. Aerial imagery over Swanton Road 1975 (top) and 2014 (bottom) shows evidence of grazing, cultivation, and timber. The landscape remains relatively unchanged. Croplands along Swanton Road remain in cultivation, with added setbacks for growth of the Scott Creek and Queseria Creek riparian corridors. Courtesy of USDA National Agriculture Imagery Program (NAIP).

The proceeding provides a basic historiography of Swanton during this time, and the factual inconsistencies (e.g. changes in the recording of a creek name and the location of a railroad) invite a discussion of how historical maps and pictures can be used to supplement documentation and memories of land use. ${ }^{135}$ The time period discussed in this chapter is an area ripe with possibilities for further exploration. Variations in the

${ }^{135}$ There are family diaries and other documents that are held privately, not available to the public, but have been cited as support for one specific form of the creek name. 
information regarding this era create an interesting historical puzzle; but the puzzle has missing pieces. Thus the puzzle is incomplete but an overall sense of the area and differences can be seen. The chapter above can be a springboard for more in depth discovery of Swanton's history during this period. 
Smith had the idea of acquiring as much of the land contained in the original Agua

Puerca y las Trancas land grant as possible, purchasing parcels to create Swanton Pacific Ranch over a 40 -year span. ${ }^{136}$ Smith gifted the Ranch to Cal Poly when he died on December 18, 1993. His instructions were to maintain Swanton Pacific Ranch as "a lab and a classroom for the College of Agriculture for 'Learn by Doing' forever." $\mathrm{He}$ wanted the property to remain a working ranch for instructional purposes, the railroad to remain intact and available to the public, and the remaining old growth redwoods to be left untouched. Though the Ranch is about 180 miles from Cal Poly, which some see as an obstacle, Smith saw it as a real opportunity for those who want or need hands-on ranching experience. (See Appendix E: School of Agriculture Work Day 1991 Agenda and Appendix G: Swanton Pacific Ranch Internship Information Packet.)

Smith's (1990), History of Swanton - The Swanton Pacific Years describes his initial engagement with the land as follows:

\begin{abstract}
When I bought the Ranch in 1978, I left the current tenants in place. I tried a small cow-calf operation on the Little Creek side, enough to realize it was a lot different from prunes and apricots. Then the Musitelli's retired and I hired a cowboy to run the cattle. We ran stockers at first and then went cow-calf, at the wrong time.
\end{abstract}

My vegetable tenant left. Believing there must be something else in Davenport's world than Brussels sprouts, I leased the land to a flower grower, who grew cut flowers and market peas. Although he tried hard, worked hard, and was conscientious to a fault, he could not make it.

\footnotetext{
${ }^{136}$ The following text is an amalgamation of numerous sources, the majority of sentences being paraphrased. All efforts were made to identify the source and indicate exact quotations. Unfortunately, the wording is often identical or extremely similar in sources, usually without any attribution, so that it is unclear from where information was collected, whose words were written first and who reiterated them, and what is considered "common knowledge." These sources include but are not limited to: Smith, 1990; Koch, 1991; Old Cal Poly Agriculture Website, September 1997, found in the Swanton Pacific Railroad Society Librarian's, Lou Haughney, papers, Box 2. Clark, 2008; and Cal Poly, 2011, 19-24.
} 
My cowboy got a better opportunity and left. A good friend in the Cal Poly administration and I had been talking, so we worked out a deal for a three-year lease. We are now on the five-year extension of that lease, and I am very satisfied, and I hope they are also. I am a graduate of Cal Poly, and one of the phases I liked best was the opportunity for "hands-on" experience. Although the 178 mile distance is an obstacle, the Swanton Pacific Ranch offers a real opportunity for those who want or need the experience. It is also good for class demonstrations.

My first piece of land in this ranch [was] 412 acres of second-growth forest, which I bought in 1943. This past summer we logged about 65 acres of it very selectively. The interest of forestry students and faculty has been inspiring. This is almost the closest commercial forest to San Luis Obispo.

A Santa Clara native, Smith was born April 6, 1921 in San Jose, California. He grew up on his father's ranch at Vasona Junction (now in Los Gatos), purchased in 1911.

The whistles of the Mayfield branch steam locomotives that joined the Southern Pacific line to Santa Cruz at Vasona told him when to get up, when to go to school, when to go to bed; and thus his lifelong interest in railroading began. ${ }^{137}$ His father, as part of summer vacations from Los Gatos, introduced Smith and his brothers to the Little Creek area during camping trips. Smith's first visit to the property occurred when he was 2.5 years old. ${ }^{138} \mathrm{He}$ continued to visit the area at Swanton Pacific Ranch when he attended Camp Totocano (a.k.a. Camp Swanton) as part of the Boy Scouts of America, Scout Troop \#39 (later \#539), with Troop Master Kenny Robinson. ${ }^{139}$ Smith joined the Boy Scouts in 1933, going on to earn the highest scout award, the Golden Eagle [Eagle Scout]. Later in life he served on various Boy Scouts of America boards and received the Silver Beaver, the council-level distinguished service award of the organization. ${ }^{140}$

\footnotetext{
${ }^{137}$ Willys Peck, "Albert B. Smith, Railroad Buff, Teacher, Head of Orchard Supply," San Jose Mercury News (San Jose, CA), Dec. 22, 1993; Peggy Conaway Bergtold, "Los Gatos History Photo: Holiday Wishes from Al Smith," San Jose Mercury News (San Jose, CA), 2010.

${ }_{138}^{138}$ A Smith, interview by unknown, History of Swanton, July 1990.

${ }^{139}$ Al Pregliaco, Smith's childhood neighbor, interview by author, April 12, 2015.

${ }^{140}$ Peck, 1993, 5B; The following information and more is available from Mardi Bennett, Scouting in the Santa Clara Valley: The Seventy Year Adventure 1920-1990: The History of the Santa Clara County Council Boy Scouts of America (San Jose, CA: Santa Clara County Council Boy Scouts of America, 1990):
} 


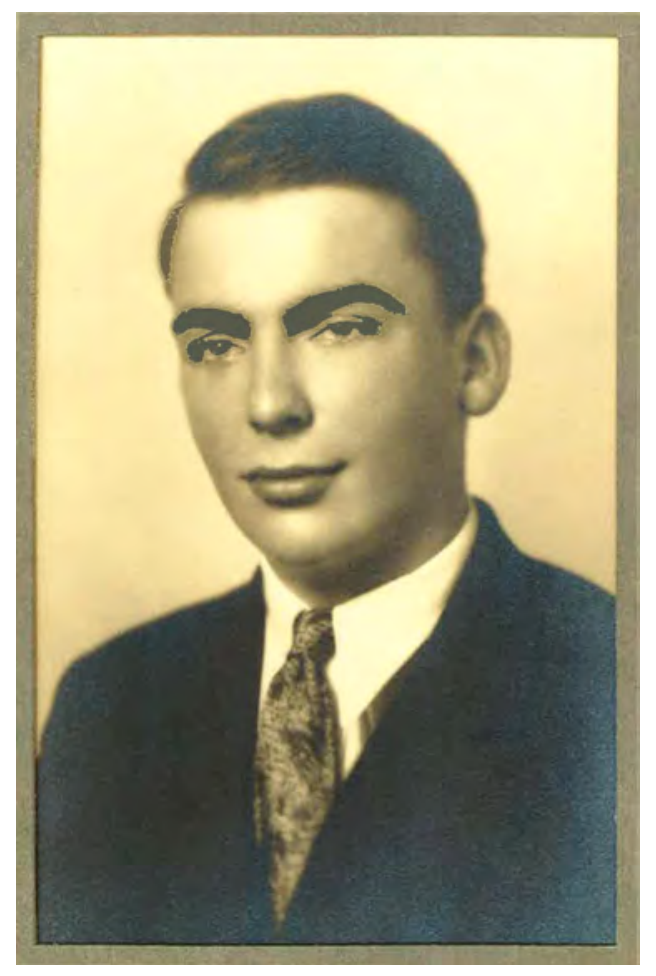

Figure 24: Al Smith Portrait, 1938. Courtesy Cal Poly Corporation, Swanton Pacific Railroad Society Collection.

Smith served as a Trustee of the Foundation and later as the President of the Boy Scout Memorial Foundation Members (1984 to n/a - until after the book was published sometime), xv, 84, 174; "generously provided photographs for the history," ix; The book "begins with the earliest known Scouting activity in Santa Clara Valley...[through] seventy years," xiii; Outdoor activities included leasing "Cam Property" (i.e. Camp Swanton) from the University of California Berkeley for $\$ 32000$, 8; photo shared "Council Trip to Death Valley, 1940, 12; Story from Al Smith, Scout 1934-38: "When we camped here (Camp Swanton) we hiked to a lot of places. There were troop hikes, study hikes, overnight hikes, hikes to Indian burial grounds, the fish hatchery, the deserted village, the dam, Water Snake Lake, and to the ocean. And another thing, about the Indian burial grounds, at Año Nuevo Island where the elephant seal are, the Indian calendar didn't have the same things as our calendar with lots of months with "R's in it. Now, if you have a month with no "R" in it you don't eat shellfish. But the Indians ate shellfish the year around. Every now and then a Red Tide would get them and they (the Indians) would be buried out there, just covered with sand, Año Nuevo is a State Park today. It is an island and we used to go down the other side and walk along the beach," 13. The author of this manuscript notes that this might be something to follow-up on, particularly because it is unclear what Smith means by "calendar."; "To earn the Eagle Scout rank, the highest advancement rank in Scouting, a Boy Scout must fulfill requirements in the areas of leadership, service, and outdoor skills." "The Silver Beaver Award is the council-level distinguished service award of the Boy Scouts of America. Recipients of this award are registered adult leaders who have made an impact on the lives of youth through service given to the council. The Silver Beaver is an award given to those who implement the Scouting program and perform community service through hard work, self sacrifice, dedication, and many years of service."

http://www.scouting.org/scoutsource/BoyScouts/Adults/Awards.aspx 


\section{Education}

Smith graduated from Campbell High School, where his grandfather, J. Fred Smith, was the first principal (see Figure 24: Al Smith Portrait, 1938). ${ }^{141}$ In the 1940s, after attending San Jose State University for a year, Smith transferred to Cal Poly (see Figure 25: Al Smith's Cal Poly Student Identification Card). The opportunity to work on the Southern Pacific Railroad was instrumental in bringing him to study at Cal Poly because the station and the small yard, with the engine terminal, were located south of campus in the town of San Luis Obispo, and the main line ran through the middle of campus. ${ }^{142}$ Smith worked for the Southern Pacific Railroad, in operation on Cuesta Grade. ${ }^{143}$ His love of trains led him early to an assignment (i.e. job) on the railroad as a callboy, waking passengers in the night for their trains. He subsequently became a brakeman, during which time he was injured.

While working on the Southern Pacific Railroad, he lost part of a leg. ${ }^{144}$ Pre-dawn on a morning in February 1943, Smith was walking along the tops of the railroad cars near Pismo Beach when he fell onto the tracks. ${ }^{145}$ The freight train on which he was the

\footnotetext{
${ }^{141}$ Peck, 1993, 5B.

${ }_{142}$ Randy Jones, email to author, August 13, 2015.

${ }^{143}$ Walter E. Rice and Karl Hovanitz, The Saga of the Overfair Railway Pacifics: From Panama to Poly (San Luis Obispo, CA: Silverado Publishing, 1999), 15.

${ }^{144}$ Rice and Hovanitz, 1999, 23, stated that while working in the San Luis Obispo yard Smith lost part of a leg when a blast of steam knocked him off the top of a moving train. This account does not match with the account Smith related to Randy Jones. Randy Jones, email to author, August 13, 2015.

145 "To check the oil or water levels in the tender, Al would have made his way back along the boiler, walking on the running boards while holding onto the handrail above, until he could step down onto the deck between the loco and the tender. He would then reach across the gap to a grab iron (like a steel ladder rung) on the tender itself, and step over, putting his foot on a lower grab iron, and then climb up to the top of the tender. The grab irons were riveted to the tender tank to form a ladder. Somewhere in this process, something gave way and Al went down." Randy Jones, email to author, August 13, 2015.
} 
head brakeman severed his left leg below the knee, and he used his belt as a tourniquet to stop the blood flow so he did not bleed to death. ${ }^{146}$

"Smith was head end brakeman riding the cab of a cab forward locomotive. This distinctive Southern Pacific design put crewman in the very front of the engine, with the smoke stack to the back, and the tender following. ${ }^{147}$ The crew was thus remote from the tender. Smith was sent back to check the fuel or water level in the tender, and when he put his weight on a rusted step (grab iron) it gave way and he went down. It was the tender wheels that severed his leg. He kept a picture on display of the particular locomotive, and would say 'that's the engine that ran over me.' Even though in elaboration he would explain it was actually the tender." 148

He received $\$ 15,000$ in compensation from the railroad. He used $\$ 5,000$ to buy the old Santa Clara Swanton Boy Scout camp, put $\$ 5,000$ in the bank, and invested $\$ 5,000$ into stocks. ${ }^{149}$ Smith used this settlement to fund his education. ${ }^{150}$ In a strange twist of fate "it was to be his last run, as he had [already] enlisted (or was enlisting for the service)... he was eager to join his buddies in service to his country."151

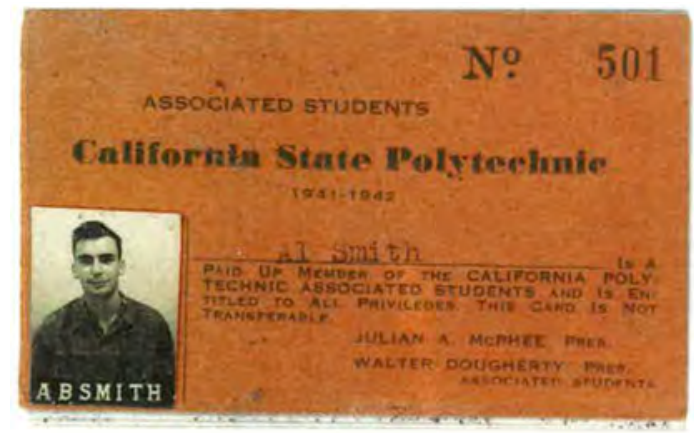

Figure 25: Al Smith's Cal Poly Student Identification Card. Courtesy of Cal Poly Corporation, Swanton Pacific Railroad Society Collection.

${ }^{146}$ Peck, 1993. 5B; Bergtold, 2010. Smith credits his membership in Los Gatos Boy Scout Troop 39 for his first aid knowledge.

${ }^{147}$ A locomotive tender is defined by Merriam-Webster Online Dictionary as "a car attached to a steam locomotive for carrying a supply of fuel and water."

${ }^{148}$ Randy Jones, email to author, August 13, 2015.

${ }^{149}$ Cal Poly College of Agriculture, 5; Rice and Hovanitz,15; Peck, 1993, 5B; Smith, 1990: When the flood of 1940 washed the Scout house away, the land was put up for sale, and Smith, then 24 years old, purchased 412 acres of second-growth forest on Little Creek in 1943 with the settlement he received for his railroad injury. Overtime he continued to assemble parts of the original land grant as property became available.

${ }^{150}$ Randy Jones, interview by author, June 7, 2015.

${ }^{151}$ Peck, 1993, 5B states that in a strange twist of fate Smith was scheduled to be drafted into the Army the day after his accident. This account does not match with the account related by Randy Jones. Randy Jones, email to author, August 13, 2015. 
Smith's connection with San Luis Obispo and Cal Poly were deep starting with his work at the railroad and his schooling. His strong connection to the area was manifested in a variety of ways and ultimately reconnected him to Cal Poly as a donor. While attending Cal Poly, Smith served as student body president. ${ }^{152}$ He applied the agricultural knowledge he learned on his family's orchard and an interest in teaching was added to his educational pursuits. In 1944, Smith earned a BS in Crops Science with a secondary teaching credential from Cal Poly. ${ }^{153}$ His May 1944 senior project was titled "Permanent Cover Crops in California Orchards" with advisors Weir Getter, Eugene A. Eagan, and Paul Dougherty. ${ }^{154}$ Cal Poly instituted a master's degree in education in 1949 and subsequently Smith earned a Master's in Education in $1956 .{ }^{155}$ Smith worked as a high school agriculture teacher and counselor for 17 years (one year in Manteca and the remainder at Campbell High School). ${ }^{156}$ During this time he had been purchasing stock in Orchard Supply, the company that his father, Stanley Smith, helped establish as a farmer's cooperative in $1931 .^{157}$

\footnotetext{
${ }^{152}$ Peck, 1993, 5B.

${ }^{153}$ Peck, 1993, 5B; Rice and Hovanitz, 1999, 15; Bergtold, 2010.

${ }^{154}$ A copy of the senior project available on microfiche in the Robert E. Kennedy Library at Cal Poly.

${ }^{155}$ Cal Poly Foundation, 2001; Rice and Hovanitz, 1999, 15; It is unclear if there is an image of Smith in the El Rodeo, the Cal Poly yearbook, because (1) publication was suspended between 1943-1945 (World War II) and (2) searching the online copies of the yearbooks produced results that included content related to individuals that were not Albert E. Smith. It would be a great project to have someone track down all the El Rodeo entries of Al Smith during his tenure at Cal Poly. The yearbooks are all available online with full-text searching at: http://digitalcommons.calpoly.edu/elrodeo/

${ }^{156}$ Peck, 1993, 5B; Rice and Hovanitz, 1999, 15; Bergtold, 2010; Al Smith was Randy Jones's sister's counselor. She graduated in 1961. Randy Jones email to author, August 13, 2015.

${ }^{157}$ Peck, 1993, 5B.
} 


\section{Orchard Supply Hardware}

Orchard Supply was founded as a cooperative in 1931 by 30 farmers; it was led and managed by Stanley Smith, Al Smith's father. ${ }^{158}$ The cooperative moved from a small operation during the Interwar Period and the first decade after World War II to a nonmember retail operation in the 1950 s; the organization grew from 30 farmers to 2,000 farmers. With the electronics industry booming in the 1950s farmers began to sell their orchards to residential developers, and the Orchard Supply Farmers Co-op became a for profit corporation named Orchard Supply Hardware to support the new community. The co-op relocated a number of times, and in 1946 the organization built a new store at 720 West Carlos Street, San Jose, California. This location included a Southern Pacific Railroad served warehouse. ${ }^{159}$ In 1962, AI Smith became president of Orchard Supply Hardware (OSH) (see Figure 26: Al Smith, Orchard Supply Hardware Portrait, circa 1970 and Figure 27: Al Smith on a Southern Pacific Caboose). ${ }^{160}$

\footnotetext{
${ }^{158}$ Please refer to Appendix C: Orchard Supply Hardware's Inception for additional historical information. ${ }^{159}$ Franklin Maggi, Historic Report: Orchard Supply Hardware (San Jose, CA: Archives and Architecture, LLC, 2012), 6.

${ }^{160}$ An amusing anecdote (with many different variations) that is often shared by people who knew Smith that demonstrates his down to earth manner is that Smith would often go to stores and work at the cash register to observe customers' experiences (others say he did it just "because"). He looked like anyone else, did not identify himself as the president of the company, and some say he often wore overalls. One day while he was working at the register an "undercover company shopper" went through Smith's line, and did not recognize his boss. The rumor was that when the shopper reported his findings later they were less than favorable. "Smith also shared with [Randy Jones] his philosophy regarding checkout lines. An approximate quote, 'Always keep enough check stands open to handle the customers. Don't make them wait very long. They want to give you their money. Don't make them wait to do it. They might decide they don't need what they picked out after all, or decide not to come back'." Randy Jones email to author, August 13, 2015.
} 


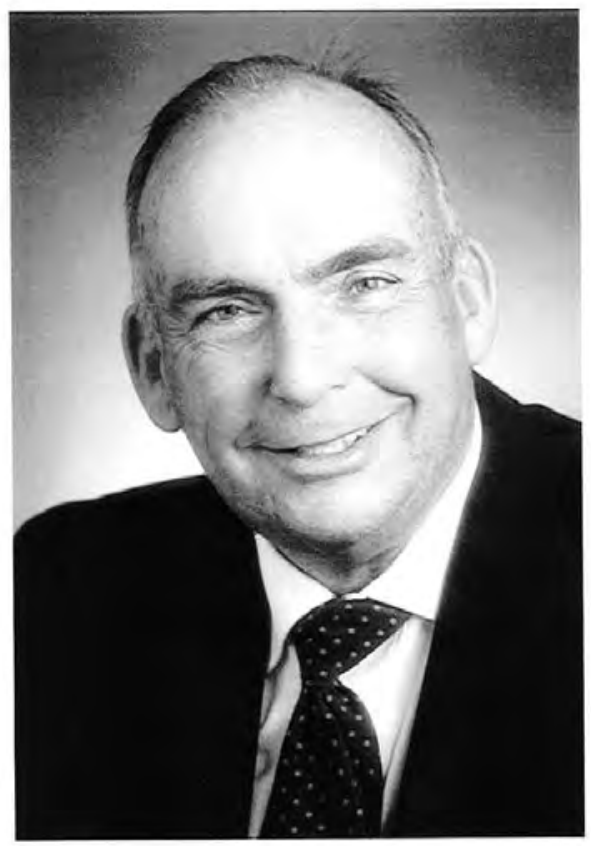

Figure 26: Al Smith, Orchard Supply Hardware Portrait, circa 1970. Courtesy of Cal Poly Corporation, Swanton Pacific Railroad Society Collection.

Smith pioneered a business strategy for the large scale, self-service hardware company. ${ }^{161}$ Under his direction, Orchard Supply Hardware grew from one store off San Carlos Street, with branch stores being established throughout the Santa Clara county and nearby counties: in 1965 on the east side of San Jose at 3000 Alum Rock Ave.; in 1968 on Branham Lane; in 1972 in Sunnyvale; in 1973 in Capitola; in 1975 in Gilroy; and in Livermore in $1976 .{ }^{162}$ Smith credited his hardware manager, Kenneth J. Lewis, as the architect of the expansion. ${ }^{163}$

\footnotetext{
${ }^{161}$ Rice and Hovanitz, 1999, 15.

${ }^{162}$ Franklin Maggi, Historic Report: Orchard Supply Hardware (San Jose, CA: Archives and Architecture, LLC, 2012), 6.

${ }^{163}$ Peck, 1993, 5B.
} 
Later Smith served on the Los Gatos Town Council from 1974 to 1977, and in 1977 he was elected Mayor of Los Gatos. ${ }^{164}$ After the mayoral election, Smith turned over company control to his brother, Loren Smith. ${ }^{165}$ Loren Smith established additional locations in both Modesto and Fremont in 1979 and then in San Lorenzo, Dublin, and Vallejo in $1980 .{ }^{166}$ When Orchard Supply was sold in 1979 to W.R. Grace \& Co., Al Smith who owned a controlling interest, retired. ${ }^{167}$

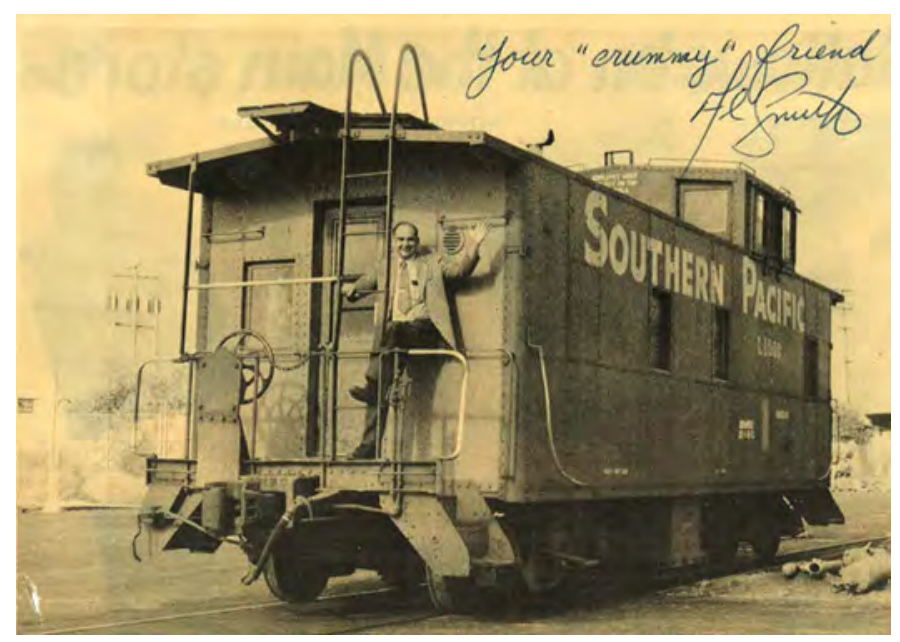

Figure 27: Al Smith on a Southern Pacific Caboose. Smith can be seen here on a Southern Pacific Caboose, which served as his office at Orchard Supply Hardware, 720 West San Carlos Street, San Jose, CA. Courtesy Cal Poly Corporation, Swanton Pacific Railroad Society Collection.

\section{Swanton Pacific Ranch}

In 1978, Smith settled in Swanton, purchasing the last 270-acre parcel of his ranch in 1986 (see Figure 28: Al Smith, Strawberry Shack, Swanton Pacific Ranch, circa

\footnotetext{
${ }^{164}$ Willys Peck, "Albert B. Smith, Railroad Buff, Teacher, Head of Orchard Supply," San Jose Mercury News (San Jose, CA), Dec. 22, 1993; Maggi, 2012, 6; Bergtold, 2010.

165 Maggi, 2012, 6.

166 Ibid.

167 Jack Viets, "Cal Poly Given a Ranch - If It Keeps Developers Away," The San Francisco Chronicle (San Francisco, CA), Feb. 19, 1987; Peck, 1993, 5B.
} 
1980). ${ }^{168}$ The Swanton Pacific Ranch got its lazy SP brand, $\mathcal{P}$, because many of

Smith's Southern Pacific Railroad tools were stamped S.P. ${ }^{169}$

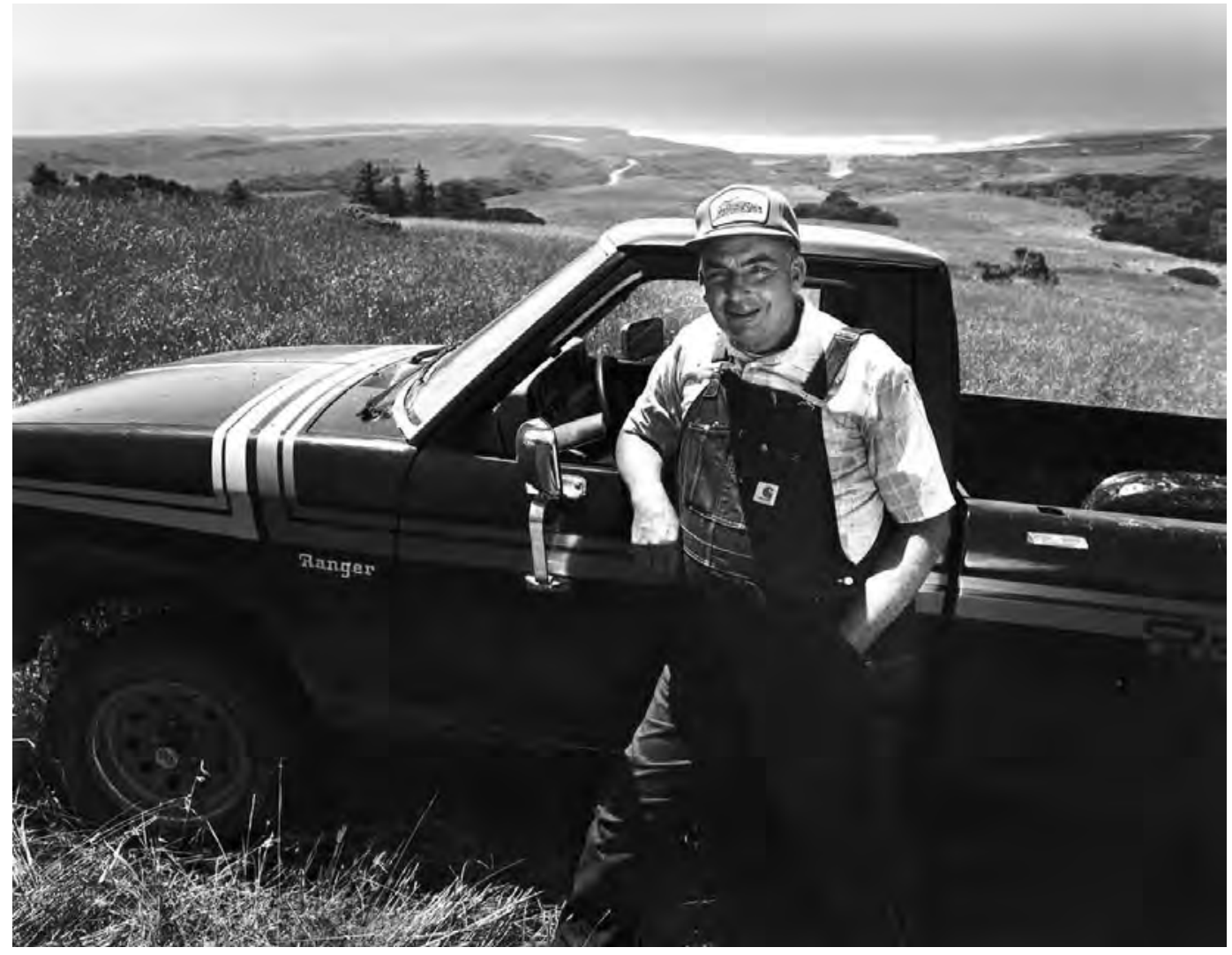

Figure 28: Al Smith, Strawberry Shack, Swanton Pacific Ranch, circa 1980. Courtesy of Cal Poly Corporation, Swanton Pacific Railroad Society Collection.

\footnotetext{
168 Viets, $1987,40$.

${ }^{169}$ Rice and Hovanitz, 1999: When Smith bought from Bob Maxfield the \#1912 and \#1913, in 1979, he moved them to the Swanton Ranch, and the "Swanton Pacific Railroad" (a.k.a. the "Lazy Espee or SP") was born; The Virtual Museum of the City of San Francisco site,

http://www.sfmuseum.net/hist9/overfair.html, also provides a great history of the railroad; Smith, 1990: "Swanton Pacific Ranch. It got its name because, somehow, many of my tools were stamped S.P. The brand I selected was the lazy SP. It is by the Pacific, and it is in Swanton." At this time the author has not determined if the lazy SP has been trademarked by Cal Poly. However, in August 2015 the author learned from Swanton Pacific Ranch Livestock Manager Gordon Claassen and Susan Claassen that the Swanton Pacific Ranch livestock brand had been registered: California Department of Food and Agriculture, Bureau of Livestock Identification, 2010 Brand Book, page 332, available online at https://www.cdfa.ca.gov/AHFSS/Livestock_ID/pdfs/2010_Brand_Book/S.pdf. The brand itself looks like:

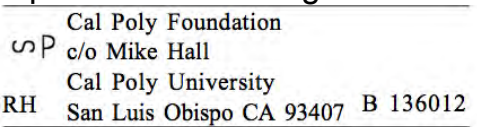




\section{Swanton Pacific Railroad}

Al Smith's leadership of Orchard Supply resulted in profits, expansion, and later significant monies from the sale of the business; this legacy went on to provide for the Overfair Railway Pacifics future [a.k.a Swanton Pacific Railroad]. ${ }^{170}$ (See Appendix D: Swanton Pacific Ranch Railroad Timeline for more information on the history of the railroad.) The Ranch is home to a one-third scale small gauge steam railroad that follows 1.5 miles of track near Scott Creek. This railroad was part of the Panama-Pacific Exposition hosted in San Francisco in 1915 to demonstrate the recovery from the 1906 earthquake. ${ }^{171}$ The railroad is maintained and operated by the Swanton Pacific Railroad Society.

Smith believed that his railroad was to be available for the enjoyment of himself, his friends, and his neighbors, and one way he shared his love of trains was with an annual New Year's Eve celebration. The $20^{\text {th }}$ New Year's Eve party and [rail] run was held on December 31, 1988. Martha Neilsen (n.d.) said the first celebration consisted of an informal dinner with neighbors and friends bringing six different kinds of stew and Ken McCrary's hot cider (still served today), "the only liquid refreshment Al would allow" while

\footnotetext{
${ }^{170}$ Rice and Hovanitz, 1999, 15.

171 There is an interesting connection of Fred Swanton with the Swanton Pacific Railroad. In 1915, San Francisco hosted the world's fair, and the Panama-Pacific International Exposition (PPIE) was designed to celebrate the opening of the Panama Canal. This was San Francisco's opportunity to prove that the city had fully recovered from the earthquake. Swanton was the president of the Combined Amusement Company that was contracted to build exhibits for the amusement park and concession area, The Zone, at Fort Mason, for the PPIE. The Zone also introduced visitors to the idea of national parks including replicas of the Grand Canyon and Yellowstone Park. The PPIE was also the place where the railroad that eventually became known as the Swanton Pacific Railroad was unveiled. Groff, 1915, 140; National Park Service, U.S. Department of the Interior, n.d.,15, http://www.nps.gov/goga/planyourvisit/upload/sg-foma.pdf. Also refer to Figure 29: Al Smith's Parents at The Panama-California Exposition for another interesting connection.
} 
the equipment was running. ${ }^{172}$ Future attendees learned about the event by word of mouth. ${ }^{173}$

172 "All railroads have in their General Code of Operating Rules a Rule G. This prohibits alcohol or other intoxicants on the property. Smith always spoke fondly of the Swanton Pacific's 'modified Rule G,' which mandated strict sobriety while operating equipment. But if you were working hard laying track or afterward and the rolling stock was 'put to bed,' beer was the order of the day." Randy Jones email to author, August 13, 2015.

${ }^{173}$ Swanton Pacific Railroad Society Newsletter 68, Dec. 1998, http://content-calpolyedu.s3.amazonaws.com/sprr/1/documents/98_12.pdf. 


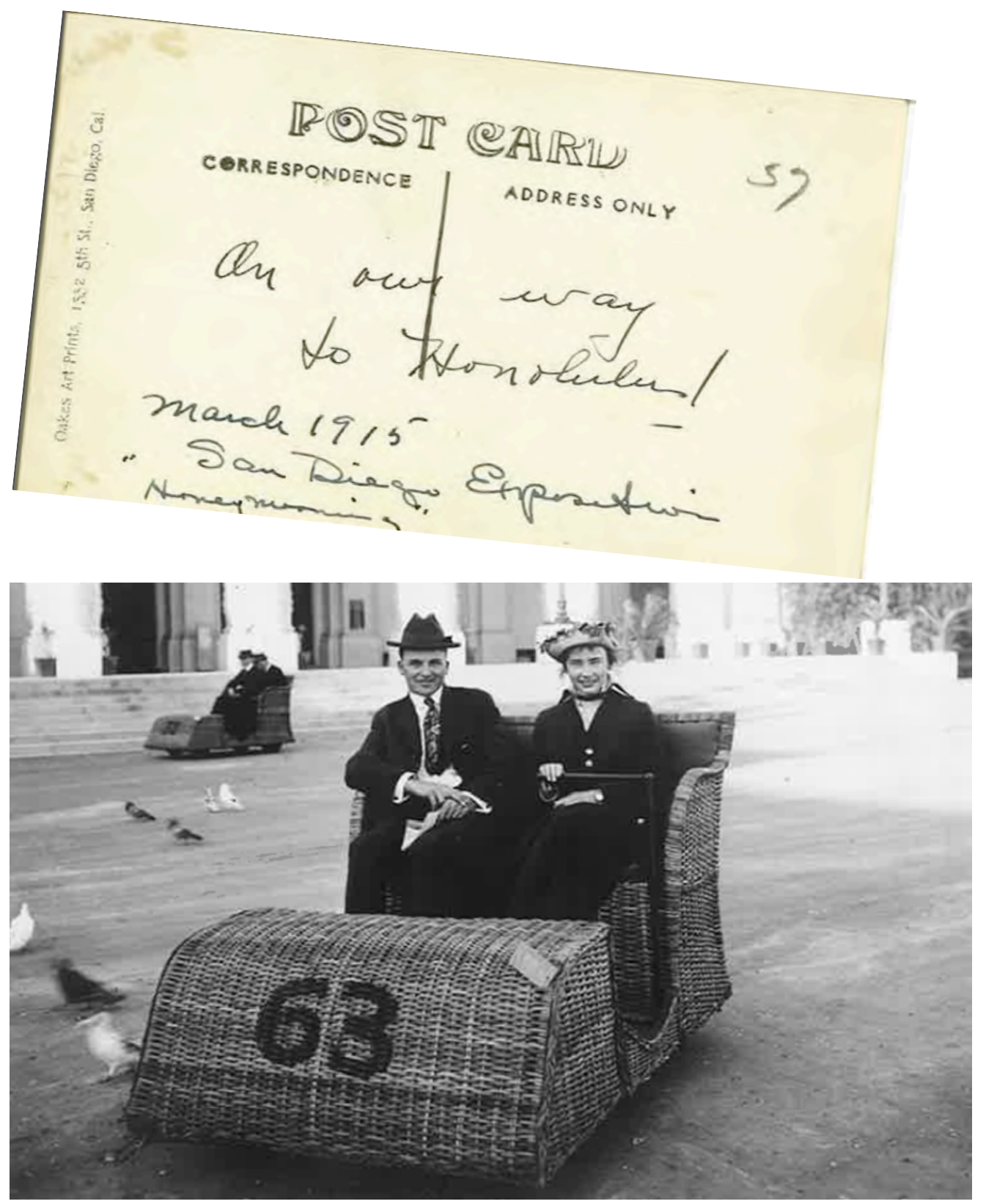

Figure 29: Al Smith's Parents at The Panama-California Exposition. Here is a postcard of Al Smith's parents at The Panama-California Exposition (PCE), an exposition held in San Diego, California, between 1915-1916. This exposition was held in competitive response to San Francisco's 1915 Panama-Pacific International Exposition (PPIE). It is an interesting connection that Smith's parents attended the PCE and Smith acquired a PPIE attraction, Overfair Railway, later in life. Courtesy of Cal Poly Corporation, Swanton Pacific Railroad Society Collection. 


\section{Cal Poly}

"I want to keep the Ranch as open space (in respect non-developed), a working ranch. That's what it is," said Albert B. Smith. ${ }^{174}$ In 1986, Smith worked out a three-year lease with the Cal Poly administration for $\$ 100$ per year, then extended for five-years, to support a hands-on educational program for students, a program that he himself had experienced during his time as a student at the university. ${ }^{175}$ Originally much of the cropland was leased, some of the grassland was leased, and Cal Poly operated the rest of the Ranch, including the timber stands, with the help of Big Creek Lumber Company. The Ranch was used by students for a variety of educational purposes, but student accommodation was limited for the first few years due to lack of housing and faculty on site. Initially Smith gave $\$ 1$ million to establish a quasi-endowment for Swanton Pacific Ranch's operating capital, and then in 1991 he donated an additional \$1 million of W.R. Grace stock to be used expressly for instructional enhancement and to fund a resident faculty position for three years, during which time a project director was appointed and a full-time ranch supervisor was stationed at Swanton Pacific Ranch. ${ }^{176}$ In 1991, the internship program began to include part- and full-time interns and the distance learning equipment was purchased and installed in the Red House. The Bunk House and Casa Verde were renovated to accommodate up to 14 interns.

\footnotetext{
${ }^{174}$ Interview with Viets, 1987, 40.

175 Viets, 1987, 40; This paragraph contains quotes and paraphrases of content within the Cal Poly College of Agriculture, 1; See Appendix F: School Of Agriculture Work Day 1991 Agenda

${ }_{176}$ Cal Poly, 2011, 35; From Lou Haughney's papers, unknown Author, September 1997, the information is from a very distorted copy of what looks like it came from an old Cal Poly, College of Agriculture Website;

Kevin Piper and Brenda Smith served together as ranch managers approximately starting in 1991. Subsequently Walter (Wally) Mark was the first official ranch director, serving from 1996 to 2004. Brian Dietterick has been director since 2004.
} 
In 1993, Smith became the first recipient of the university's highest honor, the President's Medal of Excellence. ${ }^{177}$ Shortly after, Smith passed away of cancer. ${ }^{178}$ Smith never married. ${ }^{179}$ He thus willed the bulk of his assets (i.e. 3,2000-acre Swanton Pacific Ranch, the approximately 600-acre Valencia Creek property in Santa Cruz County, and a substantial endowment valued at $\$ 22$ million) to the education of students. ${ }^{180}$ The living trust conditions state that Swanton Pacific Ranch: "[...] be maintained as a working ranch for instructional purposes and that it not be sold or transferred to other than another entity exempt from taxes, which will maintain its use exclusively for agricultural, recreational or educational purposes." ${ }^{181}$ After Smith's passing, Al Smith Day, a

\footnotetext{
${ }^{177}$ Cal Poly Communications Department, 1: "Rancher, Cal Poly graduate and university benefactor Al Smith, 72, died of cancer Dec. 18 at his home near Davenport, one week after becoming the first recipient of Cal Poly's President's Medal of Excellence. Smith was formally presented the Medal of Excellence at Fall Commencement Dec. 11 in recognition of his exceptional contributions to Cal Poly and the College of Agriculture. During the last few years, he had made his Swanton Pacific Ranch north of Santa Cruz available for instructional programs and made major donations to the university. He was unable to attend Commencement but watched the ceremony on television through a specially installed satellite link to his home. President Baker went to Smith's Ranch a few days before the ceremony to present the actual medal. President Baker gave the eulogy at a memorial service Dec. 22 in Campbell."

${ }^{178}$ Even in death his commitment to Cal Poly was evident. His obituary said that in memorial "contributions may be made to the California Polytechnic State University Foundation, in care of the University, San Luis Obispo, Calif. 94307." Peck, 1993, 5B.

${ }^{179}$ Staff Writer, "Martha Neilsen Obituary," San Jose Mercury News (San Jose, CA), Jan. 14, 2014, http://www.legacy.com/obituaries/mercurynews/obituary.aspx?pid=169080172: "Martha Jean Neilsen, Al Smith's companion, died on December 3, 2013, in San Jose, CA. She was born in Mt. Cory, OH, on March 7, 1929, daughter of Thomas A. Cook and Susie Pearl Cook. She moved to Santa Clara County from Ohio in 1962. She is survived by six children and eight grandchildren. Martha worked for Orchard Supply Hardware for over 25 years where she was credit manager and was very active in the Swanton Pacific Railroad"; Margaret Taylor, interview by author, April 12, 2015: Margaret and Martha were friends and became connected through the Railroad. Martha would make meals for railroad work weeks and began the garden next to the round house. "Her contributions to the Swanton Pacific Ranch Railroad and Swanton need to be remembered and honored."

${ }^{180}$ Cal Poly Foundation, 2001.

${ }^{181}$ See Appendix G: Swanton Pacific Ranch Internship Information Packet 1998, 1. It is important to mention that the concepts of a working ranch and one for instructional use act in concert with one another.
} 
celebration of his life and legacy, started the next year and continues to this day on the weekend in April closest to his birthday. ${ }^{182}$

Smith's dream of a living laboratory is a reality evident in the continued development of educational opportunities since his passing. The infrastructure to support Cal Poly student, staff, and faculty work on the Ranch continues to improve, allowing for increased utilization of the property.

${ }^{182}$ Cal Poly Swanton-Pacific Railroad Society invitation, March 18 1994, http://content-calpolyedu.s3.amazonaws.com/sprr/1/documents/94_03.pdf. 


\section{CHAPTER 4: THE ARTISTIC AND INTELLECTUAL BIOGRAPHY OF SWANTON (1950-PRESENT)}

Swanton has inspired creativity and supported intellectual pursuits, scientific knowledge, educational opportunities, and artistic expression. Although less well known, Swanton-like Big Sur and the Marin Coast-has supported an artistic and intellectual tradition. There are innumerous natural lands and places that have their own rich artistic and intellectual biographies. The complexity of the landscape's ecosystem mirrors the complex relationships between people. The two overlap, providing a fertile physical and ethereal space that is rich and abundant.

Swanton Valley is but one example of a complex relationship between a natural setting, its history, and the people that have maintained the land. The land and how it is changed by people creates a unique set of environmental conditions that influences the intellectual and scholarly culture of the area. As humans modified and maintained the landscape over time, they superimposed their idea of how the land should be used, and created human parameters regarding the possibilities for art and intellectual pursuit on the property. The artistic products are constrained by the culture of the Valley: what individuals value, what they allow people to access, and what support or lack of support is offered. It is important to note that the culture is not static but changes over time.

Below are a few examples of the individuals and academic entities involved in these activities: Robert Sudlow, Big Creek Pottery, William Everson, University of California, Berkeley, Cal Poly, and James West. 


\section{Artistic Biography}

Robert Sudlow (1940s-1990s)

Robert Sudlow (1920-2010) is widely considered the most esteemed artist in his home state of Kansas. ${ }^{183}$ In 1946, he began spending summers in the Swanton Valley, painting the local area. His painting Landscape, Santa Cruz, won the Topeka Junior League purchase prize and his work became part of the Kansas Mulvane Art Museum collection in $1948 .{ }^{184}$ During Sudlow's time in California, he earned an MFA in 1956 from the California College of Arts and Crafts in Oakland and received a number of summer California artist residencies during the next few years. ${ }^{185}$ Sudlow described himself as "transplanted between Kansas and California."186 The Gianone family gave him a "second home" during his summers. He stayed close with the family and their in-laws, the Wests, throughout his time painting in Swanton. ${ }^{187}$ Artists before and after him have found inspiration at the location and support from the residents of the area. ${ }^{188}$

Big Creek Pottery (1960s-1980s)

In 1963, Bruce and Marcia McDougal bought an old school bus in lowa for $\$ 50$ and drove to California. They moved to Santa Barbara where they imported, made, and

\footnotetext{
${ }^{183}$ Robert Sudlow, Spiritual Journeys: The Art of Robert Sudlow (Kansas City, MO: Exhibits USA, 2002) 21. 184 Ibid.

185 Ibid., 67.

${ }^{186}$ Ibid., 33.

187 Ibid., 6, 21.

${ }^{188}$ A few of the images created in Swanton and Davenport can be found in Sudlow (2002): Landscape, Santa Cruz, 1948, page 21; Santa Cruz Honeysuckle, 1981, page 31; Santa Cruz, 1981, page 32; and Foggy Headlands, Gianone Ranch, 1982-1989, page 33.
} 
sold strung beads out of a little shop from 1964-1967. ${ }^{189}$ A fellow potter, Al Johnsen, introduced them to the Davenport area where they discovered an abandoned dairy ranch on Swanton Road. They thought the abandoned ranch would be perfect for a pottery school, but it belonged to Big Creek Lumber. ${ }^{190}$ Nevertheless, they had discovered Swanton, a place that provided quiet, beauty, and a benefactor to help bring their dream of starting a pottery school to fruition. The McDougals say their school, housed in a restored cheese house, two main houses, and a 150-foot barn, would never have come into existence without the know-how, investment, and generosity of the McCrary family, owners of Big Creek Lumber. ${ }^{191}$

The Big Creek Pottery School was the first residential learning community in the Western United States, running from 1968-1984, hosting over 1,000 students from across the country and world, with students living and working together for nine-week summer sessions. ${ }^{192}$ The attraction of the residential nature of the community drew students as did its setting in a rural area on the rugged California coast (likened to Big Sur). Fall and spring sessions were added as the school's popularity grew. There were classes five days a week, with the studio open seven days a week, twenty-four hours a day. ${ }^{193}$

\footnotetext{
${ }^{189}$ Tina Baine, "Through the Potter's Wheel: Big Creek Pottery Looks Back." Santa Cruz Sentinel, Mar. 26, 2011. http://www.santacruzsentinel.com/general-news/20110326/through-the-potters-wheel-big-creekpottery-looks-back.

${ }^{190}$ Baine, 2011.

191 Baine, 2011; Karen Thuesen Massaro, "Big Creek Pottery," Ceramics Monthly Apr, (2011): 48-52; Lisa Jensen, "Incandescent Moments," Santa Cruz Good Times (Santa Cruz, CA), Mar. 25, 2011.

http://www.gtweekly.com/index.php/santa-cruz-arts-entertainment-lifestyles/santa-cruz-arts-entertainment/2318-incandescent-moments.html.

192 Baine, 2011; Massaro, 2011a; McDougal, n.d.

193 Jensen, 2011.
} 
Breakfast began at $7 \mathrm{am}$, morning class was held at $9 \mathrm{am}$, lunch was at $12 \mathrm{pm}$ and was followed by an afternoon class, dinner, and a relaxing evening. ${ }^{194}$

The McDougals nurtured students as they found their own style of pottery, offered the experience of living in a community, and provided a venue for master craftspersons from around the world to share their work. ${ }^{195}$ They convinced English potter Michael Cardew to visit America at 75 years of age, who later went on to write a letter to the McDougals saying that his three weeks at Swanton had been one of the most important experiences of his life. ${ }^{196}$ The students, as well as those who came to share their knowledge, stated that their time at Big Creek Pottery was a life-changing experience. ${ }^{197}$ Bruce McDougal also designed a do-it-yourself (DIY) pottery wheel, Kick Wheel Plan, in $1974 .{ }^{198}$ In 1977 , they had the ambitious idea of starting a production pottery studio and retail space for their previous students in the space where the former Davenport Cash Store had been. ${ }^{199}$ The McDougals closed the school in 1982 and transformed the studio into the New Davenport Cash Store and Bed and Breakfast. ${ }^{200}$ They ran the B\&B until 2006.

\footnotetext{
${ }^{194}$ Massaro, 2011a.

${ }^{195}$ Baine, 2011; Jensen, 2011.

196 Jensen, 2011; Locating the letter or others like it would provide valuable insights about the School, people's ideas of community, what effects famous artists had on the students, and what the artists learned from the students. At this time the author has not been able to locate documentation of this sort. There may be interviews on the SCMAH DVD from the Big Creek Pottery exhibit: Massaro, Karen Thuesen Big Creek Pottery, a Social History of a Visual Idea, 1967-1983: An Oral History Interview with Bruce and Marcia McDougal. Santa Cruz, CA: The Museum of Art and History McPherson Center, 2011.

197 Baine, 2011; Jensen, 2011.

198 Plans for the Kick Wheel Plan are available online at: http://ceramicartsdaily.org/wpcontent/uploads/2011/03/mcdougalkickwheelplan8x11.pdf

${ }^{199}$ Ann Parker, "Smart Money: The Century-old Davenport Cash Store has a Colorful History and a Menu to Match," Metro Santa Cruz (Santa Cruz, CA), Feb. 19-26, 2003. http://www.metroactive.com/papers/cruz/02.19.03/dining-0308.html. 200 Jensen, 2011.
} 
William Everson (1970s-1990s)

William "Bill" Everson (September 10, 1912 - June 3, 1994) passed away at the age of 81 in his rustic Swanton cabin, "Kingfisher Flat."201 Both of Everson's parents were printers, and later as a conscientious objector during World War II, he learned the art of handset printing in the work camps. ${ }^{202}$ His first marriage did not survive the war and when his second marriage failed he entered the Dominican Order and took the name, Brother Antoninus; Everson was nicknamed "The Beat Friar" in reference to the Beat Movement/Generation of which he was a part. ${ }^{203}$ Everson renounced his Dominican calling in 1969 when he fell in love with his third wife. ${ }^{204}$ Two years later he took a position at the University of California, Santa Cruz (UCSC), founding the University's Lime Kiln Fine Art Press, and he served as poet in residence during the 1970 s and early 1980 s. $^{205}$

Everson found a home at Swanton, where he easily fit into the small but vibrant art community that was already established. He shared his poetry and fine printing in the physical works he created, but also he shared his artistic knowledge by contributing to the teaching of students at UCSC. Everson published over fifty volumes of poetry and received honors including a Guggenheim Fellowship, a Pulitzer nomination, the 1991

\footnotetext{
${ }^{201}$ Geoffrey Dunn, "The Death of a Poet," Santa Cruz County History - People, 1996. http://www.santacruzpl.org/history/articles/224/; Ken Rumsey, "William Everson." http://www.rooknet.net/beatpage/writers/everson.html.

${ }^{202}$ Dunn, 1996; Rumsey, n.d.

203 Ibid.

204 Ibid.

205 Ibid.
} 
Artist of the Year by the Santa Cruz County Arts Commission, a National Endowment for the Arts Grant, and the PEN Center USA West Body of Work Award. ${ }^{206}$

Intellectual Biography

University of California, Berkeley

University use of Swanton has included the University of California, Berkley, University of California, Santa Cruz, and Cal Poly. The first academic institution to conduct classes in Davenport and Swanton was the University of California, Berkeley. The College of Engineering conducted a Summer School session of Surveying in May and June between 1904 and 1924 in Davenport and Swanton. ${ }^{207}$ Students came by train to lay out roads and survey the land. ${ }^{208}$ These engineering students were responsible for the construction of the Red House. ${ }^{209}$ (See Appendix H: The Cal Barn: 100 Years of Universities in the Coastal Region of Northern Santa Cruz County, for more information and primary source excerpts.)

From 1908 to 1922, Professor Charles Derleth, Jr., Head of the Civil Engineering Department, tried to convince the University President and Regents to purchase the leased campsite and the surrounding 2,500 acres for the University of California system. Fortunately for Cal Poly, the University of California system did not buy the land, and later

\footnotetext{
${ }^{206}$ The Poetry Foundation, n.d., has an extremely long bibliography and further reading on and by William Everson available online at: http://www.poetryfoundation.org/bio/william-everson; Jay Salter, who lives in Swanton, is highly regarded in writing circles and was friends with Bill Everson, Jim Houston and many other literary notables. Studying the history of his work may be another avenue for research.

${ }^{207}$ Bob Parkinson, Swanton Pacific Railroad Society, n.d.

${ }^{208}$ Smith, 1990: "For several years the University of California (Berkeley), College of Engineering, ran summer school here. Students would come by train and lay out roads and survey land for a summer semester. There are many stories told about cold water, poison oak and snakes, although there are only a few graduates left. (The building by the Red House was built by the engineering students.)"

${ }^{209}$ Smith, 1990.
} 
Smith did. ${ }^{210}$ With Smith's purchase of the land and subsequent bequest of the land to Cal Poly, Derleth's dream to have the land used as an educational site became a reality.

\section{Cal Poly Scholarship and Learn by Doing}

Cal Poly has supported both artistic and scientific endeavors ever since it has leased and owned Swanton Pacific Ranch. The land provides a place/canvas for the convergence of science and art through the Learn by Doing pedagogy of Cal Poly. ${ }^{211}$ Many projects have been completed at Swanton, and they are not co-located, which makes the work that the students, staff, and faculty accomplish and continue to perform more difficult to explore. It is important that these records are made more easily accessible. $^{212}$

Cal Poly, government agencies, and other universities (e.g. University of California, Santa Cruz, and University of California, Berkeley), faculty, and researchers have published an unknown number of works about Swanton. Uncovering content for this thesis resulted in the indexing of more than 120 Cal Poly class projects, senior projects, and masters theses (See Appendix I: Cal Poly and Swanton Research Projects and Reports Index.) $)^{213}$ There are numerous other projects to discover and index. ${ }^{214}$ Those

\footnotetext{
${ }^{210}$ Lou Haughney, Swanton Pacific Railroad Society Historian, personal papers, Box 2.

${ }^{211}$ An interesting project would be to study the pedagogical implementation of Learn by Doing at the Ranch.

${ }^{212}$ There is extensive information including current ranch internships and classes, ranch operations, research, and the Swanton Pacific Railroad Society available online at http://spranch.calpoly.edu/index.Idml; Older descriptions of internships available in Appendix G: Swanton Pacific Ranch Internship Information Packet 1998.

${ }^{213}$ This index is not comprehensive; as well, due to space constraints the table presented in this thesis only lists the first author even when there are multiple authors.

${ }^{214}$ At this time, all Cal Poly theses have to be uploaded to DigitalCommons@CalPoly and any senior projects are submitted to Cal Poly's Robert E. Kennedy Library. The content is full-text searchable. In addition, a "Swanton Pacific Ranch" specific page has been added to DigitalCommons@CalPoly, which is being populated with links to projects conducted at the ranch. This content is available online at:
} 
currently identified in Appendix I span all but one college. ${ }^{215}$ There are classes, senior projects, and masters theses that have included agricultural business models; graphic design of Swanton Pacific Ranch brochures; development of school education tours and trail guides that highlight the Ohlone's medicinal use of plants; development of Boy Scout merit badges; and hydrology, ranching, farming and management plans. ${ }^{216}$ As well, there have been two reports that map, record images, and outline the history of the buildings, both in 1995 and 2004, but there is a need for a more recent review. ${ }^{217}$

A fascinating example of how the ranch management has been modified over the years is seen in the harvesting philosophy and Non-Industrial Timber Management Plans (NTMP). The sustainable harvest is based on a four-year cycle that allows undergraduate students to see the process during their time as students at Cal Poly. ${ }^{218}$

Cal Poly's Learn by Doing activities have also included Shakespeare at Swanton. ${ }^{219}$ Performances by Dr. Steven Marx's English 431 students held February 26-

http://digitalcommons.calpoly.edu/spr_stu/; Examples of materials that need to be tracked down from The Student Use of Swanton Pacific Ranch - 1997-98 College Year complied by Walter (Wally) Marks, include the following: completed senior projects and special problems - Erosion Control for Little Creek Flumes, Silvicultural Prescription for Scotts Creek Stand, Stream Profile for Scotts Creek, Calibration Curves for Little Creek Flumes, Weir Design for Little Creek Flumes, Local Volume Tables for Valencia Creek, and Continuous Forest Inventory of Little Creek; continuing senior projects and special problems - Mapping of Rangeland and Five Year Plan, and Range Management Plans; masters theses - Flora of Swanton Pacific Ranch and Non-Industrial Timber Management Plan for Valencia Creek.

${ }^{215}$ One area significantly lacking in collection is that of reusable data (ex. water quality, GIS) and reusable processed data.

${ }^{216}$ The 2004 General Management Plan, 2011 Swanton Pacific Ranch Management Plan, and NonIndustrial Timber Management Plans (NTMP) Documents are available online at http://spranch.calpoly.edu/forest_management.ldml.

${ }^{217}$ Glenn W. Salo, "A Survey of the Buildings on the Swanton Pacific Ranch," California Polytechnic State University, 1995; Tanner O. Hartman, and Clinton J. Isbell, "Structures of Swanton Pacific Ranch," Class Project FNR 418: Applied GIS, California Polytechnic State University, 2004.

${ }^{218}$ Russ White, conservation with author, June 17, 2015.

${ }^{219}$ Also see Steven Marx, ed., Cal Poly Land: A Field Guide (Santa Maria, CA: Accurate Color Printing, 2002) for images and short descriptions of more art projects at Swanton: installations in natural settings workshop, Art and Design Department, Winter 2000 and 2001, pages 208-209; puppet-making workshop, 
28, 1999 included: A Midsummer Night's Dream, Act 3 Scene 2; King Lear, Act 4 Scene

6; and The Winter's Tale, Act 3 Scene $3 .{ }^{220}$ In addition, the students wrote essays about their experience. ${ }^{221}$ There also is a collection of Swanton Pacific Ranch images shared through the Cal Poly Land website that include: The Textures of Swanton Pacific Ranch Plants and Decaying Human Works; Humans, Plants and Decaying Human Works; Steel and Wood; Stone and Water; Humans, Stone and Water; and Humans and Plants. ${ }^{222}$ The purpose of these images is "to consider the relationships between the different textures found at Swanton Ranch.... Engaging in such an exercise, it is possible for individuals to better understand the place and their own relationship to it."223

Art and Design Department, Spring 2002, 209; Environmental Education - Swanton Pacific Ranch, pages 247-248.

${ }^{220}$ Images are available online at http://cla.calpoly.edu/ smarx/Shakespeare/shakeswanton/shwanton.html; The website provides links to video recordings, but the links do not work; Steven Marx (and the thesis author) has the video footage; however, the files have been corrupted and a computer engineering student could attempt to recover the files so they can be saved for future review.

${ }^{221}$ These essays can be read online at http://cla.calpoly.edu/ smarx/courses/431/431Exam_essays/431th.html; It would be interesting to follow up with alumni to see if or how they remember the experience; Recording the experiences of students in all fields via essays, images, and oral histories is an area that is rich with potential; seeing the experience of the land, people, and work through the eyes of students provides a valuable historiography.

${ }_{222}$ Images are available online at http://polyland.calpoly.edu/places/Swanland/studentsites/2003b/index.html ${ }^{223}$ Cal Poly Land, Textures of Swanton Pacific Ranch, available online at http://polyland.calpoly.edu/places/Swanland/studentsites/2003b/index.html 
James West t24 $^{24}$

"I tend to be a sounding board for various people's thoughts and their potential impacts on the outside world."225 James (Jim) West has lived in Swanton Valley for over 70 years (his entire life). His dedication to the sharing of everything Swanton to all that inquire has resulted in the enrichment of the work of the Santa Cruz community, as well as artists, scientists, and students from around the state and the world. His support and encouragement for the intellectual pursuits and successes of others is unparalleled.

Traversing Swanton Road is a more than 230-page work documenting the botany of the Scott Creek watershed, which includes more than 600 plants representing $10-12 \%$ of all plants in California and thus identifies the area as an ecological hotspot. ${ }^{226}$ Recently, a researcher at University of California, Santa Cruz has taken the work to prepare it for formal publication. The research questions posed in his work are the quality of the most prestigious research university scholars. He fosters, nurtures, and advocates for the educational development of undergraduates as well as MS and $\mathrm{PhD}$ research efforts. ${ }^{227}$ His mentoring of students and support of research at Swanton cannot be quantified. His academic and historical knowledge of Swanton make him irreplaceable.

\footnotetext{
${ }^{224} \mathrm{He}$ could also be described as an "intellectual artist of ecology." Personal communication, to author from Steve Auten, October 24, 2015.

${ }^{225} \mathrm{Jim}$ West, email to author, April 8, 2015.

${ }^{226}$ Traversing Swanton Road is available online at: http://arboretum.ucsc.edu/pdfs/TraversingSwanton.pdf; Images for 130 Scott Creek Watershed Flora are available online at http://spranch.calpoly.edu/plantlist.ldml?available $=y$. A student working with Jim West this summer said $14 \%$ to Swanton Pacific Ranch Operations Manager, Steve Auten. Personal communication, to author from Steve Auten, October 24, 2015.

${ }^{227}$ West's thoughts on evolutionary ecology, intellectual pursuits, an understanding of the world, and life in general continue to inspire those who had/have the opportunity to engage in conversation with him. Personal communication to the author by numerous students, staff, faculty, and community members throughout this research.
} 


\section{SUMMARY AND CONCLUSION}

The area known now as Swanton Pacific Ranch has a significant history that has changed the lives of those who have lived and continue to live there. The previous chapters provide Swanton's historical context and demonstrate the overlap of events, people, and the land. The people of the Swanton Valley promote a continuity of learning that continues long after the initial organization or learning is completed. Swanton has been described as "people living, learning, and sharing the landscape [as] pollinators."228

The result of a reciprocal relationship between land and people, fruitful and successful endeavors, valuable ventures, and innovative research has flourished. People have guided others to career paths and served as inspiration. The larger community is the fortunate beneficiary of the scholarly work and art. Many people describe their time at Swanton as transformative.

This work brings together information about Swanton Pacific Ranch and environs that is on the internet, faculty and staff desks, microfiche, video and computer hard drives, and in photographs, oral histories, newspapers, articles, books, ephemera, grey literature, people's memories and stories, archives, and garages. It organizes all of this information in a chronological manner from pre-history to the present. Chapter one delves deeply into the history of the Ohlone and results in historically significant information on the trade and food stuffs of this particular population. The chapter also demonstrates that

${ }^{228} \mathrm{Jim}$ West, email to author, April 8, 2015. 
history is being made every day and the Amah Mutsun are actively engaging in the preservation of their culture. ${ }^{229}$

Chapter two provides a brief outline of the 'established historical timeline' during early settlement and resource extraction of Swanton. However, the tried and true list of 'facts' becomes more cohesive as specific examples support those 'facts'. The fact that a stage coach ran through Swanton at one time comes alive with a story about an attempted murder of a driver. Al Smith, as 'just' the donor of Swanton Pacific Ranch, comes to life when as many facts and stories about him are brought together. He is seen through many lenses by different people and entities: Swanton residents, business partners, family, researchers, students, Cal Poly advancement, etc. This chapter is just the foundation for a more significant exploration of this man's life.

The final chapter provides a new view of Swanton, that of art and research. Only a few of the many artists, universities, and researchers are described over many decades. Filling in the gaps and bringing together the work that has been completed at Swanton is vital. Due to time constraints, one area of study has only been slightly touched and that is the lives of the former and current residents that are in the community. Their stories and

\footnotetext{
${ }^{229}$ An example is their work to have one of their most important archeological sites, the Quiroste Valley a section of Año Nuevo State Park, restricted to the public. Additional information about the area and its history is available from Hylkema and Cuthrell, "An Archaeological and Historical View of Quiroste Tribal Genesis," California Archaeology 5(2), (2013): 225-245. Available online:

https://www.firescience.gov/projects/10-1-09-3/project/10-1-09-

3_s5_HylkemaCuthrell2013_An_Archaeological_and_Historical_View_of_Quiroste_Tribal_Genesis.pdf; "Visit the Quiroste Valley with Mark Hylkema" available at http://sanmateocoastnha.org/pdfs/Quiroste\%20event.pdf; and "Quiroste Valley -- Restoring Sacred Ground Native Americans are restoring the ecology of an historic village on the San Mateo Coast," NBC Bay Area News, Aug. 8, 2015, http://www.nbcbayarea.com/news/local/Quiroste-Valley----Restoring-Sacred-Ground321137621.html.
} 
memories are slowly being preserved, but what knowledge will be lost if the pace of preservation is not hastened?

\section{Opportunities for Students}

One of the motivations for this project was to provide a springboard to engage students in new projects and research. In particular, this research serves to invite students who are not typically drawn to the Ranch-such as students in the College of Liberal Arts and College of Architectural and Environmental Design seeking nontraditional original subjects for theses and senior projects-to engage with Swanton Pacific Ranch. Giving students access to materials that others have not yet fully investigated provides that opportunity. Within the narratives' footnotes are an abundance of suggestions for further exploration and this thesis also offers an extensive list of sources in the bibliography.

A short list of suggested additional projects include:

- recording the world in art, music, or dance as seen through the eyes of a Swanton resident (College of Liberal Arts);

- collecting genealogical information by conducting oral histories with Swanton residents and reviewing family documentation (College of Liberal Arts/community partners);

- assisting with preservation and archival arrangement of paper-based and digital information in accessible collections (all majors/interdisciplinary partnerships); 
- providing structural documentation before and after Salo (1995) and Hartman and Isbell (2004) - there is already extensive documentation available upon which to build (College of Architectural and Environmental Design);

- documenting the architectural landscape of the ranch and its future development (College of Architectural and Environmental Design);

- examining past and current agribusiness endeavors (College of Agriculture, Food and Environmental Sciences);

- mapping any aspect over any time period of Swanton using geographic information systems (GIS) (all majors/interdisciplinary partnerships);

- developing interpretive exhibits (History/interdisciplinary partnerships);

- developing a GIS enabled historic tour recording (History/interdisciplinary partnerships);

- developing wayfinding for historic markers related to ranch history (Art and Design/Graphic Communications/interdisciplinary partnerships);

- examining the numerous and distinct spheres of communities divided along lines of ethnicity (College of Liberal Arts);

- compiling and reviewing the agricultural census records (Agribusiness/Business); and

- creating a usable database of information collected on water quality over the past two decades (Computer Science).

Hopefully, this work will inspire students to explore the history of the railroad, conduct oral histories, investigate ethnographic opportunities, review business histories, 
seek out the history of artworks, record familial relationships, and share the environmental processes of the land. 


\section{AFTERWARD}

Swanton has hundreds of storytellers from the past and present, and hundreds that will come forth in the future. They express their experiences and memories through visual, oral, and written traditions. The products of these expressions may not be recognized as traditional historiography but the work is invaluable to the historical record.

I want to thank all of the individuals and families that have provided me resources and spent time with me on this project over the past years. I am sorry that many of the items you have contributed to my extensive research archive are not reflected within this document. Please know that this thesis is just a first step in my long-term research. Your contributions are appreciated and will be shared in the future.

The Institutional Review Board (i.e. Human Subjects Committee) found the project to be in compliance with Public Health Service guidelines for the use of human subjects in research and exempt from further review. Approval was received January 17, 2014. Subsequent extensions were approved for the continuation of this project until July 16 , 2016. 


\section{BIBLIOGRAPHY230}

Anderson, Charles L. Santa Cruz for Homes: The Climate, Botany, Geology and Health of Santa Cruz and Vicinity. San Francisco, CA: Wallace W. Elliott and Co., 1879.

Baine, Tina. "Through the Potter's Wheel: Big Creek Pottery Looks Back." Santa Cruz Sentinel (Santa Cruz, CA), Mar. 26, 2011. http://www.santacruzsentinel.com/generalnews/20110326/through-the-potters-wheel-big-creek-pottery-looks-back.

Bean, John, and Harry W. Lawton. "Some Explanations for the Rise of Cultural Complexity in Native California with Comments on Proto-Agriculture and Agriculture." In Patterns of Indian Burning in California: Ecology and Ethnohistory. Edited by Lowell John Bean. Ramona, CA: Ballena Press, 1973, v-xvii.

Bean, Lowell John. The Ohlone Past and Present: Native Americans of the San Francisco Bay Region. Edited by Sylvia Brakke Vane, Ballena Press Anthropological Papers. Menlo Park, CA: Ballena Press, 1994.

Bennett, Mardi. Scouting in the Santa Clara Valley: The Seventy Year Adventure 1920-1990: The History of the Santa Clara County Council Boy Scouts of America. San Jose, CA: Santa Clara County Council Boy Scouts of America, 1990.

Bergtold, Peggy Conaway. "Los Gatos History Photo: Holiday Wishes from Al Smith." San Jose Mercury News (San Jose, CA), 2010. http://www.mercurynews.com/ci_16907006.

Bocek, Barbara R. "Ethnobotany of Costanoan Indians, California, Based on Collections

Boulé, Mary Null. Ohlone Tribe, California Native American Tribes. Vashon, WA: Merryant Publishers, 1992.

Bowman, Jacob Neibert. "Weights and Measures of Provincial California." California Historical Society Quarterly 30, no. 4 (1954): 315-338, doi: 10.2307/25156323.

Cal Poly College of Agriculture. 1998. Cal Poly AGRI-VIEW: Special Swanton Pacific Report. San Luis Obispo, CA.

Cal Poly Foundation. "Cal Poly Historical Timeline." Last modified 2001. http://www.calpoly.edu/ centen/time/index.html.

Cal Poly State University. "Nonindustrial Timber Management Plan (NTMP) Section III Plan Addendum." Swanton Pacific Ranch. 2008. http://spranch.calpoly.edu/files/ Swanton_NTMP/20080610_1-07NTMP-020SCR_Sec3.pdf.

${ }^{230}$ This is not a complete bibliography of materials reviewed by the author. It consists of the major works and reference materials integrated into this document. 
Swanton Pacific Ranch Management Plan. San Luis Obispo, CA: Cal Poly State University, 2004.

Swanton Pacific Ranch Management Plan. San Luis Obispo, CA: Cal Poly State University, 2011.

Cartier, Robert. "An Overview of Ohlone Culture." Santa Cruz County History -- Spanish Period and Earlier. 1991. http://www.santacruzpl.org/history/articles/248/.

Clark, Barbara Keeney, Patricia McDonald, Alverda Orlando, Frank Perry, Phil Reader, and Stanley D. Stevens, eds. Santa Cruz County History Journal. (Santa Cruz County History Journal). Santa Cruz, CA: Santa Cruz County Historical Trust, 1995.

Clark, Donald Thomas. Santa Cruz County Place Names: A Geographical Dictionary. Scott Valley, CA: Kestrel Press, 1986, 2nd Edition 2008.

Coe, Katherine. "Rare and Endangered Plants and Animals, Archaeological Resources and Property Owners Adjacent to the Swanton Pacific Ranch and Forestry." BS, Forestry and Natural Resources, Cal Poly, 1990.

Collins, Allen. "The Spreckels Era in Rio Del Mar, 1872-1922." Santa Cruz County History Places. 1995. http://www.santacruzpl.org/history/articles/407/.

Crespì, Juan. A Description of Distant Roads Original Journals of the First Expedition into California, 1769-1770. Translated by Alan K. Brown. San Diego, CA: San Diego State University Press, 2001.

Cronon, William. Changes in the Land: Indians, Colonists, and the Ecology of New England. 1st ed. New York, NY: Hill and Wang, 1983.

Cuthrell, Rob Q., Chuck Striplen, Mark G. Hylkema, and Kent G. Lightfoot. "A Land of Fire: Anthropogenic Burning on the Central Coast of California." In Contemporary Issues in California Archaeology, edited by Terry L. Jones and Jennifer E. Perry, 153-171. Walnut Creek, CA: Left Coast Press, 2012. https://www.firescience.gov/projects/10-1-093/project/10-1-09-3_JONES_CH_09.pdf.

Dana, Samuel Trask, and Myron Edward Krueger. California Lands: Ownership, Use, and Management. Washington, DC: American Forestry Association, 1958.

Davis, James Thomas. Trade Routes and Economic Exchange Among the Indians of California, Reports of the University of California Archaeological Survey. Berkeley, CA: University of California Archaeological Survey, 1961. 
Department, Cal Poly Communications. "Al Smith, 72." Cal Poly Report, 6 January 1994. http://digitalcommons.calpoly.edu/cgi/viewcontent.cgi?article=2072\&context=pao_rpt.

Dunn, Geoffrey. "The Death of a Poet " Santa Cruz County History - People, 1996. http://www.santacruzpl.org/history/articles/224/.

Elliott, Wallace W. Santa Cruz County, California. Illustrations descriptive of its scenery, fine residences, public buildings, manufactories, hotels, farm scenes, business houses, schools, churches, mines, mills, etc. ... With historical sketch of the county. San Francisco, CA: Wallace W. Elliott and Co., 1879.

Everson, William. The Rose of Solitude. 1st ed. Garden City, NY: Doubleday, 1967.

Fages, Pedro. A Historical, Political, and Natural Description of California by Pedro Fages, Soldier of Spain, Dutifully Made for the Viceroy in the Year 1775. Translated by Herbert Ingram Priestley. Berkley, CA: University of California Press, 1937.

Flores, R. "Amah Mutsun Relearning Program: Cultivating Native Wisdom - for the future generations." University of California Santa Cruz Arboretum. 2014. http://arboretum.ucsc.edu/education/relearning-program/index.html.

Francis, Phil. Santa Cruz County: A Faithful Reproduction in Print and Photography of its Climate, Capabilities and Beauties. San Francisco, CA: Press of H.S. Crocker, 1896.

Freeburg, Jane, ed. Cal Poly: The First Hundred Years. San Luis Obispo, CA: Robert E Kennedy Library, California Polytechnic State University, 2001.

Fuller, Dana, Diane R. Whitcomb, Charles W. Whitcomb, and Rich Melvin. Swanton Pacific. LaGrange, IL: Machines of Iron. Visual Material, 2001.

Groff, Frances A. "Exposition Moths: Snapshots of the People Who Make the Joy Zone." Sunset Magazine: The Pacific Monthly 35, (1915): 133-148.

Guzman, Kara. "Santa Cruz County Land Trust Restores Native American Stewardship." Santa Cruz Sentinel (Santa Cruz, CA), Nov. 28, 2014. http://www.santacruzsentinel.com/ general-news/20141128/santa-cruz-county-land-trust-restores-native-americanstewardship.

Hamman, Rick. "140 Years of Railroading in Santa Cruz County (Santa Cruz County History Transportation)." Santa Cruz Public Libraries, 2000. http://www.santacruzpl.org/ history/articles/198/.

Harrison, Edward Sanford. History of Santa Cruz County California. San Francisco, CA: Pacific Press Publishing Company, 1892. 
Hartman, Tanner O., and Clinton J. Isbell. "Structures of Swanton Pacific Ranch." Class Project FNR 418: Applied GIS, Natural Resources Management Department, California Polytechnic State University, 2004.

Heizer, Robert Fleming, ed. The Costanoan Indians. Vol. 18, Local History Studies. Cupertino, CA: California History Center, 1974.

Heizer, Robert Fleming, and Mary Anne Whipple, eds. The California Indians: A Source Book. Second ed. Berkeley, CA: University of California Press, 1971.

Hoffman, Ogden. Reports of Land Cases Determined in the United States District Court for the Northern District of California: June Term, 1853 to June Term, 1858, Inclusive, San Francisco, CA: N. Hubert, 1862.

Hoover, Mildred Brooke. Historic Spots in California. Stanford, CA: Stanford University Press, 1948.

Hughes, J. Donald. "Global Dimensions of Environmental History." Pacific Historical Review 70, no. 1 (2001): 91-101.

Hughes, Richard E. "Mosaic Patterning in Prehistoric California-Great Basin exchange." In Prehistoric Exchange Systems in North America, 363-383. New York, NY: Plenum Press, 1994.

Hylkema, Mark G., and Rob Q. Cuthrell. "An Archaeological and Historical View of Quiroste Tribal Genesis." California Archaeology 5, no. 2 (2013): 225-245. https://www.firescience.gov/projects/10-1-09-3/project/10-1-093_s5_HylkemaCuthrell2013_An_Archaeological_and_Historical_View_of_Quiroste _Tribal_Genesis.pdf.

Jackson, Thomas L., and Jonathon E. Ericson. "Prehistoric Exchange Systems in California." In Prehistoric Exchange Systems in North America, edited by Timothy G. Baugh and Jonathon E. Ericson, 385-415. New York, NY: Plenum Press, 1994.

Jeffers, Robinson. Granite and Cypress: Rubbings from the Rock. Santa Cruz, CA: Lime Kiln Press, University of California at Santa Cruz, 1975.

Jensen, Lisa. "Incandescent Moments." Santa Cruz Good Times (Santa Cruz, CA), Mar. 25, 2011. http://www.gtweekly.com/index.php/santa-cruz-arts-entertainment-lifestyles/santacruz-arts-entertainment-/2318-incandescent-moments.html.

Jepson, Willis Linn. The Jepson Manual: Higher Plants of California. Berkeley, CA: University of California Press, 1993. 
Johnson, Eric. "Big Creek Lumber Company." In Redwood Logging and Conservation in the Santa Cruz Mountains: A Split History, (2014): 190-202. Santa Cruz, CA: Santa Cruz Museum of Art and History McPherson Center.

Keeley, Jon E. "Native American Impacts on Fire Regimes of the California Coastal Ranges." Journal of Biogeography 29, no. 3 (2002): 303-320. http://www.tribesandclimatechange.org/documents/nccc/nccc_449.pdf.

Koch, Margaret. Santa Cruz County: Parade of the Past. Santa Cruz, CA: Western Tanager Press, 1973, Reprint 1991.

Kroeber, A. L. "Elements of Culture in Native California." The California Indians: A Source Book. Second ed., In Heizer, Robert Fleming, and Mary Anne Whipple, eds., 3-65. Berkeley, CA: University of California Press, 1971.

Langston, Nancy. Forest Dreams, Forest Nightmares: The Paradox of Old Growth in the Inland West, Weyerhaeuser Environmental Book. Seattle, WA: University of Washington Press, 1995.

Levy, Richard. "Costanoan." In Handbook of North American Indians 8, edited by Robert Fleming Heizer, 485-495. Washington, DC: Smithsonian Institution, 1978.

Lewis, Henry T. "The Role of Fire in the Domestication of Plants and Animals in Southwest Asia: A Hypothesis." Man 7, no. 2 (1972): 195-222.

Patterns of Indian Burning in California: Ecology and Ethnohistory. Edited by Lowell John Bean. Ramona, CA: Ballena Press, 1973.

Lightfoot, Kent G, and Otis Parrish. California Indians and Their Environment: An Introduction (California Natural History Guide). Berkeley, CA: University of California Press, 2009.

Lopez, Valentin. "Healing from Historical Trauma: The Journey of the Amah Mutsun." News from Native California 28, no. 2 (2015): 65-69. http://newsfromnativecalifornia.com/store/issues/282/.

Maggi, Franklin. "Revised Guidelines for Historic Reports." Historic Report: Prepared According to the City of San José. Feb. 26, 2010. https://www.sanjoseca.gov/ DocumentCenter/Home/View/668.

Historic Report: Orchard Supply Hardware, San Jose, CA: Archives and Architecture, LLC, 2012.

Margolin, Malcolm. The Ohlone Way: Indian Life in the San Francisco-Monterey Bay Area. 
Berkeley, CA: Heyday Books, 1978.

Martin, Edward. History of Santa Cruz County, California, with Biographical Sketches. Los Angeles, CA: Historic Record Company, 1911, Reprint 2014.

Martin, Steve L. "The Use of Marah macrocarpus by the Prehistoric Indians of Coastal Southern California." Journal of Ethnobiology 29, no. 1 (2009): 77-93. http://www.researchgate.net/publication/232690327_The_Use_of_Marah_Macrocarpus_ by_the_Prehistoric_Indians_of_Coastal_Southern_California.

Marx, Steven, ed. Cal Poly Land: A Field Guide. Santa Maria, CA: Accurate Color Printing, 2002.

Massaro, Karen Thuesen. "Big Creek Pottery. " Ceramics Monthly, April 2011. http://ceramicartsdaily.org/ceramics-monthly/ceramics-monthly-april-2011/.

Big Creek Pottery, A Social History of a Visual Idea, 1967-1983: An oral history interview with Bruce and Marcia McDougal. Santa Cruz, CA: The Museum of Art and History McPherson Center Production, 2011.

McDougal, Bruce. "Kick Wheel Plan.” Whole Earth Catalogue. 1974: 1-14. http://ceramicartsdaily.org/wp-content/uploads/2011/03/mcdougalkickwheelplan8x11.pdf.

. "Welcome to the Big Creek Pottery Website." Accessed July 20, 2014. http://www.bigcreekpottery.org/.

McDougal, Heather 2009. "Big Creek Pottery: A Memory Log for One of the First Summer Craft Schools." January 22, 2009. https://bigcreekpottery.wordpress.com/about/trackback/.

McKay, Rachel, ed. Santa Cruz County History Journal. Vol. 1, Santa Cruz County History Journal. Santa Cruz, CA: Santa Cruz County Historical Trust, 1994.

McNeill, John R. "Observations on the Nature and Culture of Environmental History." History and Theory 42, no. 4 (2003): 5-43.

Milliken, Randall. A Time of Little Choice: The Disintegration of Tribal Culture in the San Francisco Bay Area, 1769-1810, Ballena Press Anthropological Papers. Menlo Park, CA: Ballena Press, 1995.

Monterey Bay Council of the Boy Scouts of America. "Camp Totocano." Monterey Bay Area Council, Apr. 13, 2015, http://www.himlyn.com/pico.blanco/totocano.html.

National Park Service, U.S. Department of the Interior. Golden Gate National Recreation Area. "Fort Mason History Walk," n.d., http://www.nps.gov/goga/planyourvisit/upload/sg- 
foma.pdf.

Okrand, Marc. "Mutsun Grammar." Ph.D. Dissertation, Linguistics, University of California Berkeley, 1977, http://linguistics.berkeley.edu/ survey/documents/dissertations/okrand1977.pdf.

Orchard Supply Hardware. "About Us." Orchard Supply Hardware, 2015, http://www.osh.com/ aboutUs.

Orlando, Alverda. "The Wildest Ride in Town Davenport's Cement Plant Railroad System." In Santa Cruz County History Journal, 17-24. Santa Cruz, CA: Santa Cruz County Historical Trust, 1995.

Parker, Ann. "Smart Money: The Century-old Davenport Cash Store has a Colorful History and a Menu to Match." Metro Santa Cruz (Santa Cruz, CA). 2003. http://www.metroactive.com/ papers/cruz/02.19.03/dining-0308.html.

Peattie, Donald Culross. A Natural History of Western Trees. Boston, MA: Houghton Mifflin, 1953.

Peck, Willys. "Albert B. Smith, Railroad Buff, Teacher, Head of Orchard Supply." San Jose Mercury News (San Jose, CA), Dec. 22 1993, 5B.

Perry, Frank, Robert W. Piwarzyk, Michael D. Luther, Alverda Orlando, Allan Molho, and Sierra L. Perry. Lime Kiln Legacies: the History of the Lime Industry in Santa Cruz County. Santa Cruz, CA: Santa Cruz Museum of Art and History McPherson Center, 2007.

Poetry Foundation. "Biography of William Everson: 1912-1994." n.d., http://www.poetryfoundation.org/bio/ william-everson.

Rice, Walter E. and Karl Hovanitz. The Saga of the Overfair Railway Pacifics: from Panama to Poly. San Luis Obispo, CA: Silverado Publishing, 1999.

Robinson, Lisa. "The Mattei Family Photograph Album Collection." A Split History: Redwood Logging and Conservation in the Santa Cruz Mountains 7, (2004): 161.

Robinson, William W. Land in California: The Story of Mission Lands, Ranchos, Squatters, Mining Claims, Railroad Grants, Land Scrip, Homesteads, Chronicles of California. Berkeley, CA: University of California Press, 1948.

Rumsey, Ken. "William Everson." The Beat Page, n.d., http://www.rooknet.net/beatpage/ writers/everson.html.

Salo, Glenn W. A Survey of the Buildings on the Swanton Pacific Ranch. San Luis Obispo, CA: 
California Polytechnic State University, 1995.

Sample, L. L. Trade and Trails in Aboriginal California, Reports of the University of California Archaeological Survey. Berkeley, CA: University of California Archaeological Survey, 1950.

Santa Cruz Public Library. "About this Database." Santa Cruz Newspaper Clipping File, n.d. http://www2.santacruzpl.org/history/clippingfile/.

Scalhotrod. "BracherOSH1942.jpg." Orchard Supply Company, Ltd., Accessed September 8, 2012. http://en.wikipedia.org/wiki/File:BracherOSH1942.jpg\#filehistory.

Shanklin, James. Report of the Surveyor-General of the State of California from August

Shaw, Frederic Joseph. Little Railways of the World. Berkeley, CA: Howell-North Press, 1958.

Silver, Timothy. A New Face on the Countryside: Indians, Colonists, and Slaves in South Atlantic Forests, 1500-1800, Studies in Environment and History. New York, NY: Cambridge University Press, 1990.

Smith, Albert B. "Permanent Cover Crops in California Orchards." B.S. Senior Project, Crops Production, Cal Poly, 1944.

Staff Writer. "Advertisement." San Francisco Call (San Francisco, CA), Jan. 4, 1909. http://cdnc.ucr.edu/cgi-bin/cdnc?a=d\&d=SFC19090104.2.47.2\&srpos=13\&e=0401-1909----190-en--20--1--txt-txIN-Ocean+Shore+Railway-ADVERTISEMENT--1909--\#.

. "Attempted Murder of Stagecoach Driver." Daily Alta California (San Francisco, CA), Aug. 23, 1872.

"Lockheed Fire Burns 1,000 Acres Wednesday Night - Evacuations Ordered, 250 Structures Threatened." Santa Cruz Sentinel News (Santa Cruz: CA), Aug. 12, 2009. http://www.santacruzsentinel.com/general-news/20090812/lockheed-fire-burns-1000acres-wednesday-night-evacuations-ordered-250-structures-threatened.

"Martha Neilsen (1929-2013) Obituary." San Jose Mercury News (San Jose, CA), Jan. 14, 2014, http://www.legacy.com/obituaries/mercurynews/obituary.aspx? pid=169080172.

"United States Surveyor General's Office San Francisco." Sacramento Daily Union (Sacramento, CA), Jan. 1, 1868. http://cdnc.ucr.edu/cgibin/cdnc?a=d\&d= SDU18680101.2.26\#.

Stechman, John V., and California Polytechnic State University Foundation. An Illustrated 
History of Land Acquisition and Development for Agricultural Education: California Polytechnic State University, San Luis Obispo County, California, 1985. San Luis Obispo, CA: El Corral Publishing, 1985.

Stephens, S.L., and N.G. Sugihara. "Fire Management and Policy Since European Settlement." In Fire in California's Ecosystems, edited by N.G. Sugihara, J.W. van Wagtendonk, K.E. Shaffer, J.A. Fites-Kaufmann and A.E. Thode A.E., 431- 443. Berkeley, CA: University of California Press, 2006.

Stevens, Stanley D., ed. The Society of California Pioneers of Santa Cruz County: With Biographies and Portraits. Vol. 4, Santa Cruz County History Journal. Santa Cruz, CA: Museum of Art and History McPherson Center, 1998.

Stodder, Ann Lucy Wiener. Mechanisms and Trends in the Decline of the Costanoan Indian Population of Central California: Nutrition and Health in Pre-contact California and Mission Period Environments. Salinas, CA: Coyote Press, 1986.

Sudlow, Robert. Landscapes in Kansas: Paintings. Lawrence, KS: University Press of Kansas, 1987.

. Passing Seasons: Paintings by Robert Sudlow: December 12, 1993-February 13, 1994. Lawrence, KS: Wichita Art Museum, 1993.

Spiritual Journeys: The Art of Robert Sudlow. Kansas City, MO: Exhibits USA, 2002.

Teixeira, Lauren S. "Access to Information on the Costanoan/Ohlone Indians of the San Francisco and Monterey Bay Area: A Descriptive Guide to Research." MLS Master's, Library and Information Science, San Jose State University, 1991.

. The Costanoan/Ohlone Indians of the San Francisco and Monterey Bay Area: A Research Guide. Menlo Park, CA: Ballena Press, 1997.

Unknown. Hand Drawn Map of Diseño del Rancho Agua Puerca y las Trancas: Santa Cruz County, California. 1867.

United States Department of Agriculture (USDA). "Plant Fact Sheets: California Hazelnut Corylus cornuta subsp. californica." Accessed March 8, 2015. https://plants.usda.gov/ factsheet/pdf/ss_cococ.pdf.

"Plant Fact Sheets: California Laurel - Umbellularia californica." USGS Plants Database. Accessed March 1, 2015. https://plants.usda.gov/plantguide/pdf/cs_umca.pdf.

"Plant Fact Sheets: Pacific Madrone - Arbutus menziesii." USGS Plants Database. Accessed March 1, 2015. https://plants.usda.gov/plantguide/pdf/cs_arme.pdf. 
United States Surveyor General's Office San Francisco. Sacramento Daily Union (Sacramento, CA), Jan. 1, 1868. http://cdnc.ucr.edu/cgi-bin/cdnc?a=d\&d=SDU18680101.2.26\#.

Van De Werfhorst, Laurie C. "Some of the Stone Tools Found at the Scott Valley Site." Santa Cruz Public Library, n.d. http://www.santacruzpl.org/history/articles/260/.

Viets, Jack. "Cal Poly Given a Ranch - If It Keeps Developers Away." The San Francisco Chronicle (San Francisco, CA), Feb. 19, 1987.

Wagner, Jack Russell. The Last Whistle: Ocean Shore Railroad. Berkeley, CA: Howell-North Books, 1974.

Warrick, Sheridan F., ed. The Natural History of the UC Santa Cruz Campus. Vol. 11, Environmental Field Program, University of California Santa Cruz. Santa Cruz, CA: University of California Santa Cruz, 1982.

West, James A. "Traversing Swanton Road." University of California Santa Cruz Arboretum. 2015. http://arboretum.ucsc.edu/pdfs/TraversingSwanton.pdf.

Willey, H.I. "Report of the Surveyor-General of the State of California, From August 1, 1884, to August 1, 1886." Office of Surveyor-General State of California. Sacramento, CA: State Office, 1886.

Willey, Samuel H. History of Santa Cruz County, California: Together With Personal Notices of Prominent Citizens. San Francisco, CA: Wallace W. Elliott \& Co. Biography, 1879.

Williams, Gerald W. "References on the American Indian Use of Fire in Ecosystems." Pacific Northwest Region, 2005. http://lakestatesfiresci.net/docs/AmericanIndianFireUse.pdf.

Worster, Donald. "World Without Borders: The Internationalizing of Environmental History." Environmental Review: ER 6, no. 2 (1982): 8-13.

Wright, Thomas, Bennett M. V., and Healy L. B. "Map of Santa Cruz County, 1880-81." Santa Cruz: County Surveyors, Santa Cruz Co, 1881. http://library.ucsc.edu/maps/map-ofsanta-cruz-county-1880-81.

Yamane, Linda, ed. A Gathering of Voices: The Native Peoples of the Central California Coast. Vol. 5, Santa Cruz County History Journal. Santa Cruz, CA: Museum of Art and History McPherson Center, 1998. 


\section{APPENDICES}




\section{APPENDIX A: THE SEASIDE SCHOOL IN PHOTOGRAPHS}

The first school in Santa Cruz County was established in 1853 with twenty-five pupils, but by 1891 there were 63 school houses and 3733 students, all between the ages of $5-17 .{ }^{231}$ Seaside students mostly came from Scott Creek drainage while a few came from north and south along the coast, including from the town of Davenport. ${ }^{232}$

The first Seaside District school was established 1880 on the Phillipini ranch between the Staub and Chandler homes, abandoned in 1890, and rebuilt as the Seaside School at the Post Place stage stop near the Seaside Post Office. In 1897, the building was placed on a sled, taken up the Gianone Hill and placed between Post Place and Swanton, then abandoned in 1909, and a new schoolhouse was built on Scott Creek at the foot of Gianone Hill about a mile north of Swanton; the Gianone family charged the district $\$ 12$ a year in rent. One of the students, Lillie Mattei (spelled Lily in other documents), became a teacher and returned in 1929 to teach $1^{\text {st }}-6^{\text {th }}$ grades until $1935 .{ }^{233}$ Among the pupils of those years, there were a number of residents whose descendants continue to live on Swanton today including the Wests, Wilsons, McCrays, and Marie Pini and her brother Gino (later the Police Chief of San Santa Cruz). ${ }^{234}$

In 1961, the school was closed and students were sent to Davenport's Pacific School. These Swanton students included: third generation pupils from the West,

\footnotetext{
${ }^{231}$ Harrison, 1892, 205.

232 "A History of Seaside School Santa Cruz County California 1880-1961," compiled by Hulda Hoover McLean, March 1990,1; The remainder of this text is directly quoted or slightly paraphrased from McLean. ${ }^{233}$ Ibid., 1-2.

${ }^{234}$ Ibid., 3.
} 
Gianone, and Fallise families; and fourth generation children from the Staub, Trumbo, and McCrary families. ${ }^{235}$

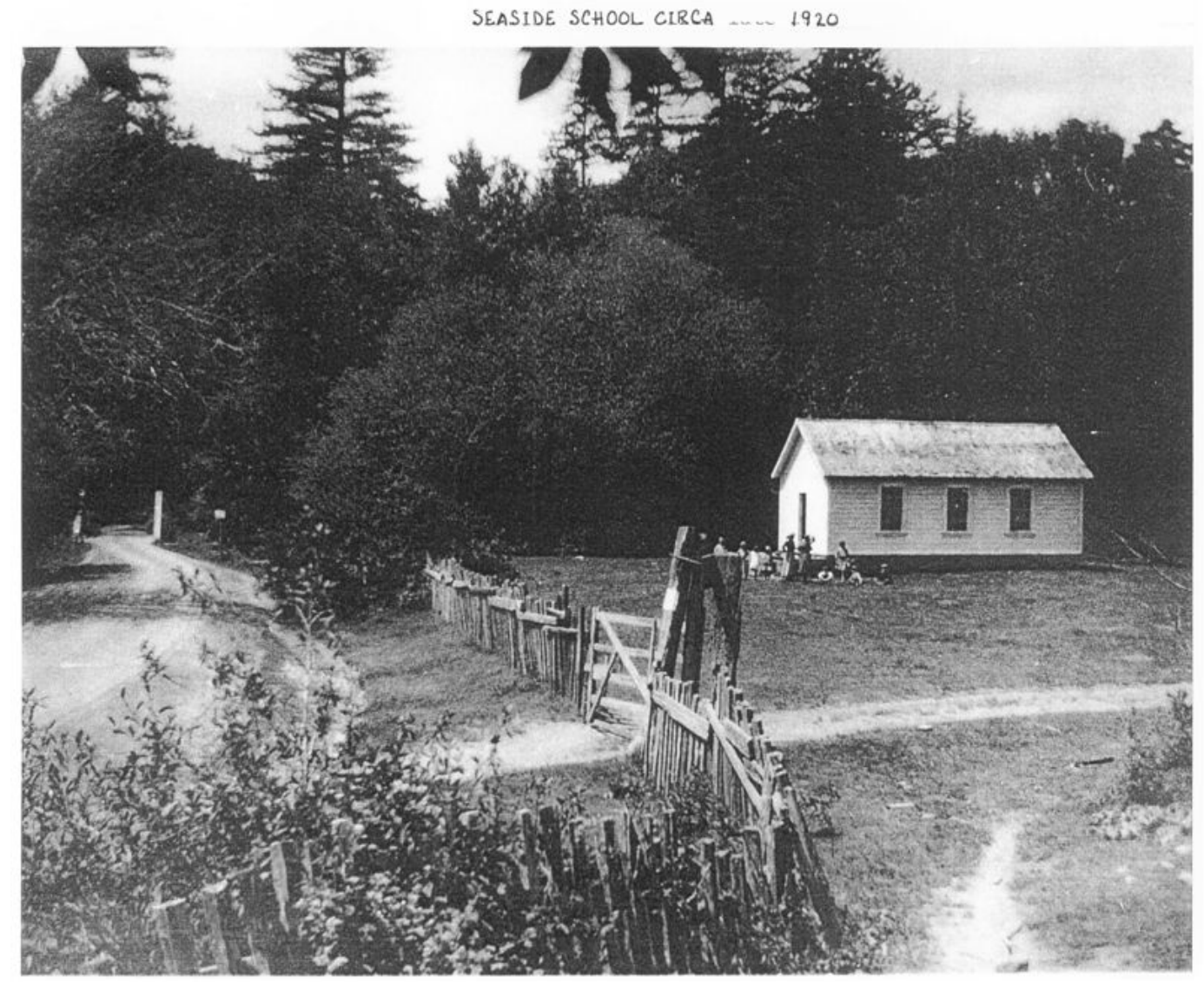

Figure 30: Seaside School, circa 1920. Courtesy of Marie Pini Stoner.

235 lbid., 5-6. 


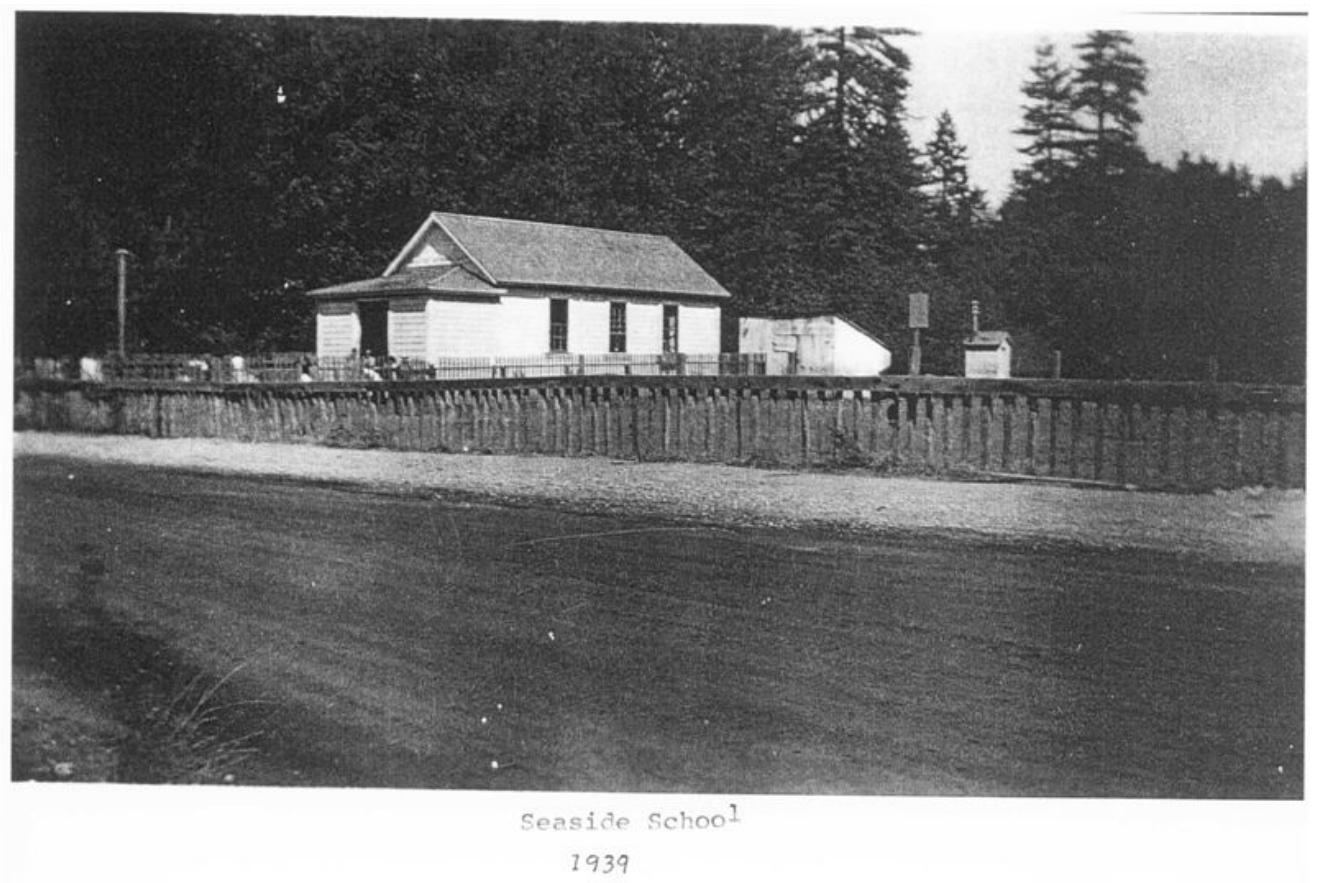

Figure 31: Seaside School, 1939. Courtesy of Marie Pini Stoner. 


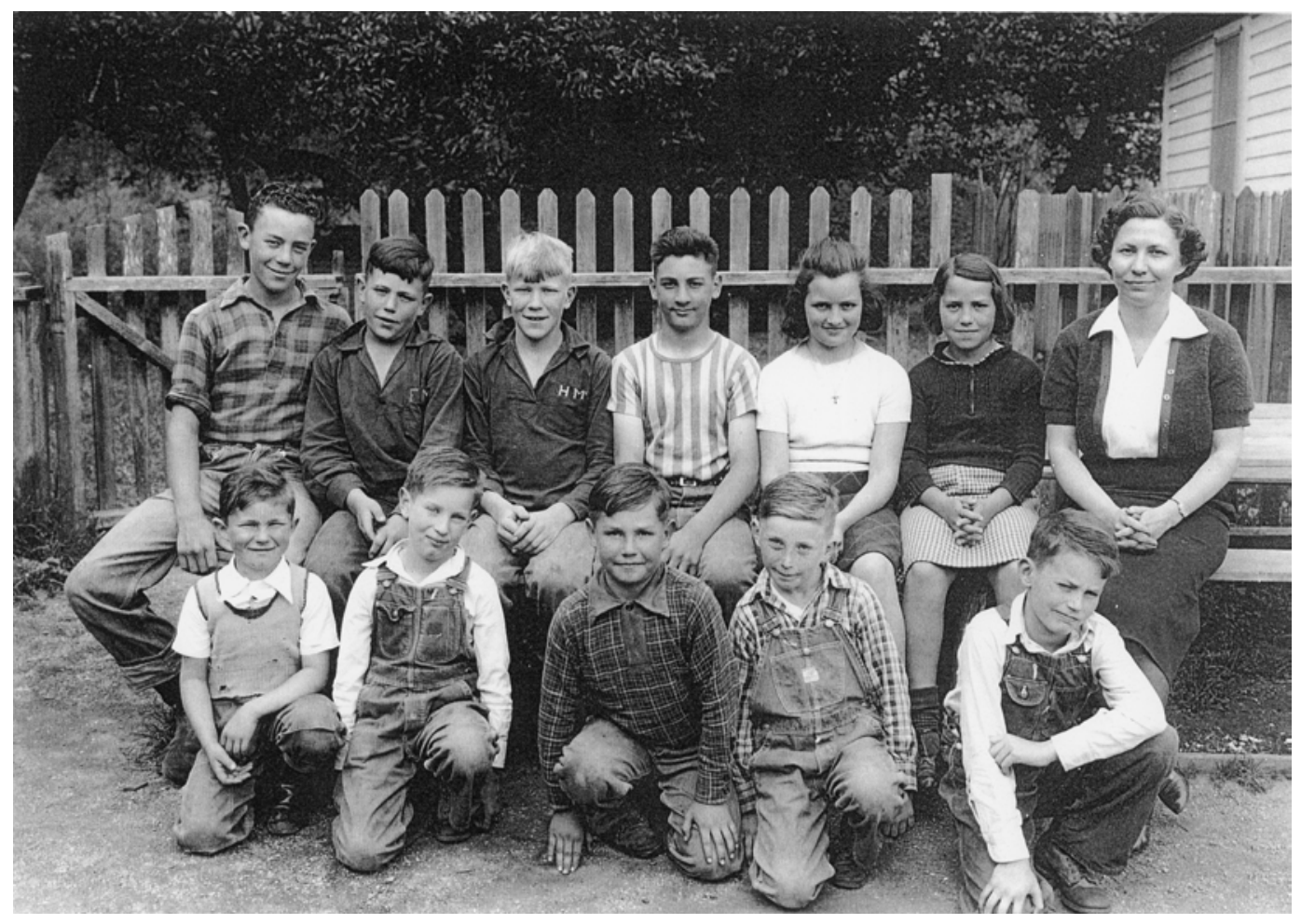

Figure 32: Seaside School Second Grade Class Photo, 1937. From left to right: back row, Geno Pini, Lud and Bud McCray, John Modolo, Bette Gianone, Enes Pini, Mrs. Wilson (teacher); front row, unidentified, Bill Wilson, unidentified, Dick West, Ben Wilson. Courtesy of Kim Stoner. 


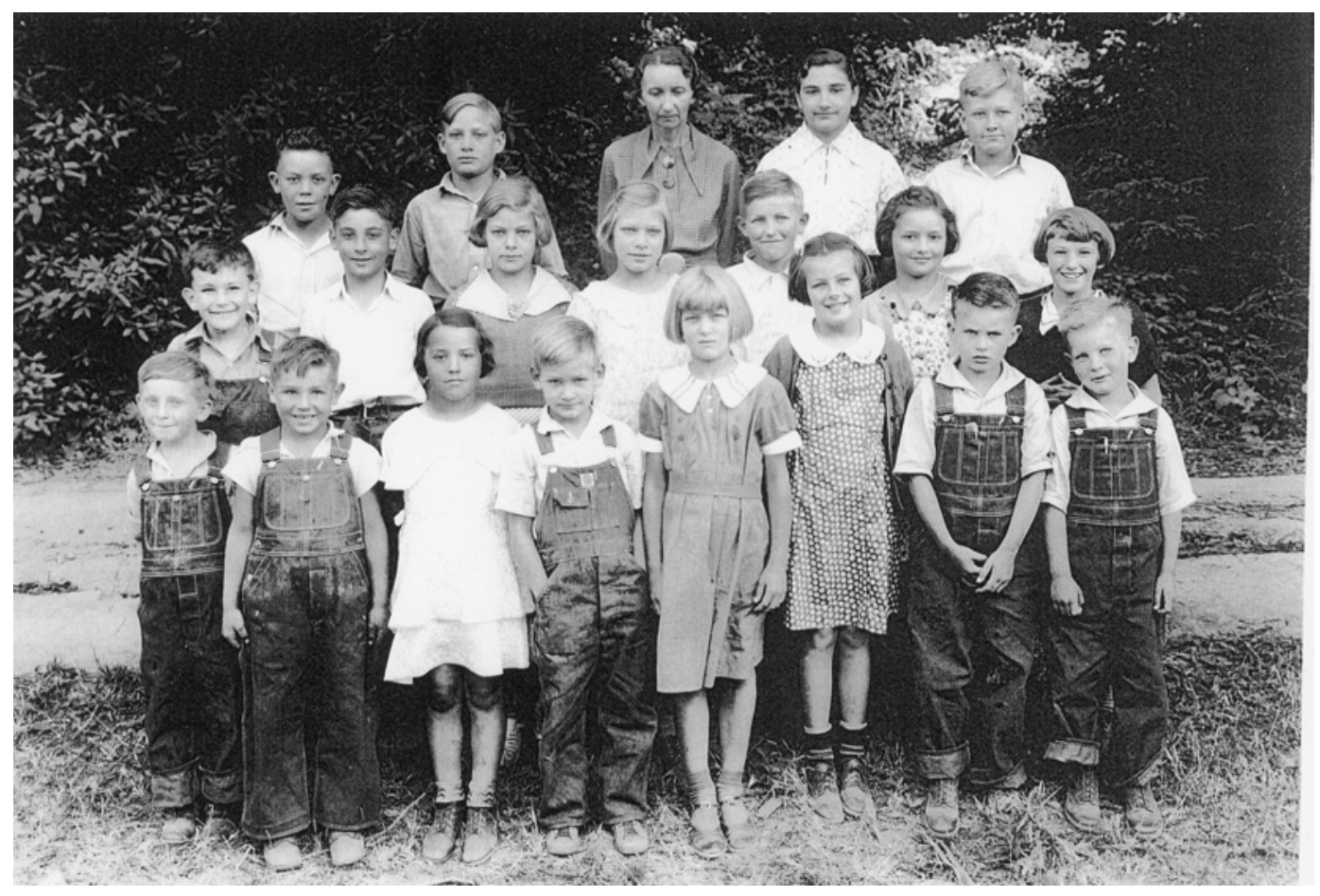

Figure 33: Seaside School Class Photo, n.d. From left to right: back row, Geno Pini, teacher, (?) Cook, Mary Modoho, Jack Shaw(?); second row, unidentified, John Madolo (?), unidentified, unidentified, Donald McCrary, Bette Gianone, Iris McCrary; first row, Dick West, unidentified, Enes Pini, unidentified, unidentified, Florence (?), Ben Wilson, Bill Wilson. Courtesy of Kim Stoner. 


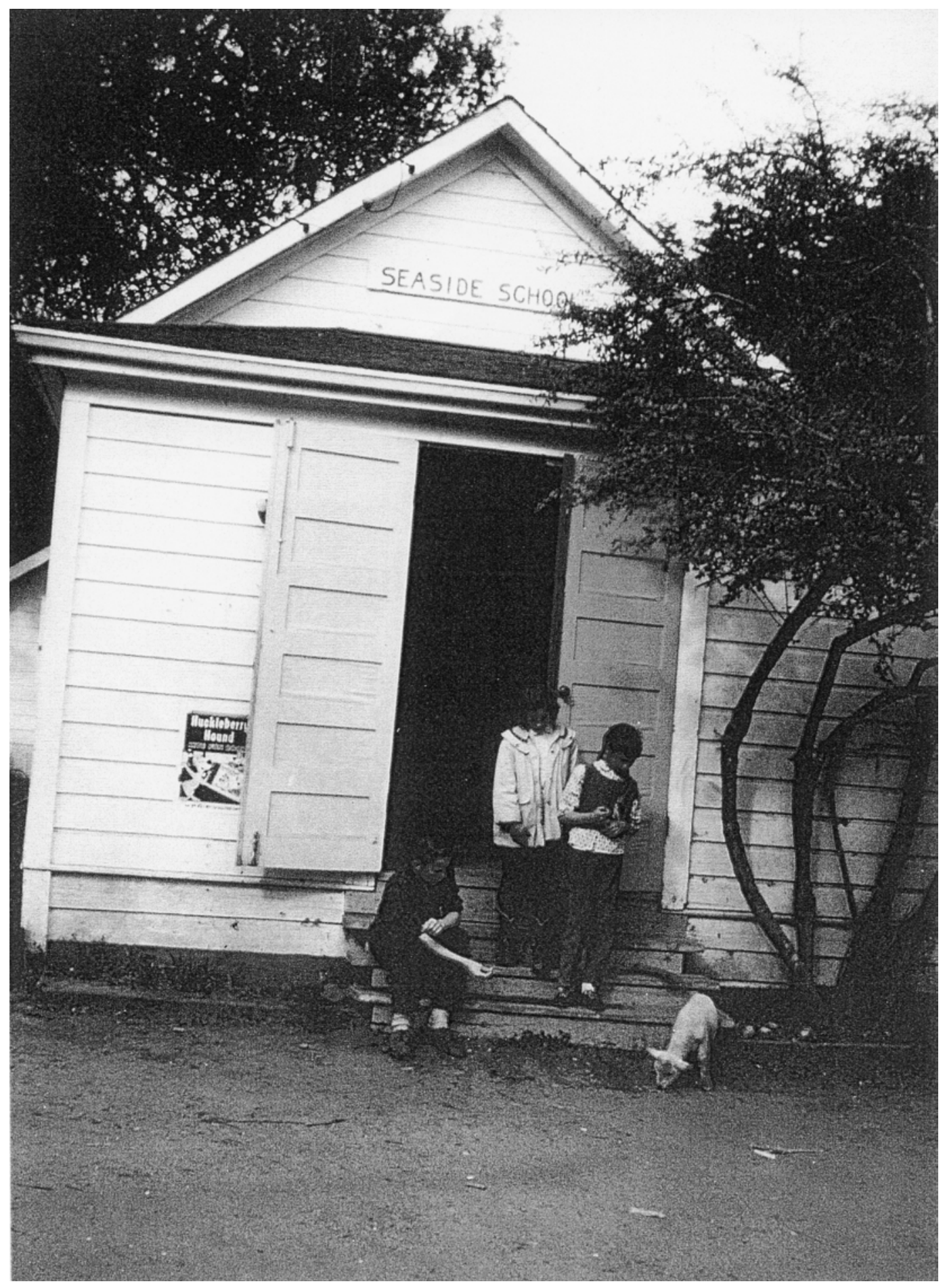

Figure 34: Seaside School, n.d. The individuals in this photo have not been identified and the source of this image has been lost. 


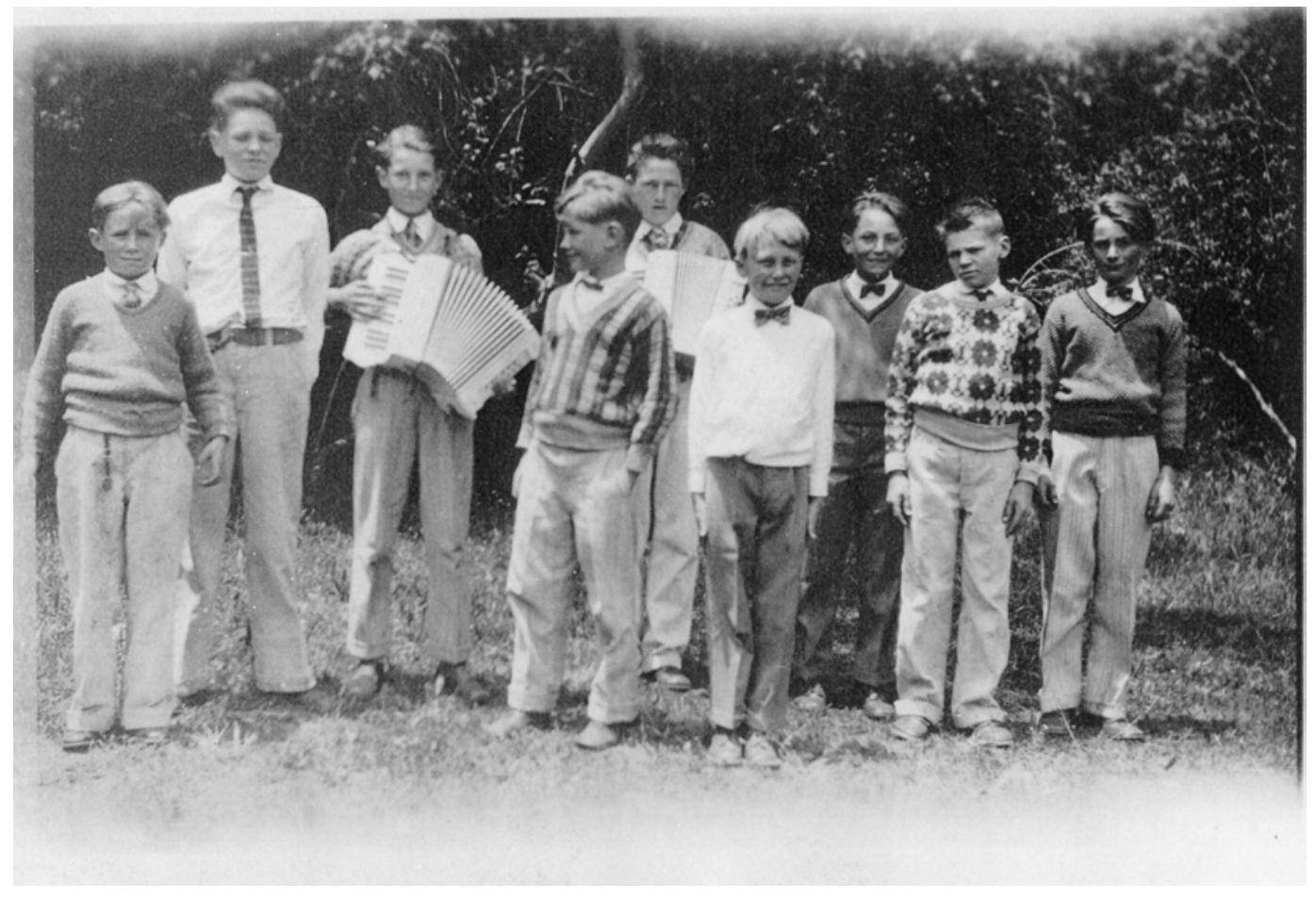

Figure 35: Seaside School, n.d. Courtesy of Kim Stoner.

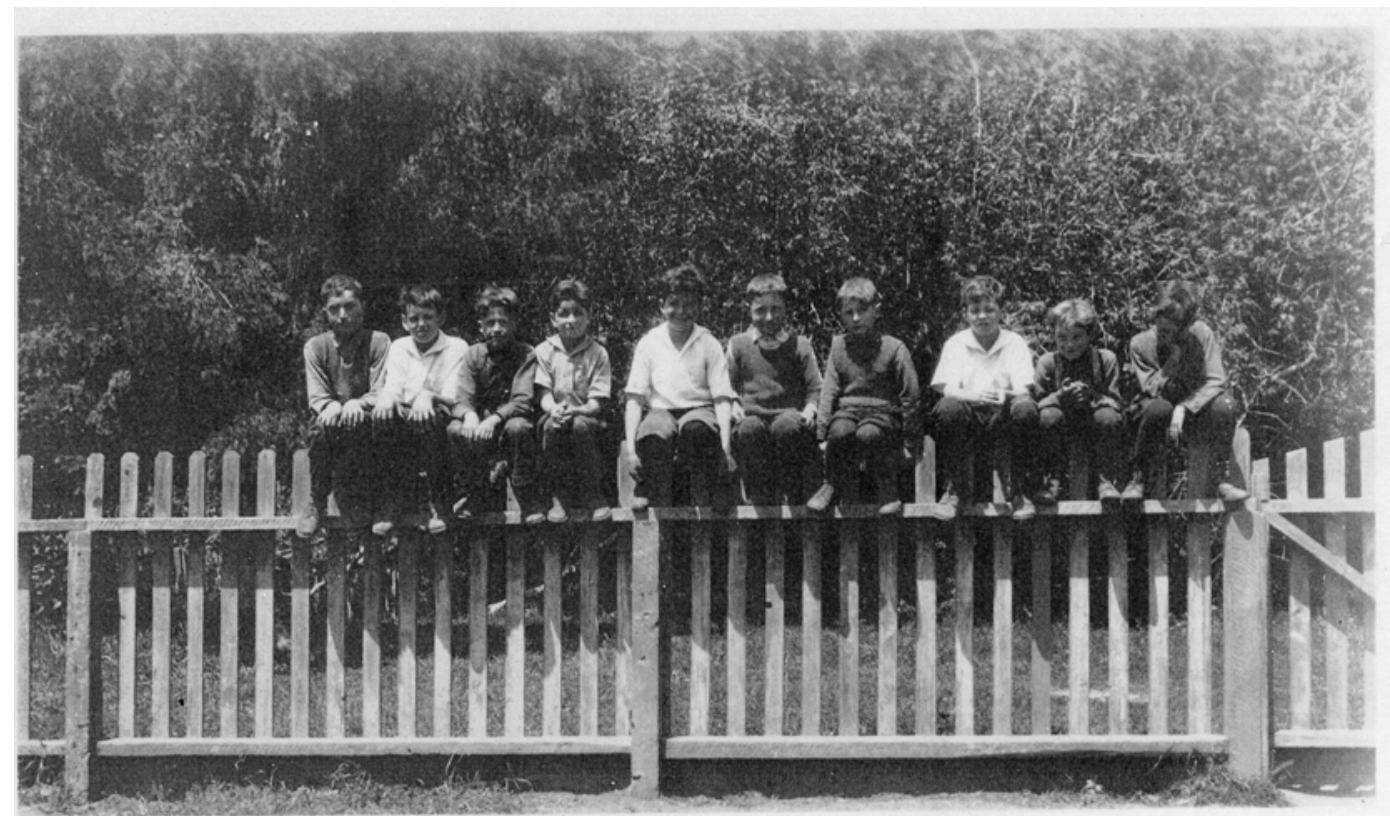

Figure 36: Seaside School, n.d. Courtesy of Kim Stoner. 


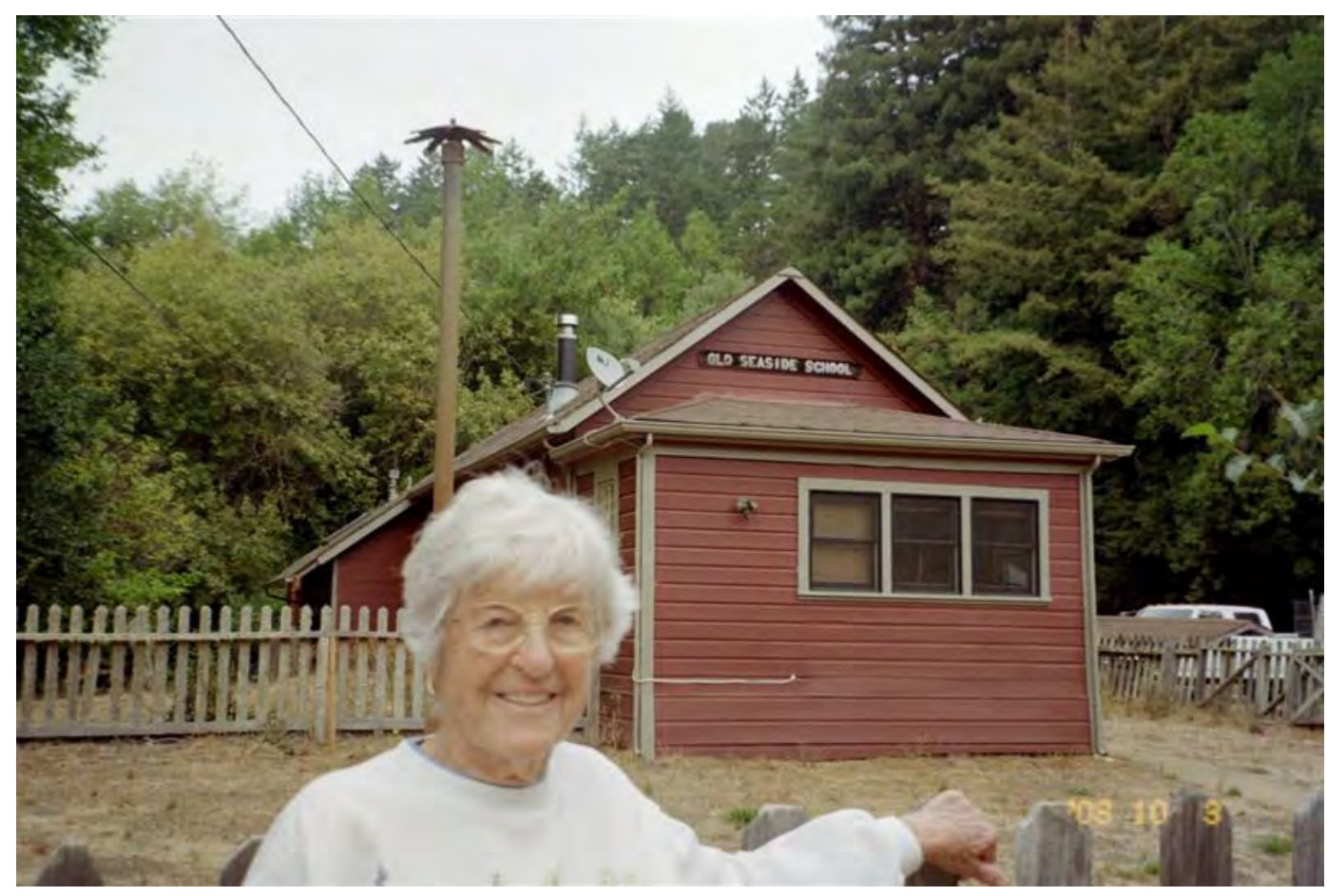

Figure 37: Seaside School, August 31, 2014, Marie Pini Stoner. From the author's personal collection. 


\section{APPENDIX B: PINI RANCH AND FAMILY}

Marie Pini Stoner was born in 1923 to Virginia and Celest Pini. Her parents were both from the same town in Italy, but they met in Santa Cruz, California, after they had immigrated to the United States. Shortly after her birth, the family moved to Swanton. Her family were ranchers growing artichokes and Brussels sprouts. They leased land in an area of Swanton called Siberia (pronounced SEE-BERRY-AH). Mrs. Stoner lived there until she was 13 years old. She was the oldest of three, with siblings Geno J. Pini (b.1926) and Edith Olivia Pini (b. 1929). To get to school they walked about a mile and a half down from Siberia and a mile and a half back - about 45 minutes each way. Marie Pini Stoner was interviewed by the author for more than an hour on February 1, 2014, in her Santa Cruz home. ${ }^{236}$

${ }^{236}$ Mrs. Stoner's oral history transcript will be published in a forthcoming manuscript by the author, Recording the Stories of Swanton. 


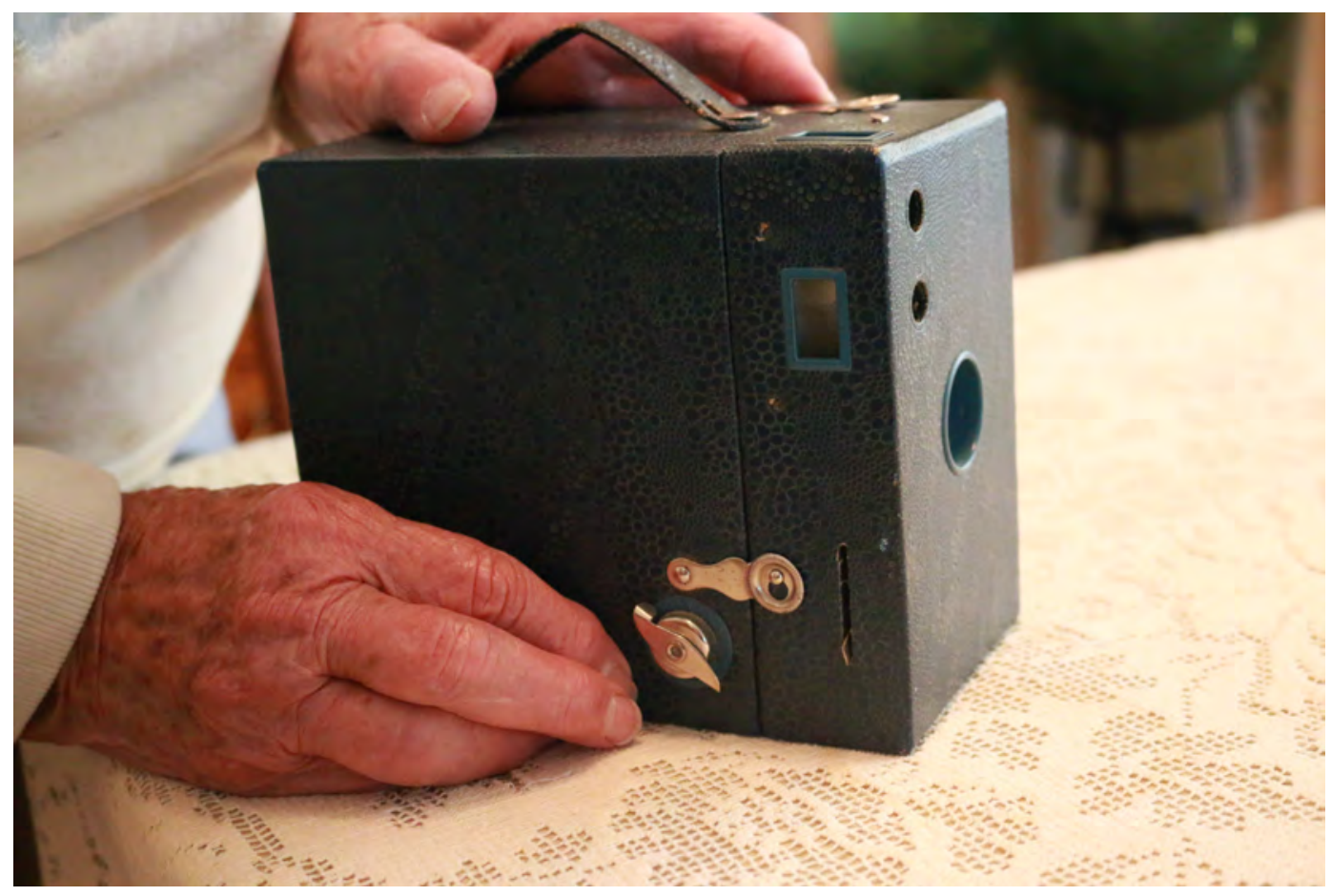

Figure 38: Pini Box Camera. Marie Pini Stoner's box camera with which some of the pictures in this manuscript were taken. It was a gift from her Confirmation sponsor; she remembers being 12 or 14 at the time. Marie Pini Stoner, interview by author, February 1, 2014. 


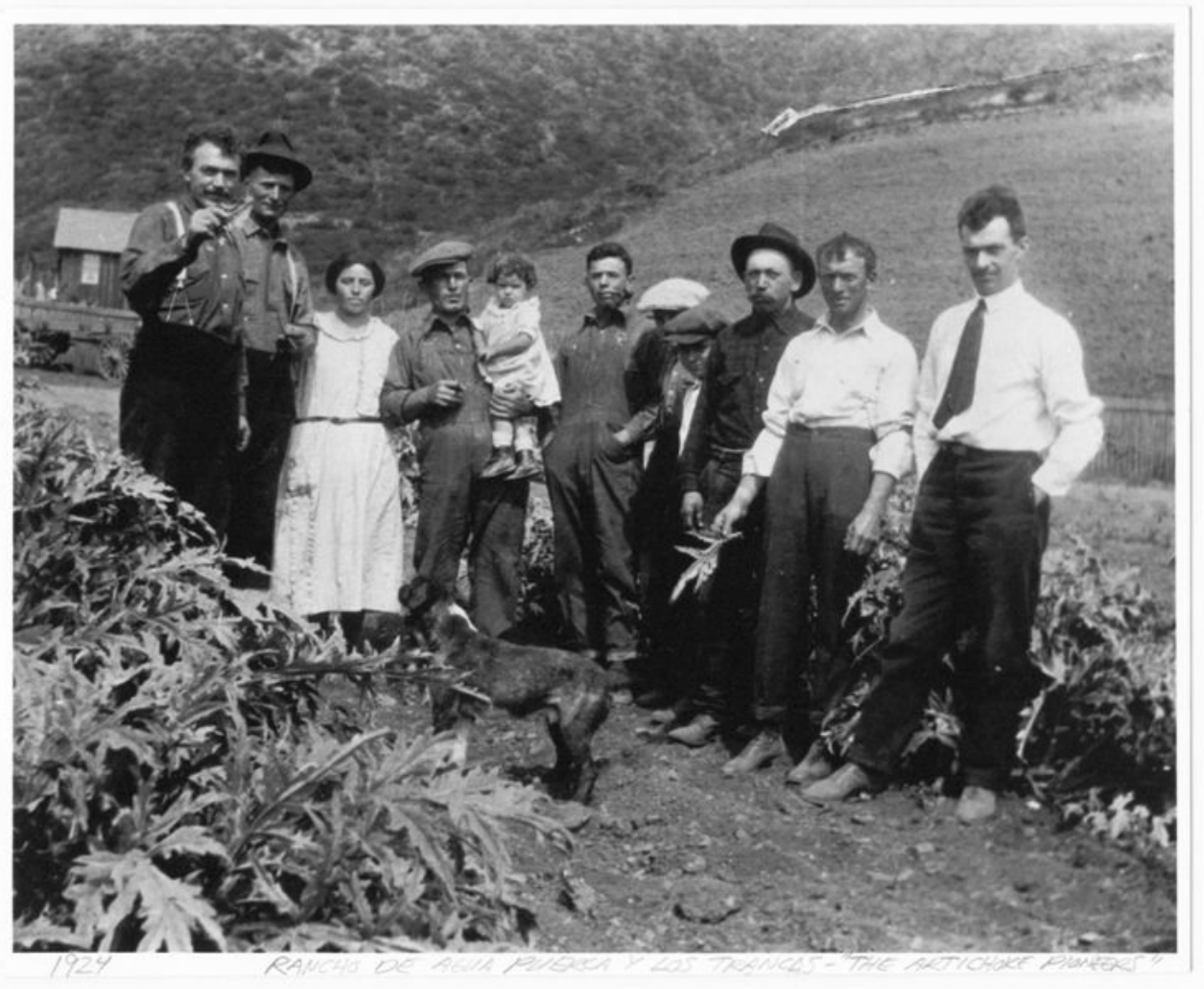

Figure 39: The Artichoke Pioneers, 1924. The Artichoke Pioneers, Siberia, Swanton, 1924. The house and wagon in the background is the Conrado home. From left to right: Mike Conrado, Attilio Venturini, Virginia Pini (a,k.a.Nonni), Celeste Pini (a.k.a Nonno), Marie Pini (1 year old), Ermano Lombardi, John Conrado (father, Mike Conrado), Attilio Conrado (father, Mike Conrado), Jacinto Conrado (brother, Mike Conrado), unidentified man (ranch worker?), unidentified man (ranch worker?). Image courtesy of Marie Pini Stoner. Mike Conrado, Attilio Venturini, Celeste Pini, and Jacinto Conrado were partners in the ranch raising artichokes and Brussels sprouts. Due to the wind and cold the ranch was named Siberia but in Italian was pronounced "SEE-BERRY-AH." Marie Pini Stoner, interview by author, February 1, 2014. 


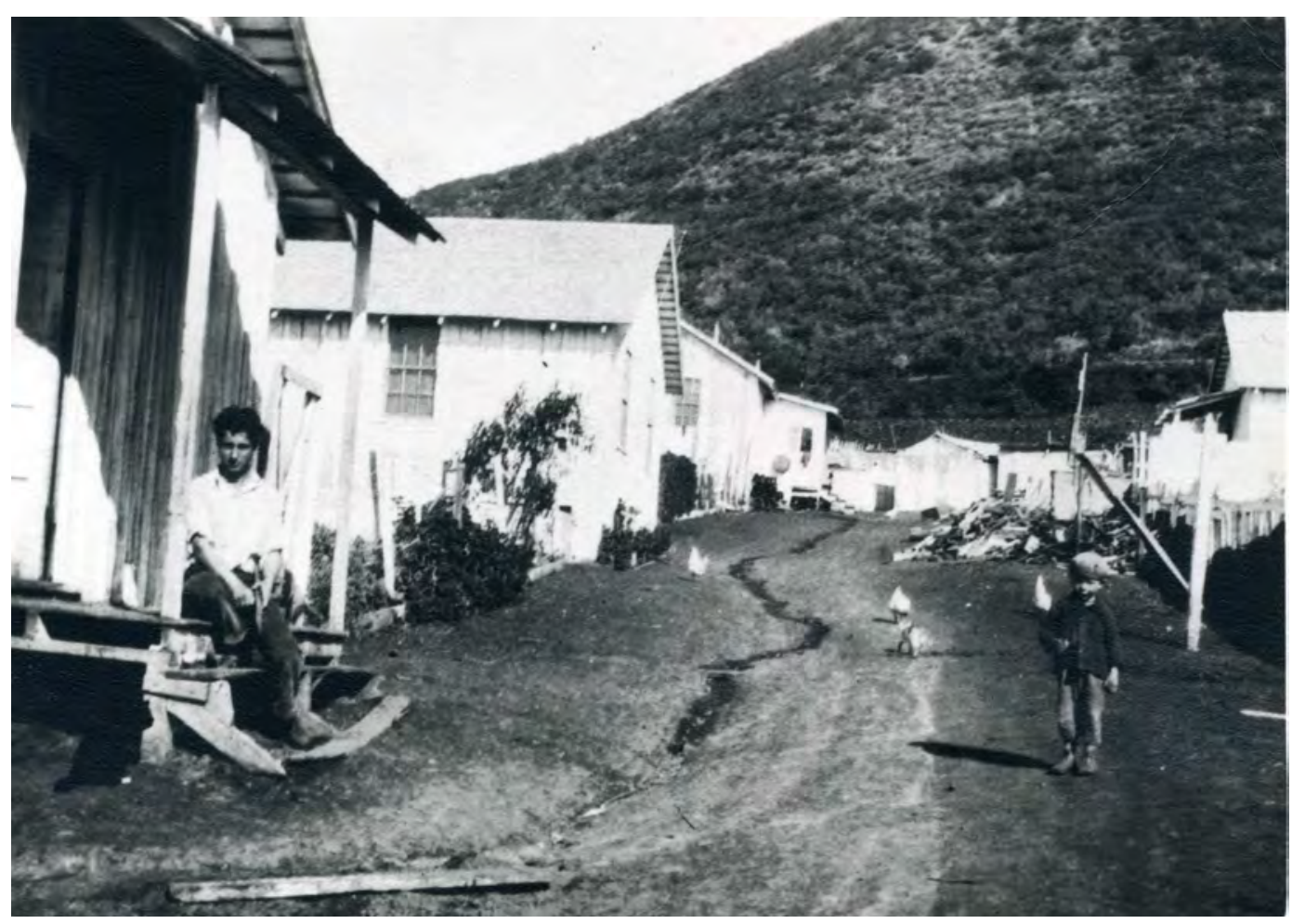

Figure 40: Pini Ranch, 1929. Pini Ranch, Siberia, Swanton, 1929. Buildings clockwise from left: worker home with unidentified individual, Attilio Conrado home, Venturini home, Pini home and garage, and Geno Pini. Courtesy of Marie Pini Stoner. 


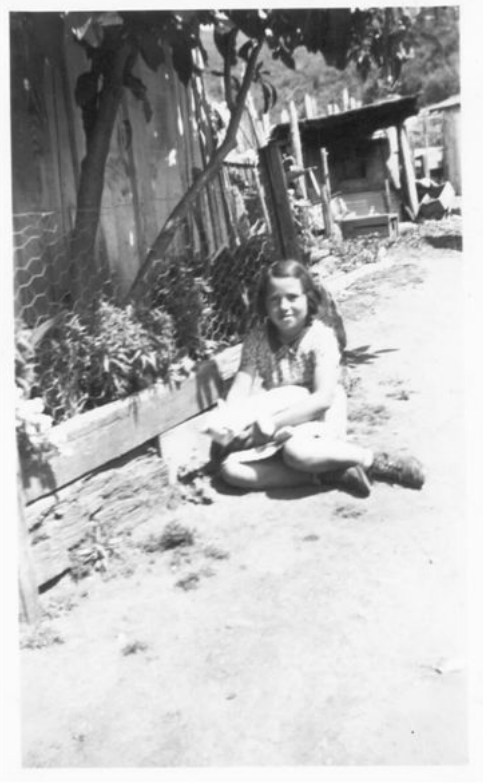

(1)

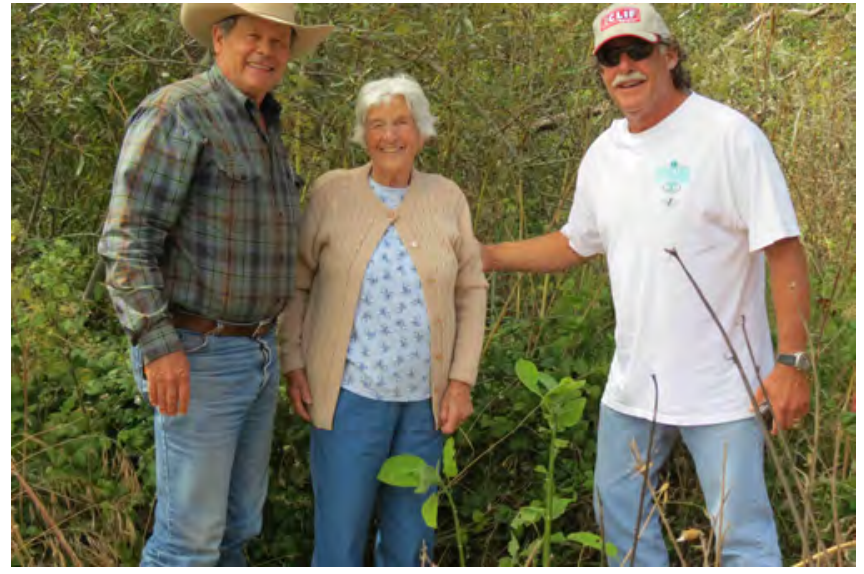

(2)

Figure 41: Trumpet Plant, Siberia, Swanton Pacific Ranch. (1) Pini Ranch, Siberia, Swanton, 1939. Enes (Pini) Mori and cat in front of the family home next to a trumpet plant. Courtesy of Marie Pini Stoner. (2) Pini Ranch, Siberia, Swanton, 31 August 2014. Next to the trumpet plant that previously had been the site of the Pini Family home. From left to right: Gordon Claassen (Swanton Pacific Ranch Livestock Manager), Marie Pini Stoner, and Kim Stoner. From the author's personal collection. 


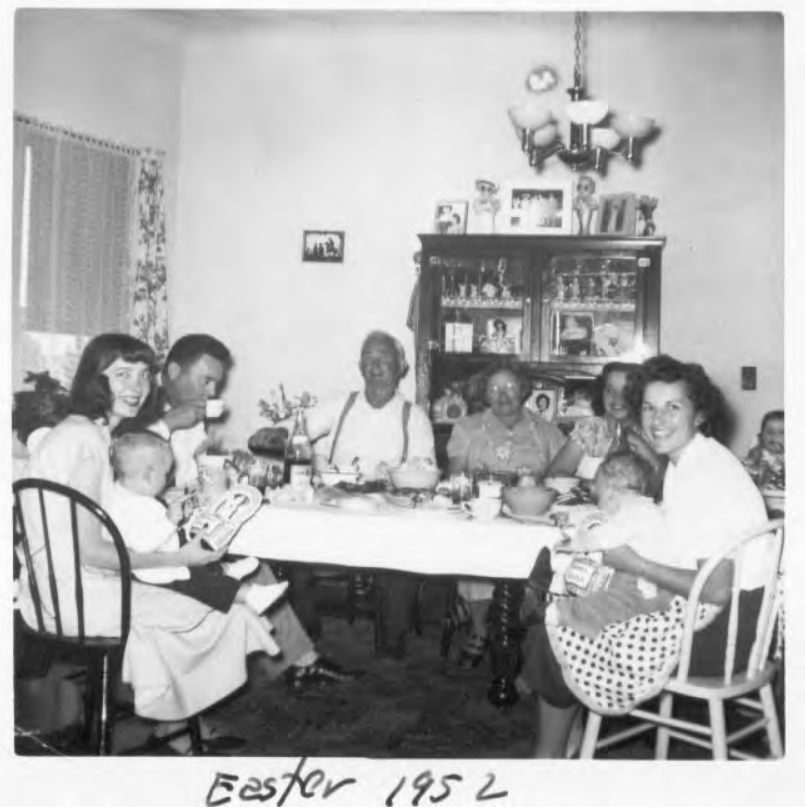

Figure 42: Pini Family Easter, 1952. Santa Cruz, April 13, 1952. From left to right: Geno's wife, Gene Jr., Geno (Marie's brother), Celeste (Marie's father), Virginia (Marie's Mom), unidentified, Marie Pini Stoner, and Kim Stoner. Courtesy of Kim Stoner. 


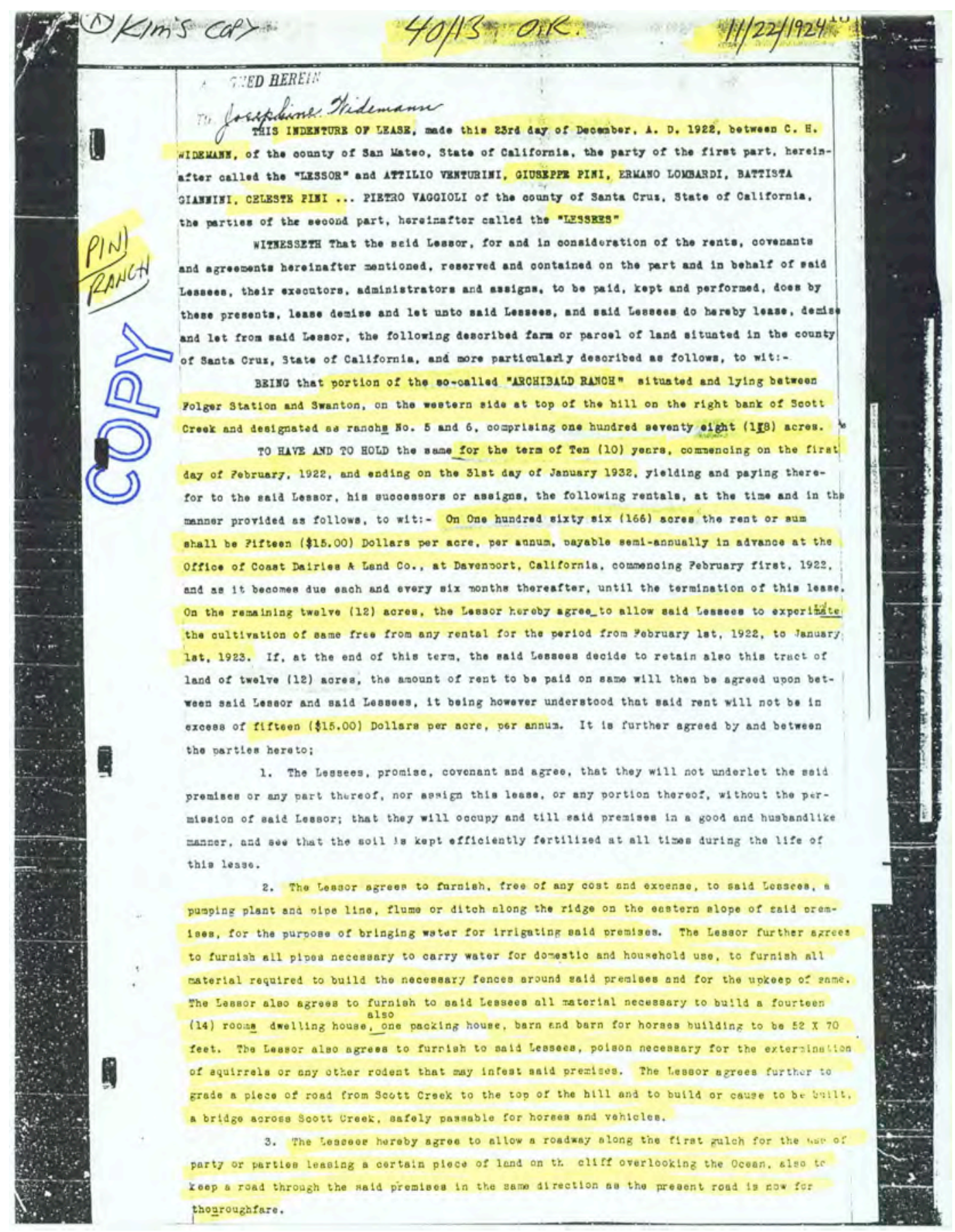

(1) 


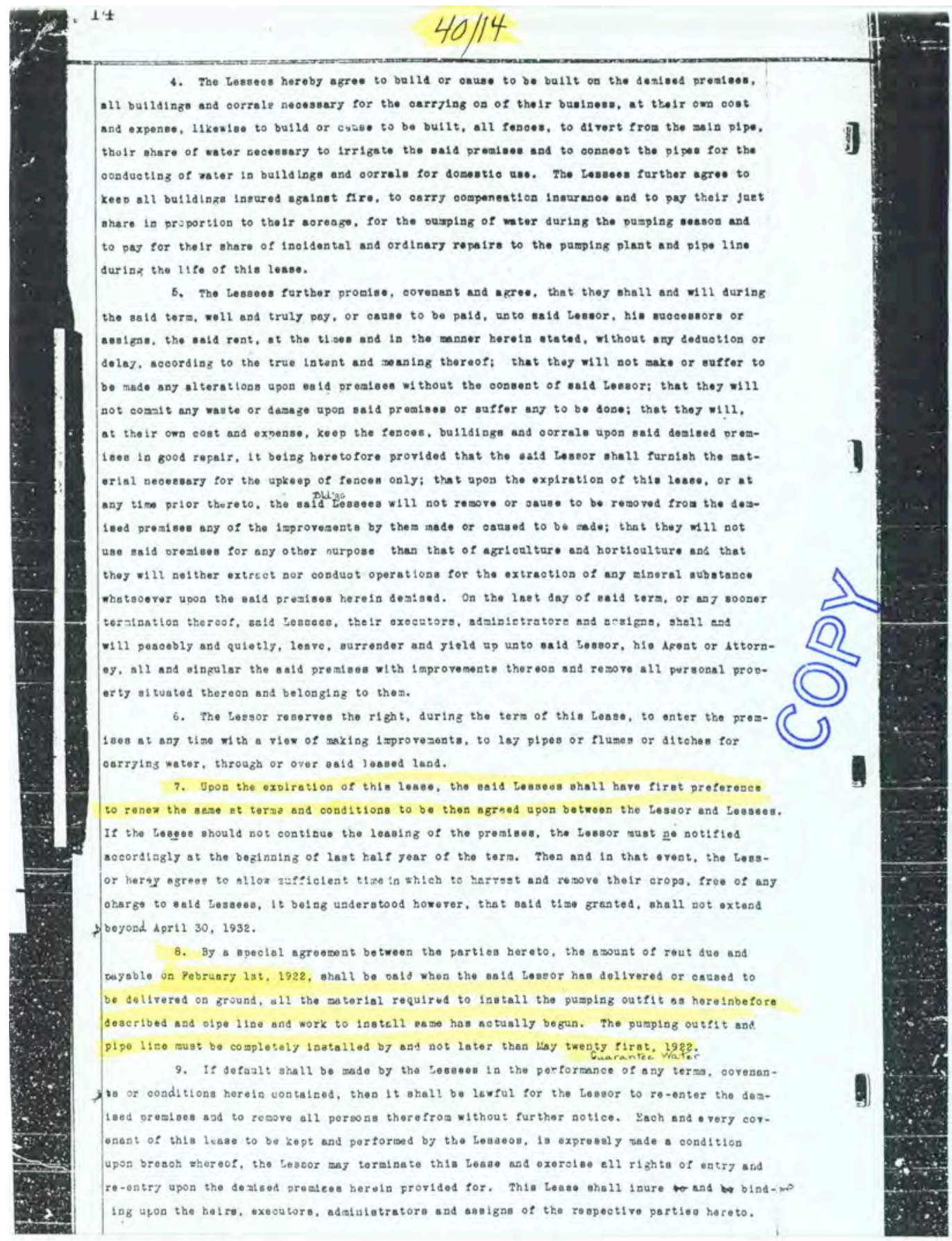

(2) 


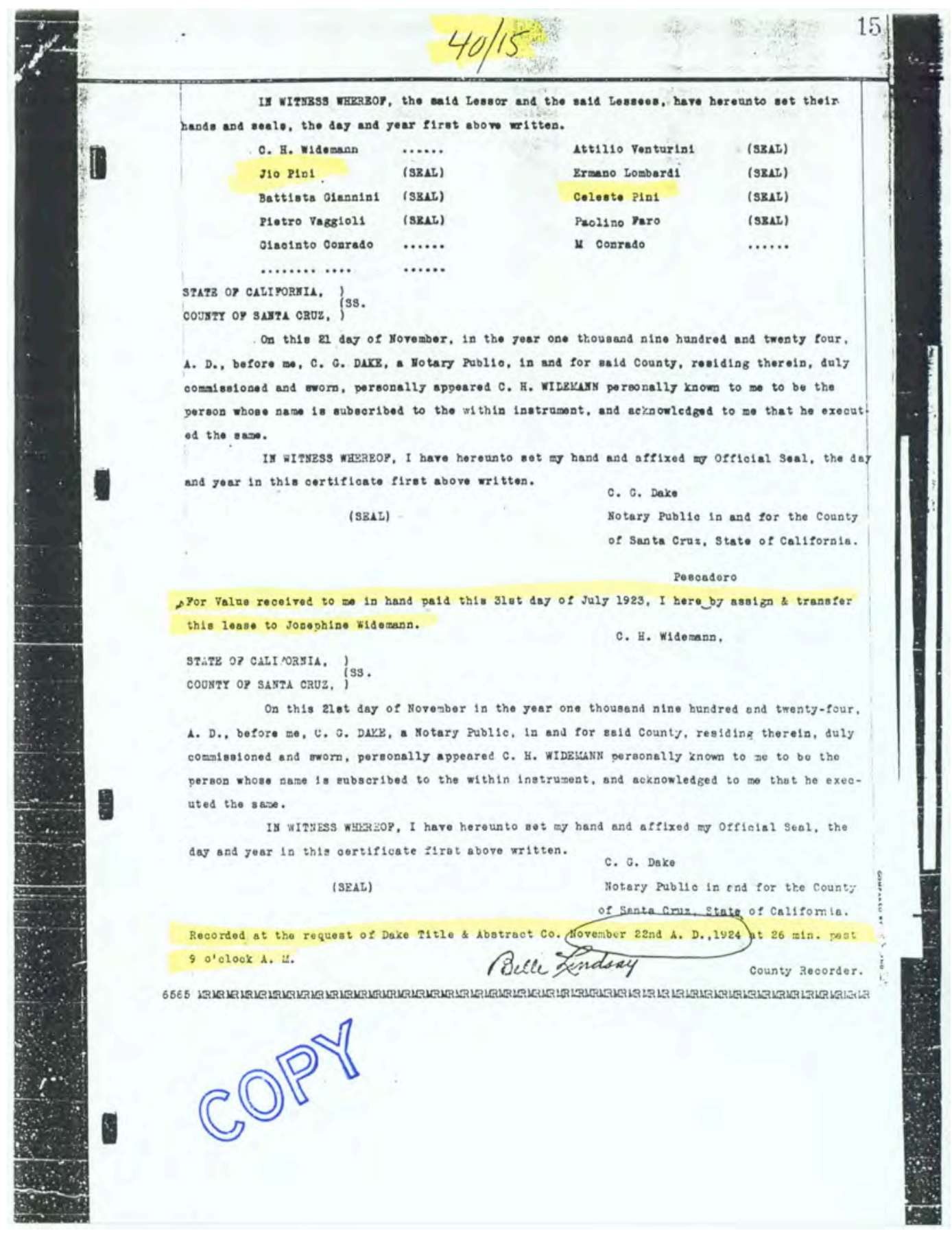

(3)

Figure 43: Pini Ranch Lease. Images 1-3 constitute a copy of the lease filed by the County Recorder, Santa Cruz County between Lessor (C. H. Wideman) and Lessees (Mike Conrado, Attilio Venturini, Giuseppe (Jio) Pini, Ermano Lombardi, Battista Giannini, Celeste Pini, Paolino Faro, Mike Conrado, Pierto Vaggioli, Giacinto Conrado) to rent a portion of "Archibald Ranch" consisting of one hundred seventy-eight acres for ten years from February 1, 1922 to January 31, 1932. Rent was fifteen dollars per acre, per annum, payable semi-annually at the Office of Coast Dairies A Land Company, Davenport, CA. Twelve of those acres were to be rent free for one year for experimental cultivation and later could be rented for the next nine years under the same requirements as the other one hundred sixty-six acres or back out of continuing with the twelve acres. Additional details are available in the lease agreement above. Courtesy of Kim Stoner. 


\section{APPENDIX C: ORCHARD SUPPLY HARDWARE'S INCEPTION}

Orchard Supply Hardware plays an important role in the valley's agricultural history. In 1931, following two years of drought, crop failures and the Great Depression hit the agricultural area surrounding San Jose. Thirty farmers, mostly prune growers, decided to buy their farm supplies as a cooperative, under the leadership of Stanley Smith (AI Smith's father). Each farmer put up $\$ 30$ and Orchard Supply was born. ${ }^{237}$ During the years as a farmer's cooperative, for over a quarter of a century, the co-op was run by General Manager Stanley Smith.

Orchard Supply helped the farmer members to buy and share much needed farm supplies by renting a warehouse on Bassett Street and stockpiling picking pails, sprays and other farming supplies geared toward vegetable or orchard crops. By 1933, the co-op was in need of additional space and moved downtown to 44 Vine Street. In addition to the traditional farming supplies sold by the co-op, the new location added hardware, gardening supplies, and housewares to its stock. Non-farmers were welcomed at this location, and it was known as a place to get practical and helpful advice. Orchard Supply was recognized as a leading hardware store in San Jose, business flourished, and in 1946, a new store was built at 720 West San Carlos Street. A second retail location near downtown San Jose at 449 East Santa Clara St. was added in 1957 to help fill the growing customer demand.

${ }^{237}$ The content for this appendix is an amalgamation, paraphrased or quoted, from the Orchard Supply Company's website, URL: http://www.osh.com/aboutUs and Maggi, 2012, 4, 6, 10. 


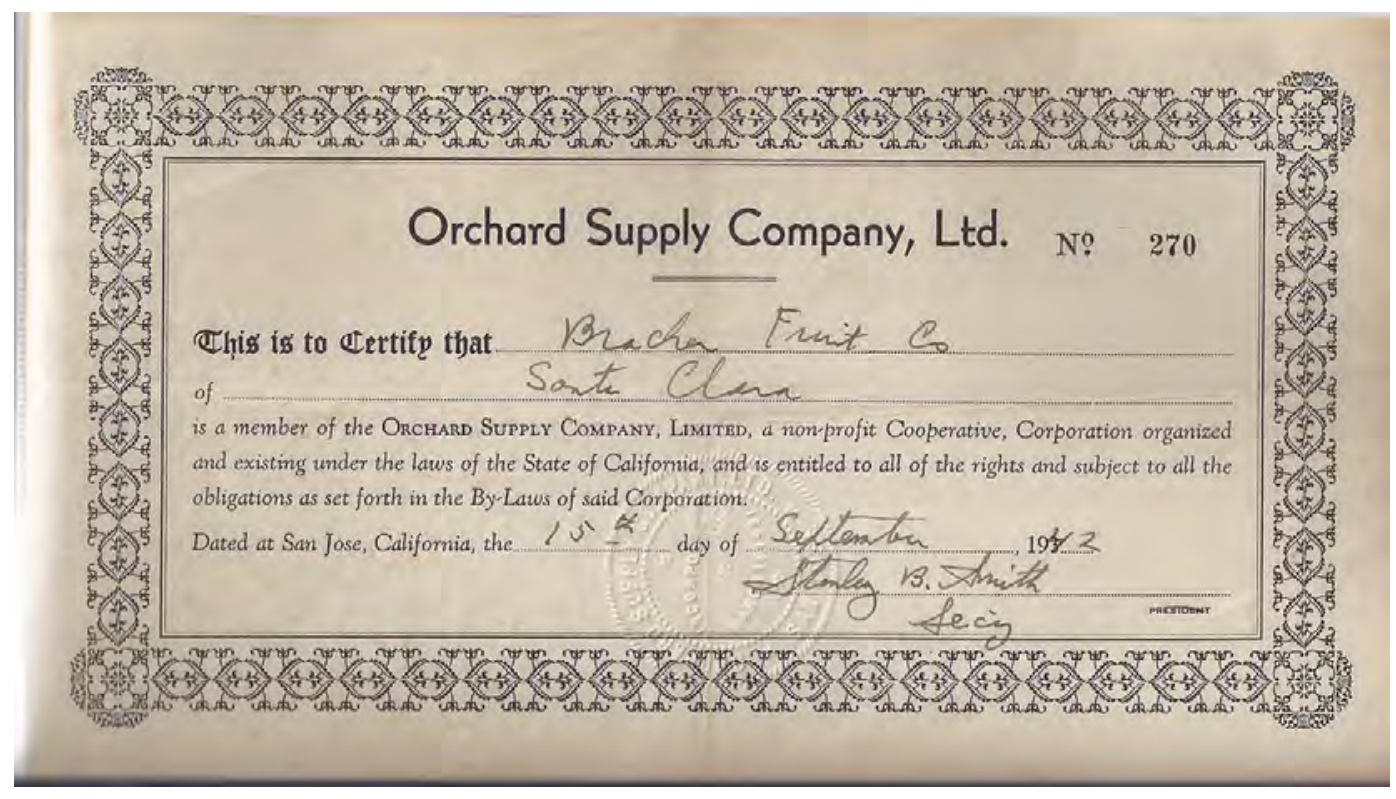

Figure 44: OSH Co-op Certificate. "This is a scan of an original Orchard Supply Hardware (Farmers Coop) membership certificate signed by Stanley Smith, Secretary, and issued to the Bracher Fruit Company of Santa Clara, CA, on September 15th, 1942. This certificate was a replacement for the original one issued in 1931 ; in 1942 the company changed its name from Bracher Brothers Fruit Company." Courtesy Scalhotrod, CC BY-SA 3.0.

In the 1950s, the post-World War II economy in the Santa Clara Valley boomed, and the area saw thousands of new homeowners. Orchards ceased operation as farmers retired and sold their land for suburban development. Nonetheless, Orchard Supply was still a popular shopping place, but it no longer qualified as a cooperative. At about the time of Stanley Smith's retirement, in the late 1950s, a decision was made by the co-op owners to remain in the retail business as Orchard Supply Hardware under the direction of new general manager Kenneth J. Lewis.

In 1962, Al Smith became president of Orchard Supply Hardware. See Chapter 3: Al Smith - Orchard Supply Hardware for information during the interim. In 1979, the company was acquired by W. R. Grace and Company, a chemical and material company based on the east coast. Members were given Grace and Company stock in exchange for their holdings. Shortly after, in 1986, W. R. Grace and Company sold out to Wickes 
Companies, Inc. as part of a multi-retail store deal. Orchard Supply Hardware was acquired from Wickes by Sears Holding Company in 1996. Under Sears, Orchard Supply Hardware branded itself OSH. In 2012, the store became a publically traded company on the NASDAQ under the symbol, "OSH." In September 2013, the company was acquired by home improvement retailer Lowe's, but remains a separate business unit. 
APPENDIX D: SWANTON PACIFIC RAILROAD TIMELINE

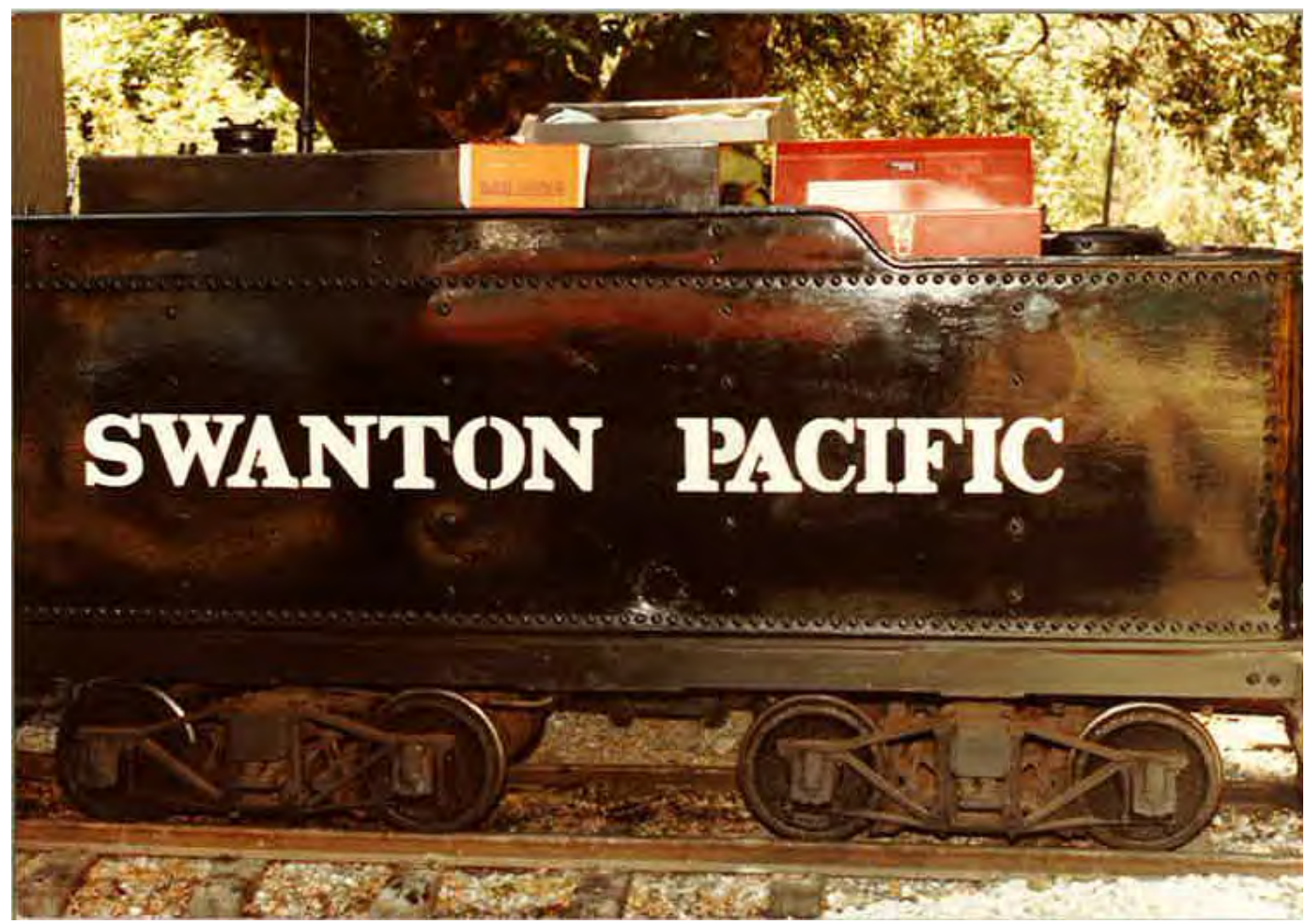

Figure 45: The Swanton Pacific Locomotive Tender. Courtesy Cal Poly Corporation, Swanton Pacific Railroad Society Collection.

The creation of the Swanton Pacific Railroad was a cumulative process over more than a hundred years. The following timeline focuses on the history of the Swanton Pacific Railroad. ${ }^{238}$

1880 - Louis M. MacDermot was born in his family mansion at 7th and Center streets in Oakland, CA.

1898 - Death of Louis M. MacDermot's father, Charles R. MacDermot, a capitalist and millionaire.

1914 - Death of MacDermot's mother.

${ }^{238}$ The content is gleaned from the Swanton Pacific Railroad Historical Society newsletters published from 1995 to 2012, http://sprr.calpoly.edu/newsletters; Frederic Joseph Shaw, Little Railways of the World (Berkeley, CA: Howell-North Press, 1958); Rice and Hovanitz, 1999; Randy Jones, interview by author, June 7, 2015; and Randy Jones email to author, August 13, 2015. Note that the reader needs to review this timeline with a grain of salt as there are various versions, stories, and theories that have been perpetuated over time that support the "facts". 
1913-1914 (Fall) - Construction of all the one-third scale 19-inch gauge steam locomotion rolling stock based on MacDermot's blueprints dated August and September. ${ }^{239}$

1915 - The Overfair Railway Pacifics was created for the movement of people around the Panama-Pacific International Exposition (PPIE), San Francisco, CA.

1916 to 1940 - The machines were stored at the MacDermot family mansion in Oakland, CA. MacDermot's fortune was in decline and his house grounds had deteriorated. There are many stories that MacDermot became withdrawn and private, living alone as a shut in. However, though he was private, he was married with no children, and not in self imposed isolation. ${ }^{240}$

1940 - All of the equipment, four locomotives, and very many of the engines were moved from the MacDermot mansion to the Alameda County Zoological Gardens.

1941 - One locomotive and some cars were used at the Zoological Gardens (now the Oakland Zoo), and it was called the "Mountain Lion Railway or Railroad." Possibly due to personality clashes between MacDermot and Zoological Garden management over the condition of equipment (or possibly money) the business arrangement ended. Some documentation says the railroad was only in use for a few months, while others state that it ran about 4 years until 1944. ${ }^{241}$ MacDermot and his wife had a cottage on the Zoo grounds. It is reported that the cottage was not dirty but filled with locomotive parts, in every place possible, so that the equipment could be in a protective place with a roof. ${ }^{242}$

1941-1942 - Billy Jones, of Los Gatos, California, was interested in narrow gauge, and had his own 18-inch gauge miniature locomotive, but did not have access to all the materials that he needed to build up his railroad. He sought out MacDermot to obtain part of the Overfair. Initially the materials were on "loan" to Billy Jones. Later Billy Jones paid $\$ 10,000$ to get most of the equipment moved down from Oakland to Los Gatos; Jones' wife Geraldine was not thrilled about the expense, but they had enough money to be comfortable. ${ }^{243} \mathrm{He}$ put together one third of a mile of track around his prune orchard. Jones ran the railroad on weekends for children and used it to help charity fundraising. ${ }^{244}$

\footnotetext{
${ }^{239}$ Randy Jones, interview by author, June 7, 2015.

240 Jones learned this information from a conversation with Neil Vodden, one of the three closest friends of Al Smith. Randy Jones, interview by author, June 7, 2015.

${ }^{241}$ The print documentation reviewed by the author states the railroad ran for a few months while Randy Jones says it ran about four years. Randy Jones, interview by author, June 7, 2015. Retracing the history of the Overfair by a student would be a contained topic for a project.

242 Jones learned this information from a conversation with Neil Vodden, who visited MacDermot at the zoo with Billy Jones, and also from Charlie Hoyle, a fellow Southern Pacific employee who was close to both Billy Jones and MacDermot. Randy Jones, interview by author, June 7, 2015.

${ }^{243}$ Randy Jones, interview by author, June 7, 2015.

${ }^{244}$ Billy Jones had four children, two of the boys died in WWII. There are anecdotal stories that point to the running of the train to give happiness to other children even though two of his own had died.
} 
1943 - Subsequently MacDermot participated in the opening of Billy Jones' Wildcat Railroad. ${ }^{245}$ The Wildcat Railroad used Overfair passenger cars, with trucks modified for 18-inch gauge.

1948 - MacDermot passed away, and the remaining rail equipment was bought by Billy Jones for $\$ 5,200$ from the MacDermot estate. Another version states that Billy Jones had advanced money to MacDermot. When MacDermot died in debt, Jones was still owed the money, and the executor of the estate claimed that cash debt needed to be taken care of first. However, the executor said that there was nothing of value to sell to bring in cash funds. So he suggested that maybe Jones would take the train items in lieu of cash. Jones first said, "maybe I will consider it," but he actually wanted to make sure he got the equipment to keep it from being scrapped. There was no monetary gain and the debt may actually have been $\$ 7,000 .^{246}$

1954 - Correspondence between Jones and Walt Disney hinted at the sale of the Overfair to Disney for his "different style" of family theme park, but plans fell through.

1960 - Three engines were sold by Billy Jones to a California corporate firm but were never used. They were sold because Jones could not run them on his property; they tried but they derailed. He hoped they would see operation one day. During this year the Overfair Corporation was formed by F. Shaw, Q. Jervis, and S. Franklin. One engine was operated at the Orange County fairgrounds, only during fairs and only for a few years because it became inoperable. The boiler was significantly deteriorated at the fair or in storage. ${ }^{247}$

1968 (January) - Billy Jones died and the Overfair Railway was put up for sale.

1969 - Robert Maxfield, a Piedmont (Oakland) real estate appraiser, bought the \#1912 and \#1913 engines, car parts, three passenger cars, ${ }^{248}$ freight, and one of the flat cars that was intact. These engines and cars moved from the Billy Jones Ranch to Oakland.

\footnotetext{
${ }^{245}$ Most people think that the name was in reference to Los Gatos (i.e. the cats) but really it was because someone came out to the railroad saying "this is a wildcat operation," in reference to the Wildcat Oilfielders, where people will do anything and work on a shoestring budget to make something a success. Randy Jones, interview by author, June 7, 2015.

${ }^{246}$ Jones learned this information from a conversation with Neil Vodeen, who visited MacDermot at the Zoo with Billy Jones. Randy Jones, interview by author, June 7, 2015.

${ }^{247}$ Randy Jones's and some of the other Swanton Pacific Ranch Society members speculate that the deterioration may actually have been due to the fact that they were not maintaining the engine appropriately. They could only speak to the condition when it arrived at Swanton, and speculate from there. Randy Jones email to author, August 13, 2015.

${ }^{248}$ This may not be correct. Maxfield may have had three passenger cars built at/for Calistoga. Randy Jones, email to author, August 13, 2015.
} 
1970 - It appears from photos taken by Maxfield and Steven Rives that the engines were overhauled in Oakland in 1974 and then moved to Redwood Valley Shops to fix the materials; the engines were stored there by the shop manager, Eric Thomsen.

1975 - Maxfield was looking for a place to set up the railway to help with tourism in the area. However, he confessed to the biggest mistake: when looking for property, he fell in love with property that was off the beaten path, and people could not be convinced to stop and visit. The operation of the \#1913 engine ran near/parallel to the runways at Calistoga Airport, Napa County, as part of a new railroad, named the Calistoga Steam Railroad.

1977 - After a few years of less than successful operation, Maxfield put his equipment up for sale. There is some disagreement about the date, that it might not have been 1977 but actually 1979 when it was put up for sale.

1978 - Discussions began with Al Smith to purchase a share in the railroad at Calistoga so Smith would be able to get away from the city and enjoy the train without the effort of running the operation.

1979 - Maxfield was desperate to sell the railroad equipment. Smith and Maxfield had a number of phone calls over time negotiating a reasonable price for the Calistoga equipment with the turntable (which Randy Jones built in 1977 in Calistoga). ${ }^{249}$ In the summer, Maxfield lowered the price but Smith said he would not spend that much on something just for pleasure. Maxfield asked Smith what a reasonable price was hypothetically, and he responded that he couldn't see spending more than $\$ 100 \mathrm{~K}$ just for fun; Maxfield was absolutely crestfallen. A month later Maxfield called Smith and said "I've agreed to take you up on your 'offer'." Smith said something to the effect of, "Whoa, wait a minute, I never actually offered to buy anything." In the end, they made the deal and Maxfield agreed to sell at $\$ 100 \mathrm{~K} .{ }^{250}$ Smith bought everything but a few buildings on the property including the ties, tools, rail, etc. and construction moved forward on the Swanton Pacific Railroad. ${ }^{251}$

\footnotetext{
${ }^{249}$ Randy Jones, a long time locomotive engineer and SPRS member, has been involved and connected to the railroad for a long time. In 1949, Randy Jones was one year old when his parents took him along on the Wildcat Railroad. When he was five he has pictures of himself in a full engineering outfit that his aunt from back east had sent him. Billy Jones was his hero. Billy would see Randy and other kids looking through the windows of the sheds that held the \#1913 (which was painted blue/the sheet metal was painted blue; but the heavy metal was all painted black) and \#1912. Billy would shoo all the kids away but would seek out Randy later and allow him to go in the sheds. Randy says he would just sit in the \#1912 and dream. This is yet another connection between the Overfair and Swanton Pacific Railroad. Randy Jones, interview by author, June 7, 2015.

${ }^{250}$ Later Smith said to Randy Jones that he was taken aback; Smith said he thought that Maxfield and he were "just talking" not that an offer to buy was made. Smith went on to say something to the effect of, "if I was willing to pay $\$ 100 \mathrm{~K}$ for property [at Swanton] to deal with an easement problem then spending $\$ 100 \mathrm{~K}$ to buy something for enjoyment was not unreasonable.' Randy Jones, interview by author, June 7, 2015. ${ }^{251}$ An interesting note is that in the late 1980s-early 1990s Neil Vodden began to see if there was any 19 inch gauge available, beyond what SPRS already had. Though it would have been possible to use 18-inch
} 
1983 - As part of the estate auction of Quentin Jervis by the Public Administrator of Los Angeles County, Smith bought the Overfair engines \#1914 and \#1915 for $\$ 5,500$ and $\$ 2,500$ respectively. Neil Vodden paid $\$ 8,500$ for the switcher $\# 1500$, which he later sold to the Billy Jones Wildcat Railroad Corporation.

1991 - Smith gave engine \#1915 to the California State Railway Museum, and it was put on display in the Museum's lobby with the \#1914's cab. The \#1915's cab had never been built.

1992 - The Swanton Pacific Railroad Society (SPRS) had its first formal meeting in January 1992 and its charter is to "preserve, protect and expand the Swanton Pacific Railroad" as a "living, operational memorial to Smith."252

1993 (December) - Smith passed away.

1994 - Ownership of Swanton Pacific Ranch and Railroad passed to the Cal Poly Foundation. Smith's Orchard Supply caboose, his former office, was moved from Los Gatos to Swanton Pacific Ranch.

1995 - Engine \#1500 was purchased by the Swanton Pacific Railroad from the Billy Jones Wildcat Railroad Corporation, and it was moved to the Swanton Pacific Ranch.

gauge. But during his search he learned that someone in Keystone, Pennsylvania had bought a 19-inch gauge train and three passenger cars. Smith called a friend and took a plane to go back east and investigate. Indeed it was 19-inch gauge. Smith bought it but it was a mystery how the 19-inch gauge was made there, plus there were some truck/wheel, etc. parts. When Randy Jones was unloading the "Keystone equipment" he saw that it actually was an Overfair truck. The previous owners had tried a new way to manufacture a new brake. There is speculation that in the 1960s, the people back east must have bought or loaned the Overfair truck from Billy Jones or Jervis. Randy Jones, interview by author, June 7, 2015.

${ }^{252}$ Rice and Hovanitz, 1999, 23. 


\section{APPENDIX E: SCHOOL OF AGRICULTURE WORK DAY 1991 AGENDA}

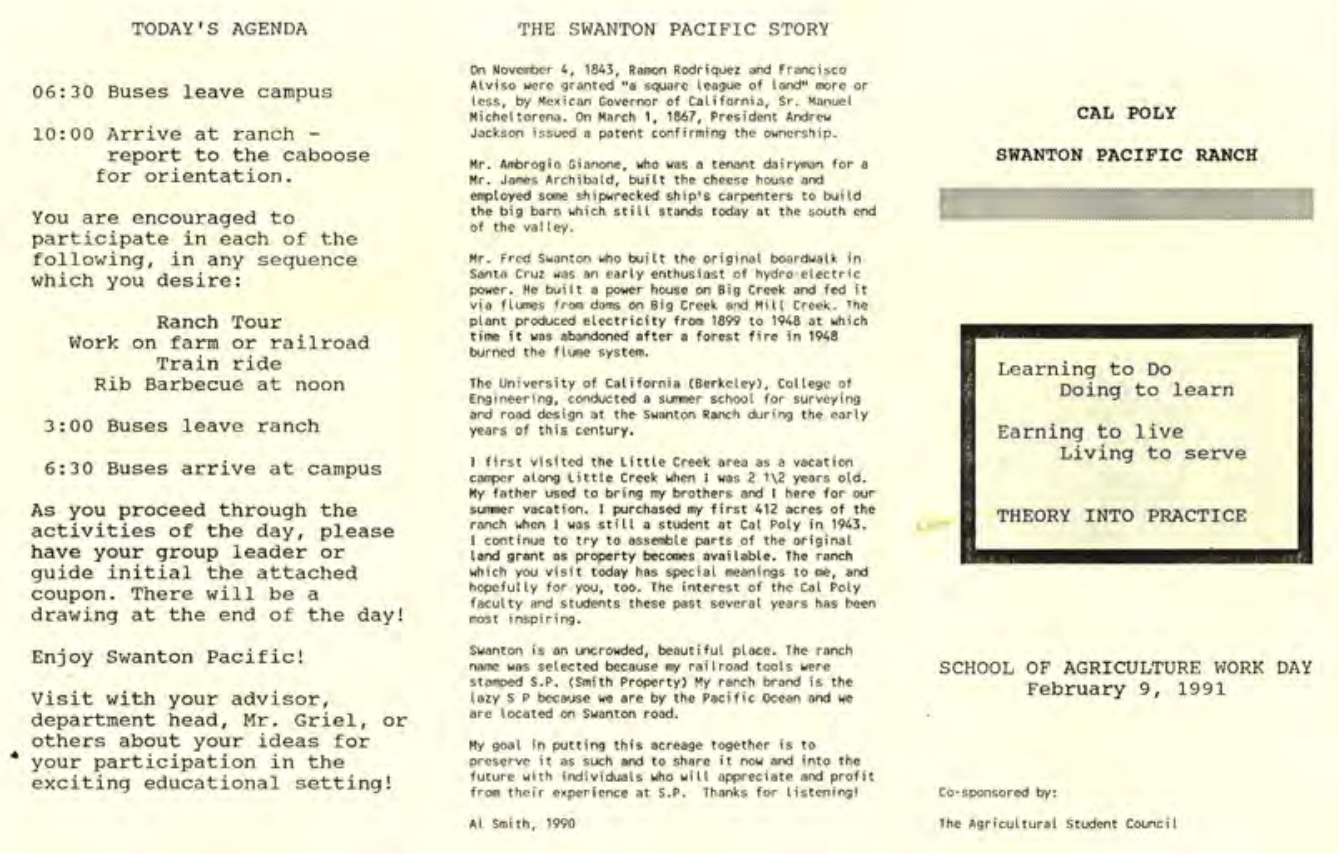


Welcome to swanton Pacific!

Your participation in the educational, work experience, and recreational activities Ranch is sure to be one of the Cal Poly.

Mr. Al Smith, owner, has a strong desire to see that Cal Poly have many of the learn-by-doing opportunities which he enjoyed as a student in crop science in the early 1940 's. Your visit to the ranch, and your use of the ranch to enrich your

university life, provides real pleasure to Al Snith as he assists you in preparation for your career.

Mr. Smith and Cal Poly are so convinced of the value of this ranch to support the

educational programs of the

university, that Mr. Smith has

agreed to donate the land to cal poly. Your participation the significance of this special place.
Cal poly

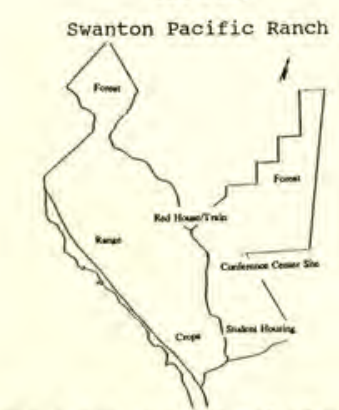

The 3,200 acre Cal poly swanton Pacific Ranch consists of fores and natural areas, range land and crop land. The ranch has more than 3 miles of ocean frontage along the pacific Ocean.

A $1 / 3$ scale steam railroad perates on the ranch. Mr. Smith has expressed an interest in turibit one of the we plan

engines at the 1991 Rail pair in Sacramento in early May.

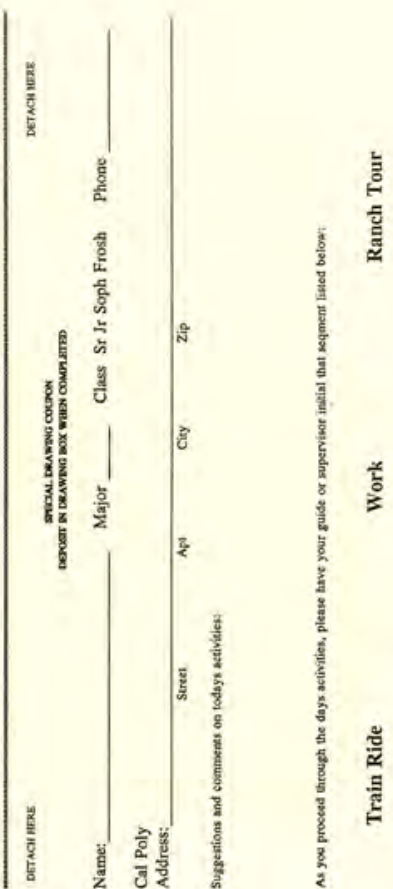


APPENDIX F: STUDENT USE OF SWANTON PACIFIC RANCH 1997-98 COLLEGE YEAR SUMMARY

Prepared 14 July 1998 by Wally Mark

Over the past year the use of Swanton Pacific Ranch for students from Cal Poly and for students from various schools around the state has been very intense. There were a total of 18 class field trips or Equity Leadership Program activities scheduled at the ranch. Nearly all the classes occur on weekends, so this resulted in usage on 13 weekends during the year. Student days on the ranch associated with these activities totaled 1,208 days.

Over the past five terms, including summers 97 and 98, there have been 18 interns at the ranch. Heaviest usage remains the summer, when students are better able to accommodate an internship in their schedule without delaying their graduation. The development of the intern position descriptions, the information board in Building 10, past intern talks in classes, and a new faculty member in Animal Science have all had a significant impact in generating increased interest in Swanton internships.

There have been 7 senior projects or special problems and one master's degree thesis completed. Three more senior projects and one thesis are currently in process. There have been 9 work parties of students come up to the ranch to assist in specific tasks, mostly having to do with the livestock programs. The addition of Jonathon Beckett to the Animal Science Department faculty bas been very important in increasing student interaction at the ranch. These include fence crews, students to work the cattle, and the 
Cal Poly Logging Team. The logging team is scheduled to host the Association of Western Forestry Clubs annual conclave at the ranch next April.

Campus groups and other school users, such as FFA leadership groups have used the ranch on 11 more occasions. These activities increase awareness of the ranch and of agriculture and natural resources in general. The total for the year from July 1 , 1997 to June 30,1998 is 38 different groups or activities of an educational nature at the ranch and 18 internships. These 38 events have resulted in a total of 1,786 student use days. These are in addition to the internship, senior project, special problems and master's thesis time on the ranch. 


\section{の $P$ \\ INTERNSHIP INFORMATION PACKET \\ SWANTON PACIFIC RANCH \\ Davenport, California}

Swanton Pacific Ranch consists of approximately 3,000 acres north of Davenport along Highway One and about 660 acres along Valencia Creek south of Santa Cruz. These properties were donated to the Cal Poly Foundation as part of the estate of Al Smith. Al Smith was a Cal Poly graduate and the founder of Orchard Supply Hardware. The conditions as stated for use of the ranch property in the living trust document are: "....that it (Swanton Pacific Ranch) be maintained as a working ranch for instructional purposes and that it not be sold or transferred to other than another entity exempt from taxes, which will maintain its use exclusively for agricultural, recreational or educational purposes."

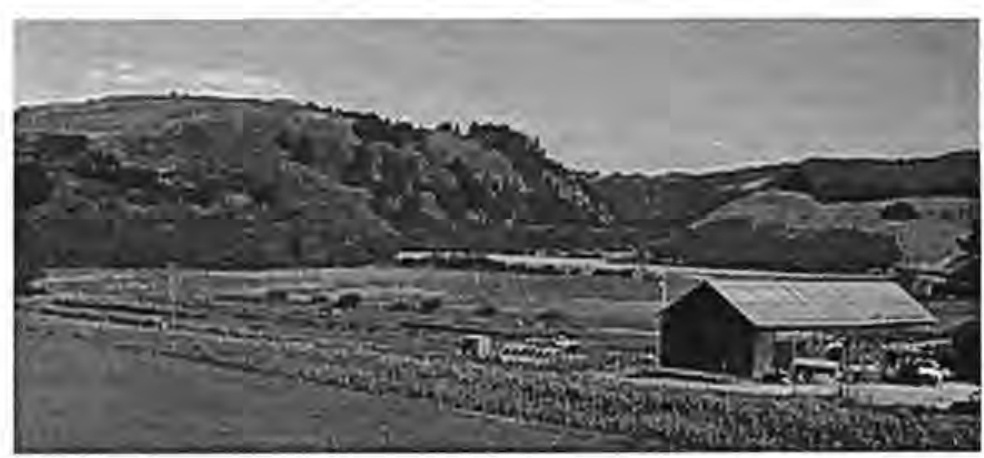

Swanton Pacific Ranch is comprised of a diverse landscape overlooking the Pacific Ocean, 15 miles north of Santa Cruz. Scott's Creek, a year round stream reaching to the ocean, bisects the property. The elevation ranges from sea level at the estuary to around 1,200 feet on the ridge north of Little Creek. The land use results in four logical divisions; cropland, forest, rangeland, and riparian; however the ranch is managed under holistic management. The current cropland acreage is approximately 115 acres, all of it in organic production of vegetables and oat hay. Forested lands are managed as commercial forests and comprise around 1000 acres at Swanton and the entire 660 acres of Valencia Creek. These forests are predominately second growth redwood-Douglas-fir forests resulting from logging from 1909 through 1921. Some of the stands have had logging continuing through the 1970's. Rangeland accounts for roughly 1,900 acres, located primarily on the coastal side of Scott's Creek. Livestock programs include stockers, cow-calf, and meat goats. Riparian corridors exist along Scott's Creek, Mill Creek, Little Creek, Archibald Creek, Queseria Creek, and some smaller unnamed drainages. These provide critical habitat to both the endangered Coho salmon and the threatened steelhead trout as do the wetlands at the mouth of Scott's Creek. 


\section{c) P}

INTERNGHIP INFORMATION

SWANTON PACAFIC RANCB

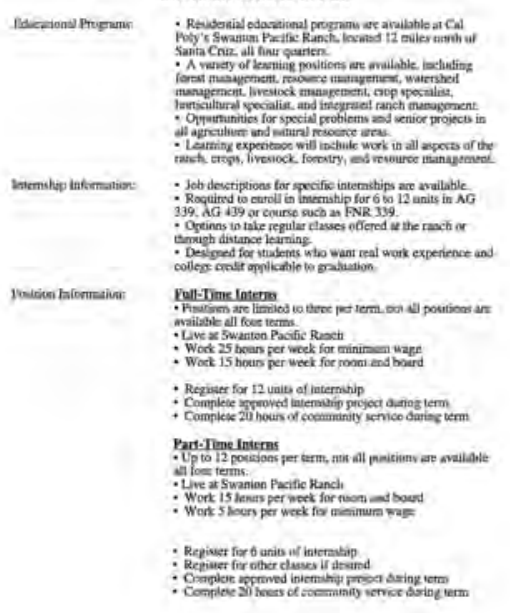

\section{U P}

Swanton Pacilic Ranch literenshipp

RESOURCE MANAGEMENT

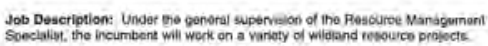

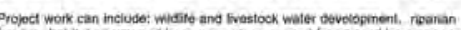

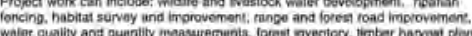

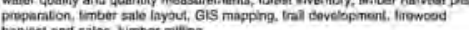
harvest and solos, wimber miting

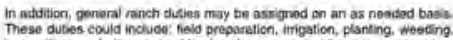

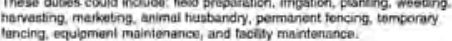

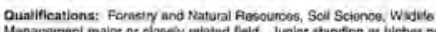

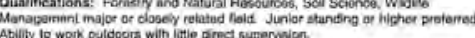

Aequirements: Ability to communicate aftoctvelv and to ges arong with ofhers

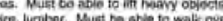

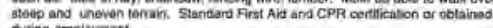

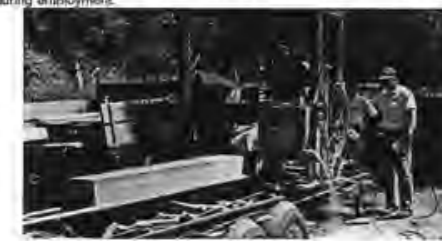

\section{の P}

Swanton Pacific Ranch Internathip LIVESTOCK MANAGEMENT

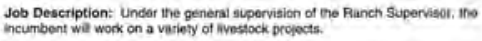

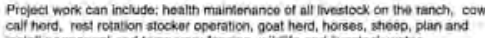
water

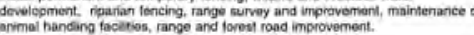
In adation, general ranch dutios may bo assigned on an as noedod batis.

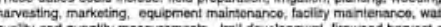
d havest and

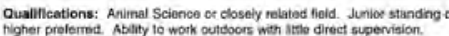

Requirements: Abity to communicate efflectivety and to got along with othery

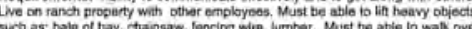

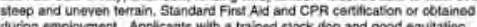

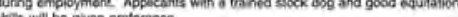

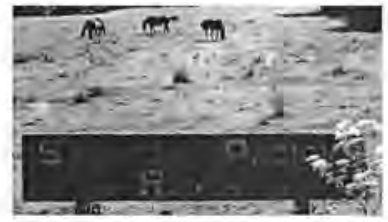

\section{O P}

INTERNSHT APPLICATION INFORMATION SWANTON PACAFC RANCH

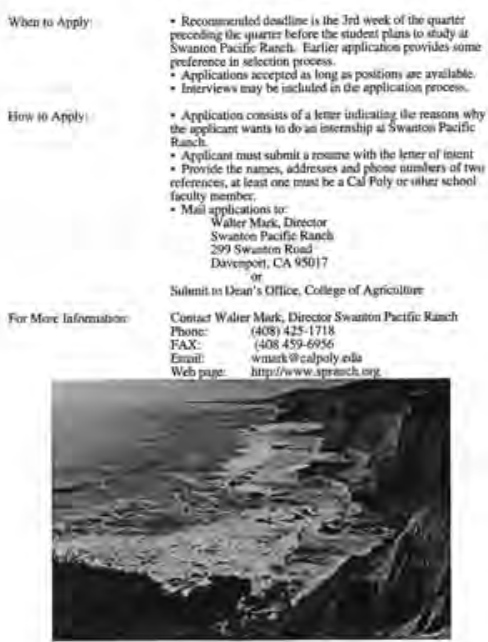




\section{( P}

Swarton Pacific Ranch lntermship

CROP SPECIALIST

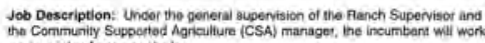

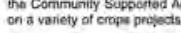

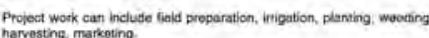

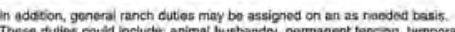

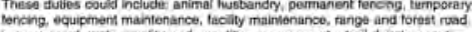

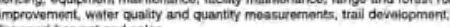
trewood havnest and sales:

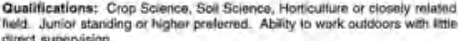
diret supenisition.

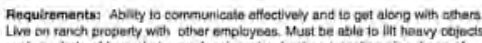

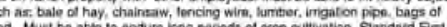

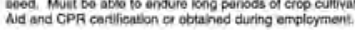

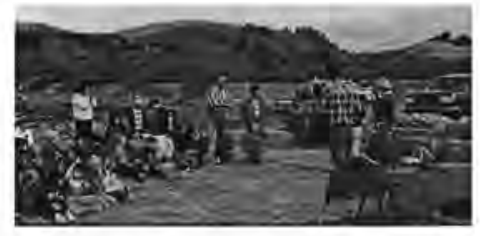

\section{の P}

Swantur Pacticic Hanch Intenstiig

FOREST MANAGEMENT
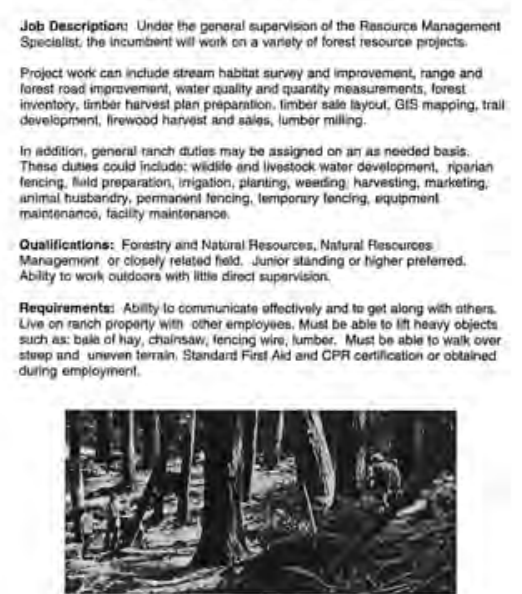


\section{の P}

Swantan Pacific Ranch tntersashe

INTEGRATED RANCH MANAGEMENT

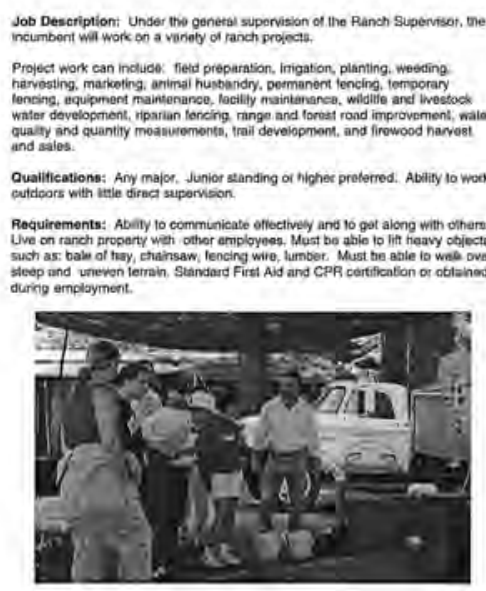

\section{の P}

Swanion Pacific Ranch Internstip

WATERSHED MANAGEMENT

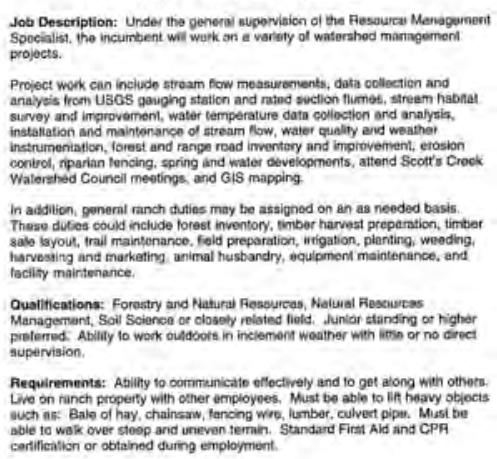

\section{の P}

Swarton Pacific Ranct Internstip

HORTICULTURAL SPECIALIST

Jot Description: Uneer the generes supervision of tre Ranch Supenisor, the

Projoct werk can include lardiscaping development and maintenance, Farmers

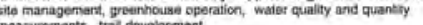
moasurementr, tral dovelopprient

In addition, general ranch dubles may be assigned on an as nesded basis

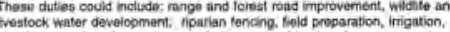

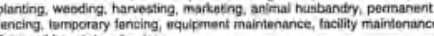
firewood harvest and sails

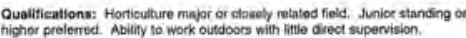

Pequirements: Abitity to consmunicate aftectively and to get along with athers

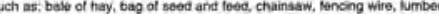
Must be able to walk over stoop and uneven tertain. Standard First Ald an

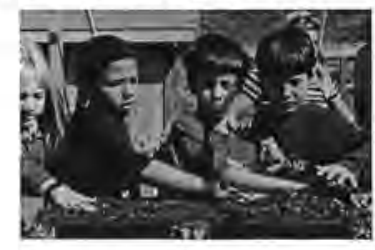


APPENDIX H: THE CAL BARN: 100 YEARS OF UNIVERSITIES IN THE COASTAL REGION OF NORTHERN SANTA CRUZ COUNTY

Prepared by Bob Parkinson, Swanton Pacific Railroad Society Information retrieved from the Bancroft Library Archives, University of California at Berkeley

University activities and establishments have been located in the Santa CruzSwanton area for almost two-thirds of the past 100 years. The University of California at Berkley conducted a Summer School of Surveying during May and June in the Davenport and the Swanton areas from 1904 to 1924. In 1956, the rapidly expanding University of California established its ninth campus on the Cowell Ranch just north of the City of Santa Cruz. With Al Smith's death in December 1993, his Swanton Pacific Ranch and Railroad passed by bequeath to his alma mater, "Cal Poly", the California Polytechnic State University at San Luis Obispo. Thus, this region has a long, rich heritage of higher educational endeavors.

Of special interest to Cal Poly friends is the Summer School of Surveying conducted by the Department of Civil Engineering, University of California at Berkeley. From 1904 to 1908, the Summer School of Surveying was located along the Liddell Creek Canyon just south of Davenport. Then, it moved to the location at the junction of Little Creek with Scott Creek, the present site of the Swanton Pacific Railroad yard, where it remained for fifteen years from May 1909 through June 1924. The "Cal Barn" was the dining and assembly hall for the surveying students, who camped in tents pitched in the large meadow where the College Park railroad station is now located. The students were from the Freshman Class Introductory Surveying and the Junior Class Advanced Surveying. They traveled by the Southern Pacific Railroad from Berkeley to San Jose, 
then by the [Southern Pacific's] Coast branch to Santa Cruz, and, lastly, by the Ocean

Shore Railroad from Santa Cruz to Swanton.

"The Arrival. After a rough trip in the only coach of the jerkwater line from Santa Cruz, the monotony of which was relieved by songs, games, and rollin' 'em, we arrived at our summer residence, Swanton, a town which is honored by being the terminus of the Ocean Shore Railroad and the site of Camp California. The camp itself is situated in a delightful little valley among 'the murmuring pines and hemlocks' (and poison oak), well sheltered from the untiring effects of Boreas [the God of Winds], and, ye gods, here he reigns supreme."

From the beginning of their stay in 1908 at the Swanton site, Professor Charles

Derleth, Jr., the Head of the Civil Engineering Department, repeatedly urged the

University's President and its Regents to buy the land at Swanton. After the expiration of

the original ten-year lease, however, only a five-year extension was obtained. Finally, in

1922, Derleth wrote, "encroachments of agricultural interests at Swanton make it

probable that we must soon vacate."

\section{Excerpts from Derleth's annual reports to University Presidents:}

Derleth to Wheeler, 30 June 1912

"Our buildings have been improved and enlarged at Berkeley and at [the Summer School of Surveying]...Other apparatus never used at Berkeley is now permanently at Swanton, Santa Cruz County, thus avoiding heavy yearly freight shipments. This change has been made possible because of the first class buildings erected at the summer camp headquarters during the past two years. Five buildings, a water works with filtration plant, and other developments have been contracted at the junction of Little and Scott Creeks near the ocean coast, twenty miles north from Santa Cruz. The value to us of these properties in place exceeds $\$ 8,000$. We now have at least a value of $\$ 10,000$ in buildings [and] equipment... at our Summer School of Surveying near Swanton. The lease expires in 1919. In the next seven years we expect to spend more money in camp construction, also we shall have established a permanent triangulation system. We urge therefore that the Regents consider immediately either an extension of the lease, or better, the purchase of the property. The ranch could be sublet upon conditions that the lessee acts as our caretaker and allows us the privilege of trespass during the months of May-June-July of each year."

\section{Derleth to Wheeler, 21 August 1913}

"The University should purchase not merely the headquarters' property of 80 acres, but also the surrounding ranches so that we need not trespass. Such ranches could be sublet to a person who acts as caretaker. We urge this purchase as a most important present need." 


\section{Derleth to Campbell, 1 July 1924}

"Due to foot and mouth disease, the Summer School of Surveying has been conducted upon the Berkeley Campus. Our lease of the Swanton site lapses this year, where the school has been held since 1909. Through the courtesy of the Marin Municipal Water District we are establishing a new campsite near Fairfax...So ended the UC Berkeley Summer School of Surveying at Swanton."

\section{Student accounts of their experiences at Swanton found in The Blue \& Gold yearbooks:}

\section{Blue \& Gold, 1916:}

"Last summer the camp was situated in the valley of Swanton, about fifteen miles north of Santa Cruz. It lies in a little creek basin, thickly covered with redwoods and sheltered by high hills from ocean breezes. The students live in tents and eat their meals in a permanent wooden building, the headquarters of the commissar department [the "Cal Barn"]...The work covered by the Freshman in the course consists in elementary problems in leveling, triangulation, topography, and solar meridian...."

\section{Blue \& Gold, 1918:}

"For the Junior Civil Engineers, the camp is a dismal dredge. There is nothing at Swanton that they had not already seen during the Freshman year. They had already climbed all the peaks, carried transits over all the trails and had endured all the varieties of poison oak that thrive in the vicinity of the camp. But for the Freshmen, new vistas appear every day. They are treated, many of them for the first time, with the trials of camp life, with bedclothes that won't stay put, straw mattresses that develop great holes and mounds with each night's sleep, lunches that defy the most ravishing of appetites, and hills that grow steeper and higher even as one climbs them. But these, the new men soon become used to." 


\section{APPENDIX I: CAL POLY AND SWANTON RESEARCH PROJECTS AND REPORTS INDEX}

Cal Poly has always required master's theses to be deposited to the Robert $\mathrm{E}$. Kennedy Library. Submission of senior projects to Robert E. Kennedy Library is based on departmental policies and is not required. Records of theses and senior projects that have been summited can be viewed though the Kennedy Library's catalog, PolyCat (http://polycat.lib.calpoly.edu/), however the search functionality does not provide full-text searching. Cal Poly's online institutional repository is the DigitalCommons@CalPoly. All master's theses have been deposited there since November 2008 and senior projects as of September 2009. A basic search at http://digitalcommons.calpoly.edu/help-search.html searches the full text of all documents posted. Publications that mention Swanton include theses, senior projects, faculty research papers, books, and more. However there are untold numbers of students, class, faculty and government research projects that have never been cataloged and/or lost on computer hard drives, on desks, in offices, and in the 'circular file.' The Table 4: Swanton Research List provides bibliographic information for research materials located by the author and is not inclusive of all research. 
Table 4: Swanton Research List. Exemplar list of research projects concerning and/or conducted at Swanton.

\begin{tabular}{|c|c|c|c|c|c|c|c|c|c|c|}
\hline $\begin{array}{l}\text { Aulhor Las } \\
\text { Name }\end{array}$ & $\begin{array}{l}\text { Aulhor Lasi } \\
\text { Nama (2) }\end{array}$ & $\begin{array}{l}\text { Author Last } \\
\text { Name (J) }\end{array}$ & $\begin{array}{l}\text { Aulho Las } \\
\text { Name (4) }\end{array}$ & Yeart & Tillo & Pages & Insiltution & Depariment & Type & $\begin{array}{c}\text { Locadion of } \\
\text { Item }\end{array}$ \\
\hline AbBdI & & & & 2005 & $\begin{array}{l}\text { Cal Poly Swanton } \\
\text { Paadlic Hauch Raunge } \\
\text { Pastute Assefssment }\end{array}$ & 20 & $\begin{array}{l}\text { Calpoly } \\
\text { (CAFES) }\end{array}$ & \begin{tabular}{|c|} 
Agriaullinal Bosiness \\
\end{tabular} & Report & $\begin{array}{l}\text { Swanton } \\
\text { Pacilic } \\
\text { Baugin }\end{array}$ \\
\hline Akers & & & & 2000 & $\begin{array}{l}\text { Longhtudnaliprolile and } \\
\text { Cros: Section Sivey on } \\
\text { Sevets Creek }\end{array}$ & $70-80$ & $\begin{array}{l}\text { Calpoly } \\
\text { (GAFES) }\end{array}$ & $\begin{array}{l}\text { Nalurai Rescurces } \\
\text { Management and } \\
\text { Enviromental }\end{array}$ & & 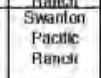 \\
\hline Ali & Codv & & & करण1 & 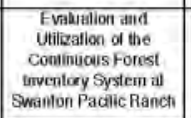 & 45 & $\begin{array}{l}\text { Call Poly } \\
\text { (CAFES) }\end{array}$ & $\begin{array}{l}\text { Nilural Resources } \\
\text { Management and } \\
\text { Envronmental } \\
\text { Sciences }\end{array}$ & $\begin{array}{l}\text { Senior } \\
\text { Propect }\end{array}$ & $\begin{array}{l}\text { Pobeel } \\
\text { Kennedv } \\
\text { Lurary }\end{array}$ \\
\hline When & & & & क्श? & $\begin{array}{l}\text { Swanton Padilic Rasuch } \\
\text { insed Colledion }\end{array}$ & & $\begin{array}{l}\text { Galpoly } \\
\text { (CAFES) }\end{array}$ & $\begin{array}{l}\text { Horticilture \& Crop } \\
\text { Solence }\end{array}$ & $\begin{array}{l}\text { Seniar } \\
\text { Project }\end{array}$ & \\
\hline Andersentin & Kelly & Piper & & काशी & $\begin{array}{c}\text { The Forest Hessources of } \\
\text { the Swamton Pactic } \\
\text { Panch }\end{array}$ & 34 & $\begin{array}{l}\text { CailPoly } \\
\text { (CAFES) }\end{array}$ & 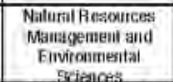 & & $\begin{array}{l}\text { Swanton } \\
\text { Pacili: } \\
\text { Raundi }\end{array}$ \\
\hline Anclesson & & & & 1994 & $\begin{array}{l}\text { Land Use Maps tor } \\
\text { Swanton Pactic Panch }\end{array}$ & & $\begin{array}{l}\text { Calpoly } \\
\text { (CAFEG) }\end{array}$ & $\begin{array}{l}\text { Nalual Resources } \\
\text { Management and } \\
\text { Enviromenesial }\end{array}$ & $\begin{array}{l}\text { Seniof } \\
\text { Projecl }\end{array}$ & \\
\hline Anderson & & & & 1994 & $\begin{array}{c}\text { The Land Use Mappling } \\
\text { of SWanton Padilic: } \\
\text { Paunch }\end{array}$ & 33 & $\begin{array}{l}\text { Galpoly } \\
\text { (EAFFf5) }\end{array}$ & 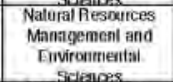 & $\begin{array}{l}\text { Sentor } \\
\text { Proioct }\end{array}$ & $\begin{array}{l}\text { Robect: } \\
\text { Kemenedy } \\
\text { tubrary }\end{array}$ \\
\hline Andrews & & & & 2012 & $\begin{array}{l}\text { Posi-fire Morlalliy and } \\
\text { Response in a } \\
\text { ReriweodDoughastit } \\
\text { Forest, Sama Cruz }\end{array}$ & 50 & $\begin{array}{l}\text { Calpoly } \\
\text { (EAHEli) }\end{array}$ & $\begin{array}{l}\text { Nalural hesources } \\
\text { Management and } \\
\text { Environumental } \\
\text { Scleaicos }\end{array}$ & Thesis & $\begin{array}{c}\text { Digloilcon } \\
\text { momsitealp } \\
\text { olyedil }\end{array}$ \\
\hline Auftein & & & & 1999 & $\begin{array}{l}\text { Soctits Groes Baseilne } \\
\text { and Grid System lot } \\
\text { swanton Padillc fanch }\end{array}$ & 16 & $\begin{array}{l}\text { Calpoly } \\
\text { (CAFrs) }\end{array}$ & 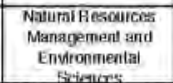 & Hepont & $\begin{array}{l}\text { Swanton } \\
\text { Parific } \\
\text { Ranch }\end{array}$ \\
\hline Anlen & & & & 2000 & 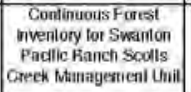 & 32 & $\begin{array}{l}\text { MalPoly } \\
\text { (CAFES) }\end{array}$ & $\begin{array}{l}\text { Nalural Resources } \\
\text { Managemenil and } \\
\text { Envronmental } \\
\text { Sciterces: }\end{array}$ & Hepar & $\begin{array}{l}\text { Swanton } \\
\text { Pachic } \\
\text { Ranci }\end{array}$ \\
\hline Autum & & & & 2012 & \begin{tabular}{|l|} 
Morallity Assessment of \\
Mecowood and Mixed \\
Coniler Forest Iypes in \\
Santa Cruz County \\
Followeng miditie
\end{tabular} & 715 & $\begin{array}{l}\text { CalPoly } \\
\text { (CAFES) }\end{array}$ & $\begin{array}{l}\text { Natural fiestources } \\
\text { Management and } \\
\text { Enviromental } \\
\text { Bciences }\end{array}$ & $\begin{array}{l}\text { Masterty } \\
\text { Thessis }\end{array}$ & $\begin{array}{c}\text { Dightulcexni } \\
\text { momsarcalp } \\
\text { olyedp }\end{array}$ \\
\hline Barton & & & & 1902 & $\begin{array}{c}\text { Coastal Wellands } \\
\text { Bequilition; Central } \\
\text { Calitornia Case Sludy } \\
\text { Sortu Gieak }\end{array}$ & 26 & UCSC & Imuronimental Studies & $\begin{array}{l}\text { Seniof } \\
\text { Thesh }\end{array}$ & $\begin{array}{l}\text { Sukanlon } \\
\text { Pacilk } \\
\text { Raucdi }\end{array}$ \\
\hline Bech & & & & 199021 & $\begin{array}{l}\text { Teral Hog Conlroflon the } \\
\text { Sutanton Pactic Rancti }\end{array}$ & 215 & $\begin{array}{l}\text { CalPoly } \\
\text { (CAFES) }\end{array}$ & $\begin{array}{l}\text { Honliaillure a crop } \\
\text { sclence }\end{array}$ & $\begin{array}{l}\text { Senior } \\
\text { Projecl }\end{array}$ & $\begin{array}{l}\text { RobertE } \\
\text { Kennedy } \\
\text { Libraty }\end{array}$ \\
\hline 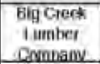 & & & & 1989 & 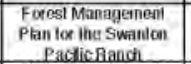 & & & $\mathrm{N} / \mathrm{A}$ & NIA & $\begin{array}{l}\text { Bobert E. } \\
\text { Kemedy } \\
\text { Librans }\end{array}$ \\
\hline Bishop & & & & 2006 & $\begin{array}{l}\text { Timbes Type Map lox } \\
\text { Swanton Pacilic: Pand: } \\
\text { Designed to Sirality } \\
\text { Continuous Forest } \\
\text { inventory Sample Dala }\end{array}$ & 10 & $\begin{array}{l}\text { Cilpoly } \\
\text { (CAFES) }\end{array}$ & $\begin{array}{l}\text { Natural fiesouices } \\
\text { Management and } \\
\text { Fnviromental } \\
\text { Sclences }\end{array}$ & Peport & $\begin{array}{l}\text { Swanton } \\
\text { Patialic: } \\
\text { Parsit }\end{array}$ \\
\hline Bishiop & & & & 2004 & 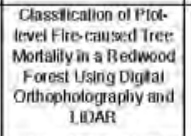 & का & $\begin{array}{l}\text { Calpoly } \\
\text { (CAFES) }\end{array}$ & $\begin{array}{l}\text { Natural Hesources } \\
\text { Mauagemenil and } \\
\text { Environmental } \\
\text { Sctesos }\end{array}$ & Thests & $\begin{array}{c}\text { Diginicom } \\
\text { monskidcalp } \\
\text { olvedu }\end{array}$ \\
\hline Botdieal & & & & 1894 & 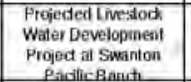 & TOT & $\begin{array}{l}\text { CalPoly } \\
\text { (CAFES) }\end{array}$ & Anitunil Sckence & $\begin{array}{l}\text { Seniot } \\
\text { Project }\end{array}$ & $\begin{array}{l}\text { Swanton } \\
\text { Pachic: } \\
\text { Ramas }\end{array}$ \\
\hline Fin:arty & & & & 9009 & $\begin{array}{l}\text { Antilysis of to Pinis } \\
\text { rodinte Seed Stock Field } \\
\text { Traal in the Nalive Ano } \\
\text { Nuevo Stand in }\end{array}$ & 121 & $\begin{array}{l}\text { GalPoly } \\
\text { (CAFES) }\end{array}$ & $\begin{array}{l}\text { Naiurtai fiedoinces: } \\
\text { Managemeni and } \\
\text { Environmenial } \\
\text { Sclences }\end{array}$ & Thestis & 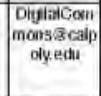 \\
\hline Brown & Tomincas: & & & 2009 & $\begin{array}{l}\text { Swanton Paclic Organic } \\
\text { Apple Orchard Soil } \\
\text { Surwoy Hepoti }\end{array}$ & & & & & $\begin{array}{l}\text { Swanton } \\
\text { Pacille } \\
\text { Huncti }\end{array}$ \\
\hline
\end{tabular}

\section{Page 1 of 11: Swanton Research List}




\begin{tabular}{|c|c|c|c|c|c|c|c|c|c|c|}
\hline Bulges & & & & 1929 & 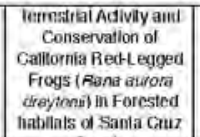 & $\mathbb{1 1 7}$ & & 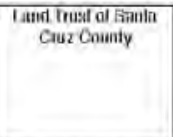 & tiepon & $\begin{array}{l}\text { Swinlon } \\
\text { Padtlc } \\
\text { fianch }\end{array}$ \\
\hline Burdili & Hoded & & & 1929 & \begin{tabular}{|c|} 
Wididile Population \\
Spollight Survey of \\
Swanton Pactic handr
\end{tabular} & -50 & $\begin{array}{l}\text { Calpoly } \\
\text { (CAAFES) }\end{array}$ & $\begin{array}{l}\text { Naturail hesoulces } \\
\text { Managernenil and } \\
\text { Enviroumental }\end{array}$ & $\begin{array}{l}\text { Senior } \\
\text { Project }\end{array}$ & \begin{tabular}{|l|} 
Swaniton \\
Parflic: \\
Panch
\end{tabular} \\
\hline Eutterworth & & & & 2013 & 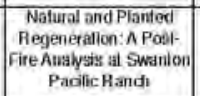 & 20 & $\begin{array}{l}\text { CalPely } \\
\text { (CAIIS) }\end{array}$ & $\begin{array}{l}\text { Natirathesoufoes } \\
\text { Management and } \\
\text { Enviroumental } \\
\text { Sctenices }\end{array}$ & $\begin{array}{l}\text { Sonkr } \\
\text { Projed }\end{array}$ & $\begin{array}{l}\text { Swaniton } \\
\text { Pacilic } \\
\text { Aauch }\end{array}$ \\
\hline Capps & & & & 1994 & \begin{tabular}{|l|} 
Teasbinity of Goats for \\
Brusti Control al \\
Swanton Pacilic Rasnch
\end{tabular} & & $\begin{array}{l}\text { GalPoly } \\
\text { (CAFES) }\end{array}$ & Agriailiural Business & $\begin{array}{l}\text { Senkor } \\
\text { Projed }\end{array}$ & \\
\hline Cardoza & Rubertson & Fालवien & Zuniwaili & 2006 & 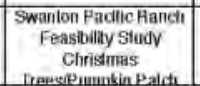 & 33 & $\begin{array}{l}\text { CalPoly } \\
\text { (CAFES) }\end{array}$ & Aglomilturil Business & Repon & \begin{tabular}{|l|} 
Swainlon \\
Pactlic \\
Manch
\end{tabular} \\
\hline Chum & & & & 1997 & $\begin{array}{c}\text { Design of Guest } \\
\text { Housing lor Swanton } \\
\text { Pacitio Ranch }\end{array}$ & & $\begin{array}{l}\text { Galpoly } \\
\text { (CANES) }\end{array}$ & $\begin{array}{l}\text { Biofesource and } \\
\text { Agricultural } \\
\text { Enoincring }\end{array}$ & $\begin{array}{l}\text { Seniot } \\
\text { Project }\end{array}$ & $\begin{array}{l}\text { Roberi E, } \\
\text { Kemedy } \\
\text { Chrumy }\end{array}$ \\
\hline Coe & & & & 1950 & \begin{tabular}{|l|} 
Rareand Endangered \\
Planis and anumbiss al \\
Swanton Padilic Banch
\end{tabular} & & $\begin{array}{l}\text { Calpoly } \\
\text { (CAFES) }\end{array}$ & $\begin{array}{l}\text { Natual Resouices } \\
\text { Management and } \\
\text { Environmental }\end{array}$ & $\begin{array}{l}\text { Seniof } \\
\text { Project }\end{array}$ & \\
\hline Colioon & & & & 1997 & Pine Plici Canker Study & 12 & $\begin{array}{l}\text { Calpoly } \\
\text { (CNFES) }\end{array}$ & $\begin{array}{l}\text { Nathualinesources } \\
\text { Munagement and } \\
\text { Environimential }\end{array}$ & $\begin{array}{l}\text { Spendal } \\
\text { Problem! }\end{array}$ & $\begin{array}{l}\text { Swanton } \\
\text { Pacille } \\
\text { Pancti }\end{array}$ \\
\hline Calgiller & & & & 2001 & 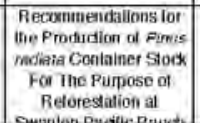 & & $\begin{array}{l}\text { Calpoly } \\
\text { (GAFfS) }\end{array}$ & $\begin{array}{l}\text { Nitural hesouirces } \\
\text { Management and } \\
\text { Envionimental } \\
\text { Scderios }\end{array}$ & $\begin{array}{l}\text { Seniwr } \\
\text { Projed }\end{array}$ & \begin{tabular}{|l|} 
Roberl E \\
Kenmerdy \\
I Ibrary
\end{tabular} \\
\hline Crathith & & & & रूान & \begin{tabular}{|c|} 
Evaliualing Five Years of \\
Soll Hydrologic \\
Response Following the \\
2009 Lodheed Fre in \\
the Coastal Santa Cuur \\
Mountains of Callomia
\end{tabular} & 516 & $\begin{array}{l}\text { GalPoly } \\
\text { (CAFES) }\end{array}$ & $\begin{array}{l}\text { Natural Hescuirces } \\
\text { Management and } \\
\text { Environmental } \\
\text { Sciencess }\end{array}$ & Thests & $\begin{array}{c}\text { Digitalcom } \\
\text { inons@calp } \\
\text { olyede }\end{array}$ \\
\hline Gross & & & & 2016 & \begin{tabular}{|l|} 
Stand E Pre-and Pos- \\
Itarvesi Data 1 Ille \\
Creek Drainage \\
Swantom Pacilic fiancti
\end{tabular} & 25 & $\begin{array}{l}\text { CalPody } \\
\text { (CAFFs) }\end{array}$ & $\begin{array}{l}\text { Natural Refueirces } \\
\text { Management and } \\
\text { Environmentai } \\
\text { Sclences }\end{array}$ & Repor & \begin{tabular}{|l|} 
Swanton \\
Prutlic \\
Rancti
\end{tabular} \\
\hline Craviser & & & & 1991 & 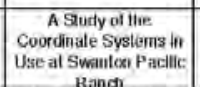 & & $\begin{array}{l}\text { Galpoty } \\
\text { (CAFES) }\end{array}$ & $\begin{array}{l}\text { Naturail Resoutces } \\
\text { Managoment and } \\
\text { Environmental }\end{array}$ & $\begin{array}{l}\text { Special } \\
\text { Probiem }\end{array}$ & \\
\hline Crow & & & & 2013 & $\begin{array}{c}\text { Testing Subspecies } \\
\text { Limils in Monardielar } \\
\text { Milose }\end{array}$ & 40 & Call foly (CSM) & $\begin{array}{l}\text { Sominos } \\
\text { Biwogjal Sdences }\end{array}$ & Thesis & 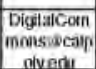 \\
\hline Guntis & & & & 2013 & $\begin{array}{l}\text { Forestry Meril Eadge at } \\
\text { Swanton Pudic Randi }\end{array}$ & 22 & $\begin{array}{l}\text { Calpoly } \\
\text { (CAFES) }\end{array}$ & $\begin{array}{l}\text { Natural Resources } \\
\text { Management and } \\
\text { Environenental } \\
\text { Solenes }\end{array}$ & $\begin{array}{l}\text { Sentor } \\
\text { Projed }\end{array}$ & \\
\hline Guzich & & & & 2001 & $\begin{array}{l}\text { The Swanton Pacilic } \\
\text { Aasudi Bangeland } \\
\text { Monitorng Proganm }\end{array}$ & 129 & $\begin{array}{l}\text { Galpoly } \\
\text { (CAFES) }\end{array}$ & $\begin{array}{l}\text { Natural Resouices } \\
\text { Management and } \\
\text { Envromimental }\end{array}$ & $\begin{array}{l}\text { Sentior } \\
\text { Projed }\end{array}$ & $\begin{array}{l}\text { Totient E. } \\
\text { Kenuedy } \\
\text { I thrary }\end{array}$ \\
\hline Dawe & मान & & & 1994 & \begin{tabular}{|c|} 
An Flemientery \\
Curricaum: Hodlisic \\
Resource Managemerit
\end{tabular} & & $\begin{array}{l}\text { CalPoly } \\
\text { (CAFtS) }\end{array}$ & Animal Sojence & $\begin{array}{l}\text { Senior } \\
\text { Pmiped }\end{array}$ & \\
\hline Dials & De्tlina & & & 2003 & \begin{tabular}{|c|} 
A Comparison of \\
Gallomla Forest \\
Pradtice Rules and Two \\
Forest Certilicalions
\end{tabular} & 67 & calpoly & & Repont & 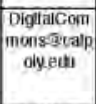 \\
\hline Diras: & & & & 2000 & 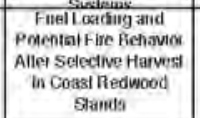 & 3 & त्वांस्णly & & Hepori & $\begin{array}{l}\text { bigililicomi } \\
\text { inonswetaip } \\
\text { olyedi }\end{array}$ \\
\hline
\end{tabular}

\section{Page 2 of 11: Swanton Research List}




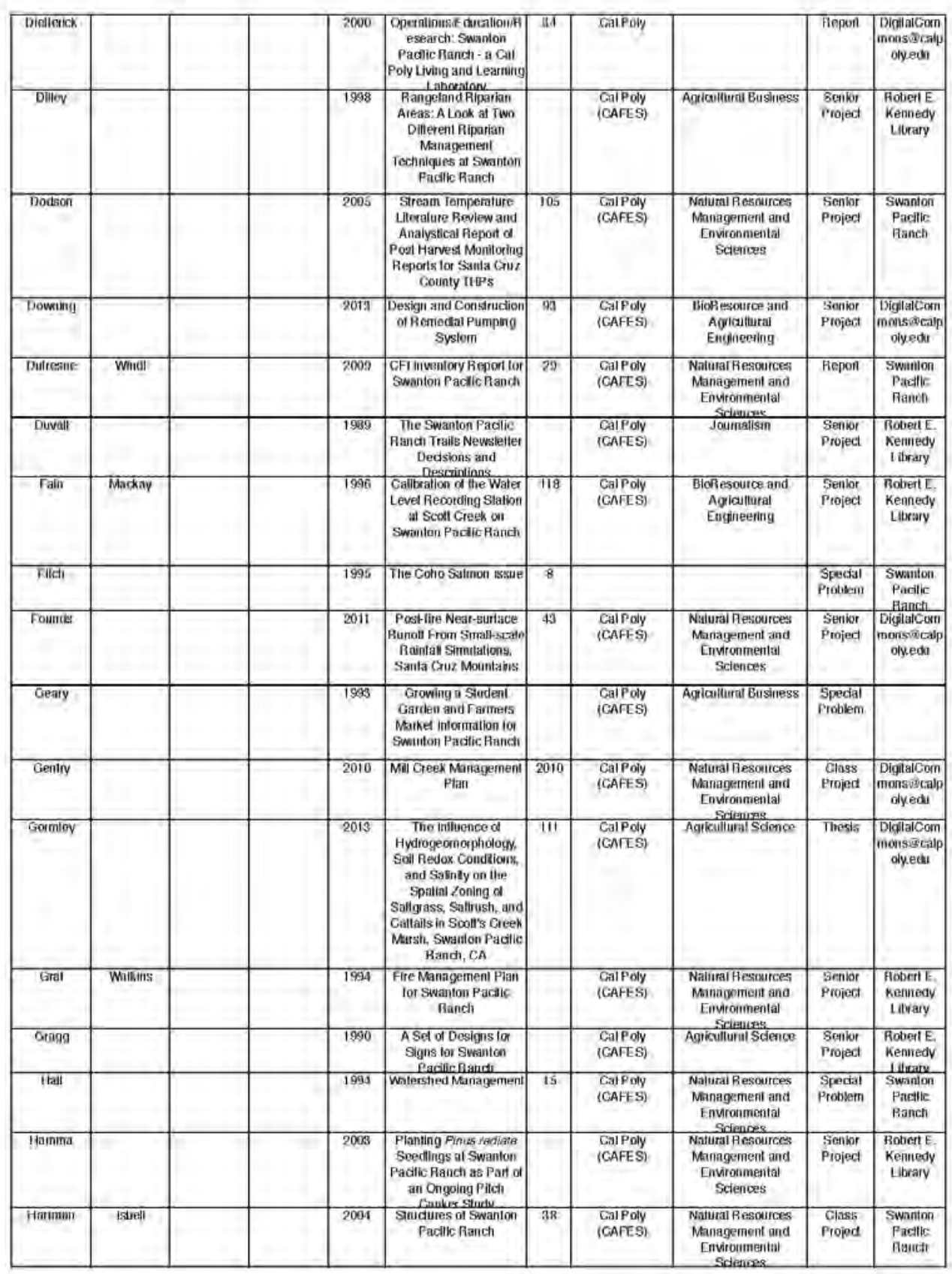

Page 3 of 11: Swanton Research List 


\begin{tabular}{|c|c|c|c|c|c|c|c|c|c|c|}
\hline Hasham & & & & 1924 & $\begin{array}{l}\text { Selling tinibes in Saula } \\
\text { Cuuz County }\end{array}$ & & $\begin{array}{l}\text { CalPobly } \\
\text { (CAFES) }\end{array}$ & 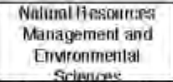 & $\begin{array}{l}\text { Prankir } \\
\text { Proped }\end{array}$ & $\begin{array}{l}\text { Fobort E } \\
\text { Keniedy } \\
\text { Litraty }\end{array}$ \\
\hline Hess & & & & 2008 & $\begin{array}{c}\text { Chaticalerizalion of Litie } \\
\text { Creek Trbulates T1 and } \\
\text { I2 al Swanton Pacdic } \\
\text { Aandi }\end{array}$ & 65 & $\begin{array}{l}\text { Calpoiy } \\
\text { (CAFES; }\end{array}$ & $\begin{array}{l}\text { Naturalinesoutces } \\
\text { Mamagemeni andi } \\
\text { Envirenimental } \\
\text { Seiences }\end{array}$ & & $\begin{array}{l}\text { Swanton } \\
\text { Puatlic: } \\
\text { Panch }\end{array}$ \\
\hline Hauph & & & & 2006 & 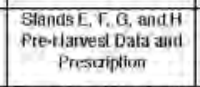 & -80 & $\begin{array}{l}\text { Calpoly } \\
\text { (CAFES) }\end{array}$ & 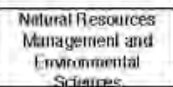 & $\begin{array}{l}\text { Senior } \\
\text { Projed }\end{array}$ & $\begin{array}{l}\text { Swantor } \\
\text { Pactlic } \\
\text { Planch }\end{array}$ \\
\hline Haves & & & & 1999 & $\begin{array}{c}\text { Fomation of The Scrits } \\
\text { Greet Witersied } \\
\text { Coumcil }\end{array}$ & 81 & & & $\begin{array}{l}\text { Case } \\
\text { Gludy }\end{array}$ & $\begin{array}{l}\text { Swanion } \\
\text { Paclic } \\
\text { Baunth }\end{array}$ \\
\hline $\begin{array}{l}\text { Henrofr- } \\
\text { Potana }\end{array}$ & & & & 1993 & $\begin{array}{c}\text { Growing into the } \\
\text { Emvironment - } \\
\text { Elesnentary Cumicalum }\end{array}$ & & $\begin{array}{l}\text { Galpoly } \\
\text { (CARES) }\end{array}$ & Agriailural Sdences & $\begin{array}{l}\text { Senkor } \\
\text { Propecil }\end{array}$ & $\begin{array}{l}\text { Tobeet L } \\
\text { Keninedy } \\
\text { Lubrary }\end{array}$ \\
\hline Hillbunn & & & & 2010 & 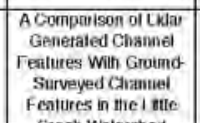 & 115 & $\begin{array}{l}\text { CalPoly } \\
\text { (CAFES) }\end{array}$ & $\begin{array}{l}\text { Nalural Resoutces } \\
\text { Management and } \\
\text { Envionmenlal } \\
\text { Sciencoss }\end{array}$ & Thess & $\begin{array}{c}\text { Digitalcom } \\
\text { inonsigealp } \\
\text { ofyeun }\end{array}$ \\
\hline Howe्l & & & & 2009 & 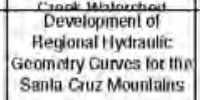 & 53 & $\begin{array}{l}\text { Calpoly } \\
\text { (CAFES) }\end{array}$ & $\begin{array}{l}\text { Nolural Resources } \\
\text { Mauagement andi } \\
\text { Envionminntal } \\
\text { Sclences }\end{array}$ & $\begin{array}{l}\text { Senior } \\
\text { Project }\end{array}$ & $\begin{array}{l}\text { Swainton } \\
\text { Pautlic } \\
\text { Bonch }\end{array}$ \\
\hline Tloif & Robinsoit & & & 1993 & 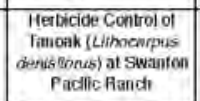 & & $\begin{array}{l}\text { Calpoly } \\
\text { (CAFFS) }\end{array}$ & $\begin{array}{l}\text { Nolural Resoutces } \\
\text { Management and } \\
\text { Envronmontal } \\
\text { Sclences }\end{array}$ & $\begin{array}{l}\text { Senior } \\
\text { Project }\end{array}$ & $\begin{array}{l}\text { Robert E. } \\
\text { Kennedy } \\
\text { I thrary }\end{array}$ \\
\hline kracsson- & & & & 2012 & \begin{tabular}{|c|} 
Capturing History From \\
the Cal Poly Cotege of \\
Agriculture, Food and \\
EnMronmental Sactors \\
Since 1950
\end{tabular} & 37 & $\begin{array}{l}\text { Calpoly } \\
\text { (GAFEs) }\end{array}$ & Agriouttural sdencs: & $\begin{array}{l}\text { Senhor } \\
\text { Project }\end{array}$ & $\begin{array}{l}\text { Thoberi E } \\
\text { Kermedy } \\
\text { Libraly }\end{array}$ \\
\hline Jacobson: & Dikus & & & 2003 & 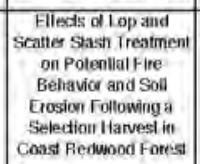 & 7 & ल्न्वाएक्षणy & & Heport & $\begin{array}{c}\text { Dighlaiconi } \\
\text { inonsarcaip } \\
\text { olyean }\end{array}$ \\
\hline Jami & & & & 1994 & Timber Harvesting Pan & & Galpoly & $\begin{array}{l}\text { NaluralResoutces } \\
\text { Managemenl and } \\
\text { Enyronmental } \\
\text { Sclences }\end{array}$ & & $\begin{array}{l}\text { Roben } E \\
\text { Kenmedy } \\
\text { itfrary }\end{array}$ \\
\hline Jaworski & & & & 1992 & \begin{tabular}{|c|} 
stratoge Doworming \\
Program on Bred \\
Heilers, Swanton Pantic \\
Raurch
\end{tabular} & & $\begin{array}{l}\text { GalPoly } \\
\text { (CAFES) }\end{array}$ & Animal Scisence & $\begin{array}{l}\text { Senlor } \\
\text { Project }\end{array}$ & $\begin{array}{l}\text { Robert E } \\
\text { Kemedy } \\
\text { Library }\end{array}$ \\
\hline Jeflery & & & & 1996 & 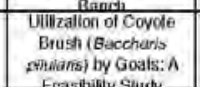 & 26 & $\begin{array}{l}\text { Meltoutne } \\
\text { Oniversily }\end{array}$ & $\begin{array}{l}\text { Aggicullure and } \\
\text { Horticulture }\end{array}$ & Repori & $\begin{array}{l}\text { Swarifion } \\
\text { Pacilic } \\
\text { Raucti }\end{array}$ \\
\hline Johinson & & & & 1994 & $\begin{array}{c}\text { Bewevaluation of } \\
\text { Bangeland Monitorng at } \\
\text { Swanlon Pactic Rancti }\end{array}$ & & $\begin{array}{l}\text { CalPoly } \\
\text { (CAFES) }\end{array}$ & $\begin{array}{l}\text { Nalural Resoutcen } \\
\text { Management and } \\
\text { Environmental }\end{array}$ & $\begin{array}{l}\text { Sellivt } \\
\text { Project }\end{array}$ & \\
\hline Kelly & & & & 1904 & \begin{tabular}{c|} 
Dwersinging Crops at \\
Swanion Padtic Pancti: \\
Sweect Com
\end{tabular} & & $\begin{array}{l}\text { Galpoly } \\
\text { (CAFES) }\end{array}$ & $\begin{array}{l}\text { Hotticulture a Gop } \\
\text { Science }\end{array}$ & $\begin{array}{l}\text { Seniot } \\
\text { Project }\end{array}$ & \\
\hline Kieldsen & Chiscensen & & & 19022 & $\begin{array}{l}\text { The Swanton Pacilic } \\
\text { Experiences (Video) }\end{array}$ & & $\begin{array}{l}\text { CallPoly } \\
\text { (CAFES) }\end{array}$ & $\begin{array}{l}\text { Nalural Resources } \\
\text { Managennent fand } \\
\text { Environmental }\end{array}$ & $\begin{array}{l}\text { Seniot } \\
\text { Project }\end{array}$ & $\begin{array}{l}\text { Robett } \\
\text { Kemedy } \\
\text { It thraly }\end{array}$ \\
\hline Kosky & & & & 1998 & 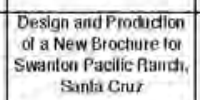 & 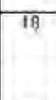 & GarlPoly (CUA) & $\begin{array}{c}\text { Sciranges } \\
\text { Graphic } \\
\text { Commenticalions }\end{array}$ & $\begin{array}{l}\text { Senlor } \\
\text { Projed }\end{array}$ & $\begin{array}{l}\text { DobertL, } \\
\text { Kennedy } \\
\text { Library }\end{array}$ \\
\hline Lacdle & & & & 1988 & $\begin{array}{c}\text { Geographic inlorination } \\
\text { Systems Applications tor } \\
\text { the Swanton Pacalc: } \\
\text { Bancli }\end{array}$ & 68 & $\begin{array}{l}\text { Galpoly } \\
\text { (GAFES) }\end{array}$ & $\begin{array}{l}\text { Nainali hesources } \\
\text { Marmagement and } \\
\text { Environumental } \\
\text { Sicienons }\end{array}$ & $\begin{array}{l}\text { Senibr } \\
\text { Project }\end{array}$ & $\begin{array}{l}\text { Thoberit } \\
\text { Kemmedy } \\
\text { Library }\end{array}$ \\
\hline
\end{tabular}

\section{Page 4 of 11: Swanton Research List}




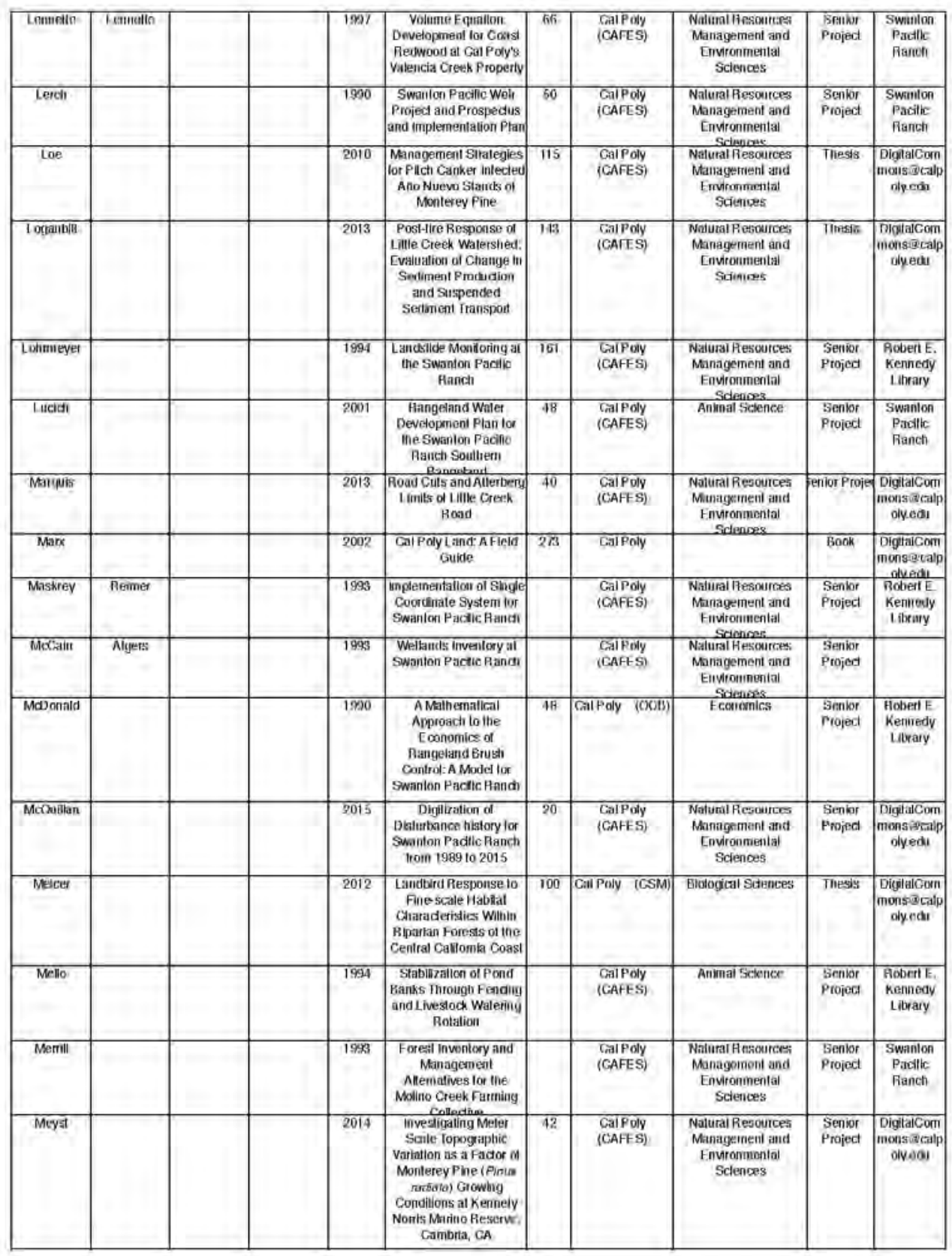

Page 5 of 11: Swanton Research List 


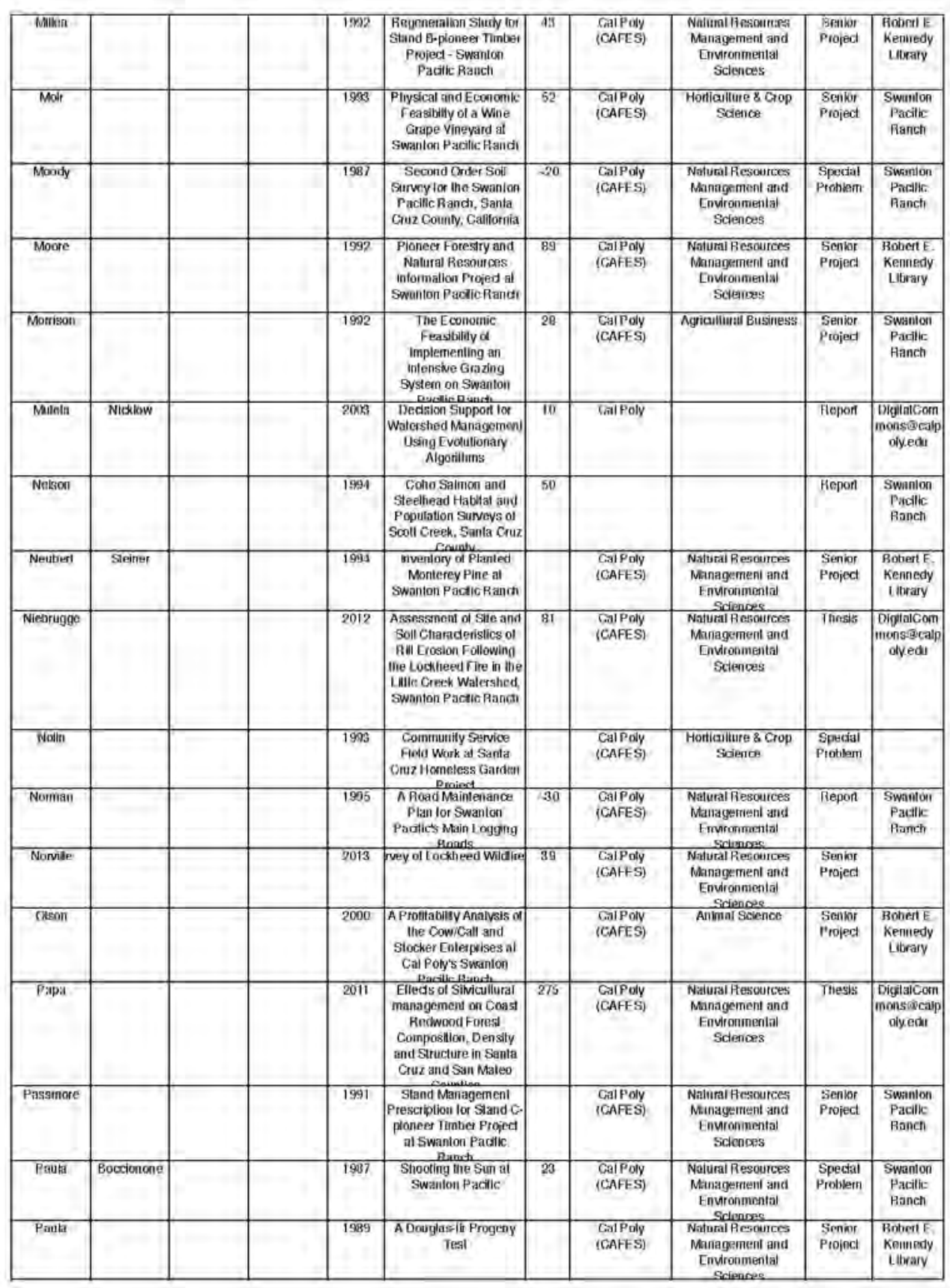

\section{Page 6 of 11: Swanton Research List}




\begin{tabular}{|c|c|c|c|c|c|c|c|c|c|c|}
\hline Pandios & & & & 2012 & 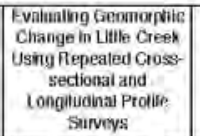 & 382 & $\begin{array}{l}\text { CalPoly } \\
\text { (CAFES) }\end{array}$ & 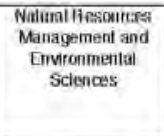 & Thertis & \begin{tabular}{|c|} 
DiallalCom \\
innossibatip \\
olyedon
\end{tabular} \\
\hline Perty & & & & 2014 & \begin{tabular}{|c|} 
Project Proposal and \\
Devetopmenl Plan for a \\
New Security Gale al \\
Swanton Pacilic Rancti
\end{tabular} & 42 & $\begin{array}{l}\text { Calpoiy } \\
\text { (CAFES) }\end{array}$ & Agikantunat Science & $\begin{array}{l}\text { Senior } \\
\text { Project }\end{array}$ & $\begin{array}{c}\text { Digitalcon } \\
\text { monsuscalp } \\
\text { olyedu }\end{array}$ \\
\hline Piluto & S्ञnk: & All & Aulten & 2005 & \begin{tabular}{|c|} 
USing FORSEE and \\
Contlinuons Forest \\
inventory intormation to \\
Evaluale Implementalion \\
ol Uneven-aged \\
Mainagement in Santa \\
Cruz County Const \\
Fedwood Forests
\end{tabular} & 18 & Galpoly & & Bepont & $\begin{array}{c}\text { Digitalcom } \\
\text { monsiscalp } \\
\text { olyedi }\end{array}$ \\
\hline Filino & Smith & HIIII & fobtenson & 1996 & 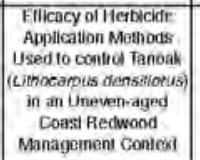 & 11 & TSIDA & & Heport & \begin{tabular}{|c|} 
Digilitcom \\
monswecalp \\
ofyedi
\end{tabular} \\
\hline relimo & Yaสkenta! & & & 2003 & \begin{tabular}{c|} 
Sirudure and \\
Development al Pildi \\
Canker intected \\
Moneterey Pine Stamiss \\
ai Ano Nuevo, Callornia
\end{tabular} & 15 & Galpoly & & Teport & \begin{tabular}{|c|} 
Digitaicam \\
monsaysalp \\
olyedis
\end{tabular} \\
\hline Pराinto & Ttiompson & Piper & & 2000 & \begin{tabular}{|c|} 
implementing finevent \\
aged Feowood \\
Management at Cal \\
Poly's School Forest, an
\end{tabular} & 15 & Galpoly & & Report & \begin{tabular}{|c|} 
Diggraicom \\
monseguatp \\
otyeds
\end{tabular} \\
\hline Pimential & & & & 1994 & 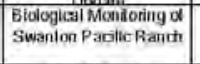 & & $\begin{array}{l}\text { Galpoly } \\
\text { (CAfFS) }\end{array}$ & Antumil sosence & $\begin{array}{l}\text { Senior } \\
\text { Projed }\end{array}$ & $\begin{array}{l}\text { Roberi E. } \\
\text { Kerimedy } \\
\text { L thraty }\end{array}$ \\
\hline Plinkentint & & & & 2006 & 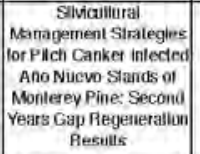 & & $\begin{array}{l}\text { Galpoly } \\
\text { (GAFFS) }\end{array}$ & 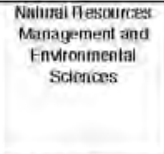 & Thessis & $\begin{array}{l}\text { RoberlE } \\
\text { Kecomemly } \\
\text { L Ibenty }\end{array}$ \\
\hline Plper & Kently & Anthasesi & & 1900 & $\begin{array}{c}\text { The Foresi Hesoumces if } \\
\text { the Swanion Padilic } \\
\text { Ranch }\end{array}$ & 32 & $\begin{array}{l}\text { Galpoly } \\
\text { (CAFES) }\end{array}$ & $\begin{array}{l}\text { Nalural Fescuitces } \\
\text { Management and } \\
\text { Environmentital }\end{array}$ & $\begin{array}{l}\text { Sraniar } \\
\text { Projed }\end{array}$ & $\begin{array}{l}\text { Hoberl E } \\
\text { Kenivedy } \\
\text { Luraty }\end{array}$ \\
\hline Plpes & Pirfo & & & 1990 & \begin{tabular}{|c|} 
Stand Management \\
Presciplion lot Stand B \\
at Swanton Padilc
\end{tabular} & 30 & $\begin{array}{l}\text { GilPoly } \\
\text { (CAFES) }\end{array}$ & $\begin{array}{l}\text { Natural Restources } \\
\text { Management and } \\
\text { Environmental }\end{array}$ & $\begin{array}{l}\text { Spedal } \\
\text { Problem }\end{array}$ & $\begin{array}{l}\text { Swanton } \\
\text { Pacilic } \\
\text { Fanch }\end{array}$ \\
\hline Poland & & & & 1996 & $\begin{array}{l}\text { Stand E Pre and Post } \\
\text { Harvest Data. Ullte } \\
\text { Creek Drainage, } \\
\text { Swanlon Parilic Aanch }\end{array}$ & 20 & $\begin{array}{l}\text { Galpoly } \\
\text { (GArtS) }\end{array}$ & 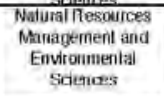 & Theport & $\begin{array}{l}\text { Robert E, } \\
\text { Kenmedy } \\
\text { Library }\end{array}$ \\
\hline Pope & Moal & Smitin & & 1982 & 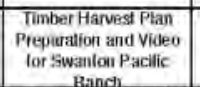 & & $\begin{array}{l}\text { CalPoty } \\
\text { (CAIES) }\end{array}$ & 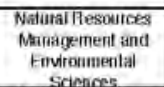 & $\begin{array}{l}\text { Senbr } \\
\text { Projed }\end{array}$ & \\
\hline 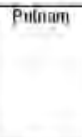 & & & & 1924 & 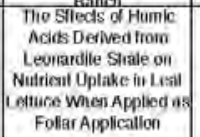 & & $\begin{array}{l}\text { CalPoly } \\
\text { (CAFES) }\end{array}$ & $\begin{array}{l}\text { Horllailluer \&Gop } \\
\text { Sclence }\end{array}$ & $\begin{array}{l}\text { Sentor } \\
\text { Propect }\end{array}$ & $\begin{array}{l}\text { Robell E } \\
\text { Kennedy } \\
\text { Library }\end{array}$ \\
\hline Bice & Hovanitz & & & 1929 & \begin{tabular}{|c|} 
The Saga of the Overlait \\
Rallway Padilics: Fromi \\
Panana to Poty
\end{tabular} & & & & Book & $\begin{array}{l}\text { Robetl E } \\
\text { Kenmedy } \\
\text { Library }\end{array}$ \\
\hline Sadder & & & & $\mathrm{N} / \mathrm{A}$ & \begin{tabular}{c|} 
A Survey ol the \\
Complismoe of the Normi \\
Fork Itarvest
\end{tabular} & $\sqrt{12}$ & $\begin{array}{l}\text { CalPdy } \\
\text { (GAFES) }\end{array}$ & 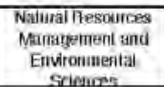 & $\begin{array}{l}\text { Senlar } \\
\text { Projed }\end{array}$ & $\begin{array}{l}\text { Swanton } \\
\text { Postle } \\
\text { Bancth }\end{array}$ \\
\hline Salo & & & & 1995 & $\begin{array}{c}\text { A Survey of the } \\
\text { Buildings on the } \\
\text { Swanton Pactic Hanch }\end{array}$ & 26 & Calpoly & & Tleport & $\begin{array}{l}\text { Swanilon } \\
\text { Partlic } \\
\text { Hanch }\end{array}$ \\
\hline
\end{tabular}

Page 7 of 11: Swanton Research List 


\begin{tabular}{|c|c|c|c|c|c|c|c|c|c|}
\hline Saller : & & & 2006 & 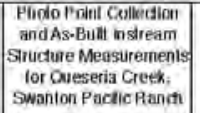 & 161 & $\begin{array}{l}\text { CalPoly } \\
\text { (CAFES) }\end{array}$ & 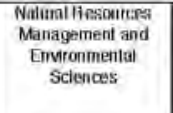 & $\begin{array}{l}\text { Praniar } \\
\text { Projed }\end{array}$ & $\begin{array}{l}\text { Fobont le } \\
\text { Kemedy } \\
\text { Loraty }\end{array}$ \\
\hline Santord & & & 2009 & \begin{tabular}{|c|} 
Delemining Acouracy of \\
Canopy Cover Densily \\
Using a Densitometor
\end{tabular} & 27 & $\begin{array}{l}\text { Cal Poly } \\
\text { (CAAFES) }\end{array}$ & $\begin{array}{l}\text { Natural iesoutices } \\
\text { Managemenil and } \\
\text { Environimental }\end{array}$ & Report & $\begin{array}{l}\text { Swaniton } \\
\text { Paratic: } \\
\text { Panch }\end{array}$ \\
\hline Sarn & & & 1993 & 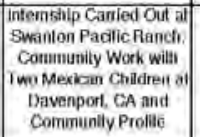 & 14 & $\begin{array}{l}\text { CalPoly } \\
\text { (CAITS) }\end{array}$ & $\begin{array}{l}\text { NatiralResouroes } \\
\text { Management and } \\
\text { Enviromimental } \\
\text { Scitennes }\end{array}$ & Bepont & \\
\hline Sinn & & & 1993 & 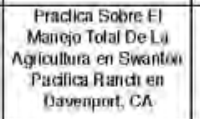 & & $\begin{array}{l}\text { CalPoly } \\
\text { (CAFES) }\end{array}$ & $\begin{array}{l}\text { Nalural frescurces } \\
\text { Managemeni and } \\
\text { Enviromental } \\
\text { Sclentess }\end{array}$ & Thesti: & \\
\hline focogiamillo & & & 1980 & $\begin{array}{c}\text { Evatuation and } \\
\text { umplementalion of } \\
\text { Uheven-aget forest } \\
\text { Managentent al } \\
\text { Swanton Paclic Planch }\end{array}$ & 69 & $\begin{array}{l}\text { Calpoly } \\
\text { (CAFES) }\end{array}$ & $\begin{array}{l}\text { Natural Resources } \\
\text { Management and } \\
\text { Envirummenial } \\
\text { Sciences }\end{array}$ & $\begin{array}{l}\text { Seniot } \\
\text { Project }\end{array}$ & $\begin{array}{l}\text { Swamion } \\
\text { Puthle } \\
\text { Banich }\end{array}$ \\
\hline Sicrudato & & & श्रा० & 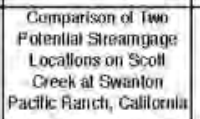 & 414 & $\begin{array}{l}\text { GalPoly } \\
\text { (CAFES) }\end{array}$ & $\begin{array}{l}\text { Natirai Pesuitces } \\
\text { Management and } \\
\text { Endroumental } \\
\text { Sclences }\end{array}$ & Thesis & $\begin{array}{c}\text { Digitalcom } \\
\text { munsoycalp } \\
\text { olvedy }\end{array}$ \\
\hline Seetey & & & 1995 & 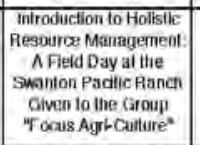 & -40 & $\begin{array}{l}\text { CalPoly } \\
\text { (GNFES) }\end{array}$ & Agriauthan Edence & $\begin{array}{l}\text { Senior } \\
\text { Projed }\end{array}$ & $\begin{array}{l}\text { Swanton } \\
\text { Pustlc } \\
\text { Bancti }\end{array}$ \\
\hline 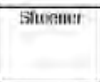 & Parket & Soderiumd & 2002 & \begin{tabular}{c|} 
Water and Lake \\
Protedbn Zone lor Lutie \\
Greek Harvest
\end{tabular} & 20 & $\begin{array}{l}\text { CalPoly } \\
\text { (CAFES) }\end{array}$ & $\begin{array}{l}\text { Nalimal Rescoutcis: } \\
\text { Management and } \\
\text { Emvronmental }\end{array}$ & Tiepon & $\begin{array}{l}\text { Swinton } \\
\text { Padilc } \\
\text { Panch }\end{array}$ \\
\hline Simmikrol & & & 8007 & 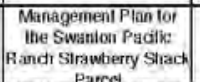 & & $\begin{array}{l}\text { Galpoily } \\
\text { (CAFES) }\end{array}$ & Animal Scrence & $\begin{array}{l}\text { Senior } \\
\text { Project }\end{array}$ & $\begin{array}{l}\text { Robetic } \\
\text { Kentuedy } \\
\text { titraty }\end{array}$ \\
\hline 9mith & & & 1992 & 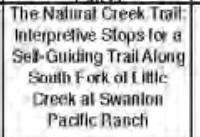 & 25 & $\begin{array}{l}\text { GalPoly } \\
\text { (GATSS) }\end{array}$ & $\begin{array}{l}\text { Naturalnesouncess } \\
\text { Management and } \\
\text { Enviromimentai } \\
\text { Sidenors }\end{array}$ & $\begin{array}{l}\text { Senlor } \\
\text { Project }\end{array}$ & $\begin{array}{l}\text { Thobert L, } \\
\text { Kennedy } \\
\text { Library }\end{array}$ \\
\hline Smith & & & 2002 & $\begin{array}{l}\text { Chlome Medicinal Uses } \\
\end{array}$ & 19 & UCSC & & t1eport & \\
\hline Grilth & & & 2011 & 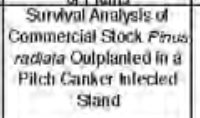 & 66 & $\begin{array}{l}\text { CalPoly } \\
\text { (GAFES) }\end{array}$ & $\begin{array}{l}\text { Nalual Rescutcos } \\
\text { Management and } \\
\text { Envrommental } \\
\text { Scienx:s }\end{array}$ & Thess & $\begin{array}{c}\text { Digitalcom } \\
\text { mons@ealp } \\
\text { olyedo }\end{array}$ \\
\hline Soderitumd & Korm & & 2001 & \begin{tabular}{l|} 
Hazard Alder Survey of \\
Scolli: Creek Walershed \\
Swanton Pacilic Rania, \\
Sanla Guz Counly; CA
\end{tabular} & & $\begin{array}{l}\text { CalPoly } \\
\text { (CAFFS) }\end{array}$ & $\begin{array}{l}\text { Naturai Resources } \\
\text { Management and } \\
\text { Enuronmental } \\
\text { Sclences }\end{array}$ & $\begin{array}{l}\text { Senior } \\
\text { Project }\end{array}$ & $\begin{array}{l}\text { Robert E. } \\
\text { Kennedy } \\
\text { Library }\end{array}$ \\
\hline Sleen & हाता & & 1987 & \begin{tabular}{|c|} 
Swanton Padilo Ranch \\
Stady and \\
Recsomeneudations:
\end{tabular} & -100 & & & Report & \begin{tabular}{|c|} 
Swanion \\
Praclic \\
Plancti
\end{tabular} \\
\hline Stephens & Prito & Catamagne & 2004 & $\begin{array}{l}\text { Tre Pregines and } \\
\text { Resultant Foress } \\
\text { Siruclure in the Nalive } \\
\text { Ano Nuevo Montcrity } \\
\text { Pinn (Pinis radiasa) }\end{array}$ & 12 & Calpoly & & Tieport & $\begin{array}{l}\text { Digitaicom } \\
\text { monsigcalp } \\
\text { olyedı }\end{array}$ \\
\hline slevian & & & 2001 & 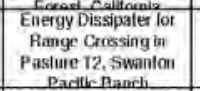 & 27 & $\begin{array}{l}\text { Calpoly } \\
\text { (CAFES) }\end{array}$ & 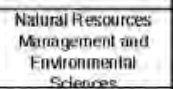 & Feport & $\begin{array}{l}\text { Swauton } \\
\text { Pacilic } \\
\text { flanch }\end{array}$ \\
\hline stone & & & 2000 & $\begin{array}{c}\text { Prolltablity of Grassies } \\
\text { Beet Callle }\end{array}$ & 47 & $\begin{array}{l}\text { CalPoly } \\
\text { (CAFES) }\end{array}$ & Agriaultural Bussiness & $\begin{array}{l}\text { Senibr } \\
\text { Project }\end{array}$ & $\begin{array}{l}\text { Swanion } \\
\text { Pacilic } \\
\text { Banch } \\
\end{array}$ \\
\hline
\end{tabular}

Page 8 of 11: Swanton Research List 


\begin{tabular}{|c|c|c|c|c|c|c|c|c|c|}
\hline Fintlent & & & 1922 & $\begin{array}{l}\text { Lillie Cronk Flume } \\
\text { Proged lor Swanton } \\
\text { Pacilic Ranct }\end{array}$ & & $\begin{array}{l}\text { CalPobly } \\
\text { (CAFES) }\end{array}$ & 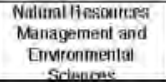 & $\begin{array}{l}\text { Franior } \\
\text { Project }\end{array}$ & $\begin{array}{l}\text { Fobetil E } \\
\text { Kennedy } \\
\text { Library }\end{array}$ \\
\hline Surleet & Shangset & Dietlerich & 8012 & 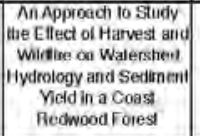 & 8 & Calpoly & & Report & \begin{tabular}{|c|} 
Digitalcon \\
monswicalp \\
olyedo
\end{tabular} \\
\hline $\begin{array}{l}\text { Tallitisch- } \\
\text { Edson }\end{array}$ & & & 1002 & \begin{tabular}{c|} 
The Uitte Creek \\
Walershed Trail Buide, a \\
Sell-guided Truil al \\
Swanlon Padic Ranch
\end{tabular} & 21 & $\begin{array}{l}\text { GalPody } \\
\text { (GAIIS) }\end{array}$ & $\begin{array}{l}\text { Notural Resoupoes } \\
\text { Management and } \\
\text { Envionimental } \\
\text { Scitenoss }\end{array}$ & $\begin{array}{l}\text { Senkor } \\
\text { Project }\end{array}$ & $\begin{array}{l}\text { Swonton } \\
\text { Pacilic } \\
\text { Aauch }\end{array}$ \\
\hline Tappeto & & & 1595 & $\begin{array}{c}\text { Reforestation Evaluastion } \\
\text { of SAand } x^{\prime} \text { al Smanton } \\
\text { Paticic Ranch }\end{array}$ & 92 & $\begin{array}{l}\text { Galpoly } \\
\text { (CAIES) }\end{array}$ & $\begin{array}{l}\text { Natural Resources } \\
\text { Managernent and } \\
\text { Enviroumential }\end{array}$ & $\begin{array}{l}\text { Senkor } \\
\text { Profect }\end{array}$ & $\begin{array}{l}\text { Robet L, } \\
\text { Keninedy } \\
\text { Library }\end{array}$ \\
\hline Tatum & & & 1995 & \begin{tabular}{c|} 
Swanton Padilic Hancti \\
Student Garden and \\
Garden Manual
\end{tabular} & 27 & $\begin{array}{l}\text { CalPoly } \\
\text { (CAFES) }\end{array}$ & Agricullual Sugen & $\begin{array}{l}\text { Senlor } \\
\text { Projedt }\end{array}$ & $\begin{array}{l}\text { KobeflE, } \\
\text { Kenuedy } \\
\text { Library }\end{array}$ \\
\hline Theobald & & & 2014 & \begin{tabular}{|c|} 
Eyaluation of Red Addet \\
Mortility in live Lillie \\
Greck Watersiced \\
Following the 2005 \\
Lockheed Fire
\end{tabular} & 73 & $\begin{array}{l}\text { Galpoly } \\
\text { (CAFES) }\end{array}$ & $\begin{array}{l}\text { Natural Resources } \\
\text { Management and } \\
\text { Envirunmenilat } \\
\text { Scienres }\end{array}$ & Thesis & \begin{tabular}{|c|} 
Digitalcom \\
mons@ealp \\
olyedn
\end{tabular} \\
\hline Thompsan & करच्या & & 1996 & \begin{tabular}{|c|} 
Pre-farves Sand \\
Analysis and Stalisilical \\
Evaluation of the Fores \\
Resouirces of Swanton \\
Pacilic Aanuti
\end{tabular} & & $\begin{array}{l}\text { GalPoly } \\
\text { (CAFES) }\end{array}$ & $\begin{array}{l}\text { Nadinai Pesuitces } \\
\text { Muinagement and } \\
\text { Endronomental } \\
\text { Sclences }\end{array}$ & $\begin{array}{l}\text { Senior } \\
\text { Project }\end{array}$ & $\begin{array}{l}\text { Rotient E- } \\
\text { Keninedy } \\
\text { Lthrary }\end{array}$ \\
\hline Thompsen & Dikus & & 2005 & 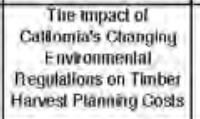 & 40 & Galpoly & & Meport & $\begin{array}{l}\text { Digilicom } \\
\text { movsocosip } \\
\text { oly.edi }\end{array}$ \\
\hline Thompson & Dkas & & 2004 & 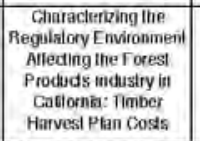 & 57 & CalPoly & & Hepon & $\begin{array}{c}\text { Digilalchot } \\
\text { innonsiscalp } \\
\text { olyeden }\end{array}$ \\
\hline Inlligkent & & & 2012 & \begin{tabular}{c|} 
The Spattal Distitiution \\
of K-lador Values \\
Across a Toposequenoe \\
and a Soll Survey Map
\end{tabular} & 34 & $\begin{array}{l}\text { CalPoly } \\
\text { (CAAFES) }\end{array}$ & Agriculturatsomor & The्s: & $\begin{array}{c}\text { Digrtalcom } \\
\text { monsusicalp } \\
\text { olyedu }\end{array}$ \\
\hline Timinouts & & & 1993 & $\begin{array}{c}\text { Preservang the Strudurai } \\
\text { History ol Swanton } \\
\text { Pacitic Ranch }\end{array}$ & & $\begin{array}{l}\text { GiPoly } \\
\text { (CAFES) }\end{array}$ & Animal Sevence & $\begin{array}{l}\text { Senlat } \\
\text { Project }\end{array}$ & $\begin{array}{l}\text { Robert E, } \\
\text { Kenmedy } \\
\text { Library }\end{array}$ \\
\hline Tiumonts & & & 1999 & 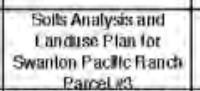 & 53 & $\begin{array}{l}\text { Cal Poly } \\
\text { (CAFES) }\end{array}$ & $\begin{array}{l}\text { Nelural Hescurces: } \\
\text { Managenent and } \\
\text { Environimental } \\
\text { Sideriges }\end{array}$ & Heport & $\begin{array}{l}\text { Swanton } \\
\text { Pactic: } \\
\text { Aanch }\end{array}$ \\
\hline Tिणता & & & 1988 & $\begin{array}{l}\text { Pegelntive Iype Map For } \\
\text { Siwanton Pacilic Randi }\end{array}$ & 22 & $\begin{array}{l}\text { CalPoly } \\
\text { (CAFES) }\end{array}$ & $\begin{array}{l}\text { Natual Rescestices } \\
\text { Management and } \\
\text { Environmental }\end{array}$ & $\begin{array}{l}\text { Senilor } \\
\text { Projedt }\end{array}$ & $\begin{array}{l}\text { Foberle, } \\
\text { Kenuedy } \\
\text { Library }\end{array}$ \\
\hline Tomincass & frown & & 2009 & \begin{tabular}{|c|} 
Swanton Pacilic Ranch \\
Apple Ordiard Soil \\
Survey Heport
\end{tabular} & 30 & $\begin{array}{l}\text { GalPoly } \\
\text { (CAFES) }\end{array}$ & 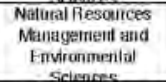 & Repont & $\begin{array}{l}\text { Swamton } \\
\text { Pucilic } \\
\text { Panch }\end{array}$ \\
\hline Tranmer & & & 2002 & \begin{tabular}{|c|} 
Conlinuous Foresi \\
Invesilory lor Cal Polys \\
Valencia Creek Property
\end{tabular} & 35 & $\begin{array}{l}\text { Cal Poly } \\
\text { (CAFES) }\end{array}$ & $\begin{array}{l}\text { Naltiral Resairces } \\
\text { Minagemenil and } \\
\text { Environuental } \\
\text { Solmogrs }\end{array}$ & Report & $\begin{array}{l}\text { Swamon } \\
\text { Pactic } \\
\text { Plancti }\end{array}$ \\
\hline Weddige & & & N/A & $\begin{array}{l}\text { Trall Rouling Options } \\
\text { From Staub House to } \\
\text { t llitic Greck Flumes }\end{array}$ & 15 & $?$ & & $\begin{array}{l}\text { Senikr } \\
\text { Projed }\end{array}$ & $\begin{array}{l}\text { Swanton } \\
\text { Parilic } \\
\text { Hinnch } \\
\text { Hen }\end{array}$ \\
\hline Wetimun & Westina & & 1995 & \begin{tabular}{c|} 
Evalualion and \\
Coastrudion of a Wates \\
Level Hecordang Stalican: \\
Swanton Pactic Randa
\end{tabular} & & $\begin{array}{l}\text { Galpoly } \\
\text { (CAFfS) }\end{array}$ & $\begin{array}{l}\text { Biofiesoutce und } \\
\text { Agriultarat } \\
\text { trigneering }\end{array}$ & $\begin{array}{l}\text { Seniwr } \\
\text { Projed }\end{array}$ & 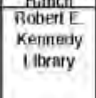 \\
\hline
\end{tabular}

\section{Page 9 of 11: Swanton Research List}




\begin{tabular}{|c|c|c|c|c|c|c|c|c|c|c|}
\hline Writta: & & & & $2(009)$ & 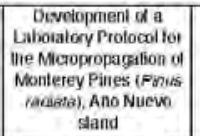 & 61 & $\begin{array}{l}\text { Galpoly } \\
\text { (CAFES) }\end{array}$ & $\begin{array}{l}\text { Nalunalliescouturs } \\
\text { Management and } \\
\text { Eirvironmental } \\
\text { Sciences }\end{array}$ & Theriti & \begin{tabular}{|c|} 
DidilalCoon \\
innossibatip \\
ofyedon
\end{tabular} \\
\hline While & Dielleric & Masiin. & Stohiman & 2010 & $\begin{array}{l}\text { Foresi Roads Mapped } \\
\text { Using LDAR in Slerep } \\
\text { Fotesled Terrat }\end{array}$ & 22 & Calpoly & & Repont & \begin{tabular}{|c|} 
Digitalcom \\
monsivicalp \\
olvedi
\end{tabular} \\
\hline Whitr & & & & 9010 & \begin{tabular}{|c|} 
Accaracy of Forest Poad \\
and Esiream Channel \\
Chiaraderistics Detived \\
Itom LiDAR in Forested \\
Mounitain Condilions
\end{tabular} & 130 & $\begin{array}{l}\text { CalPoly } \\
\text { (CAFIES) }\end{array}$ & $\begin{array}{l}\text { Natural Regouitces } \\
\text { Management and } \\
\text { Envirommentat } \\
\text { Sciences }\end{array}$ & Thersis & $\begin{array}{c}\text { Digitalcom } \\
\text { monachralp } \\
\text { olyedi }\end{array}$ \\
\hline Wilied & & & & 2012 & Vatencia GIS Projed & 24 & $\begin{array}{l}\text { CalPoly } \\
\text { (CAFES) }\end{array}$ & 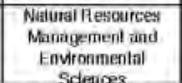 & $\begin{array}{l}\text { Sentior } \\
\text { Projed }\end{array}$ & $\begin{array}{l}\text { Swhniton } \\
\text { Parilic } \\
\text { Hanch }\end{array}$ \\
\hline Whillow & & & & 1993 & \begin{tabular}{|c|} 
Davenporf Communily \\
Database of Ghilareats \\
Adivilles: A Guide to \\
Successtully Grealing \\
Regular Adivilies lor ine \\
Youlth of Davenport
\end{tabular} & & $\begin{array}{l}\text { CalPoly } \\
\text { (CAFES) }\end{array}$ & Agricullural Scdence & $\begin{array}{l}\text { Sentor } \\
\text { Proiogt }\end{array}$ & $\begin{array}{l}\text { Aobert E: } \\
\text { Konnedy } \\
\text { Lituary }\end{array}$ \\
\hline Wichig & Johimson & Tomincasar & & 2010 & 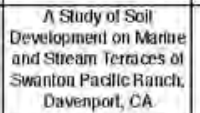 & 40 & $\begin{array}{l}\text { Galpoly } \\
\text { (CAFES) }\end{array}$ & $\begin{array}{l}\text { Notural Resources } \\
\text { Minagement and } \\
\text { Enurominental } \\
\text { Sclondes }\end{array}$ & $\begin{array}{l}\text { Sentior } \\
\text { Project }\end{array}$ & $\begin{array}{c}\text { Rotienl E } \\
\text { Kentiedy } \\
\text { I inrary }\end{array}$ \\
\hline Wiegers: & & & & 2007 & $\begin{array}{l}\text { Re-inesalute of Putol } \\
\text { Canker and Monterey } \\
\text { Pine Managemeni } \\
\text { Study, Swanton Pacilio }\end{array}$ & & $\begin{array}{l}\text { CalPoly } \\
\text { (CAFFS) }\end{array}$ & $\begin{array}{l}\text { Nalurai Besouirces } \\
\text { Management and } \\
\text { Environmental } \\
\text { Sdiqnos }\end{array}$ & $\begin{array}{l}\text { Senver } \\
\text { Projed }\end{array}$ & $\begin{array}{l}\text { Bobent E, } \\
\text { Kennedy } \\
\text { I Ibrary }\end{array}$ \\
\hline Wise & & & & 2004 & 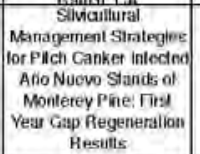 & & $\begin{array}{l}\text { Calpoly } \\
\text { (CAFES) }\end{array}$ & $\begin{array}{l}\text { Naiturai lestourcess } \\
\text { Management and } \\
\text { Fnvionmenial } \\
\text { Sciences }\end{array}$ & Thests & $\begin{array}{l}\text { Roberi E. } \\
\text { Keninedy } \\
\text { I Ibraty }\end{array}$ \\
\hline Wilinait & & & & 2012 & $\begin{array}{c}\text { Soll Mapping on a } \\
\text { Swanton Padilic Planch } \\
\text { Alangetand }\end{array}$ & 66 & $\begin{array}{l}\text { Gilpoly } \\
\text { (CAFES) }\end{array}$ & $\begin{array}{l}\text { Nolural Resources } \\
\text { Management and } \\
\text { Envronmental } \\
\text { Sclingout }\end{array}$ & $\begin{array}{l}\text { Scrifor } \\
\text { Projed }\end{array}$ & $\begin{array}{l}\text { Foberl E } \\
\text { Kennedy } \\
\text { Uurary }\end{array}$ \\
\hline Wondergem & Zenich & & & 2011 & 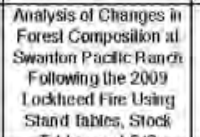 & 36 & $\begin{array}{l}\text { Calpoly } \\
\text { (CAFES) }\end{array}$ & 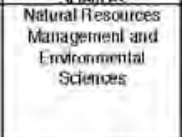 & $\begin{array}{l}\text { Senior } \\
\text { Project }\end{array}$ & \\
\hline Yates & & & & 2005 & $\begin{array}{c}\text { Oueseria Greek } \\
\text { Agricullutal Equipment } \\
\text { Bridge Dessign for } \\
\text { Swanlon Pacilic Panch }\end{array}$ & 67 & $\begin{array}{c}\text { GalPoly } \\
\text { (GENGICATES) }\end{array}$ & 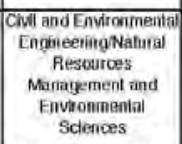 & $\begin{array}{l}\text { Senkor } \\
\text { Profecl }\end{array}$ & $\begin{array}{l}\text { Swaniton } \\
\text { Pacilic } \\
\text { Bancti }\end{array}$ \\
\hline nim & & & & 2011 & 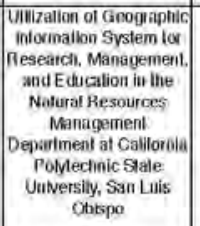 & 99 & $\begin{array}{l}\text { CalPoly } \\
\text { (CATLS) }\end{array}$ & $\begin{array}{l}\text { Naitual Resoutcs: } \\
\text { Management and } \\
\text { Envionmentol } \\
\text { Sciencess }\end{array}$ & $\begin{array}{c}\text { Class } \\
\text { Proped }\end{array}$ & \begin{tabular}{|c|} 
D) igitilcom \\
inonswicalp \\
ofyedi
\end{tabular} \\
\hline Shyder & & & & 1995 & \begin{tabular}{c|} 
Dendroctironologgcal \\
Sindy ot Coast fiedwoon \\
in Lilte Greek Drainage, \\
Fire Hesfory
\end{tabular} & 22 & $\begin{array}{l}\text { GalPoly } \\
\text { (CAFFS })\end{array}$ & $\begin{array}{l}\text { Nalurai Besources } \\
\text { Management and } \\
\text { Fnvironmental } \\
\text { Sclences }\end{array}$ & $\begin{array}{l}\text { Senior } \\
\text { Projerd }\end{array}$ & $\begin{array}{l}\text { Robert E, } \\
\text { Kermedy } \\
\text { I thrary }\end{array}$ \\
\hline stietd & & & & 1998 & $\begin{array}{l}\text { Sland Managyement } \\
\text { Pressiption lor the } \\
\text { Scolls Creck Stand }\end{array}$ & 15 & $\begin{array}{l}\text { Calpoly } \\
\text { (CAFES) }\end{array}$ & $\begin{array}{l}\text { Naidural Hescourcess } \\
\text { Management and } \\
\text { Environmental } \\
\text { Sclegeses }\end{array}$ & $\begin{array}{l}\text { Senior } \\
\text { Projed }\end{array}$ & $\begin{array}{l}\text { Roberi E: } \\
\text { Kerinedy } \\
\text { I thraty }\end{array}$ \\
\hline
\end{tabular}

Page 10 of 11: Swanton Research List 


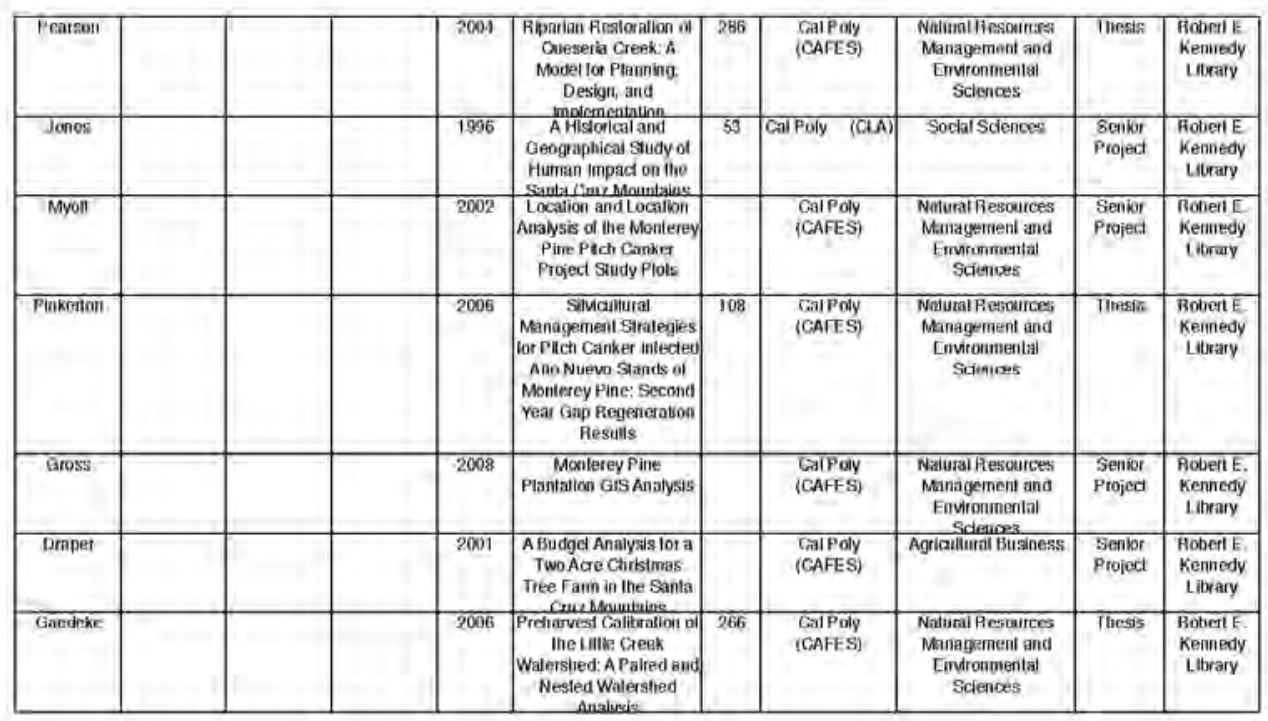

Page 11 of 11: Swanton Research List 
APPENDIX J: SWANTON 3 MILES

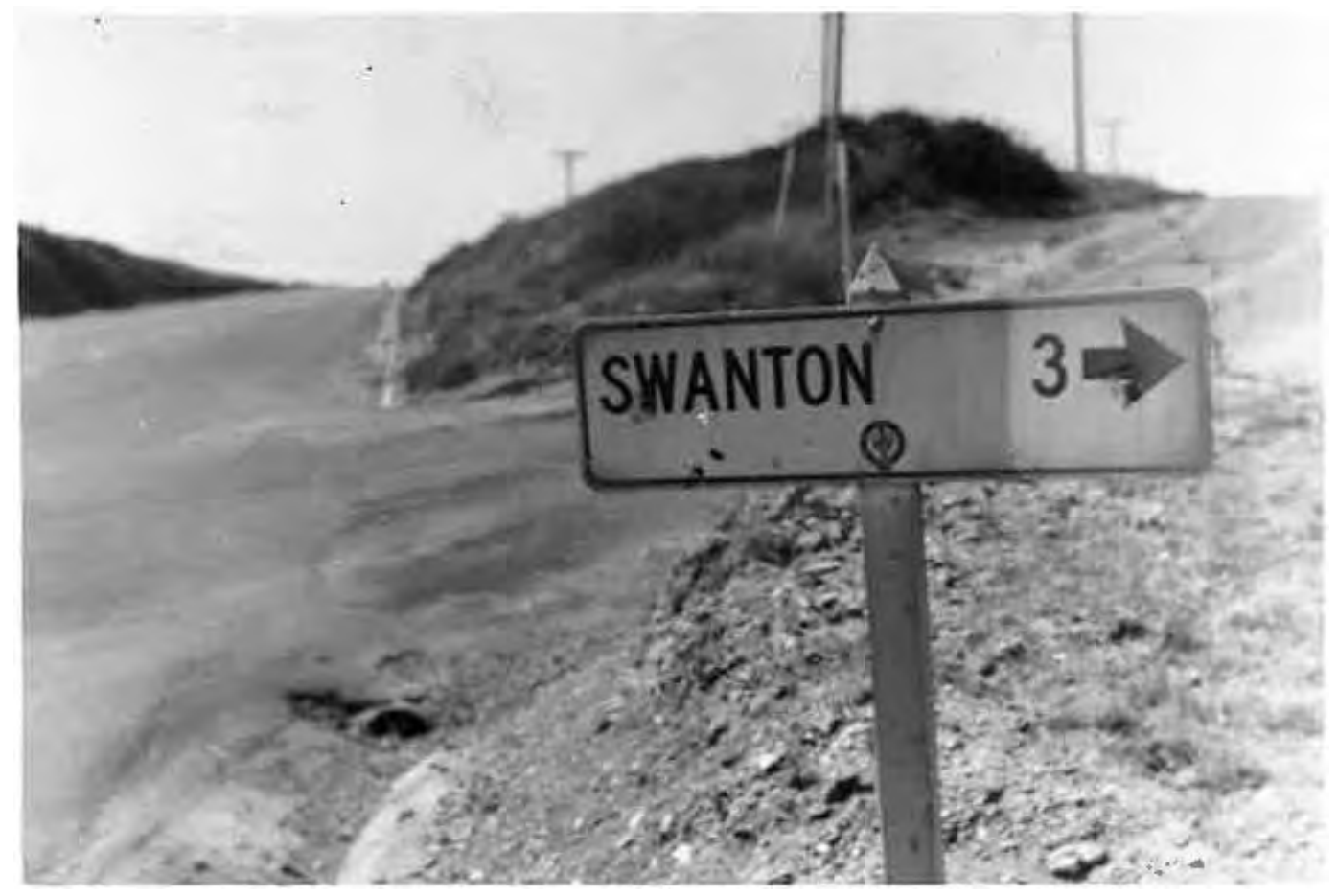

Figure 46: Postcard 1962. Courtesy Cal Poly Corporation, Swanton Pacific Railroad Society Collection. 